DAIRY FARMING

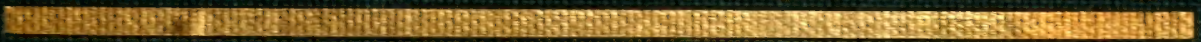

MICHELS 


$$
\text { (5) }
$$


5 




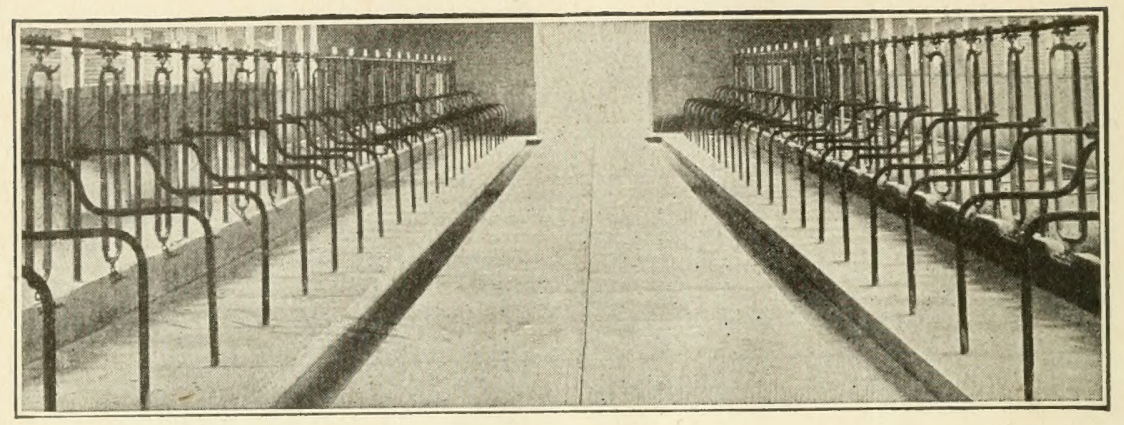

Interior of N. C. College and Station Dairy Barn, Designed by the Author.

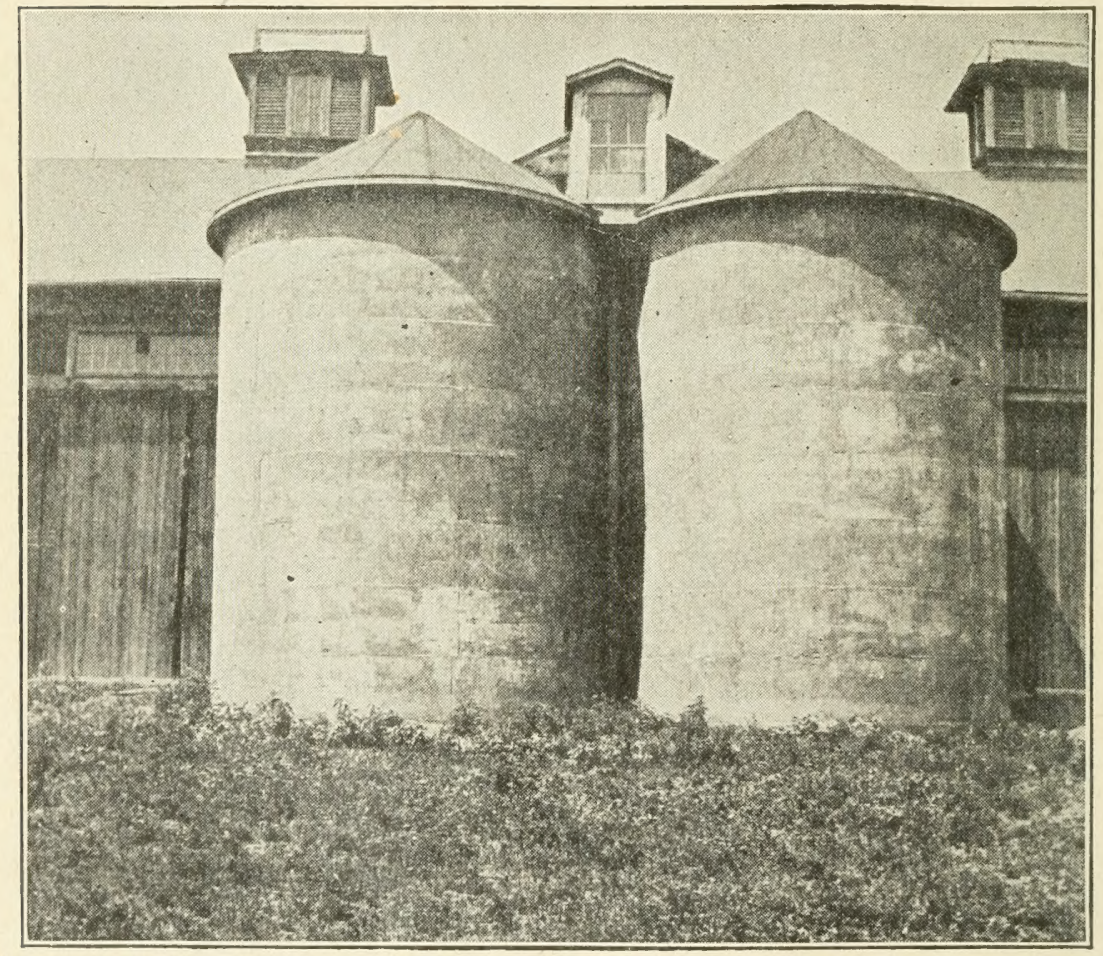

Twin Concrete Silos on "Michels' Stock Farm." 


\title{
Dairy Farming
}

BY

\author{
JOHN MICHELS, B. S. A., M. S.
}

Editor: "Butter, Cheese \& Egg Journal" and "The Milk Dealer." Author and Publisher of "Creamery Buttermaking" and "Market Dairying." Formerly Professor of Dairying and Animal Husbandry in the North Carolina State College of Agriculture.

\section{THIRD EDITION, REVISED}

\section{ILLUSTRATED}

MILWAUKEE, WISCONSIN

Published by the Author

1911

All Rights Reserved 


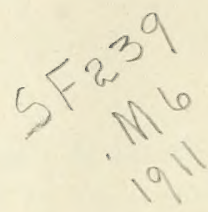

COPYRIGHT, BY

JOHN MICHELS

I907 and I9I I
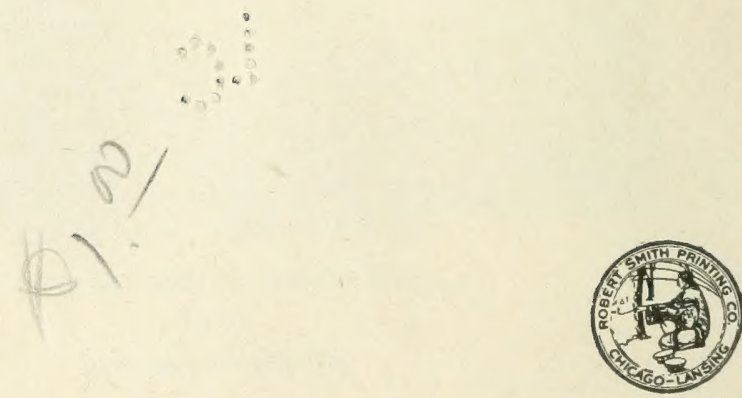

C G.A305211

$\mid(b: 1$ 


\section{PREFACE TO THIRD EDITION.}

In the preparation of this work, the endeavor has been to arrange in a concise and systematic form the essential facts relating to the science ard practice of dairy farming. It embodies the Author's twenty years' experience, both as a practical dairyman and as a student and teacher of dairy husbandry. Technical terms have been avoided as far as possible, in order that the book may not only meet the needs of the class-room, but also serve as a convenient and useful handbook for farmers not versed in the sciences.

In preparing the third edition of Dairy Farming, a thorough revision has been made of the entire book and about one hundred pages of new matter added. The addition of the large amount of important new matter should materially increase the usefulness of the book.

The general adoption of the book as a text and reference book in American Dairy Schools and the warm reception that has been generally accorded it, naturally has been a source of much satisfaction to the author and has prompted him more than ever to leave nothing undone in the present revision to make the book worthy of the confidence in which it is being held. 



\section{TABLE OF CONTENTS.}

PART I. THE DAIRY HERD.

Page.

Chapter

Chapter

Chapter

Chapter

Chapter

Chapter

Chapter

Chapter

Chapter

Chapter

Chapter

Chapter

Chapter

Chapter

Chapter

Chapter

Chapter

Chapter

Chapter

Chapter

Chapter

Chapter

Chapter

Chapter

Chapter

Chapter

Chapter

Chapter
I. Dairy Farming a Profitable Business... 7

II. Evolution of the Dairy Cow......... 9

III. Selection of Dairy Cows.......... I I

IV. Selection of Dairy Sires........... I7

V. Building Up a Dairy Herd......... 20

VI. Breeds of Dairy Cattle............ 25

VII. Feeding the Dairy Cow............ 33

VIII. Silos and Silage ............. 52

IX. Method of Keeping Herd Records..... . 60

X. Milking ..................... 68

XI. Herd Management .............. 73

XII. Rearing the Dairy Calf...........82

XIII. Dairy Barn .................. 86

XIV. Handling Farm Manure............ Iо

XV. Power on the Farm................

XVI. Diseases and Ailments of Dairy Cattle.. rIo

PART II. MILK AND ITS PRODUCTS.

XVII. Milk

I 23

XVIII. The Babcock Test ............... I35

XIX. Bacteria and Milk Fermentations...... I46

XX. Sanitary Milk Production............ I55

XXI. Farm Butter-Making ............. 65

XXII. Farm Cheese-Making ............. 87

XXIII. Starters .................... I93

XXIV. Soft and Fancy Cheese-Making........ I99

XXV. Cooling and Aeration of Milk and Cream .....................205

XXVI. How to Secure a Good Market........213

XXVII. Marketing Milk and Cream..........2I7

XXVIII. Ice Cream Making..............228 
Page.

Chapter XXIX. Skímmilk-Buttermilk .............233

Chapter XXX. Certified Milk ..................236

Chapter XXXI. Relative Market Value of Milk and Its Products ....................239

PART III. SUPPLEMENT.

Chapter XXXII. Valuing Dairy Stock..............244

Chapter XXXIII. Legumes (Alfalfa and Clovers).......253

Chapter XXXIV. The Dairy House ..............256

Chapter XXXV. Washing and Sterilizing Milk Vessels..263

Chapter XXXVI. Keeping Accounts ...............269

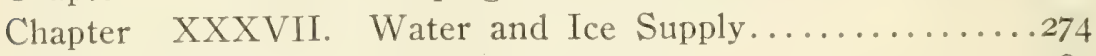

Chapter XXXVIII. Dairy By-Products ..............280

Chapter XXXIX. Machine Milking ...............282

Chapter XL. Pasteurization of Milk and Cream....284

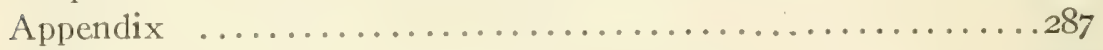

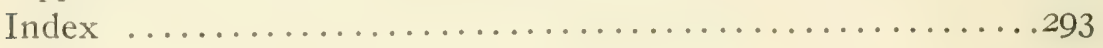




\section{PART I. \\ THE DAIRY HERD.}

\section{CHAPTER I.}

DAIRY FARMIING A PROFITABLE BUSINESS.

That dairy farming is a profitable business is fully attested by its unprecedented growth during the past decade and a half. No other branch of agriculture has ever witnessed such rapid development in a similar period of time. Its growth has not been confined to any particular section or sections of the country, but has been noticeable in all sections.

The profits that have prompted this rapid and general expansion of the dairy business have been deriver from two sources: ( I) direct profits realized from the sale of milk, cream, butter and cheese; (2) indirect profits accruing from an increased fertility of the land and the consequent increased productiveness of the same.

Direct Profits. It is pretty well conceded that in general dairy cows yield greater returns for feed consumed than either swine, sheep or beef animals. A good cow will yield not less than 300 pounds of butter a year, which, at 25 cents per pound, is worth $\$ 75$. Adding to this the value of 6,000 pounds of skim milk at 20 cents per IoO, 
and $\$$ IO as the value of the calf, we have a total income of $\$ 97$ a year. Subtracting from this $\$ 50$ as the average cost of the feed, we have $\$ 47$ remaining to pay for the labor and interest on investments.

Where good milk and cream markets are available the income from the sale of milk and cream may be actually double that from butter at 25 cents per pound. Moreover, with cows of a higher productive capacity than that here considered, the profits would be more than proportionally increased.

Indirect Profits. The marvelous growth of the dairy industry has in part been necessitated by the need of conserving and increasing the fertility of lands that have been cultivated without due regard to maintaining soil fertility. The selling of raw products from the farm, such as hay and grains, has been a constant source of soil impoverishment. This method of robbing the soil of its natural plant food has made farming in many of the New England and Southern States well nigh impossible without the aid of commercial fertilizers. In some of these states as much as $\$ 7,000,000$ is expended annually for these fertilizing materials.

By feeding the raw materials of the farm to dairy cows, we are not only manufacturing high priced products as compared with the value of the raw material, but we are retaining upon the farm that valuable by-product, the manure, which contains about $75 \%$ of the fertilizing constituents originally present in the feed. IVhere only butter is sold, practically all of the fertilizing ingredients of the feed are recovered, since butter contains scarceiy any fertilizing material. Even where cream is sold about $95 \%$ of the fertilizing value of the feed is retained upon the farm. 


\section{CHAP'TER II.}

\section{EVOLUTION OF THE DAIRY COW.}

The dairy cow is one of the most useful as well as one of the most profitable of all our domestic animals. Her products not only supply an indispensable want in the human dietary, but they are also the source of much profit to her owner.

Comparing the modern cow with her primitive ancestors a most interesting and instructive evolution in her milk giving function is noted. In the wild or primitive state her milk production was confined to a short period following parturition and was barely sufficient for the support of the calf. In her present form the amount of milk necessary for the support of the calf constitutes but a small part of her total possible production and its secretion is almost incessant.

Like the race horse, the dairy cow has been bred and handled for a specific purpose for a number of centuries. Continued specialization has resulted not only in an enormous increase of milk and butterfat production, but as a result of such increased production there has been created a specific conformation known as the dairy type.

At no period in the development of the dairy cow have such great strides been made as in the past half a century. Indeed, the period of general and systematic improvement in the common stock may be said to date from the invention of the Babcock test. Fifteen years ago the average butter production was approximately 125 pounds 
per cow. To-day the average production appoximates I75 pounds per cow.

There are hundreds of herds scattered over the country that average 300 pounds of butter per cow and many herds exceed even the 400 pound mark. Scores of individual cows could be mentioned that have reached the 600 and 700 pound mark, and the world's champion cow holds the phenomenal record of an even I, Ooo pounds of butter in one year.

Among the factors that have been instrumental in bringing about the remarkable evolution in the milk producing function of the cow, the following are the most important: (I) selection, or breeding only from the best milkers; (2) liberal and judicious feeding; (3) proper milking; (4) suitable environment, including conditions as to housing and sanitation; ( 5 ) good care and management. These factors will always continue the most important in the improvement of our modern herds, and will be discussed in the chapters which follow. 


\section{CHAPTER III.}

\section{SELEC'TION OF COWS.}

Success in dairying depends in a large measure upon one's ability to select the right animals in starting and building up the herd. Unless adapted by nature for dairy purposes, cows will remain unprofitable in spite of the best feed and management. The first lesson the dairyman has to learn, therefore, is to know how to discriminate between good cows and poor cows. The cardinal points to consider in the selection of a cow are: ( I) butterfat production; (2) type; (3) purity of breeding; (4) pedigree; and (5) health.

\section{BUT'TEREA'T PRODUCTION.}

The best guide in the selection of cows is the actual butterfat record as determined by a pair of scales and a Babcock tester. It is not enough to simply know the quantity of milk yielded by a cow; one must also know its fat content, for it is this that measures the value of milk for commercial uses as well as for butter and cheese production.

The method of determining the butterfat production of cows is treated in detail in chapter IX.

\section{CONFORMATION OR TYPE.}

All dairy experts recognize a definite type as associated with economical milk production. The judge in the show ring bases his judgment entirely upon type or con- 
formation. While there still may be differences of opinion among breeders as to minor points, these are really of little consequence. The points that go to make up the ideal type will be treated under six heads: (I) dairy temperament; (2) feeding capacity; (3) constitution; (4) milk organs; (5) quality; and (6) pelvic region.

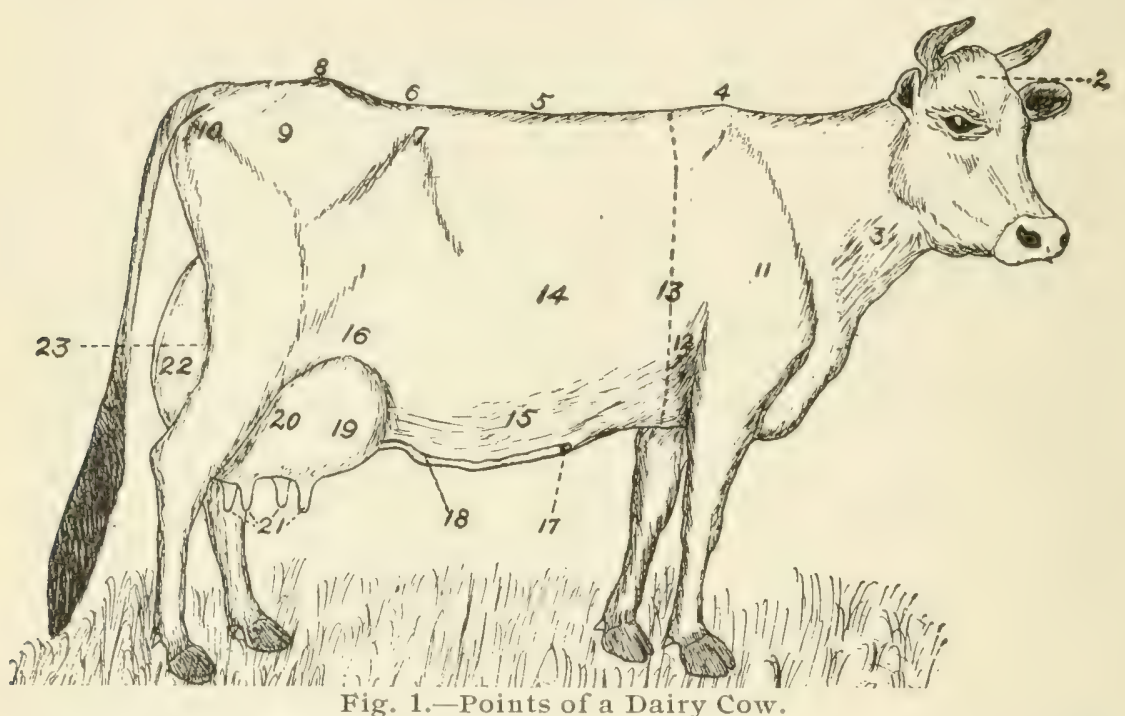

1. Muzzle. 2. Forehead. 3. Neck. 4. Withers. 5. Back. 6. Ioins, 7. Hip. 8. Pelvic arch. 9. Rump. 10. Pin bone. 11. Shoulder. 12. Chest. 13. Heart Girth. 14. Side. 15. Belly. 16. Flank. 17. Milk well. 18. Milk vein. 19. Fore udder. 20. Udder. 21. Teats. 22. Hind udder. 23. Thigh.

Dairy Temperament. This is indicated by a rather spare, angular form; large, bright, expressive eyes, far apart and placid; a rather long, clean face slightly dished; forehead wide and rather long; wide juncture of head and neck; a large, straight, prominent backbone with well defined spinal processes; ribs and vertebrae wide apart; sharp withers; spare, incurving thighs; and a high arching flank: all of which indicates strong nerve development, or power to do work.

Feeding Capacity. This is indicated by a long, broad, deep, capacious barrel, showing well sprung ribs diverging toward the rear; a broad muzzle; and a strong jaw. 
Constitution. This is indicated by large, bright, clear eyès; large, open nostrils; wide, deep chest; strong navel development; strong abdominal walls; absence of extreme refinement; and a soft, pliable skin with plenty of secretion: all of which indicates strength and vitality.

A heavy milker is one of the hardest worked of all animals, and unless possessed of a strong constitution, she can never do her maximum work and an early breakdown may be expected.

Milk Organs. These include a large, evenly quartered, elastic udder, running well forward and well up behind; large, tortuous milk veins running well forward and branched; numerous, large, capacious milk wells; and medium sized teats, squarely placed, and far apart.

Large, Acshy udders are undesirable, as they possess a relatively small milk elaborating capacity, and are more subject to disorders than moderately large, clastic udders.

The milk veins, which carry the blood away from the udder, are deserving of careful attention. When the orifices (milk wells) through which they enter the body are large, the size of the milk veins may be taken as a fair indication of the amount of blood they carry.

A large flow of blood away from the udder presupposes a large flow into it, and since milk is secreted from the blood, the quantity which flows through the veins must be some indication of milk producing capacity.

Quality. This is indicated by a soft, oily, pliable skin, of medium thickness; short, soft silky hair; yellow secretion in the ears; fine textured bone; rather small and refined ears and horns; yellowish wax at the base of the horns; and a general absence of coarseness in any part.

Pelvic Region. This should be large to afford room for the calf, especially during its delivery. A good pelvic 
region is indicated by a high, long, broad rump, broad hips and loins, and good width between the pin bones.

Additional observations on type should be directed to the following: Shoulder, free from flesh and rather sharp at the withers; tail, long and refined; hocks, clean, well apart, and pointing straight backward, giving roominess for the udder; front legs, straight and well apart, with toes pointing directly forward.

The cscutchcon, which refers to the rear portion of the animal where the hair turns up, was the subject of considerable study by a Firenchman named Quenon, who regarded the size and shape of it as the chief indication of merit in dairy cows. At the present time, however, very little importance is attached to this point.

\section{PURI'TY OF BREEDING.}

Selection is based upon the law that "like produces like." According to this law the characters of the parents are transmitted to the offspring with a greater or less degree of certainty. The purer the breeding of the parents the greater the certainty of such transmission. Thus, for example, one can figure with much certainty that the progeny of pure-bred parents of the same breed will resemble its parents in all essential characteristics. On the other hand, there is no certainty whatever that the off-spring of parents of promiscuous breeding will resemble its parents, either in important or unimportant particulars. It may be like them or it may be totally unlike them.

It is the long period of breeding along one line without admixture of foreign blood that gives the pure-bred animal the superior power of transmitting its qualities to its offspring, a power which is known as prepotency. In the building up of a dairy herd it is of the highest im- 
portance to have animals which transmit their qualities to their offspring with a high degree of certainty, and it is for this reason that pure-bred animals are so much preferred to those of promiscuous breeding.

\section{PEDIGREE.}

A pedigree is a recorded statement of the ancestry of an animal. It is furnished in many cases simply as a guarantee of purity of breeding. Its real value, however, is determined by the merit of the animals which it represents. A 300 pound butter cow with an unbroken list of noted dairy performers back of her is much to be preferred to a 300 pound cow among whose ancestors some inferior individuals are found, and especially if the inferior individuals are near ancestors.

While, generally, pedigreed animals are much to be preferred to those of promiscuous breeding, it by no means follows that all pedigreed animals are desirable. Far from it. There probably are now-a-days as many poor pedigreed dairy animals as good ones. "Scrubs" are found among pedigreed cows just as they are found among common or native cows, though of course far less frequently.

The reason of the existence of inferior individuals among pure-bred dairy animals is found in the fact that eligibility to registration in most cases is not based upon : production or individual excellence, but upon: purity of : breeding. 'This fact has: made' it: possible for : many animals to enter the herd register which, by nature, were. fit only for the shambles. In the purchase of pure-bred stock; therefore, no judicious selection can be made from a mere list of names of individuals, no matter how long this list is or how "high sounding" the names it contains 
may be. One must know the production and individual excellence of the animals represented in the pedigree. The greatest stress should be laid upon the near or immediate ancestry of the animal under consideration.

Fortunately there is what is known as an advanced registry, or register of merit, the basis of admission to which, in addition to pure breeding, is the merit of the individuals as dairy performers. It is much to be hoped that this method of registration will soon replace entirely the common method whose sole requisite for registration is purity of breeding.

HEALTH OF ANIMALS.

The prevalence of tuberculosis, contagious abortion, and other diseases, makes it imperative to make the matter of health an important consideration in the selection of dairy animals. Indeed diseased animals, no matter how valuable in other respects, should be rigidly excluded from the herd.

It is the height of folly to select dairy animals without making rigid inquiry as to their freedom from tuberculosis and contagious abortion. Yet there are many who do not even inquire about these and other diseases, much less make investigation such, for example, as a tuberculin test. 


\section{CHAPTER IV.}

SELECTION OF DAIRY SIRES.

The importance of the dairy sire is recognized in the expression, "The bull is half the herd." Usually, however, the bull is more than half the herd, either for good or bad. In the case of common or grade cows, for example, the pure-bred bull may count for three-quarters or more of the herd, by reason of his greater prepotency. To so great an extent does the bull determine the improvement or deterioration of the herd as to call for the utmost caution in his selection, which should be based upon the following: ( I) purity of breeding; (2) pedigree; (3) type; (4) prepotency; and (5) health.

Furity of Breeding. Under no circumstances should anything but pure-bred sires be used. The value of purity of breeding has already been discussed under the selection of the dairy cow. It should be understood, however, that purity of breeding is of greater consequence in bulls than in cows, for the reason that improvement in the herd is usually expected to be brought about through the dairy sire.

Pedigree. In the case of a dairy bull, especially a young bull, his chief value is determined by the performance of his ancestry. The points of greatest importance to consider in his pedigree are the following: (I) the merit of his mother and his sire's mother; (2) the merit of the daughters of his sire and grand sire; (3) the value of the daughters of his dam and his grand-dam; 
(4) the value of his sisters, if he has any; and (5) the value of his own progeny, if he has any.

The further back consecutively good records can be traced the more valuable the animal. It should always be remembered, however, that near ancestors count for a great deal more than those more remotely related.

Type. The external qualities of a good sire are indicated by a masculine head and neck; bright, prominent eyes, far apart; a strong, sinewy jaw; broad muzzle; wide open nostrils; deep, broad chest; deep, capacious barrel; soft, loose, oily hide, of medium thickness; clean bone; large rudimentary teats, squarely placed and far apart; and a general spareness of flesh, especially in the region of the shoulders, thighs, and hips. Indeed, from the shoulders backward, the dairy bull should have the same general outline as that possessed by the dairy cow. He should have a strong, resolute appearance and an active style, showing that abundance of vigor so necessary in a good breeder.

Frepotency. It has already been stated that this term signifies the power which an animal possesses of transmitting its own qualities to its offspring. The possession of this power is of the highest importance in a dairy bull, for it matters little how good a pedigree or how fine an individuality he may have, if he lacks in the power of transmission he is a failure. Prepotency in an animal increases with the purity and closeness of breeding, and is indicated to some extent by a strong, resolute, vigorous appearance, reflecting a strong constitution and an abundance of nerve development.

The full extent, however, to which a sire is prepotent can be determined with certainty only from his offspring. 
It is for this reason that a middle-aged bull is so much more desirable than a young, untried bull.

A bull with descendants is always the safest animal for the purchaser to buy. Nothing can speak more for a bull than the satisfactory performance of his offspring.

Health. Everything that has been said with reference to health in the selection of cows (p. I6) applies with equal force to dairy sires. 


\section{CHAPTER V.}

BUILDING UP A DAIRY HERD.
I. PRINCIPLES INVOLVED.
II. STARTING THE, HERD.
III. BREEDING UP THE HERD.

\section{PRINCIPLES INVOLVED.}

Underlying Law. The success in building up a dairy herd depends to a great extent upon one's ability to select individuals with reference to the points considered in the preceding two chapters; that is, the ability to make a judicious selection of both males and females. To emphasize more fully the importance of rigid selection it should be remembered that all selection is based upon the law that "like produces like," or that the offspring will be like the parents. The essence of this law is that good milkers will produce good milkers and poor milkers will produce poor milkers.

The uniformity with which this law operates is dependent upon three things: (I) purity of breeding; (2) closeness of blood relationship; and (3) similarity of parents.

Purity of Breeding. The purer the breeding the greater the certainty with which animals will transmit their own characteristics to their offspring. See p. I4.

Closeness of Blood Relationship. The characters of parents of the same strain will reappear in the progeny with greater regularity than those of parents of different strains in. the same breed. This fact is recognized in in-and-in breeding, which is an attempt to secure and 
speedily fix desirable characters by close breeding. Inand-in breeding can be practiced with success, however, only in the hands of skilled breeders.

In the case of crossing one breed upon another as, for example, a Holstein-Friesian upon a Jersey, it is often mistakenly supposed that the progeny of such a cross partakes equally of the characters of both parents. This may occur in some instances, but more often the offspring will resemble either one parent or the other, or neither. But even where the offspring does partake equally of the characters of both parents, such a cross is undesirable because the offspring is not capable of transmitting its characteristics with any degree of certainty. In the hands of the average dairyman transmission in crossing is uncertain and unsatisfactory, and for this reason crossing should not be attempted.

When a cow of nondescript or promiscuous breeding is bred to a pure-bred sire, the progeny will largely partake of the characters of the sire, by reason of his greater prepotency. With what degree of regularity and to what extent this occurs depends upon the degree of prepotency. The offspring of a highly prepotent sire and a common or native cow will take on nearly all the essential characteristics of the sire. In such a case it is plainly seen that the sire counts for a great deal more than half the herd.

In the case of grade cows the influence of the purebred bull becomes less the closer the grade approaches purity of blood. But only in the case where the cows are pure-bred, or more strictly of equal prepotency with the bull, can it be said that the bull is only half the herd.

Similarity of Parents. In mating animals it should always be remembered that the greater the similarity of all their characteristics the greater the certainty of trans- 
mission. Where animals of great extremes of size, conformation, function, disposition, or nervous organization, are mated, somewhat the same results may be looked for that are obtained in crossing animals of different breeds.

Mating animals of highly dissimilar characteristics is spoken of as violent mating and should be avoided. Where there is much similarity in the parents there is usually a satisfactory transmission of qualities and the mating is often referred to as good "nicking."

\section{STARTING THE HERD.}

Grade Cows and Pure=bred Sires. With the average farmer, the cheapest and most satisfactory way of starting a dairy herd is to select as foundation stock good grade cows and a pure-bred bull of one of the strictly dairy breeds. The grading up will be most rapid when the predominant blood in the grades corresponds with the blood of the sire.

A foundation of this kind, of course, does not produce stock that can be registered, but by continuing the use of good, pure-bred bulls of the same blood, stock is soon obtained which, so far as milk and butter production is concerned, very closely approaches in value that of pure breeding.

Pure=Bred Cows and Sires. To start with a purebred herd is practically beyond the means of the majority of farmers. Furthermore, there is an objection to placing well-cared-for, pure-bred cows under average conditions as to feed, care, and management, because under any such change the attainment of satisfactory results would be practically impossible. Where there is a gradual infusion of pure blood, as in the case of grading up a herd with pure-bred sires the 
new blood is gradually accustomed to the change of environment and the herdsman is given the necessary time to change his methods to meet the requirements of pure-bred cattle.

Where the dairyman understands the management of pure-bred stock and has the means with which to purchase the right hind, a pure-bred herd may be started to good advantage.

One of the chief dangers in starting with a purebred herd is the lack of funds to procure the right sort of animals. Instead of purchasing a pure-bred bull and a number of pure-bred cows of common merit, it is better policy to buy relatively cheap. grade cows, and to add the money thus saved to that originally set aside for the bull. This extra money is likely to be the means of securing a bull of outstanding merit.

\section{BREEDING UP THE HERD.}

Importance of Sire. Whether the cows be grades or pure-breds, it is of the highest importance in building up a dairy herd to secure a pure-bred bull of outstanding dairy merit. Unless the bull is descended from good milkers it is folly to expect him to produce good milkers, no matter. how fine or ideal he may be as an individual.

It is, furthermore, of importance to remember that a herd cannot be successfully built up unless the bulls that are successively used belong to the same breed. If the grading up is begun with a Jersey bull the process must be continued uninterruptedly by the use of Jersey blood.

In the selection of a herd bull the points discussed in the preceding chapter should be carefully considered.

Selecting the Best Calves. IVith a first-class bull at the head of the herd, rapid improvement is effected by 
selecting and retaining calves from only the best milkers, at the same time culling out those cows whose records have not been satisfactory. This work cannot be done to best advantage unless records are kept of the quantity and quality of milk from each cow for a whole lactation period, as discussed in chapter IX.

Buying Cows. Where all of the cows in the foundation stock are grades, none of the calves, of course, can be registered. It is desirable, therefore, to add to the herd from time to time, as means permit, some good pure-bred cows of the same blood as the bulls that have been used. This has the advantage of enabling the owner to dispose of his calves to better advantage.

The purchase of cows, however, is always attended with the danger of introducing contagious diseases into the herd, especially tuberculosis and contagious abortion. For this reason the purchasing of cows should be carried on in a limited way only. It is, of course, always in order to buy cows when the object is to add to the herd purebred individuals of exceptional dairy merit. But the practice of buying cows should never be carried to the point of making it the principal means of replenishing the herd, especially since the latter can be accomplished much more satisfactorily by raising the calves from the best cows. 


\section{CHAPTER VI. \\ BREEDS OF DAIRY CATTLE. \\ JERSEY CATTLE.}

The native home of this breed is the Island of Jersey, situated off the coast of France, and comprising 28,7I7

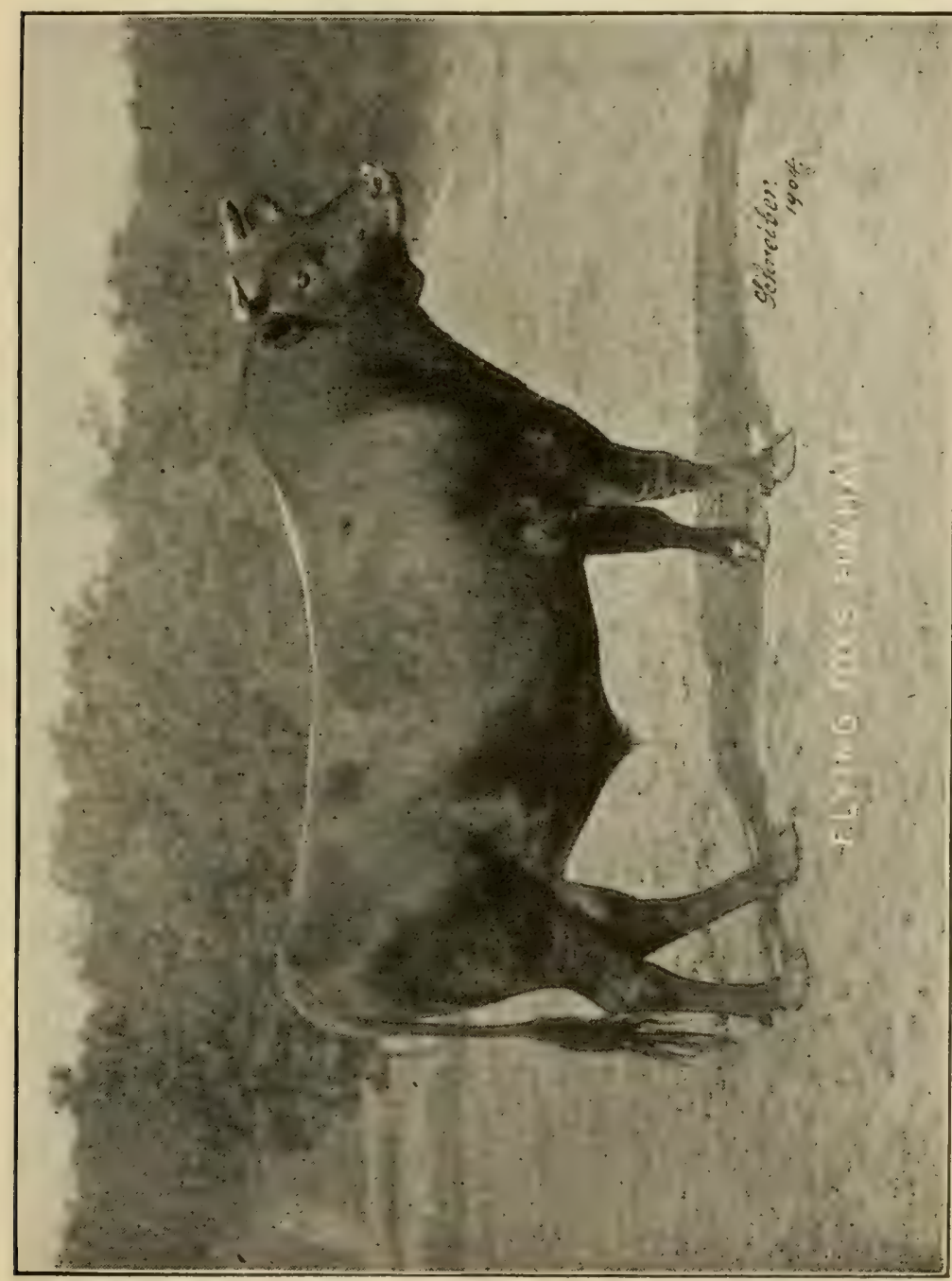

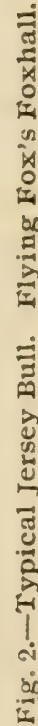


acres. Tle climate is very mild and healthful, and the soil is very productive. Here the Jersey cattle have been bred pure for a number of centuries.

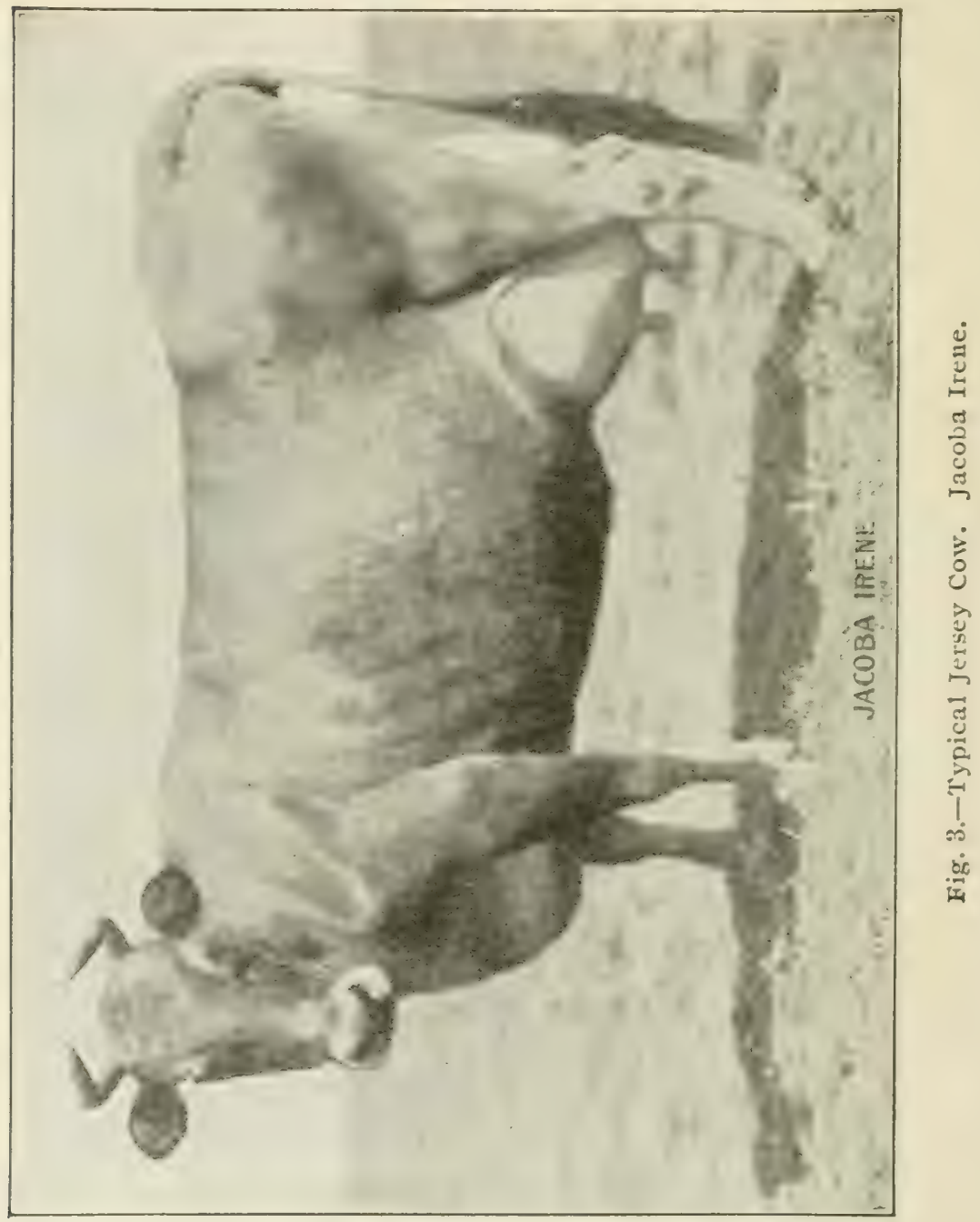

Characteristics. The color of Jerseys is usually some shade of fawn. Cream, dun and yellow are common, and these are frequently mixed with white. In form Jerseys 
are spare, possessing a rather large barrel, a refined head and neck, and fine, clean-cut limbs. In size they are small to medium, the average weight of cows being probably somewhat less than 900 pounds. The quantity of milk produced by Jerseys is, as a rule, not very large, but the milk is very rich, making them excellent butter producers. The color of the milk and butter is a pleasing, rich yellow.

\section{GUERNSEY CATTLE.}

The native home of this breed is the Island of Guernsey, situated near the Island of Jersey, and, like it, is one

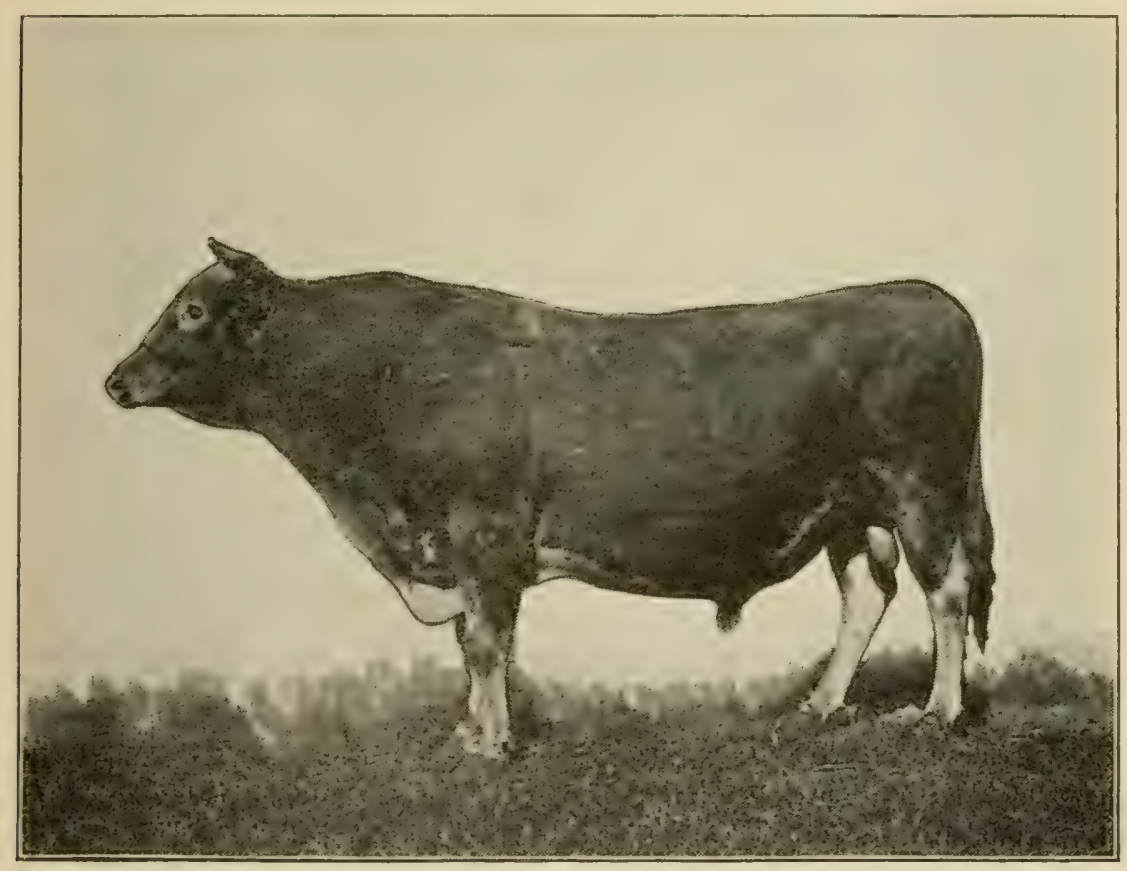

Fig. 4.-Typical Guernsey Bull. Benjamin.

of the group of islands known as the Channel Islands. In size the Island of Guernsey ranks next to that of Jersey. Its climate is very mild and healthful and the soil is pro- 
ductive. Guernsey cattle have been bred pure for a long period of time.

Characteristics. Guernsey cattle are larger, stronger in frame and constitution, and in general more rugged than Jerseys. A noted characteristic of this breed is the very rich, yellow color of the milk and skin. Their predominant color is a reddish fawn, with more or less white

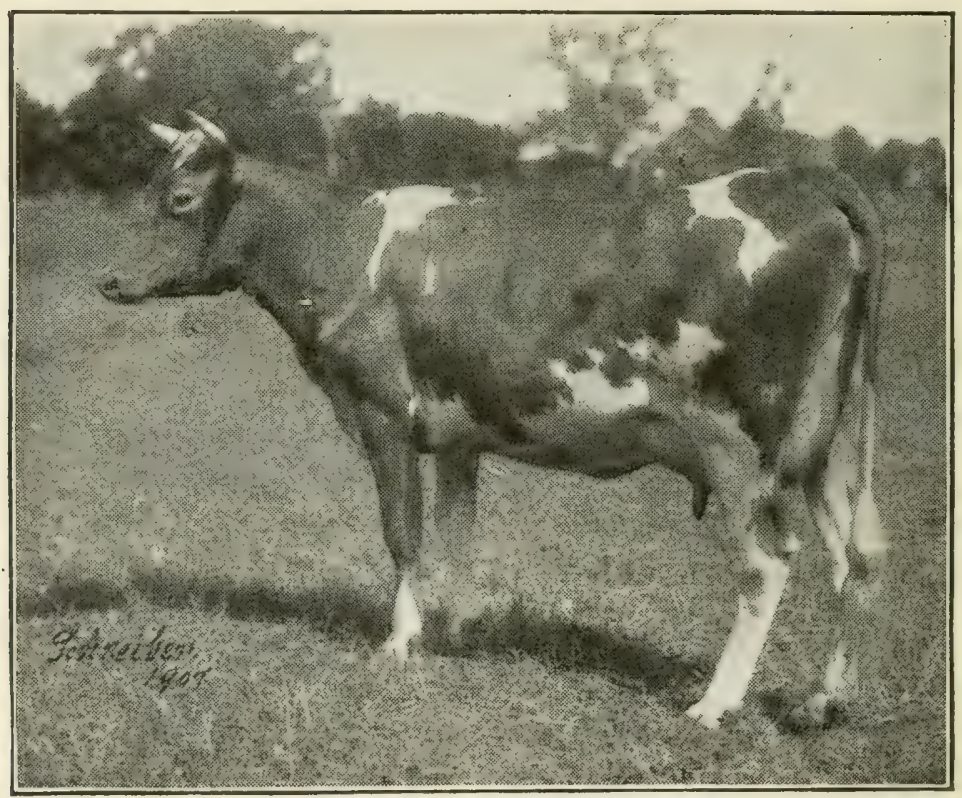

Fig. 5.-Typical Guernsey Cow. Dolly Dimple.

markings. Colors bordering on a yellowish or brownish fawn with white markings, are also common. The cows average probably somewhat more than I, OoO pounds in weight. They average a fairly large yield of milk, which is practically as rich as that produced by Jerseys. Guernseys are also noted for their quiet, gentle disposition. 
HOLSTEIN-FRIESIAN CATTLE.

The native home of this breed is Holland, where it has existed for many centuries. The low, level, rich lands reclaimed from the sea, furnish an abundance of grazing

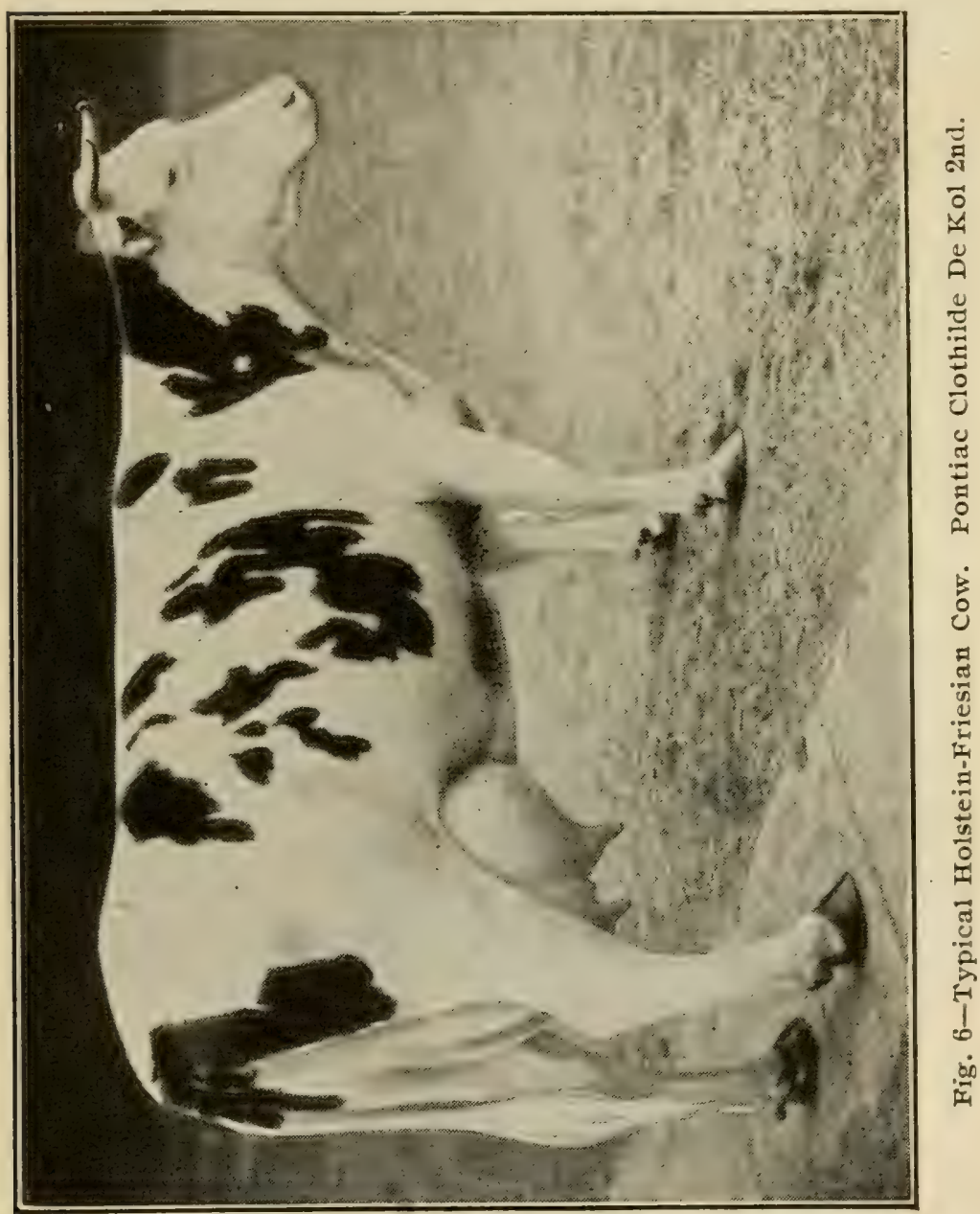


and have given rise to a large breed of cattle. The winters of Holland are rather cold but not severe.

Characteristics. The Holstein-Friesian cattle are white and black in color, have large, strong frames, and

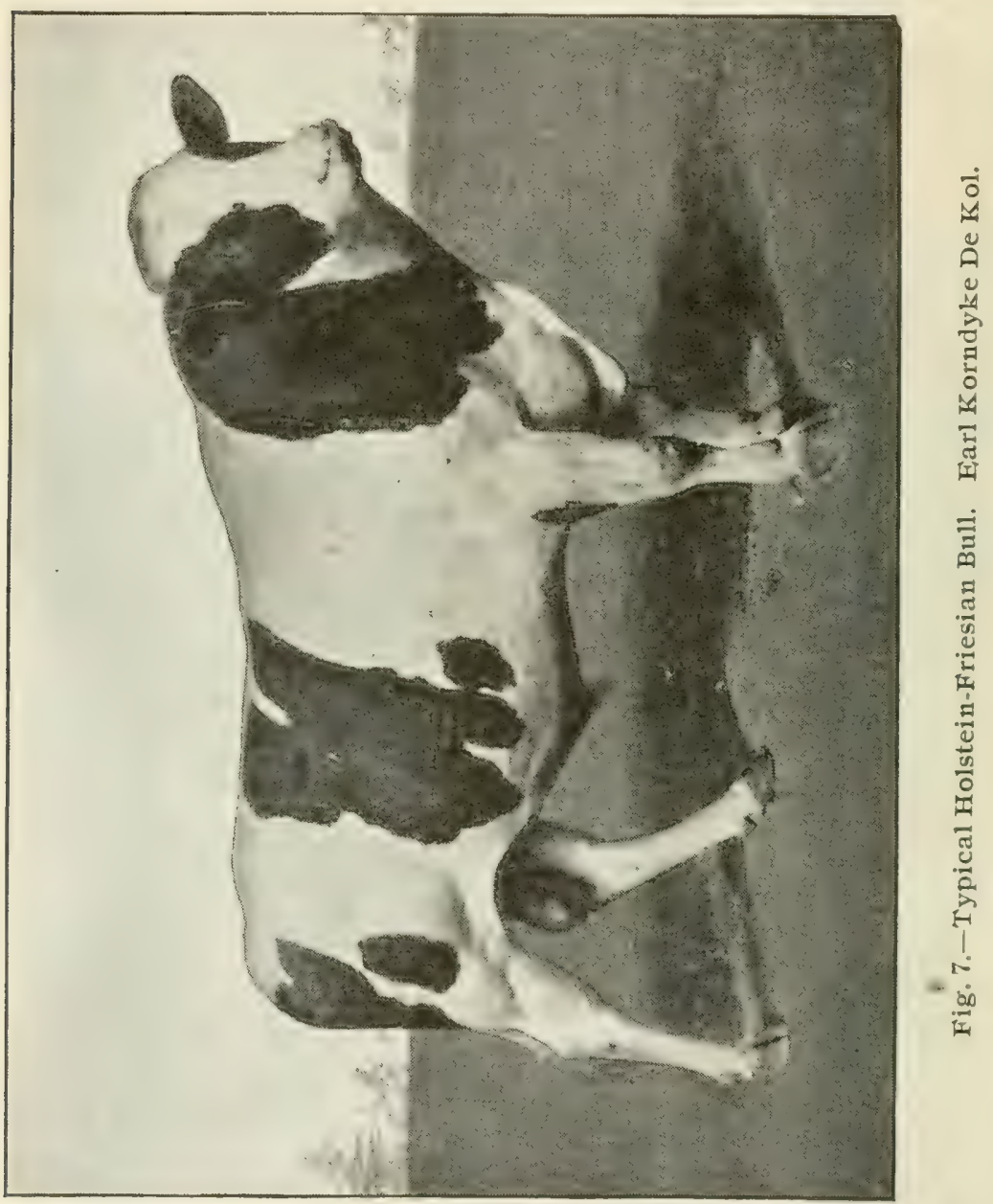

easily stand at the head in size and quantity of milk yielded. The average weight of the cows approximates 1,300 pounds. While noted for their phenomenal milk yields, the milk averages rather low in per cent of 
butterfat, being lower than that of any other clairy breed. The udlers and milk veins in this breed are conspicuously large. The shoulders are rather prominent and the hind quarters as a rule, are rather thick and straight.

\section{AYRSHIRE, CATTLE,}

The native home of this breed is Ayr county, Scotland, from which place the breed derives its name. The

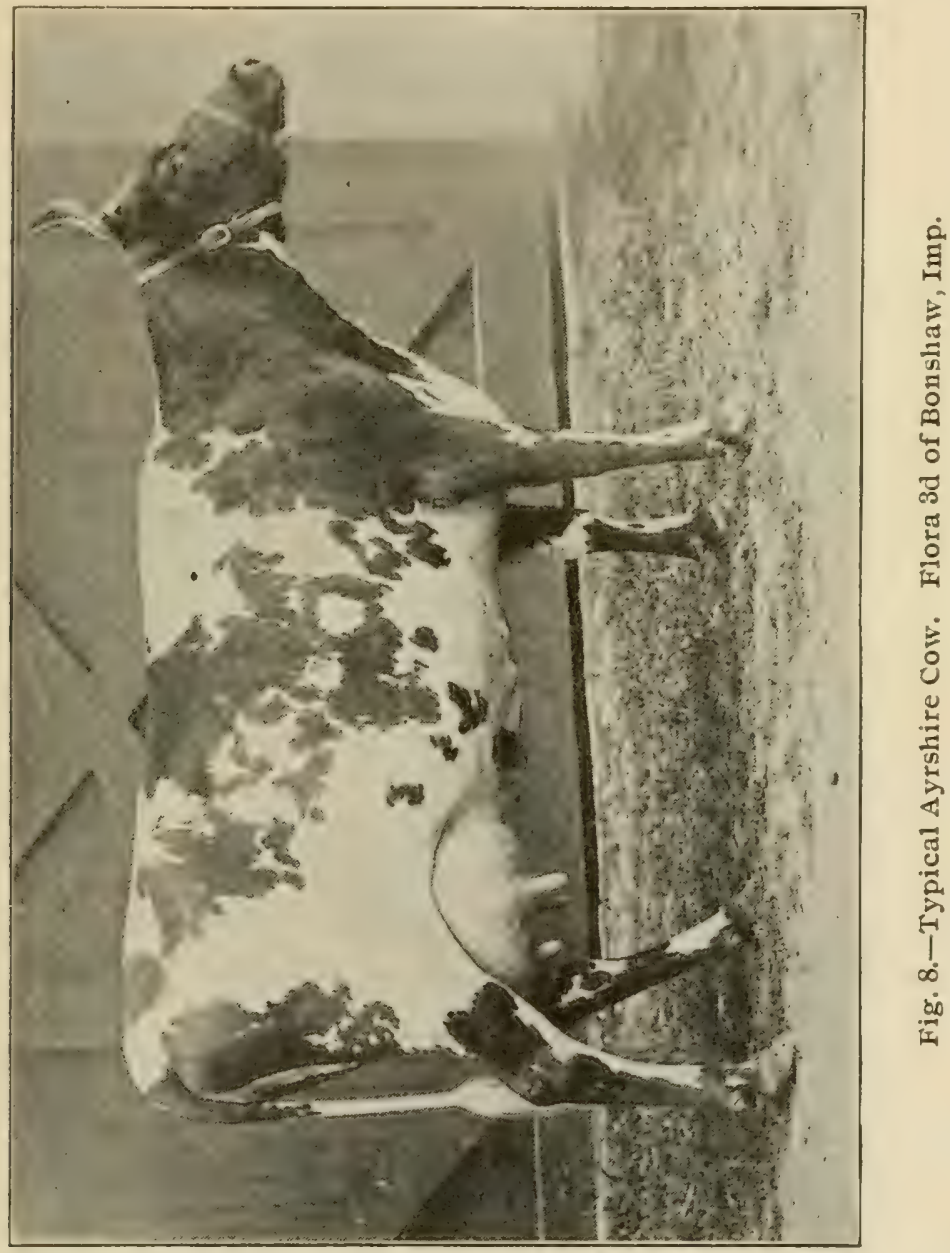

pastures are good, but the climate is rather severe and rough, giving this breed a high degree of hardiness. 
Characteristics. The Ayrshire cattle are a rather hardy, rugged breed, of medium size, the average weight being about I,Ooo pounds. They have a deep capacious barrel, and the hind quarters are inclined to be fleshy. In color they may be red, white, or brown, or a mixture of these, each color being well defined. The cows give a good yield of milk containing an average per cent of butterfat. Their udders possess a high state of perfection.

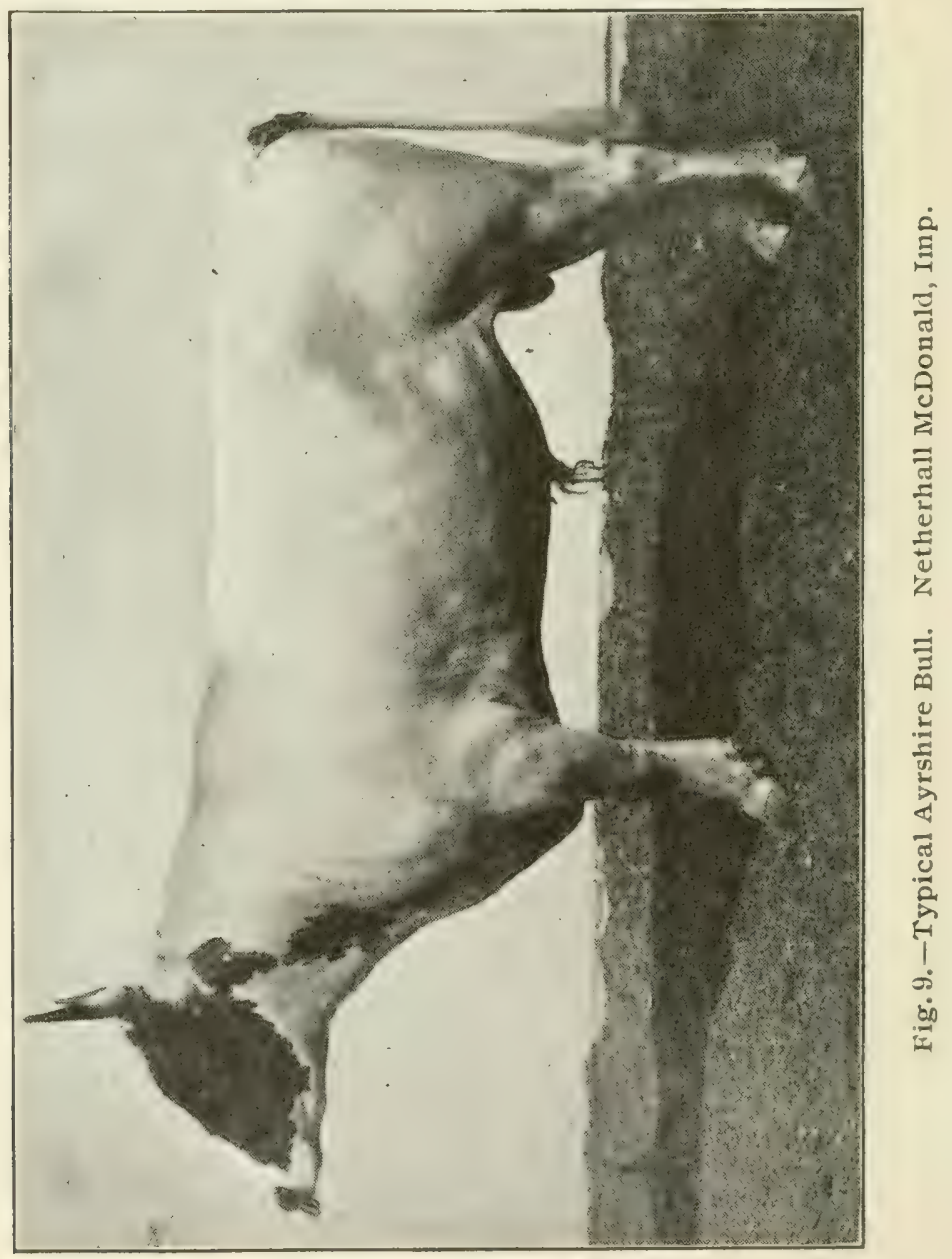




\title{
CHAPTER VII.
}

\section{FEEDING THE DAIRY COW.}

\author{
I. PRINCIPLES OF T'EEDING. \\ II. PRACTICE OF FEEDING. \\ III. FEEDING TABLES.
}

\section{PRINCIPLES OF FEEDING.}

No phase of the dairy industry has received so much attention in recent years as that relating to the principles and practice of feeding. We have come to learn that certain underlying principles must be observed if anything like a full measure of success is to be achieved. The first lesson of the student in stock feeding concerns itself with the following particulars regarding feeds: (I) composition; (2) digestibility; (3) succulence and palatability; (4) proportion of nitrogenous and non-nitrogenous nutrients; (5) proportion of roughage* and concentratest; and (6) fertilizing constituents:

Composition. A knowledge of the composition of feeds is necessary for two reasons: First, to enable the feeder to determine t'le relative value of the feeds at his disposal; and secondly, to assist in determining what quantity of feed is necessary to supply the required amount of nutrients.

In studying the composition of feeds we must first of all familiarize ourselves with three important groups of

*Roughage includes the coarser and less nutritious feeds, such as hay, straw, corn fodder, corn silage, etc.

tConcentrates include the more nutritious feeds, such as corn, wheat bran, cotton seed meal, etc. 
nutrients found in all feed stuffs; namely, protein, carbohydrates and ether extract.

Protein is the nitrogenous part of feeds and is by far the most valuable of the different groups of nutrients. Its characteristic element is nitrogen. The white of egg is almost pure protein. Cottonseed meal and linseed meal are very rich in protein, and so are leguminous hays, such as clover, alfalfa and cowpea hay.

Carbohydrates contain no nitrogen but are made up of carbon, hydrogen, and oxygen, containing the latter two elements in the proportion to form water. Sugar and starch are almost pure carbohydrates. Crude fiber is another carbohydrate, which constitutes the woody, fibrous part of plants.

Ether extract is the part of feeds extracted by means of ether, and consists largely of fats or oils. This group of nutrients bears a close similarity to carbohydrates, both in composition and in function; but owing to its higher carbon content, its fuel value is 2.25 times that of carbohydrates. Cotton seed and flax seed are very rich in ether extract.

Dry matter, as the term signifies, is the feed minus its water.

The variation in nutrients in different feeds is illustrated in the following table:

TABLE I. Showing variation in nutrients in different feeds.

\begin{tabular}{|c|c|c|c|c|}
\hline \multirow[b]{2}{*}{ Feed. } & \multirow[b]{2}{*}{$\begin{array}{c}\text { Dry } \\
\text { matter in } \\
100 \text { pounds. }\end{array}$} & \multicolumn{3}{|c|}{ Total nutrients in 100 pounds. } \\
\hline & & $\begin{array}{c}\text { Protein. } \\
\text { Lhs. }\end{array}$ & $\begin{array}{l}\text { Carbo- } \\
\text { hydrates. } \\
\text { Lbs. }\end{array}$ & $\begin{array}{l}\text { Ether } \\
\text { extract. } \\
\text { Lbs. }\end{array}$ \\
\hline Wheat bran............. & 88.1 & 15.4 & 62.9 & 4.0 \\
\hline Cottonseed meal ......... & 91.8 & 42.3 & 29.2 & 13.1 \\
\hline Corn ........... & 89.4 & 10.3 & 72.6 & 5.0 \\
\hline Corn silage...... & 20.9 & 1.7 & 17.0 & 0.8 \\
\hline Corn stover........ & 59.5 & 3.8 & 52.2 & 1.1 \\
\hline Clover hay (red). & 84.7 & 123 & 62.9 & 3.3 \\
\hline
\end{tabular}


The table shows that feeds differ very widely in the amount of nutrients they contain, especially in protein, the most valuable portion of feeds.

Digestibility. While the total nutrients give some idea as to the relative value of different feeds, it is of far greater importance to know the total digestible nutrients as determined by actual digestion experiments with animals. That feeds differ widely in degree of digestibility is shown in the following table which contains the same list of feecis given in Table $\mathrm{I}$.

TABLE II. Showing variation in the digestibility of different feeds.

\begin{tabular}{|c|c|c|c|c|}
\hline \multirow[b]{2}{*}{ Feed, } & \multirow{2}{*}{$\begin{array}{c}\text { Dry } \\
\text { matter in } \\
100 \text { pounds. }\end{array}$} & \multicolumn{3}{|c|}{$\begin{array}{l}\text { Total dige } \begin{array}{c}\text { tible nutrients in } \\
100 \text { pounds. }\end{array}\end{array}$} \\
\hline & & $\begin{array}{c}\text { Protein. } \\
\text { Lbs. }\end{array}$ & $\begin{array}{c}\text { Carbo- } \\
\text { hydrates. } \\
\text { Lbs. }\end{array}$ & $\begin{array}{c}\text { Ether } \\
\text { extract. } \\
\text { Lbs. }\end{array}$ \\
\hline 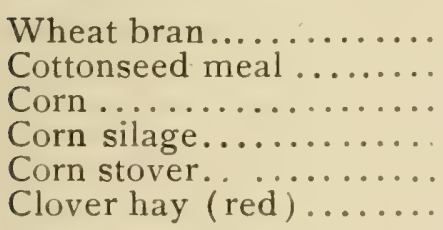 & $\begin{array}{l}88.1 \\
91.8 \\
89.1 \\
20.9 \\
59.5 \\
84.7\end{array}$ & $\begin{array}{r}12.2 \\
37.2 \\
7.9 \\
0.9 \\
1.7 \\
6.8\end{array}$ & $\begin{array}{l}39.2 \\
16.9 \\
66.7 \\
11.3 \\
32.4 \\
35.8\end{array}$ & $\begin{array}{r}2.7 \\
12.2 \\
4.3 \\
0.7 \\
0.7 \\
1.7\end{array}$ \\
\hline
\end{tabular}

Comparing this table with Table I, we note that the digestibility of the protein, for example, in corn stover, clover hay and cottonseed meal is $44 \%, 55 \%$ and $88 \%$ respectively. These figures suffice to show the need of knowing, not so much the total nutrients, as the total digestible nutrients in feed stuffs.

Succulence and Palatability. The amount of digestible nutrients does not always measure the feeding value 
of feed stuffs. Palatability must also be considered. Noreover, experience has amply demonstrated that for best results in milk production, a certain amount of succulent feed must be fed as a part of the ration. Corn silage, which is so highly prized by dairymen, probably owes its high rank as a clairy feed nearly as much to its succulence and palatability as to the nutrients which it contains.

\section{Proportion of Nitrogenous to Non=Nitrogenous} Nutrients. In the production of milk, only the protein or nitrogenous part of the feed can be utilized for the production of the protein or nitrogenous part of the milk. The non-nitrogenous constituents of the milk are largely, if not entirely, produced from the non-nitrogenous constituents of the feed, namely, the carbohydrates and ether extract.

From this it must be obvious that the best results in feeding can be obtained only from a proper balancing of the nutrients fed. Morcover, since the different nutrients are largely to be converted into milk, it is evident also that the quantity which can be advantageously fed must be gauged by the quantity and quality of milk produced. Hence feeders have come to adopt what is known as balanced rations or feeding standards.

Feeding Standards. These refer to the amount of digestible nutrients required per $\mathrm{I}, \mathrm{OOO}$ pounds of live weight in twenty-four hours. They recognize that the nutrients fed must be in proportion to the quantity and quality of milk yielded. This is shown by the WolffLehman standards presented in the following table: 
TABLE III. Showing Wolff-Lehman feeding standards.

\begin{tabular}{|c|c|c|c|c|c|}
\hline \multirow[b]{2}{*}{ Ration. } & \multirow{2}{*}{$\begin{array}{l}\text { Daily milk } \\
\text { y ield. } \\
\text { A verage } \\
\text { quality. } \\
\text { Lbs. }\end{array}$} & \multirow{2}{*}{$\begin{array}{c}\text { Dry } \\
\text { matier. } \\
\text { Lbs. }\end{array}$} & \multicolumn{3}{|c|}{$\begin{array}{l}\text { Digestible nutrients per } 1,000 \\
\text { pounds live weight. }\end{array}$} \\
\hline & & & $\begin{array}{c}\text { Protein. } \\
\text { Lbs. }\end{array}$ & $\begin{array}{c}\text { Carbo- } \\
\text { hydrates. } \\
\text { Lbs. }\end{array}$ & $\begin{array}{c}\text { Ether } \\
\text { extract. } \\
\text { Lbs. }\end{array}$ \\
\hline $\begin{array}{l}\text { No. } 1 \ldots \ldots \ldots \\
\text { No. } 2 \ldots \ldots \ldots \\
\text { No. } 3 \ldots \ldots \ldots \\
\text { No. } 4 \ldots \ldots \\
\end{array}$ & $\begin{array}{l}11.0 \\
16.6 \\
22.0 \\
27.5\end{array}$ & $\begin{array}{l}25 \\
27 \\
29 \\
32\end{array}$ & $\begin{array}{l}1.6 \\
2.0 \\
2.5 \\
3.3\end{array}$ & $\begin{array}{l}10.0 \\
11.0 \\
13.0 \\
13.0\end{array}$ & $\begin{array}{l}0.3 \\
0.4 \\
0.5 \\
0.8\end{array}$ \\
\hline
\end{tabular}

The standard that has generally been used as a guide by feeders is that for ration No. 3. Researches during recent years have shown, however, that the Wolff-Lehman standard calls for too much protein. These researches make it quite clear that the amount of protein required for 22 pounds of average quality milk is nearer two pounds than two and a half pounds, and until the matter is definitely settled, it may be well to adopt two and one-fourth pounds of protein as the standard for the milk yield referred to.

Feeding Standards as Guides. Standards for balanced rations should always be used with considerable flexibility. They should be looked upon only as guides and as such are exceedingly useful. Every practical feeder knows that the influence of individuality counts for much in the feeding of dairy cattle. A ration that may be satisfactory for one cow may not be suited to another.

We have also to consider the source of the nutrients. It is known that the digestible nutrients in coarse feeds yield smaller returns, pound for pound, than those in 
grains. Then again the matter of proportioning the quantity of nutrients to the weight of the animal can at best give only approximate results. The actual milk and butterfat production must always remain the principal factor in determining the (puantity of nutrients required by the dairy cow.

Calculating Rations. By a ration is meant the amount of feed required by an animal in twenty-four hours. The method of compounding rations consists in selecting from the feeds at our disposal such quantities as will contain the amount of nutrients called for by the standard. To illustrate, let us make up a ration for a cow yielding daily 22 pounds of milk of average quality, using the Wolff-Lehman standard (p. 37). The feeds at our disposal are wheat bran, cottonseed meal, corn meal, corn silage, corn stover and clover hay.

By a number of trial calculations we find that the required nutrients are obtained by selecting 9 lbs. of wheat bran, 4 lbs. of corn, I lb. of cottonseed meal, 5 lbs. of corn stover, $5 \mathrm{lbs}$. of clover hay and $30 \mathrm{lbs}$. of corn silage. The calculation is made from Table II (-p. 35) in the manner shown below:

Amt. in 100 lbs.

Protein in 9 lbs. bran

Protein in $1 \mathrm{lb}$. cotton seed meal Protein in $4 \mathrm{lbs}$. corn

Protein in $30 \mathrm{lbs}$. corn silage Protein in $5 \mathrm{lbs}$. corn stover Protein in 5 lbs. clover hay
$=12.2 \times .09=1.098 \mathrm{lbs}$.

$=37.2 \times .01=0.372 \mathrm{lbs}$.

$=7.9 \times .04=0.316 \mathrm{lbs}$.

$=0.9 \times .30=0.270 \mathrm{lbs}$.

$=1.7 \times .05=0.085 \mathrm{lbs}$.

$=6.8 \times .05=0.3401 \mathrm{bs}$.

Total protein $=2.481 \mathrm{lbs}$. Standard $=2.50 \quad \mathrm{lb}$ s. 
Amt. in

100 lbs.

Carbohydrates in 9 lbs. bran $\quad=39.2 \times .09=3.5251 \mathrm{bs}$.

Carbohydrates in 1 lb. c. s. meal $=16.9 \times .01=0.169 \mathrm{lbs}$.

Carbolyclrates in 4 1bs. corn $\quad=66.7 \times .04=2.668 \mathrm{lbs}$.

Carbohydrates in 30 1bs, corn silage $=11.3 \times .30=3.390$ lbs.

Carbohydrates in 5 lbs. corn stover $=22.4 \mathrm{x} .05=1.620 \mathrm{lbs}$.

Carbohycirates in 5 lbs. clover hay $=35.8 \times .05=1.790 \mathrm{lbs}$.

Total carbohydrates $=13.165 \mathrm{lbs}$.

Standard $=13.00$ lbs.

Amt. in

$100 \mathrm{lbs}$.

Ether extract in 9 lbs. bran

$=2.7 \times .09=0.243 \mathrm{lbs}$.

Ether extract in 1 lb. c. s. meal $=12.2 \times .01=0.122 \mathrm{lbs}$.

Ether extract in $4 \mathrm{lbs}$. corn $=4.3 \times .04=0.172 \mathrm{lbs}$.

Ether extract in $30 \mathrm{lbs}$. corn silage $=0.7 \times .30=0.210 \mathrm{lbs}$.

Ether extract in 5 1bs. corn stover $=0.7 \times .05=0.035 \mathrm{lbs}$.

Ether extract in 5 lbs. clover hay $=1.7 \times .05=0.085 \mathrm{lbs}$.

Total ether extract $=0.867 \mathrm{lbs}$.

Standard $=0.50 \mathrm{lbs}$.

To make the above calculation perfectly plain it should be noted that the table on page 35 says that Ioo lbs. of bran contain I $2.2 \mathrm{lbs}$. of protein. If IOO lbs. contain I 2.2 lbs., 9 lbs. of bran will contain nine hundredths of $\mathrm{I} 2.2$ 1bs. or .09 x 12.2, which equals 1.098 1bs. of protein. The method is the same in the remaining computations.

Nutritive Ratio, In speaking of rations, the terms "wide" ration and "narrow" ration are frequently used. The terms refer to the proportion of nitrogenous to nonnitrogenous matter in the ration. This proportion is spoken of as the nutritive ratio, which is obtained by dividing the digestible carbohydrates plus 2.25 (heat equivalent of carbohydrates) times the digestible ether 
extract, by the digestible protein. In the ration calculated above the nutritive ratio equals $\mathrm{I} 3.17+(2.25 \times .87) \div$ $2.48=6 . \mathrm{I}$; that is the nutritive ratio in this case is $\mathrm{I}: 6 . \mathrm{I}$.

When the amount of nitrogenous matter is small as compared with the non-nitrogenous matter, the ration is said to be "wide." When the reverse is true, the ration is said to be "narrow."

Proportion of Roughage and Concentrates. According to our feeding standard, a cow yielding 22 pounds of - milk requires a ration containing i 6 pounds of digestible nutrients and a total of 29 pounds of dry matter (digestible and indigestible). This amount of dry matter means that the ration must have a fairly definite bulk. Where the ration contains a great deal of rich concentrates in proportion to roughage, it is apt to lack in bulk. On the other hand a ration containing a large proportion of corn stover, oat straw and similar roughage, is likely to make the ration so bulky as to make it impossible for a heavy producer to consume enough of it to obtain the required nutrients.

In the ration calculated on page 38 the proportion of roughage and concentrates is about right. Under average conditions a cow yielding 22 pounds of milk should have a ration composed of about two-thirds roughage and onethird concentrates. For greater yields it is best, as a rule, to increase only the concentrates to meet the requirements of the additional flow of milk, thus making the proportion of concentrates to roughage greater the larger the yield of milk.

Fertilizing Constituents of Feed. These are nitrogen, phosphoric acid, and potash. Feeds rich in these constituents will produce manure correspondingly rich in them. In the selection of feeds, therefore, some atten- 
tion should be given to their manurial value, especially since feeds differ so widely in this respect.

An illustration of the extent to which feeds differ in their fertilizing or manurial constituents is given in the following table, which shows the amount of nitrogen, phosphoric acid and potash contained in corn and cotton seed meal. The table also shows the value of these constituents, which was obtained by rating the nitrogen at I 5 cents per pound, and the phosphoric acid and potash at $4 \frac{\mathrm{T}}{2}$ cents per pound.

TABLE IV. Showing fertilizing constituents in corn and cottonseed meal.

\begin{tabular}{|c|c|c|c|c|}
\hline \multirow[b]{2}{*}{ Feed. } & \multicolumn{4}{|c|}{ Fertilizing constituents in one ton. } \\
\hline & $\begin{array}{c}\text { Nitrogen. } \\
\text { Lbs. }\end{array}$ & $\begin{array}{l}\text { Phos- } \\
\text { phoric } \\
\text { acid. } \\
\text { Lbs. }\end{array}$ & $\begin{array}{c}\text { Potash. } \\
\text { Lbs. }\end{array}$ & $\begin{array}{l}\text { Total } \\
\text { value. }\end{array}$ \\
\hline 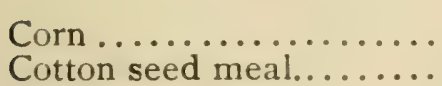 & $\begin{array}{r}36.4 \\
135.8\end{array}$ & $\begin{array}{l}14.0 \\
57.6\end{array}$ & $\begin{array}{r}8.0 \\
17.4\end{array}$ & $\begin{array}{l}\$ 6.45 \\
23.75\end{array}$ \\
\hline
\end{tabular}

The table shows that the fertilizing value of a ton of cottonseed meal exceeds that of a ton of corn by $\$ 17.30$, an amount that certainly must appeal to the man who is dairying on a business basis.

II. PRACTICE OF FEEDING.

Frequency of Feeding. The main part of the ration should be supplied in two feeds; one in the morning and the other in the late afternoon. It is desirable to feed some dry roughage at noon, especially when the roughage in the morning and evening consists of silage. The cow, 
on account of her large store room, the paunch, is capable of storing up a large (puantity of feed and, therefore, does not require as many feeds as some other farm animals.

Order of Feeding Concentrates and Roughage. As a rule it is best to feed the concentrates just previous to milking and the roughage immediately thereafter. The grain helps to attract the cows to their stalls, and, by feeding the roughage after milking, we avoid tainting the milk with undesirable odors when the roughage contains these. When corn silage, for example, is fed immediately before milking, its odor is always perceptible in the milk. When fed after milking, the odor is never detected. It is believed also that feeding the concentrates by themselves will result in a more thorough mixing of saliva with them and thus increase their digestibility. Furthermore, a great deal of dust can be avoided by feeding the roughase after milking. particularly when the roughage consists of hay or dry fodder.

A prevailing opinion that heavy concentrates will form an injurious, pasty mass in the cow's stomach does not seem to be well founded. When the concentrates are fed directly before milking and the roughage directly after, there will be sufficient mixing in the paunch before the contents pass into the stomach proper. The author for several years, has successfully followed the practice of feeding concentrates and roughage separately when the former consisted of as much as five pounds of cottonseed meal per day.

Feeding Before and After Calving. Toward the close of the lactation period, the grain ration should be gradually reduced, either because of the reduced flow of milk, or on account of the desirability of drying up the 
cow so that she may have a month's rest before calving. It should be remembered, however, that even while the cow goes dry she still requires nutritious feed to properly nourish the foetus within her. The requirements as to feed at this time call for plenty of succulent roughage, and some grain which is rich in ash and protein, at the same time laxative in character.

If the cow is feeding on good pasture the grain may be entirely withheld a month previous to calving. Indeed, if pasture is luxurious, it is desirable to restrict the time during which she is allowed to graze lest she overfeed and invite milk fever. When no pasture is available, a ration consisting of corn silage, good hay and about four pounds of grain will answer very satisfactorily. A desirable grain ration is made up of linseed meal, wheat bran and ground oats, using these feeds in the proportion of aboit one pound of linseed meal and one and a half pounds each of bran and oats. This ration not only supplies the proper nutrients for the development of the foetus, but owing to its laxativeness, keeps the cow in the best physical condition.

A few days before and after calving the grain is preferably supplied in the form of a warm mash. Warm water should also be freely supplied at this time. 'Three to six days after calving the grain should be gradually increased until the maximum amount consistent with economical production has been supplied.

If the cow has been properly nurtured previous to calving, she will have stored up a considerable amount of reserve material which she draws on immediately after calving, thus making a heavy grain ration at this time not only not desirable but entirely unnecessary.

Feeding Silage. The cheapest and most satisfactory 
roughage that can be produced upon most farms, is corn silage. Its succulence and palatability make it an ideal feed for mill production. This feed should be available upon the farm the larger portion of the year. In winter it takes the place of summer pasturage; during the late summer and fall it is needed to supplement the shortage of pasturage which usually occurs about this time.

An average cow in full flow of milk will consume 40 pounds of silage daily to good advantage. This amount of silage combined with 8 or io pounds of dry fodder or hay makes a good combination of roughage for a dairy cow.

Feeding Grain. It should be remembered that silage contains a large amount of water, and where this feed constitutes the main part of the roughage of the ration, a considerable amount of grain must be fed to supply the required nutrients of a heavy milk producer. The amount of concentrates to be fed is, of course, largely dependent upon the amount of milk and butterfat produced by the cow.

Water. An abundance of pure water is a prime necessity with a dairy cow. This is to be expected from the fact that milk is largely composed of water. Where cows have no access to flowing water, they should be watered regularly morning and night; and during hot weather a third watering at noon is desirable. The fact that milk is composed so largely of water should emphasize the importance of supplying only pure water. We may reasonably expect the same bad effect on the health of the cow and the flavor of the milk from stale, impure water which is noticeable from the fecling of stale, odoriferous feeds.

Salt. Cows should have daily access to all the salt they 
care to lick. Either common granular salt or rock salt will answer the purpose satisfactorily.

Feeding According to Flow. In the economical production of milk, it is absolutely essential to feed cows according to their productive capacity. Just what this productive capacity is can be determined only by keeping a careful account of the feed consumed and the milk and butterfat yielded by each cow individually. Such a record will soon show to what extent cows will profitably respond to the feed given them.

Importance of Feeding a Full Ration. According to the German feeding standard, a cow weighing I,OoO pounds requires for body maintenance 0.7 pound of digestible protein, 8 pounds of cigestible carbohydrates and O.I pound of digestible ether extract. This shows that about half the nutrients called for in a ration for an average milker are used to sustain the body so that it will neither gain nor lose in weight; the other half being used to form milk. Returns for feed can, therefore, be expected only from about $50 \%$ of the total nutrients required by the cow. This means that a cow on a full ration will yield practically twice as much milk as she would on three-fourths of a ration. Yet there are thousands of dairymen who fail to supply the last quarter of a ration and thus bring ruin upon themselves and their business.

\section{TABLE GIVING COMPOSITION OF FEEDS.}

At the beginning, it was stated that a knowledge of the composition of feeds was necessary for two reasons: First, to enable the feeder to determine the relative value of the feeds at his disposal; and second, to assist in determining what quantity of feed is necessary to supply the 
required nutrients. To afford the feeder as wide a choice as possible, a long table of feeds is herewith presented, showing not only the digestible, organic nutrients, but also the fertilizing constituents. This table is taken from Henry's "Feeds and Feeding," by permission of the author.

TABLE V. Average digestible nutrients and fertilizing constituents in American feeding stuffs.

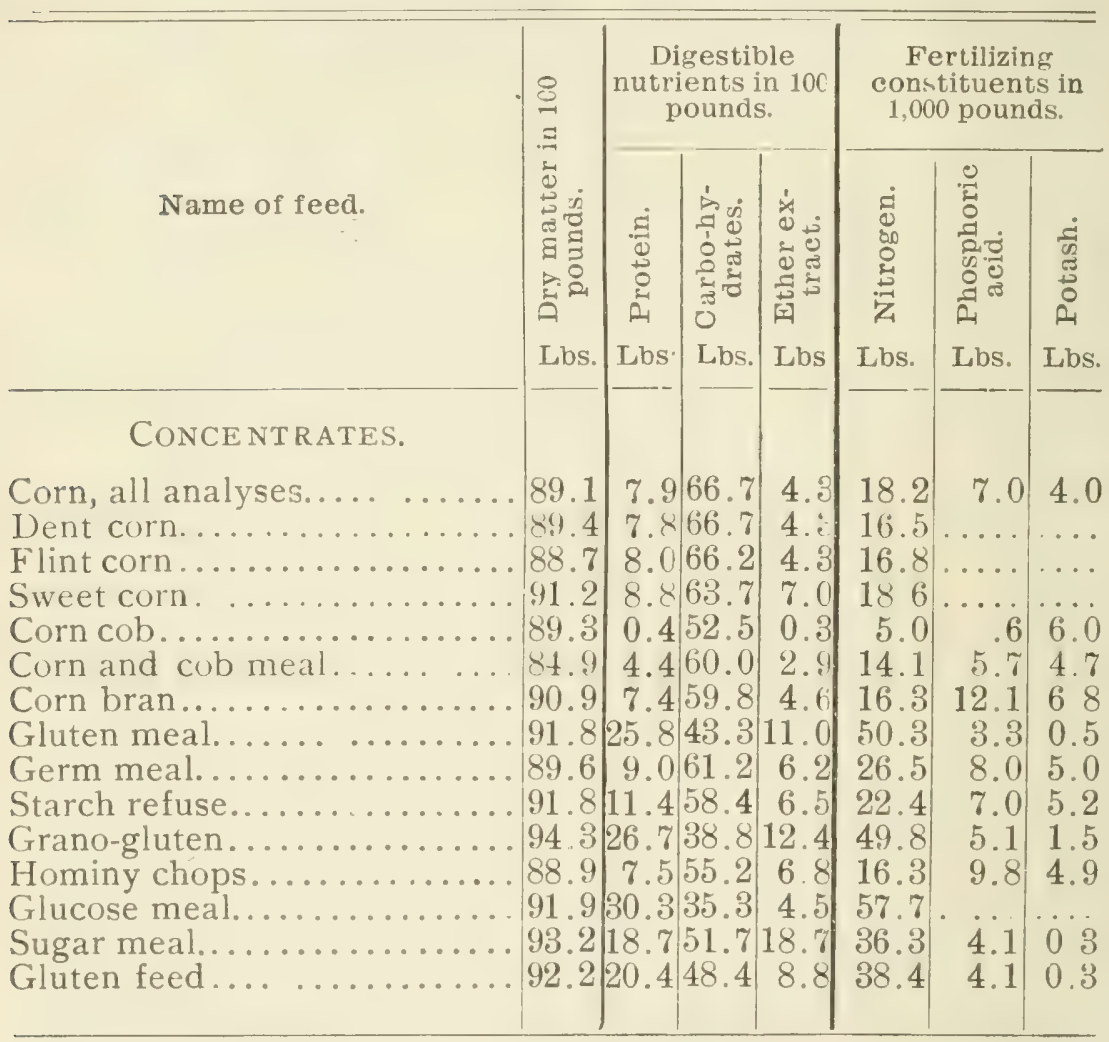


TABLE V. Digestible nutrients and fertilizing constituents.-Con.

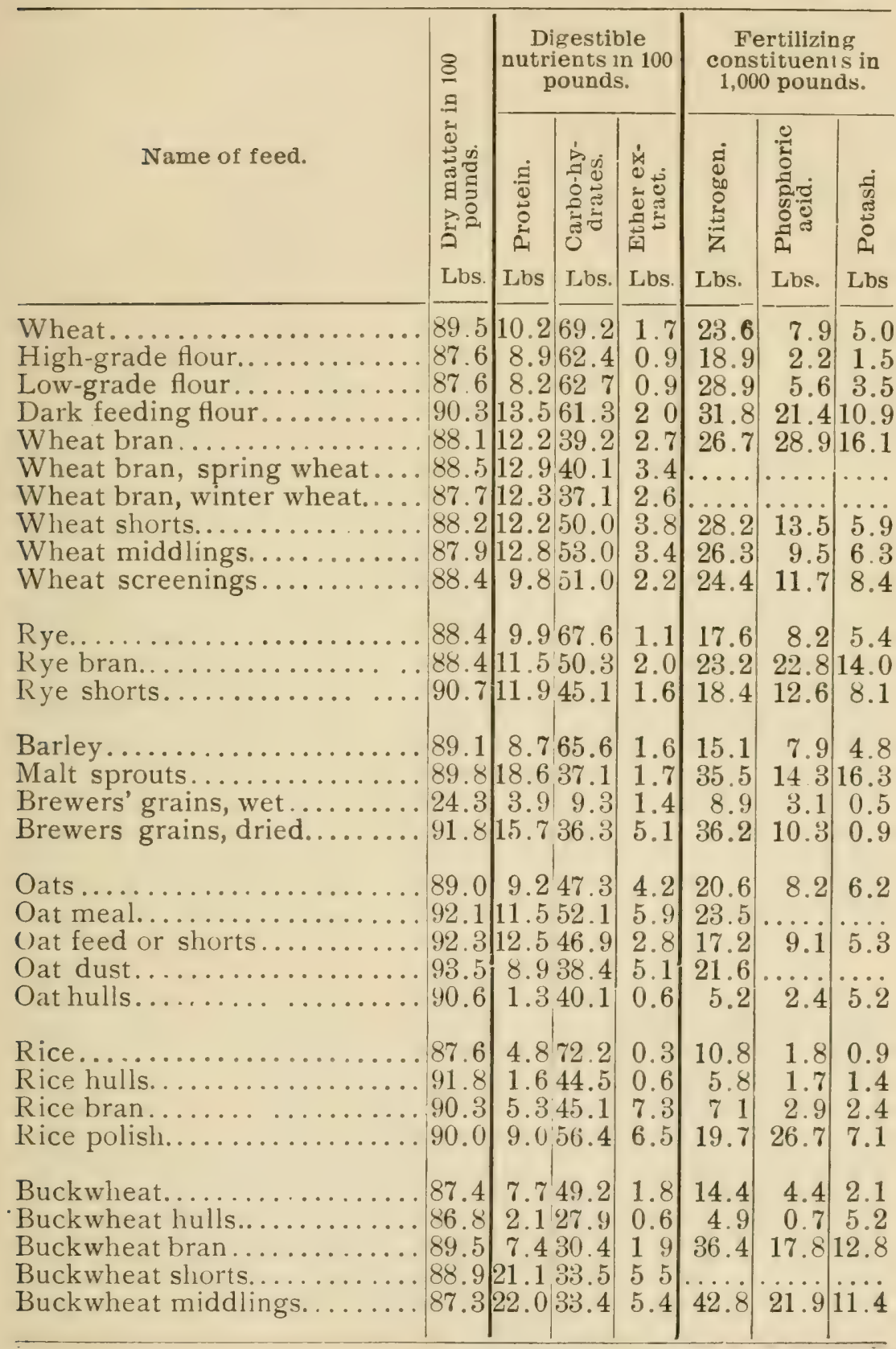


TABLE V. Digestible nutrients and fertilizing constituents.-Con.

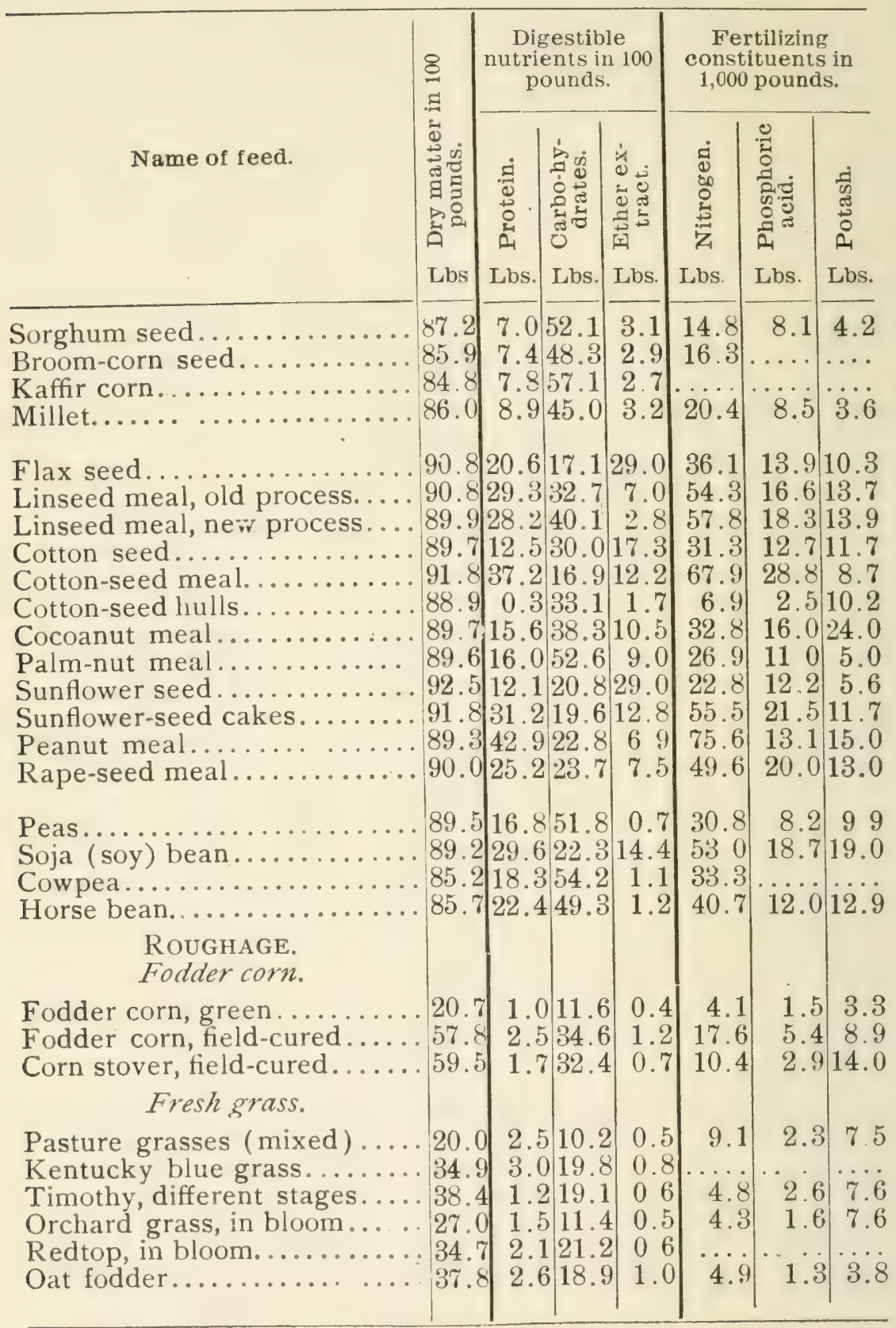


TABLE V. Digestible nutrients and fertilizing constituents.-Con.

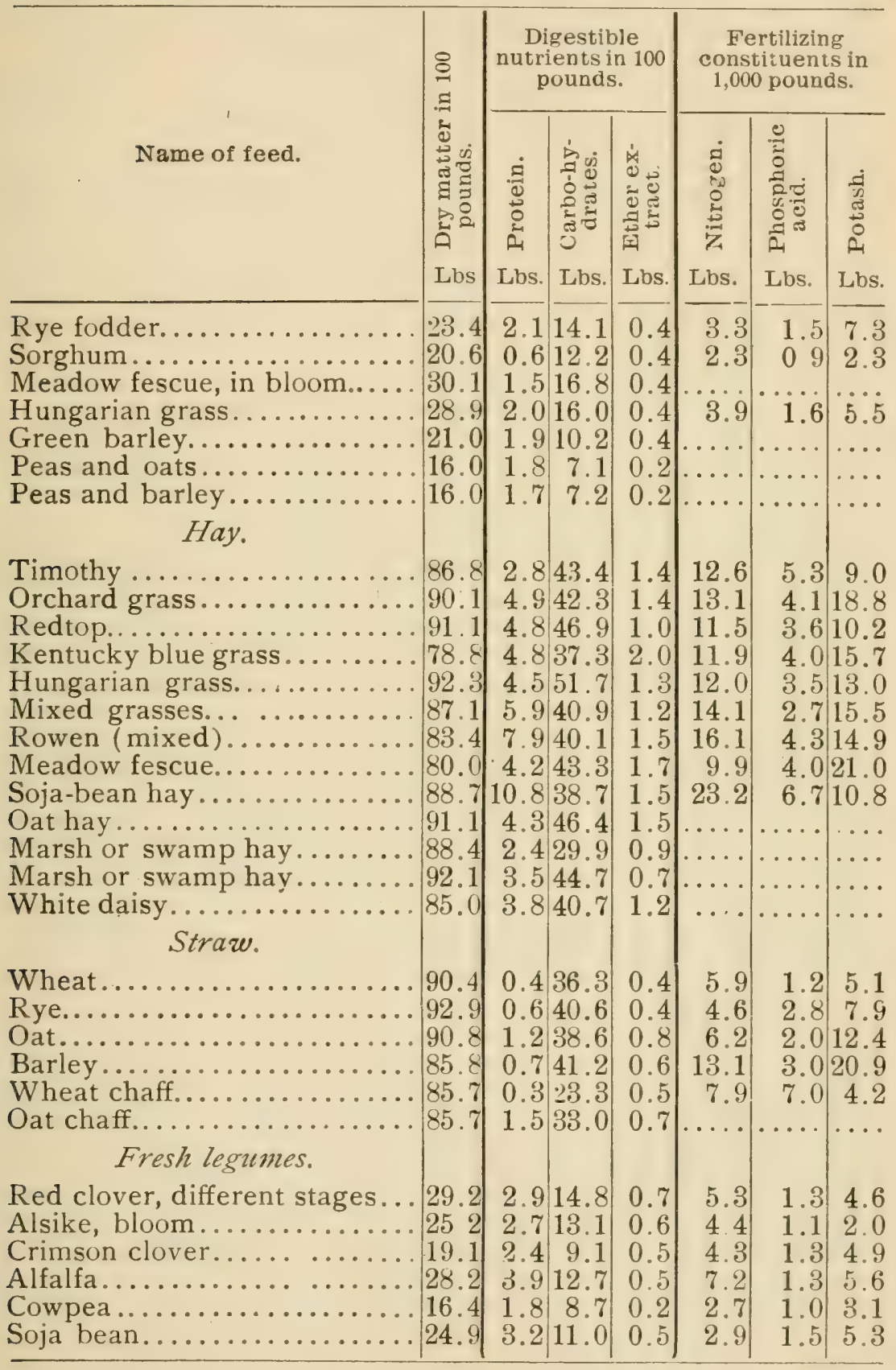


TABLE V. Digestible nutrients and fertilizing constituents.-Con.

Name of feed.

\section{Legume hay and straw.}

Red clover, medium......... Red clover, mammoth....... Alsike clover............... White clover............... Crimson clover.............

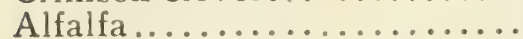
Cowpea.................. Soja-bean straw Pea-vine straw

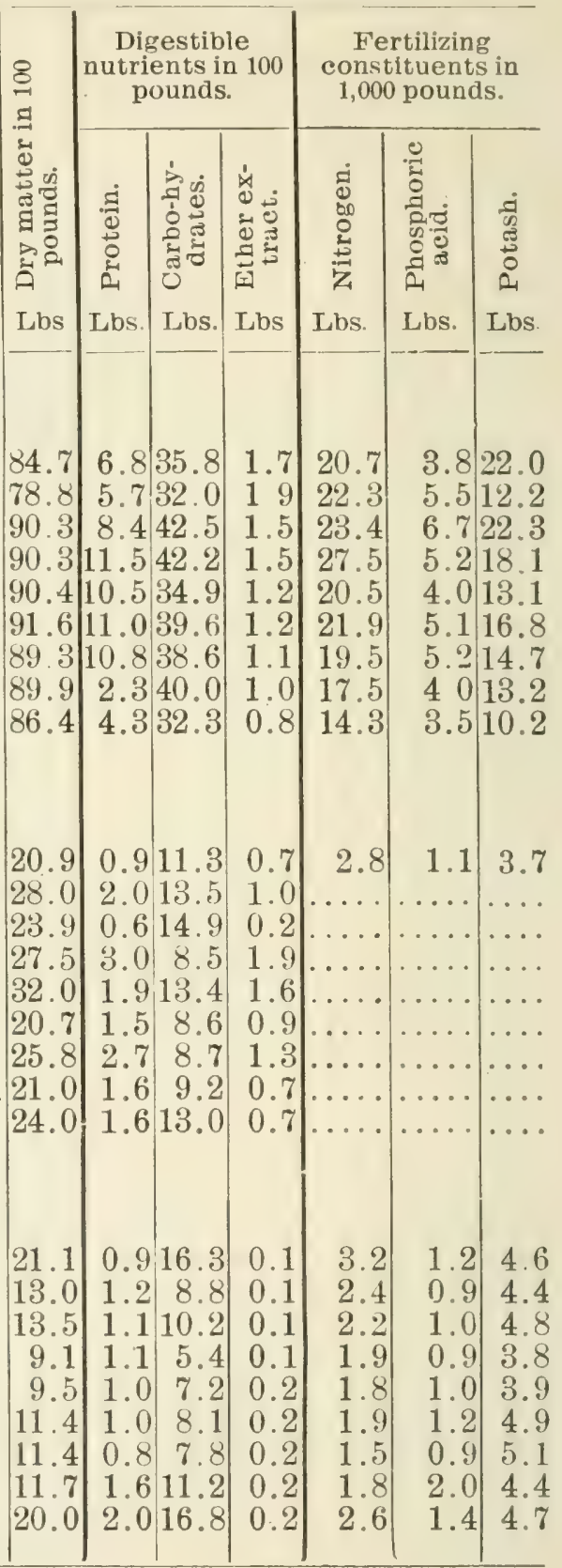

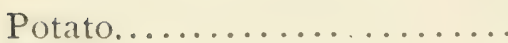

Beet, common...............

Beet, sugar...............13.5

Beet, mangel...............

Flat turnip...............

Ruta-baga.................

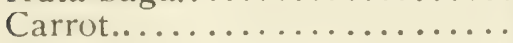

Parsnip.................11.7

Artichoke.

Silage.

Corn

............

Grass.....................

Cowpea vine...............

Boja bean-......................

Corn and soja bean..........

\section{Roots and tubers.}


'TABLE V. Digestible nutrients and fertilizing constituents.-Con.

\begin{tabular}{|c|c|c|c|c|c|c|c|}
\hline \multirow[b]{2}{*}{ Name of feed. } & \multirow{2}{*}{ 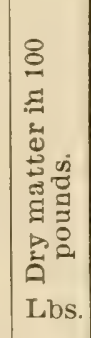 } & \multicolumn{3}{|c|}{$\begin{array}{c}\text { Digestible } \\
\text { nutrients in } 100 \\
\text { pounds. }\end{array}$} & \multicolumn{3}{|c|}{$\begin{array}{l}\text { Fertilizing } \\
\text { constituents in } \\
1,000 \text { pounds. }\end{array}$} \\
\hline & & 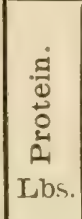 & 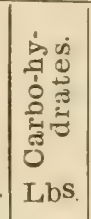 & 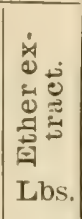 & 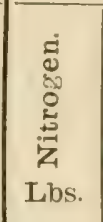 & 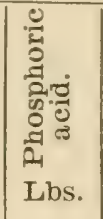 & 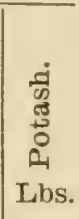 \\
\hline 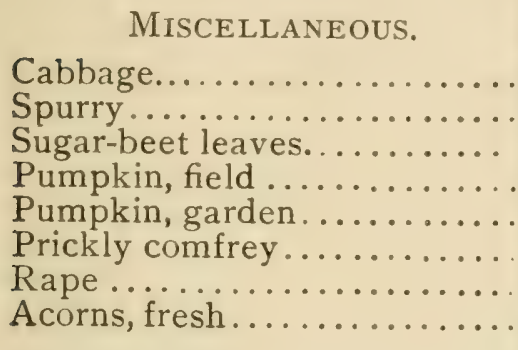 & $\begin{array}{r}15.3 \\
20.0 \\
12.0 \\
9.1 \\
19.2 \\
11.6 \\
14.0 \\
44.7\end{array}$ & $\begin{array}{l}1.8 \\
1.5 \\
1.7 \\
1.0 \\
1.4 \\
1.4 \\
1.5 \\
2.1\end{array}$ & $\begin{array}{r}8.2 \\
9.8 \\
4.6 \\
5.8 \\
8.3 \\
4.6 \\
8.1 \\
34.4\end{array}$ & $\begin{array}{l}0.4 \\
0.3 \\
0.2 \\
0.3 \\
0.8 \\
0.2 \\
0.2 \\
1.7\end{array}$ & \begin{tabular}{r}
3.8 \\
3.8 \\
4.1 \\
\hdashline 1.1 \\
4.2 \\
4.5 \\
$\cdots$
\end{tabular} & $\begin{array}{r}1.1 \\
2.5 \\
1.5 \\
\cdots \\
1.6 \\
1.1 \\
1.5\end{array}$ & $\begin{array}{l}4.3 \\
5.9 \\
6.2 \\
0.9 \\
0.9 \\
3.5 \\
\ldots\end{array}$ \\
\hline 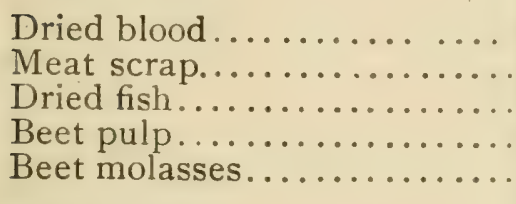 & $\begin{array}{l}91.5 \\
89.3 \\
89.2 \\
10.2 \\
79.2\end{array}$ & $\begin{array}{r}52.3 \\
66.2 \\
44.1 \\
0.6 \\
9.1\end{array}$ & $\begin{array}{r}.0 \\
.3 \\
.0 \\
7.3 \\
59.5\end{array}$ & $\begin{array}{r}2.5 \\
13.7 \\
10.3 \\
\cdots .0 \\
.0\end{array}$ & $\begin{array}{r}135.0 \\
113.9 \\
77.5 \\
1.4 \\
14.6\end{array}$ & $\begin{array}{r}13.5 \\
7.0 \\
120.0 \\
0.2 \\
0.5\end{array}$ & $\begin{array}{r}7.7 \\
1.0 \\
2.0 \\
0.4 \\
56.3\end{array}$ \\
\hline 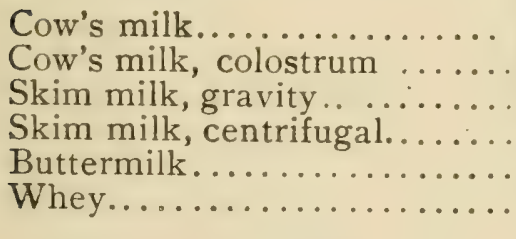 & $\begin{array}{r}12.8 \\
25.4 \\
9.6 \\
9.4 \\
9.9 \\
6.6\end{array}$ & $\begin{array}{r}3.6 \\
17.6 \\
3.1 \\
2.9 \\
3.9 \\
0.8\end{array}$ & $\begin{array}{l}4.9 \\
2.7 \\
4.7 \\
5.2 \\
4.0 \\
4.7\end{array}$ & \begin{tabular}{|l|}
3.7 \\
3.6 \\
0.8 \\
0.3 \\
1.1 \\
0.3
\end{tabular} & $\begin{array}{r}5.3 \\
28.2 \\
5.6 \\
5.6 \\
4.8 \\
1.5\end{array}$ & $\begin{array}{l}1.9 \\
6.6 \\
2.0 \\
2.0 \\
1.7 \\
1.4\end{array}$ & $\begin{array}{l}1.8 \\
1.1 \\
1.9 \\
1.9 \\
1.6 \\
1.8\end{array}$ \\
\hline
\end{tabular}




\section{CHAP'TER VIII.}

SILOS AND SILAGE.

A silo is an air-tight receptacle for preserving green feeds in a succulent condition. Feed thus preserved is known as silage. Clover, cow-peas and other forage crops have been successfully made into silage, but experience has shown that the cheapest and most satisfactory silage is made from corn cut in the denting or glazing stage.

Silage is now universally recognized as one of the cheapest and most indispensable feeds in economical milk production. With the studious dairyman, it is no longer a question of, "Can I afford to build a silo," but, "Can I afford to be "without one?"

Advantages of Silage. The advantages of feeding silage may be briefly stated as follows:

I. It furnishes the cheapest roughage available upon the farm.

2. It furnishes roughage, which, in degree of succulence and palatability, more nearly approaches green pasturage than anything else to be had upon the farm.

3. Owing to its kinship to grass in succulence and palatability, it can readily be substituted for the latter during periods of drought and during late summer and fall when pasturage is nearly always inadequate.

4. It has made winter dairying a feasible and profitable business, because the silage readily takes the place of summer pasturage.

5. It furnishes a uniform feed and makes uniformly 
good feeding a possibility the year round.

6. It permits the storage of a large amount of feed in a comparatively small space.

7. Where the silo adjoins the barn it makes feeding easy.

8. It permits housing the corn crop regarciless of the condition of the weather.

9. There is practically no waste in feeding.

Io. It yields the largest amount of feed possible from the corn plant.

Size of Silo. The size of the silo is determined by the number of cattle to be fed. In general, a cow will consume about 40 pounds of silage daily; and, if fed silage 180 days in the year, she will consume a total of 7,200 pounds. At this rate 20 head of cattle would consume 72 tons. But it should be remembered that it requires a silo of not less than 80 tons' capacity to hold 72 tons of well made silage. A cylindrical silo of this capacity will measure about I4 feet in diameter and 28 feet in height. (See appendix.)

A good rule to follow in determining the size of a silo is to estimate the amount of silage that is to be fed during the year and assume a weight of 40 pounds for every cubic foot of silage.

Silos should not be built too large. Where i 50 to 200 tons of silage are required, it is far better to put this amount of silage into two silos than into one. The height of the silo should be limited to thirty feet. Too much power is required in elevating the silage higher than this and those who have climbed high silos will be able to testify to the fact that it is not an agreeable task.

Where a silo is built with a reasonable capacity, it is 
also more restricted in diameter which permits a deeper layer of silage to be removed daily. This has the advantage of keeping the silage fresher in summer and reducing the amount of freezing in winter. Where only one silo is used, silage is frequently carried over from one year to another until the bottom part may be three to eight years old before it is finally fed.

Location of Silo. For convenience of feeding, the silo should be as near the manger as possible. It is preferably joined to the barn at one end by means of a chute, so that one can step into the silo without leaving the barn. Where the silo is thus located, it is necessary to prevent the escape of silage odors at milking time, by providing doors for closing up the chute leading to the silo.

Silos should be located to give them as much protection from cold as possible. This is especially necessary with concrete silos.

The location of silos with regard to keeping the silage from freezing has been given too little consicleration by silo builders.

Construction of Silo. Silos should be round, having the appearance of a cylinder whose height is ahout twice its diameter. They may be built of wood, stone, brick, concrete, or a combination of two or more of these. As a rule, the choice is determined by the relative cost and availability of the materials mentioned.

In building a silo four things must be kept in mind. First, it must be air-tight. Second, it must have sufficient strength and rigidity to enable it to withstand the pressure of the silage without yielding. 'Third, it must have a smooth inside surface to permit the silage to settle 
readily. And, fourth, it must be deep so that the weight of the silage will give compactness sufficient to expel the air which is held between the particles of silage.

It is desirable that the total depth of the silo be at least 30 feet. Where the ground is dry, five or six feet of this depth may be underground. When 30 feet is selected as the fixed depth, the silo can be made of the desired capacity by selecting the proper diameter, which may vary from 12 to 24 feet.

\section{CONCRETE SILOS.}

Concrete has all the (pualities sought in the construction of an ideal silo when handled in the proper manner. There are various forms of concrete silos built at the present time. Some are built of hollow blocks, some with a single solid wall, and others with a double wall and an air space between. The single solid wall has proven popular where the silo can be so located as to give it good protection from the cold of the winter.

The following is a description of two single solicl walled silos built on "Michels' Stock Farm." (See Fig. 91/2.)

The silos are each fourteen feet, ten inches in diameter (inside) and thirty feet high. The walls up to within three feet of the doors are six inches thick; from this point they gradually increase in thickness to eight inches at the doors. The doors are of the continuous kind, extending from top to bottom. The break in the silo caused by the continuous door is strengthened by running three-quarter inch iron rods horizontally across the opening at intervals of twenty-four inches. The ends of these rods are embedded in the concrete wall a distance of four inches and fastened to them are the ends of No. 5 rein- 
forcing wire. A reinforcing wire is laid every foot. The roof is made of lumber and covered with prepared roofing paper. It took three men six days to put up the silo wall including the concrete bottom.

Cost of One Silo. The itemized cost of each silo is as follows:

Labor, digging foundation.........\$I6.00

Labor, putting up the concrete wall... 65.00

Thirty-nine barrels cement at $\$ \mathrm{I} .20$ a barrel .................. 46.80

One and one-half rolls No. 5 wire at $\$ 1.65$ a roll $\ldots \ldots \ldots \ldots \ldots \ldots . . . .47$

Twenty loads gravel (distance hauled 300 yards) at 40 cents a load..... 8.00 Roof ........................ 35.00

Binding irons run horizontally across door openings $\ldots \ldots \ldots \ldots \ldots \ldots .2 .75$

Total cost of silo, without doors.... \$ 176.02

The labor in putting up the concrete work was performed by silo builders who were paid by the day and they furnished their own molds and concrete mixer. The latter was run with a one and one-half horsepower gasoline engine. No account was taken of the cost of the gasoline which, however, was small. Flowing water was run right up to the silo.

Doors. On the inside, right at the edges of the continuous opening for the doors, a depression, two inches deep and two inches wide, is made to receive the doors. This depression is made by putting a $2 \times 2$-inch stud in the mold. The doors consist of pieces of planks twelve inches wide. To prevent entrance of air where the planks join, 


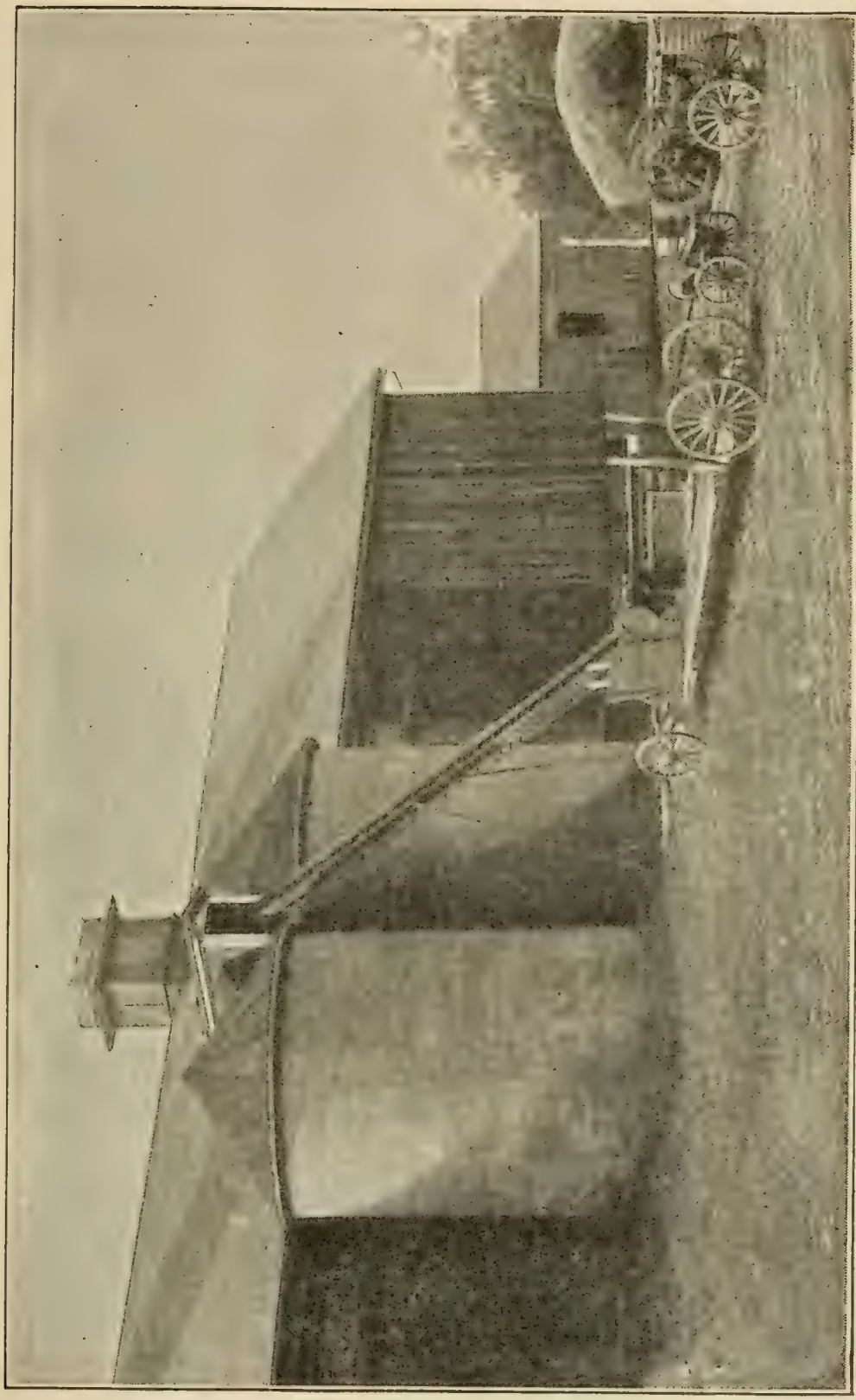

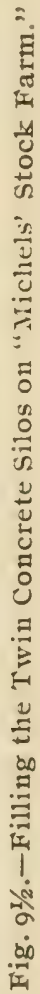


a layer of heary building paper is placed between the silage and the doors when filling the silo.

Advantages of Twin Silos. 'Two silos, if built together at one side of the barn, have an advantage also in clispensing with the building of a chute, as shown in the accompanying illustration. Both silos when placed as shown here can be filled with a single setting of the machiner.

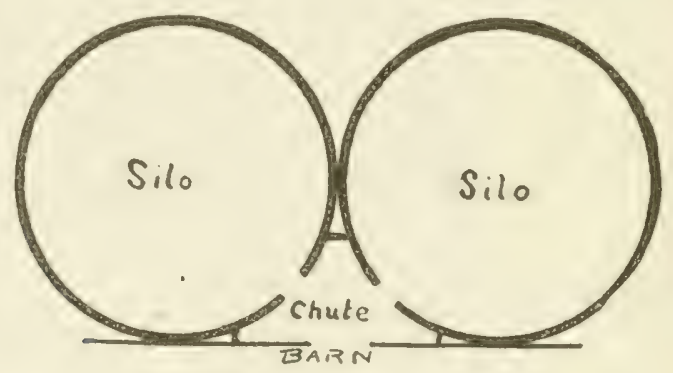

Ground Plan of Silos.

The chute acts as an exit for the foul air from the barn. The donr which connects the barn and chute is tight-fitting and slides up and down so that it can run to within a foot of the floor; or, if desired, can be closed entirely. Using the chute as an exit for the barn air will help to keep the silage from freezing because of the comparative warmth of this air. Sufficient light is provided in the silos and chute by putting a window horizontally over part of the top of the chute.

Where two silos are used one can certainly be emptied every year so that silage in no case needs to be kept longer than eighteen to twenty months. Two silos are desirable also for best results in feeding silage during the summer or early fall, as well as during the winter.

\section{CONCRETE-LINED SILO.}

Fig. Io shows a vertical section through such a silo. 
Table VI-Showing nutrients in corn plant at different stages of growth.

$$
\begin{gathered}
\text { Dry matter, } \\
\text { Stage of growth. }
\end{gathered}
$$

(tons)

Fully tasseled ....................... 0.8

Fully silked ...................... 1.5

Kernels watery to full milk ............ 2.3

Kernels glazing ...................... 3.6

Ripe ........................ 4.0

This table teaches an important lesson, and should discourage farmers from cutting young, immature corn, either for silage or soiling purposes.

Postponing the cutting until the corn has reached the denting or glazing stage also makes silage of better quality. At this stage the plant is less watery and the sugar has been largely converted into starch, thus preventing excessive fermentation and the formation of an undue amount of acid in the silage.

Filling the Silo. When the corn reaches the right stage of maturity, it should be cut at once and hauled from the field to the silo, where the entire plant, ears and all, is run through an ensilage cutter or shredder, cutting it into pieces from $\mathrm{I} / 2$ to $\mathrm{I}$ inch long. The ensilage cutters are provided with carriers which carry the silage to any height desired in the silo.

Where silos are rapidly filled, not less than two men should remain constantly in the silo, leveling and distributing the silage. This is necessary to insure uniform silage and an even settling. The silage should also be tramped, especially along the edge of the silo where, owing to the friction of the wall, it will not settle as readily as elsewhere.

In case of rapid filling it is best also to leave the silage 
to settle a day or two and then refill. After such settling there will be room for considerably more silage.

Covering for Silage. The floor and walls of the silo are air tight by construction, and where the silage has been thoroughly packitel, none should spoil at these places. At the top, however, where the silage is exposed to the air and where it is less solidly packed some of it will naturally spoil. To reduce this loss of silage to a minimum, some cheap material that will pack well, such as old, wet hay, for example, should be placed on top of the silage immediately after filling; and this should be followed by a thorough wetting so as to hasten the settling and matting process. Usually a dozen barrels of water may be run over the top of the silage to good advantage.

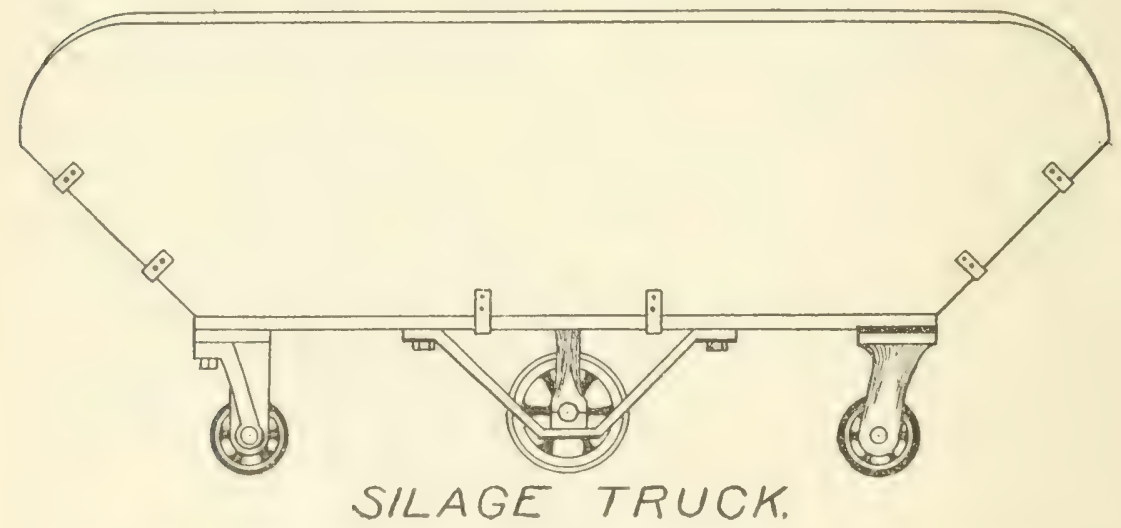

Depth of Silage that Must Daily Be Removed from Top. Owing to the constant contact of the air with the top layer of silage, it is necessary to remove a horizontal layer of silage to a depth of not less than $I^{\mathrm{T}} / 2$ inches daily to prevent any from spoiling. If this fact is kept in mind when building a silo, its diameter can be made such as to make possible the feecling of a layer of this depth daily. 
Cost of Silos and Machinery. The cost of silos varies with the cost of materials and the method of construction. An 8o-ton silo of the Gurler type can be built for about \$150. Other silos of the same capacity, but made of different materials may cost double this amount.

A moderate sized ensilage cutter that would answer for an 8o-ton silo would also cost about $\$$ r 50 .

Where some form of power must be purchased a gasoline engine is recommended because of the many other uses it may serve on a dairy farm. (See Chap. XV.)

A moderate sized ensilage cutter when not too heavily fed can be operated satisfactorily with an eight horse power gasoline engine. The cost of such an engine is about $\$ 250$. 


\section{CHAPTER IX.}

METHOD OF KEEPING RECORDS OF INDIVIDUAL COWS.

Necessity of Keeping Records. Through the efforts of experiment stations, private individuals, and Hoard's Dairyman in particular, tests have been made of hundreds of herds throughout the country, only to find that in practically all of them some cows are kept at an actual loss to their owners. The failure on the part of the owners to detect the unprofitable cows may be traced to three causes: ( I) it may be the result of reckoning with the herd as a whole, rather than the individual members composing it; (2) it may be the result of ignoring the quality of the milk; or (3) it may be due to attempts to estimate the value of the individual members by guessing at the flow of milk for a week or two when the cows are doing their best.

The lack of business method in reckoning with the herd as a whole, rather than with the individuals composing it, is too apparent to need further explanation. The same may be said with reference to the practice of ignoring the quality of the milk. Where the owner guesses the annual yield from the quantity of milk produced for a week or two during the lactation period, he is likely to err in three important respects: guessing in itself is bound to lead more or less frequently to grossly erroneous estimates; (2) yearly estimates baserl upon a few weeks' production ignore the fact that some cows yield milk eleven or twelve months of the year, 
while others produce only seven or eight months; and (3) estimates of this kind fail to consider that. some cows that yield heavily for a short time and then drop off to a medium flow, may be exceeded in total production by others that never yield heavily at any period, but whose flow is quite steady from beginning to end of the lactation period.

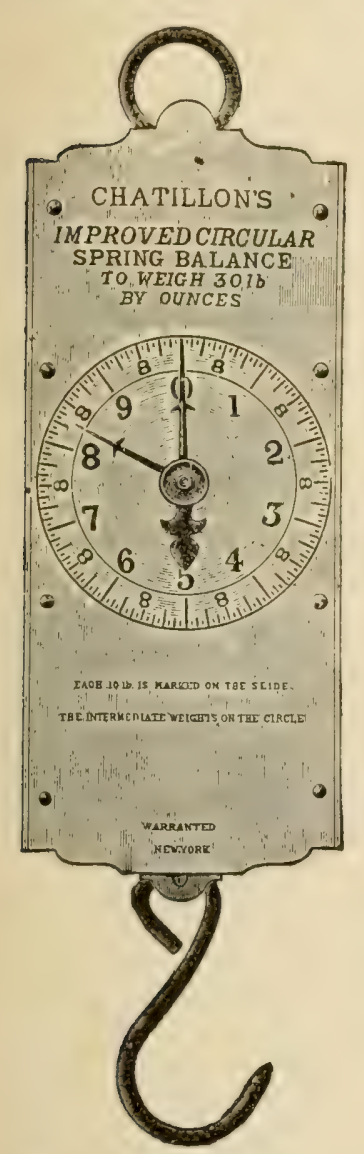

Fig. 11.-Milk Scales. Weigh 0.1 to 30 pounds.

It is evident from what has been said that there is but one method by which we can tell with certainty the value of the individual cows in a herd, and that method consists in weighing and testing the milk and keeping a record of the feed consumed for the entire period of lactation.

Daily Record of Milk. Keeping a daily record of the weight of the milk of each cow is a very simple and inexpensive task. All that is necessary is to have some form of scales and a ruled sheet of paper upon which to record the weights of milk morning and night. Fig. I I shows a cheap and convenient scales which weigh from one-tenth pound to 30 pounds. A convenient milk record sheet is shown below.

The daily weighing of the milk from each cow is valuable also in serving as a check upon the work of the milkers. A rapid shrinking in the milk is easily detected on the milk sheet and may be entirely due to 
Milk Record for Month of ...............................190

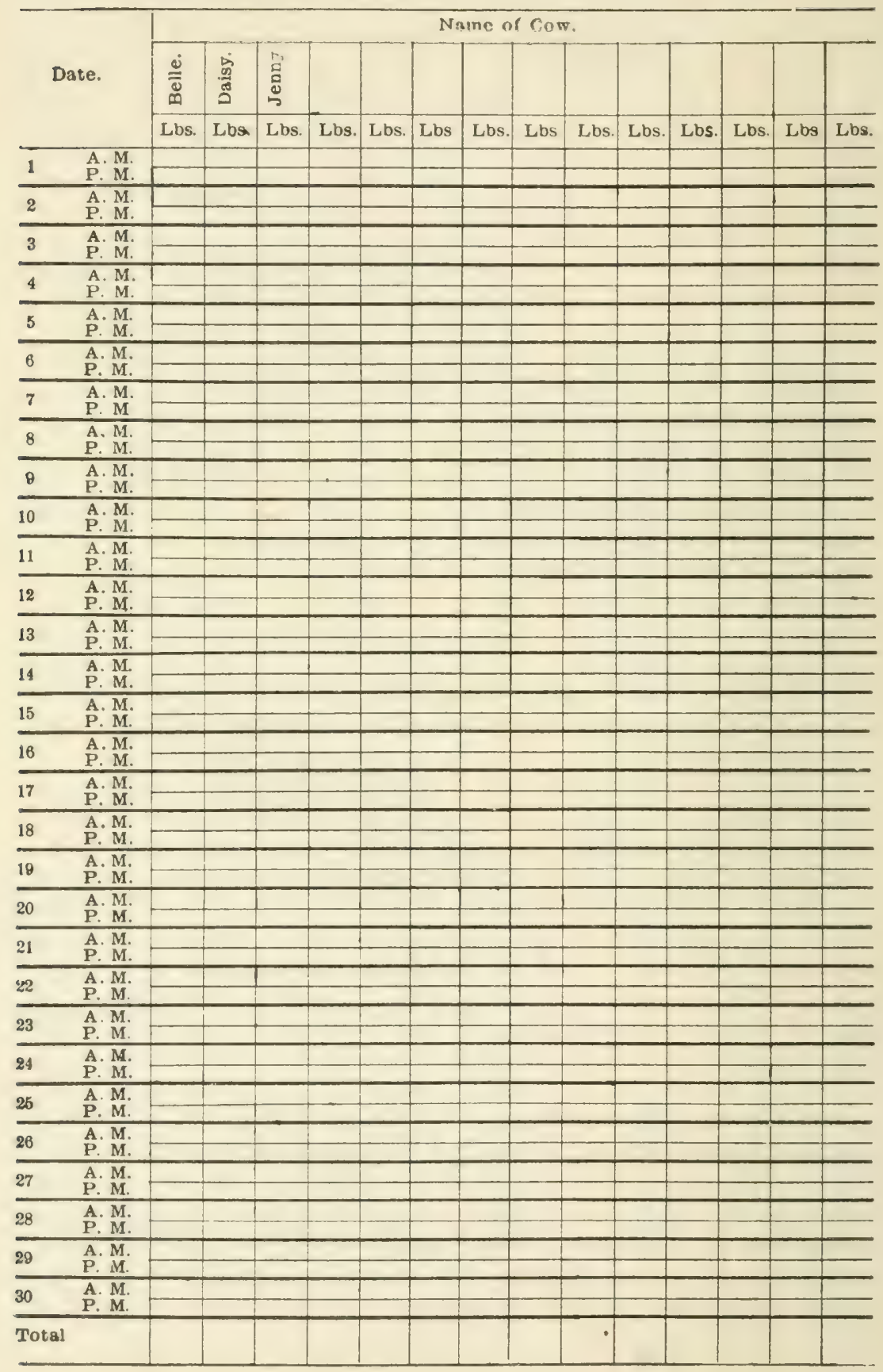


careless milking. Great daily fluctuations in the yield of milk are also in most cases the result of indifferent and inefficient milkers.

Collecting Samples of Milk for Testing. The milk from each cow should be tested about once a month during the whole period of lactation. A satisfactory way of doing this is to collect what is known as a composite sample, which consists in securing about one-half ounce of milk from each of six consecutive milkings and placing this in a half pint composite sample jar (Fig. I2) con-

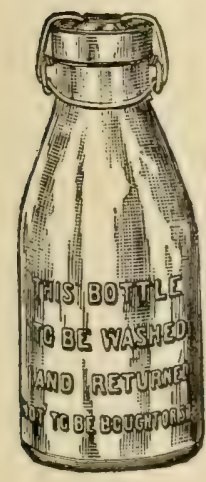

Fig. 12-

Composite Sample Jar.

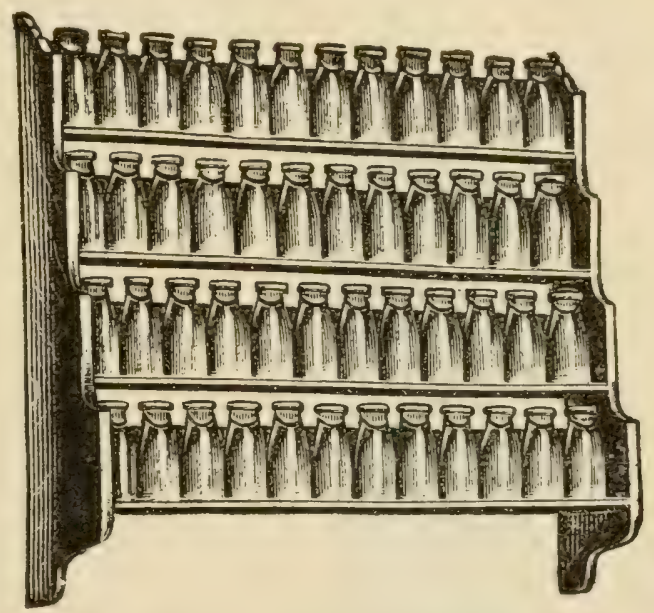

Fig. 13.-Test Bottle Rack.

taining a small amount of preservative. A test of this composite sample will represent the average per cent of butterfat for the period during which the sample was taken and will serve with sufficient accuracy as the average test for the entire month.

Each composite sample jar should be carefully labeled by placing the name or number of the cow upon it. A convenient rack for these jars is shown in Fig. I3. 
Sampling and Samplers. Immediately after milking the milk is poured from one pail into another several times and then sampled at once. The sampling may be done by either of two methods: ( I ) by means of a onehalf or one ounce dipper shown in Fig. I4; or (2) by means of a narrow tube shown in Fig. I5.

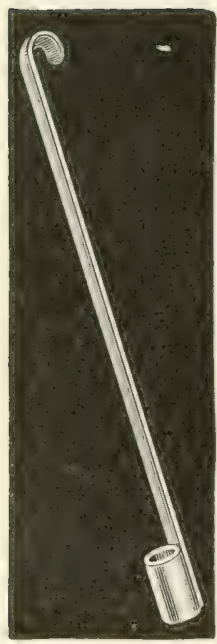

Fig. 14.Dipper Sampler.

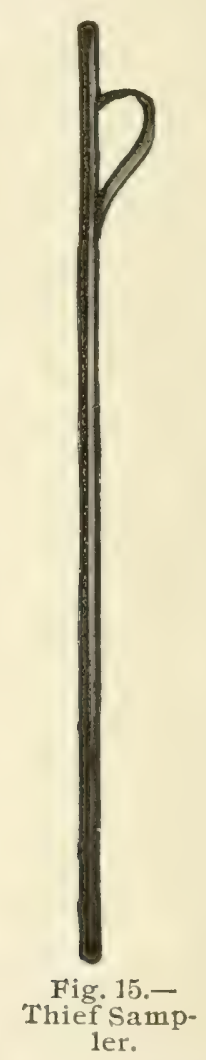

The dipper furnishes the simplest and easiest means of sampling milk. Where the milk is thoroughly mixed and where the quantity is practically the same morning and night, this method of sampling is accurate.

With the tube method the sample is always proportionate to the quantity of milk and it will draw a rep- 
resentative sample even when the milk has stood undisturbed a few minutes. This method of sampling should be employed, therefore, where there is much variation in the quantity of night's and morning's milk, or where the milk is not apt to be thoroughly mixed before sampling.

Preservatives. Milk can not be satisfactorily tested after it has soured, owing to the difficulty of securing an accurate sample. This makes it necessary to place a small amount of preservative in the composite sample jar before the sampling is begun.

The best preservatives for this purpose are corrosive sublimate, formalin and bichromate of potash. All of these are poisons and care must be taken to place them where children and others unfamiliar with their poisonous properties, can not have access to them. For convenience, the bichromate of potash and corrosive sublimate have been put up in tablet form, each tablet containing enough preservative to keep a pint of milk sweet from one to two weeks. The bichromate of potash can be procured from all druggists, and a quantity not to exceed the size of a pea should be added to each pint composite jar. A larger quantity is liable to interfere with the testing.

Testing With the Babcock Test. The method of operating the Babcock test is explained in detail in chapter XVIII.

Calculating Butterfat and Butter Yield. The monthly butterfat yield of each cow is determined by multiplying the total pounds of milk for the month by the per cent of butterfat it contains. For example, if cow No. I produced $850 \mathrm{lbs}$. of milk testing $4.2 \%$ fat, the 
total fat in this milk would equal $850 \times 4.2$, or 35.70 pounds.

Since butter contains salt, water, casein and only about $83 \%$ butterfat, it is to be expected that the yield of butter will exceed that of butterfat, provided the losses in skimming and churning are normal. The general rule in estimating the butter yield is to increase the butterfat by one-sixth. Thus the estimated butter yield of the 35.70 pounds of fat given above would equal 35.70 $X_{\text {I }}$ I-6 or 4 I. 65 . pounds. The difference between the butterfat and the actual butter yield is known as the "overrun."

Estimating the Cost of Feed. The final test of the value of a cow is the economy of production. In addition, therefore, to knowing the butterfat yield, we must also know the cost of the feed she consumed in producing it. Obviously a daily weighing of the feed, especially as concerns roughage, is not practical upon most dairy farms. If the feed which each cow receives is weighed about twice a month an approximate estimate of the feed consumed can be obtained by considering the weighed amount of feed as the average daily consumption for the month. To illustrate, let us suppose that cow No. X is doing full work on a ration consisting of 8 pounds of wheat bran, 2 pounds of cotton-seed meal, 40 pounds of corn silage and 8 pounds of corn stover. By carefully observing the volume of the weighed amounts of each feed, approximate quantities may be measured for two weeks, after which a day's feed is again weighed and the measuring continued for the remaincler of the month. In this way an approximate estimate of the quantity of feed consumed for the month can be obtained with a small amount of labor. By multiplying the total quantities of the different feeds fed during the month, by their 
respective values per ton, we obtain an approximate cost of the feed fed each cow during that period.

Yearly Record of Milk, Butterfat and Feed. At the end of each month a record of each cow's milk, butterfat test, and butterfat production, as well as an estimate of the cost of feed, should be entered upon a yearly record sheet like that shown below.

HERD RECORD FOR YEAR $190 \ldots$

\begin{tabular}{|c|c|c|c|c|c|c|c|c|}
\hline \multicolumn{5}{|c|}{ NAME OF COW } & \multicolumn{4}{|c|}{ NAME OF COW } \\
\hline Month & 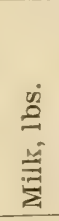 & 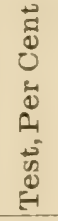 & 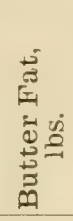 & 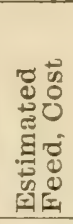 & 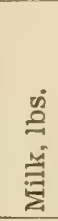 & $\begin{array}{l}\vec{d} \\
0 \\
0 \\
\dot{0} \\
2 \\
\dot{0} \\
0 \\
\text { E. }\end{array}$ & 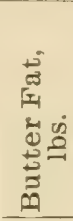 & 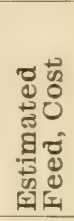 \\
\hline & & & & & & & & \\
\hline & & & & & & & & \\
\hline & & & & & & & & \\
\hline & & & & & & & & \\
\hline & & & & & & & & \\
\hline Total & & & & & & & & \\
\hline
\end{tabular}




\section{CHAPTER X.}

MILIING.

Importance of the Milking Process. The profits from a dairy herd are far more largely dependent upon the conditions under which the milk is drawn than dairymen are commonly led to believe. For example, hundreds of instances could be mentioned where milk drawn under cleanly conditions has been sold for one hundred per cent more than that drawn under uncleanly conditions. But milking from the standpoint of cleanliness is discussed in the chapter on sanitary milk production and will, therefore, not be considered here. The conditions that will be treated in the following pages are those which have a direct bearing upon the yield of milk and butterfat, and which are no less important in determining the profits from the herd than are those concerning cleanliness.

Milk Function Controlled by Nervous System. The various factors bearing upon the secretion of milk are readily understood when it is remembered that the production of milk is closely associated with the nervous organization of the cow. Whatever reacts upon her nervous system will react in like degree upon the secretion of milk.

Value of Kind and Gentle Treatment. It is owing to her high nerve development that a cow is so very sensitive to excitement, boisterousness, unkindness, rough treatment and other allied abuses which always react 
so unfavorably upon the production of milk and butterfat. Especially disastrous are the effects of abuses administered just previous to or during milking. Yet how frequently are dogs allowed to chase the cows to the stable, and how often are attendants seen with clubs which they use as aids in getting the cows into their proper places! In addition, the language and boisterousness that accompanies all this leaves no doubt that the animals are treated as offending brutes, instead of willing. sensitive mothers who are scarcely any less sensitive to harsh words than are human mothers. Make pets out of your cows by kind treatment, for kindness is never without compensation, no matter how, when or where applied.

Elaboration of Milk During Milking, If, in addition to what has been said, it will be remembered that the larger portion of the milk is secreted during the process of milking, the importance of giving a cow the very best care and treatment at this time will be fully apparent. Furthermore, the fact that most of the milk is formed during milking, materially assists in explaining why different milkers secure such varying quantities of milk and butterfat from the same cow.

Effect of Change of Milkers. From what has been said it is easily seen that frequent changes of milkers are certain to react unfavorably upon the milk and butterfat production. A cow that has become thoroughly accustomed to a certain milker will feel restless and uneasy with a new milker, which is nowhere more plainly indicated than on the milk sheet. A change of milkers, furthermore, always means a change in the manner of milking, and, therefore, a change in the stimulation of the udder. Since the stimulation of the udder by the milker is the cause of nilk secretion, it is evident that 
a change in the method of stimulation will result in a reduction of milk and butterfat production. The wise dairyman will therefore avoid changing milkers as far as possible, and will insist that the same milker always milk the same cows.

Fast Versus Slow Milking. The larger yields are secured from fast milking. This may possibly be explained upon the basis of udder stimulation. The fast milker will stimulate the udder to a greater degree than the slow milker, and the extra stimulus thus given evidently favors the secretion in the milk glands, as indicated by the actual increased production.

Importance of Withdrawing All the Milk. One of the most important factors in milking is securing all the milk at each milking; that is, milking a cow dry. Whatever milk is left in the udiler from one milking to another is not only lost to the milker, but actually acts as a check upon further secretion, so that the habitual practice of not milking cows "clean" or "dry" results in a gradual shrinking of the milk flow and an early "drying up" of the cow. Furthermore, the loss of the strippings means the loss of the very best milk. The first milk drawn from a cow usually contains less than I $\%$ fat, while the strippings may contain as much as $14 \%$.

Regularity of Milking and Feeding. The man who is looking for satisfactory returns from his dairy must make regularity a watchword. Cows must be milked regularly at a fixed time morning and night. Milking half an hour sooner or later than the fixed time interferes much more seriously with the milk yield than is commonly supposed. Not only does irregularity of milking reduce the yield of milk and butterfat, but irregularity in 
feeding leads to the same result. If, for example, cows that have been accustomed to receive their concentrates before milking, should receive them at times after milking, a reduction in the yield would be at once noticed. This is just what might be expected. Withholding the concentrates occasionally, will make the cows restless and discontented, which will sufficiently jar their nervous system to cause a perceptible drop in the milk flow. Sudden changes of feeds will act in a similar manner.

Time Between Milkings. The periods between milkings should be as nearly equal as possible. For example, if cows are being milked at six o'clock in the morning, they are also preferably milked at six o'clock at night. The more uniform the periods between milkings, the more uniform the secretion of milk, and consequently the greater the production. The time between milkings also influences the richness of the milk. If the two milking periods are not equal, it will be found that the milk of the shorter period will be the richer.

Frequency of Milking. As a rule nothing is gained by milking a cow three times instead of twice daily. In the case of exceptionally heavy milkers whose udders become unduly distended, there is, however, a distinct advantage in milking three times daily. The fact that milk from the shorter intervals between milkings has been found richer than that from the longer intervals, has driven some to the practice of milking average producers three times a day, with the hope of permanently increasing the test. While under such circumstances the test may be raised somewhat, the raise is only a temporary one.

The Value of a Good Milker. From what has already been said, it is evident that the milker plays an important 
part in the milk and butterfat production of cows. The following data secured by $\mathrm{H}$. B. Gurler from his own herd fully illustrate the importance of a good milker. Is a result of two winters' tests, Mr. Gurler found that the cows milied by the poorest milker had fallen off 9.5 pounds per head in three months, while the shrinkage of the cows milked by the best milker during the same period was only I.88 pounds per head, a difference at the end of three months of 7.62 pounds of milk per cow daily in favor of the best milker. This fully explains why some milkers are cheap at $\$ 40$ per month, while others are really expensive at less than half this amount.

The Milk Scales and Babcock Tester as a Teacher of Correct Milking. The strongest searchlight used for the discovery of leaks in the dairy herd consists of a pair of scales and a Babcock tester. These will not only tell which cows are profitable and which are not, but, if rightly employed, will also tell which milkers are paying for their salaries and which are not. Milkers should be paid according to the quality of their work, and not, as is commonly the case, according to the number of hours' service.

Milking Machines. Whether the milking machine may be considered an unqualificd success can not be positively stated at the present time. More time and tests are needed to warrant a positive statement. It may be stated, however, that many of our foremost dairymen have endorsed the milking machine as a successful milker, and this, too, after apparently thorough tests extending over periods of many months. Experiment stations also report favorable results from machine milking. 


\section{CHAPTER XI.}

\section{HERD MANAGEMENT.}

Winter Dairying. Producing the bulk of milk during the winter has four distinct advantages: (I) prices for butter and cheese are higher at this time of the year; (2) cows will milk longer when calving in the fall than in the spring; (3) labor is more plentiful at this time of the year; and (4) it is possible to feed cows cheaper during the winter than summer.

I. As a rule prices for butter are from 50 to 75 per cent higher in winter than in summer. Prices for cheese average about 50 per cent higher in winter. Indeed prices for milk in general are higher in winter than summer. It is evident that from the standpoint of higher prices alone, it is the part of wisdom to produce the bulk of the milk during the winter.

2. When cows calve in the spring, they usually have pasturage enough for a good flow of milk until about August. At this time pastures as a rule get short and cows rapidly fall off in milk. By the time stable feeding begins they have dropped off so much that they can not be brought back to a fair flow of milk even on good feed. The result is a reduced yield of milk and an early "drying up" of the cows.

When cows calve in the fall the expectation is to produce the main flow of milk during the winter and consequently the cows are well supplied with feed until they are turned out on good pasturage in the spring. In this 
way the cows maintain a good flow of milk until the best period of grazing is over. The inevitable result is an extension of the period of lactation and a greater total production of milk. An increased production is also favored by the fact that cows yield the greater share of their milk during a time when they are least troubled with flies and excessive heat.

3. It is an important advantage to be able to do most of the milking when other farm duties demand least attention. By having the cows calve in the fall, most of the milking is done during the winter.

4. An acre of land planted to corn ordinarily yields as much feed as two or three acres in pasturage. When the cows calve in the fall there is bound to be more silage produced than when the cows calve in the spring, and in so far as this is true, the cost of feed is lessened. In the case of high priced land, the saving effected by reducing the acreage onc-half or two-thirds by feeding a great deal of silage in place of pasturage must be evident.

Feeding the Bull. During the early life of the bull when he is reasonably tractable, there is no better place for him than a strongly enclosed pasture. This will supply him with the right kind of feed, give him plenty of fresh air and sunshine, and afford him needful exercise. When stall-fed, he is preferably supplied with nitrogenous roughage, such as good clean clover hay. When the roughage consists of corn stover or oat straw, the bull should be given a fair allowance of wheat bran, oats or similar concentrates. It is always desirable to supply a stall-fed bull a morlerate amount of succulent roughage, such as roots and silage.

Management of Bull. A bull should never be allowed 
to run with the herd, but is preferably kept where he is in sight of the cows. He should have a ring placed in his nose when ten or twelve months old. As a rule it is best not to tie him by the ring, but to give him the freedom of a box stall. He should be given enough exercise to keep him tractable and in good breeding condition. By all means have him dehorned.

Never trifle with a bull. He should be treated gently yet firmly. He must know he has a master. It is important to teach him early to be led with a staff fastened to the ring in his nose.

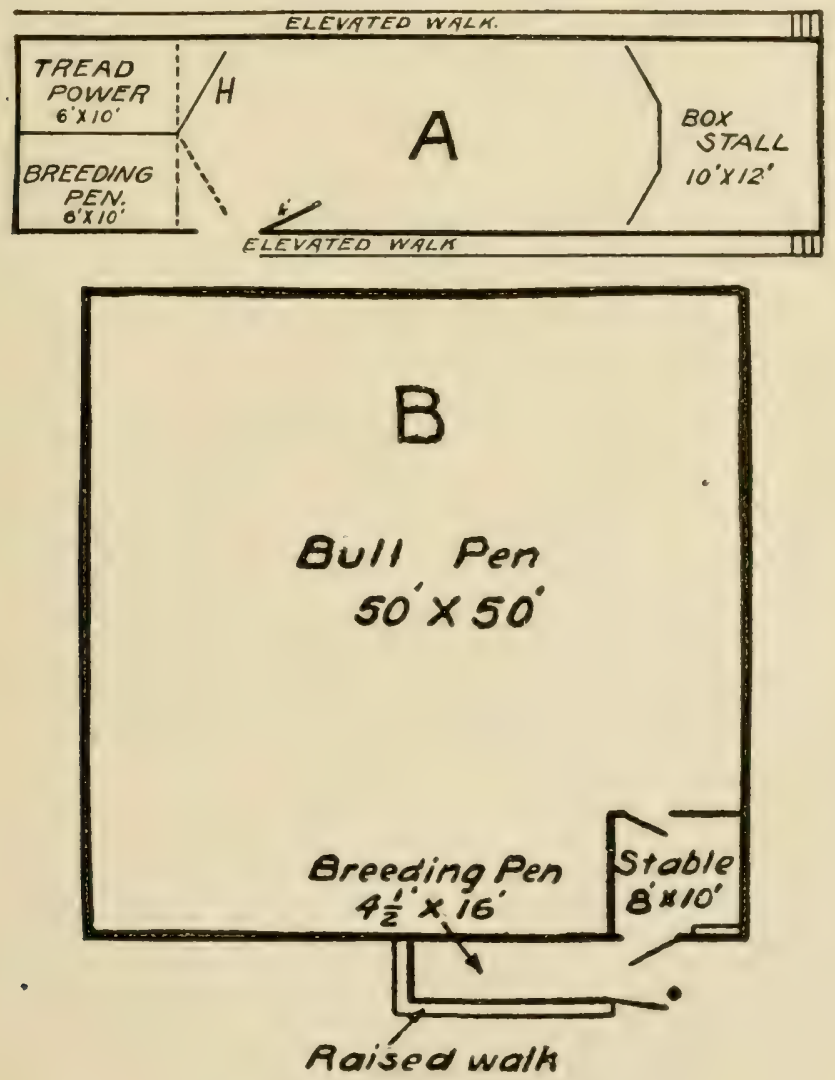

[Gig. 16.-Bull Pens. 
It is a great misfortune to have so many valuable bulls disposed of at the first signs of unruliness. When a bull has proven his value as a breeder by his own offspring, he should be, and can be, retained even though his disposition becomes threatening, by quartering him as shown in Fig. I6.

$B$ represents a pen which the author has successfully used a number of years. It consists of an enclosure with stable and breeding pen as shown in the preceding illustration (B). The bull run is fifty feet square, including the stable, and is enclosed by a solid board fence six and one-half feet high. The cow is bred in this pen by tying her to the front end and then letting in the bull by opening the stable door. The latter closes the pen when opened as shown in the cut.

While a bull can be managed in a pen such as is here described without coming in contact with him, it is best to lead him out occasionally with a stick snapped into the ring of his nose.

A represents a yard or pen essentially as recommended by the Illinois Station. At one end of the yard is located a box stall in which the bull is fed and sheltered. The other end is divided into two compartments, one containing a tread power, the other serving as a breeding pen. The gate $\mathrm{H}$ may be trirned to the right or to the left, closing either of the two compartments as may be desired.

The tread fower furnishes the means of exercising the bull. When he is wanted on the tread power, a rope is attached to his ring while he is at the manger and the attendant, who walks over the elevated narrow walk, leads him onto the power and shuts the gate behind him. While the bull is taking his exercise the attendant cleans and prepares his stall. When the buli 
is warted in the breeding pen he is similarly led along the other side of the yard. Water and feed can be supplied from the outside.

It is evident that a yard of this kind guarantees absolute safety, provides good exercise for the bull, which at the same time furnishes the power to pump water, separate the milk, and do other useful things.

An important matter in the management of a bull is to prevent excessive service. A bull should be over one year old before he is allowed to serve and the services the first season should be limited to ro or 15 , depending upon the strength and vigor of the bull. The second season he may serve 25 cows. And while some bulls have apparently successfully served as many as 40 or more cows in a season, it will be found good policy, as a rule, to restrict the number of services as much as possibbe, especially if the usefulness of the bull is to be preserved for a long time.

Breeding Rack. When heifers or small cows are bred to heavy bulls, a breeding rack should be used. This may be constructed as follows: Place two posts in the ground $33 / 4$ feet high and about $I \frac{1}{2}$ feet apart. In a line parallel with these posts and 8 or 9 feet away, place two more posts $\mathrm{I} / 2$ feet high and 20 to 22 inches apart. Connect the short and long posts with 2 Xi 2 inch planks, leaving a space of 18 inches wide between the planks at the higher end, and 20 to 22 inches wide at the lower end, which serves as the entrance. This space will fit most cows, but it is desirable to have the planks adjustable so that the space between may be increased or decreased according to the size of the cows. The arrangement as described permits the bull's front feet to rest on the planks during service. The planks should be provided 
with cleats and must be strongly supported at the middle. An adjustable stanchion is used to hold the cow in position.

Age to Breed Heifers. Heifers should be bred to drop their calves when about two years old. In cases where there is a particular lack of development in growth and general vigor, it would doubtless be a distinct advantage to have heifers drop their calves at 26,28 or even 30 months of age.

Early breeding has the effect of stunting the growth of the animal, and thus making maximum development impossible. The heifer that is bred at one year of age is obliged to turn a portion of the feed that is naturally intended for her own development to that of the foetus. After the calf is dropped a still larger portion of the feed intended for her own development is utilized for the production of milk.

While the stunting effect from early breeding has its drawback, there is also danger in delaying the breeding too long. It is doubtless correctly maintained that early breeding has the advantage of early stimulating the milk giving function of the animal, and that heifers that drop their calves at, say three years old, are apt to develop a beefy tendency at the expense of the dairy tendency.

It is evident that this matter calls for a great deal of judgment. If a heifer leans toward the beefy tendency, doubtless it is policy to breed her rather young. If, on the other hand, there is a complete absence of a beefy tendency and an indication of a slow development and delicacy, no one would question the wisdom of breeding such an animal relatively late.

Record Date of Service and Calving. This is important for three reasons: (I) it enables one to confine cows 
in box stalls about a week before calving; (2) it enables one to tell the exact length of time cows have carried their calves, and therefore makes possible the detection of premature births and abortions; (3) one knows the exact length of the lactation period of each cow.

I. Where the date of service is not known, it frequently happens that cows are obliged to calve in their stalls or stanchions. Such unfortunate occurrences should be prevented by confining cows in roomy box stalls not less than a week before they are due to calve.

2. In case the date of service is not known, it is perfectly possible for cows to drop living abortions which the owner may mistake for mature calves. Where the abortion is of a contagious nature the danger of mistakes of this kind is too evident to need further explanation.

3. Most dairymen appreciate the value of persistent milkers, yet comparatively few are able to tell, even approximately, the length of the lactation period of the different cows in the herd. The only certain way of knowing how long each cow produces milk after calving is to record the date of calving.

"Drying Off" Cows. As a rule it is desirable to have cows "go dry" at least a month before calving. This has the effect of increasing the supply of nutrients for the development of the foetus, as well as enabling the cow to store up some reserve energy which will put her in better physical condition for the act of parturition and the period immediately following.

Where it is desirable to hasten the "drying off," the following method will be of value. Start drying off by not milking the cow clean. This will quickly reduce the flow to a point where it is safe to skip every other milking. After a few days, or perhaps a week, the 
milk will be sufficiently reduced to warrant milking only every other day. A very short time after this, as a rule, it will be found safe to stop milking entirely.

In case of very persistent milkers, it is better to milk them close up to, if not up to, calving, rather than force the "drying off" process too much.

Dehorning. The advantage of dehorning is now pretty generally recognized. The absence of horns makes cows more quiet and docile, and saves them many tortures that are ordinarily inflicted when the horns are retained.

The horns may be removed either by sawing them off or by cutting them off with an instrument known as a clipper. The simplest and most humane method of removing horns, however, is the use of caustic potash soon after the calf is born. The Author has dehorned a great many calves by this method which is briefly described as follows:

When the calf is 24 to 36 hours old, clip the hair from the invisible horns or buttons and rub them with a stick of caustic potash. The potash should be kept in an air-tight bottle until ready for use. As soon as removed from the bottle, the upper part of the stick should be wrapped with a piece of paper to prevent its burning the hand. After a few minutes' exposure to the air the stick becomes moist. As soon as this becomes noticeable, rub the exposed end of the stick over each button for a minute or two, or until the spot begins to look reddish or sore. If the calf is examined twelve hours later, a scab will be found where the potash was applied. showing that the potash has gradually eaten its way into the button and thus destroyed it. Care should be exercised not to allow the potash to touch any part but 
the miniature horn, as a drop on the flesh would cause unnecessary pain.

Cleanliness, Regularity and Kind Treatment. The subject of cleanliness is fully discussed in the chapter on Sanitary Milk Production. The importance of regularity and kind treatment are fully considered in the chapter on Milking.

Warm Housing. On account of their general spareness of flesh, cows have little protection for their vital organs and are therefore peculiarly susceptible to cold. For this reason, warm housing during the winter season is a matter of the highest importance. It matters little how good a dairy machine a cow may be or how well she may be fed, the returns from her will be unsatisfactory if she is compelled to shiver in her stable the larger portion of the winter and is possibly even denied the protection of a stable during the cold drizzling rains which usually precede and follow the severe cold of the winter.

Cows in Heat. Cows, while in heat, should be kept separate from the rest of the herd to avoid the usual disturbances incident to kseping them with the herd. 


\section{CHAPTER XII.}

REARING THE DAIRY CALF.

Prenatal Development. The making of a strong, vigorous, healthy calf begins before it is born. Unless the pregnant mother is furnished with a sufficient amount of good, wholesome feed, rich in ash and protein, the foetus must necessarily suffer retarded development. Not only should the pregnant cow be supplied with the proper nutrients for the development of bone and muscle in the foetus, but the ration should be such as will keep her in the best physical condition, which requires some succulent roughage and grain rather laxative in character. (See page 42.)

Time the Cow Should Suckle the Calf. As a rule it is best to remove the calf from its mother before it is three days old. The early removal of the calf has several important advantages:- (I) it prevents to a great extent the excitement attendant on separating an older calf from its mother; (2) it renders it easier to teach the calf to drink from a bucket; (3) it permits regularity of milking from the start; and (4) it makes possible at the outset to milk the cow "clean" at each milking. Calves never feed regularly, nor do they suck heavy milkers dry at any time. The result is a continual residue of milk in the udder which acts as a check to the secretion of this substance and leads to an early shrinkage in the milk yield.

In cases of caked and inflamed udders it is best, however, to allow the calf to suckle the cow longer than 
the time stated, since this has a tendency to hasten the disappearance of such trouble.

Feeding the Young Calf. The first mi1k drawn after calving has purging properties which nature has provided for the purging of the calf. It is important, therefore, that the calf receive this milk which is known as colostrum.

As soon as removed from the cow, the calf should be taught to drink from a clean bucket. It should be aided in this for a day or two by holding the tip. of a finger in its mouth. The milk should be fed as near body temperature as possible. During the first two weeks the calf should be fed not less than three times a day, receiving eight to ten pounds of milk daily the first week, and ten to twelve pounds the second week. After the second week skim milk may be gradually substituter for whole milk, bringing the calf to a full skim milk

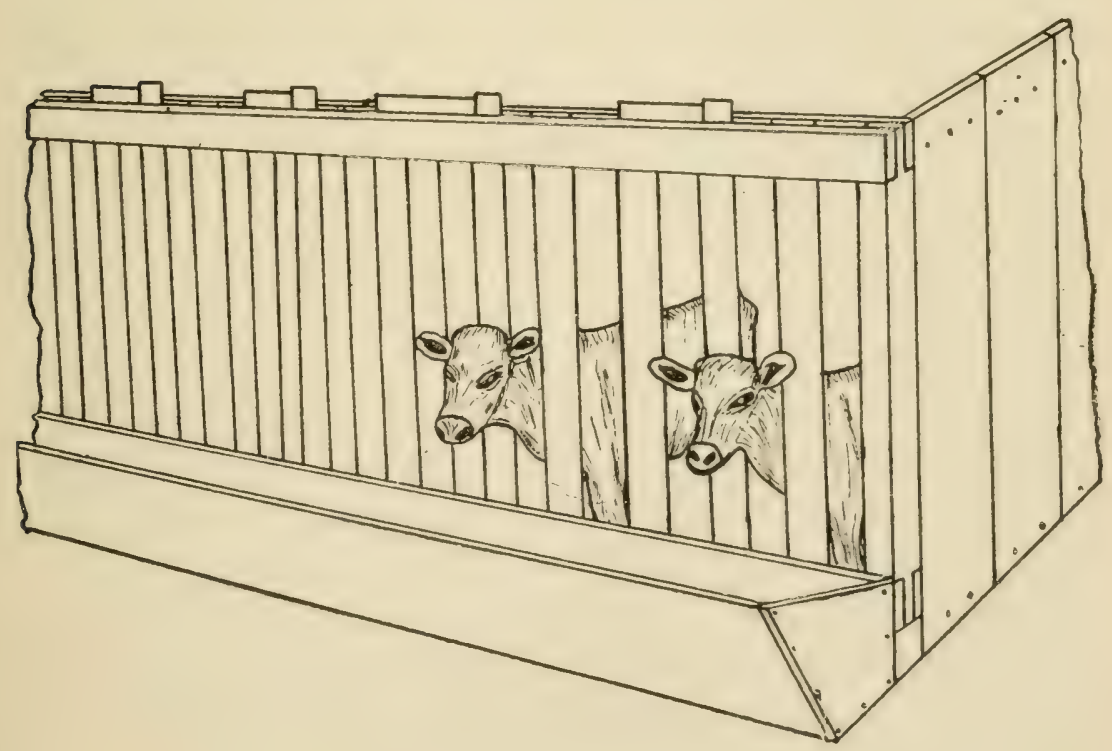

Fig. 17.-Calf Scanchions. 
feed at the end of four weeks. Beginning with the substitution of skim milk, the calf should be fed a handful of ground oats, corn meal, or linseed meal after each milk feed. At the age of one month, when feeding wholly on skim milk, one-half pound of grain may be fed daily to good advantage, and access should be given to good clean hay? The feed should be gradually increased with the growing needs of the animal.

Calf Stanchions. The feeding of milk to calves becomes a comparatively easy task when the calves are confined in cheap, rigid stanchions like those shown in Fig. I7. When so confined one person can feed half a dozen or more calves at the same time, and can do this with less labor than is ordinarily required to feed one calf. It is well, however, not to keep the calves in the stanchions too long at any one time, because of the rigid confinement. Calves that have formed the "sucking" habit may be confined to advantage in these stanchions during the night, especially when no small separate pens are available.

Importance of Correct Feeding. A young calf has a delicate stomach, which is peculiarly liable to be upset by the injudicious feeding of milk and skim-milk. In this respect it differs little from the very young child. The effect that usually follows the injudicious feeding of milk is a case of scours. This trouble can be obviated in a large measure by strictly observing the following precautions: First, never feed calves cold milk, but have it as near blood heat as possible; second, feed milk as fresh as possible and under no circumstances feed it when sour; third, feed milk only from vessels that have been thoroughly cleaned and scalced; and fourth, carefully avoid over-feeding. Scours or diarrhea is one of the common- 
est ailments of calves and one that leaves a great stunting effect upon their development.

While great importance attaches to the correct feeding of the calf in its early life, an ample allowance of feed of the right kind should be supplied at all times. Fattening feeds should always be avoided.

General Care of the Calf. Calves should be given all the outdoor exercise, fresh air and sunshine possible. During cold and rainy weather they should be confined in clean, dry stables with plenty of bedding. All the comfort possible should be provided for calves at all times. It is important also to see that they are not too much annoyed by flies during the summer. When changed from dry feed to pasture the change should be made gradually, or trouble from scouring is likely to be encountered. Plenty of good, pure water should be provided. The skim-milk feeding may be continued with profit for at least six months. When no pasture is available, it is desirable to feed a liberal amount of good, nitrogenous hay and only a small amount of grain. This will furnish the necessary nutriments for growth, at the same time the large amount of roughage tends to develop a large paunch in the young animal. 


\section{CHAPTER XIII.}

DAIRY BARN.

A Place Where Human Food is Prepared. In building a dairy barn it should be remembered that one is providing a place where human food is to be produced. Sanitary features should, therefore, have first consideration. Among the most important of these are abundance of light, ample ventilation and general regard to cleanli11ess.

Contrary to general belief, a sanitary barn is not necessarily an expensive barn. Indeed where everything is considered, a sanitary barn is certain to prove actually cheaper in the long run than one in which sanitation is made an entirely secon lary matter.

General Flan of Barn. This is illustrated in Fig. I8. The plan shows two box stalls at the north end, which are intended primarily for confining cows that are about to calve, but may also be used for bulls. The front end of the barn contains a milk and separator room, and a feed room. The latter contains stairs leading to the second story, which is used as a storage for hay and fodder, and also contains storage boxes for concentrates, which communicate with the feed room below by means of $8 \times 8$ inch shafts.

The stalls are arranged to have the cows face out, that is, away from each other. This has several advantages over the common plan of having the feeding alley 


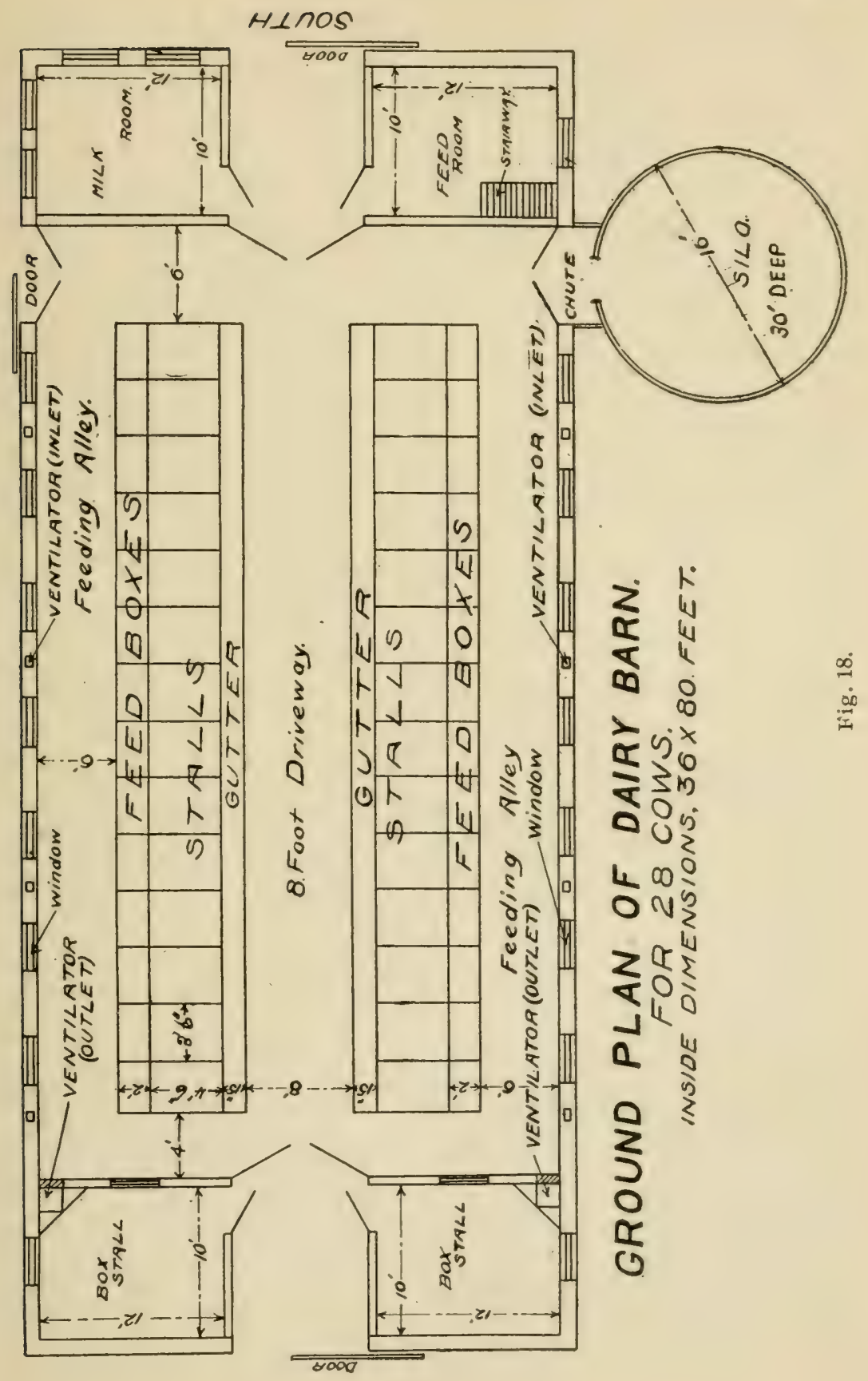


in the middle of the barn. In the first place it is more sanitary. Where the two rows of cows face each other the foul breath from each must necessarily pass from one side to the other, thus causing the cows to breathe more or less impure air. When the cows face out the exhaled air is more equally distributed through the barn and in so far reduces the amount of impurities in it immediately in front of the cows. Another advantage in facing cows out is the fact that the head is placed nearest the wall where the temperature is lowest, leaving the portion of the animal that must be most protected from the cold in the warmer part of the stable.

The silo is placed where it is most convenient for feeding. Fresh air inlets are built in the wall of the barn and two main air outlets are placed in the two box stalls, with a third at the ceiling in the middle of the barn. The driveway is such as to permit a team and wagon to enter one end of the barn and pass out at the other.

Foundation and Floor. The barn should rest upon a substantial foundation constructed of stone or concrete. On the outside of the foundation and a little below it should be placed tile drains to prevent any water from working its way under the foundation.

For sanitary reasons, only concrete floors should be permitted in a dairy barn. While the original cost may be somewhat high, in the long run they are cheapest. Aside from being easily cleaned, they also make possible the saving of all the liquicl manure, an important item to consider in the management of a dairy. To prevent the dampness commonly associated with a concrete floor it should be constructed on a cobble stone and cinder foundation underlaid with drain tile. The finish of the floor should be rather rough to prevent cows slipping on it. 
The feeding alleys, that is, the part of the floor between the mangers and the walls, should be about three inches higher than the platforms on which the cows stand. Moreover they should slope slightly toward the mangers. The platforms and driveway should also slope very slightly toward the gutters.

Light. Sunlight, because of its disinfectant action, is of prime importance in making a stable sanitary. There should be not less than four square feet of window space per cow.

Walls. Cheap and reasonably air-tight walls are secured by nailing matched lumber over good building paper on both the inside and outside of the studding, except the lower inside six feet. From the floor to a height of six feet, nail cheap one-inch lumber over building paper and put lath and concrete on this as a finish. This makes the lower portion of the wall readily cleanable as it should be. The portion of the wall above the concrete, as well as the entire ceiling, should be frequently whitewashed. The air space in the wall should be filled with some good non-conducting material. Dry straw answers this purpose very satisfactorily.

Ceiling. This should be boarded on the inside with matched lumber. The outside, or hay floor above, may be built of common, cheap lumber. When, however, no hay is stored above, the ceiling should have a dead air space, which is secured by using matched lumber and paper, both inside and outside, and filling the space between with dry straw.

Stalls and Ties. These should be arranged and constructed with the following points in view: (I) keeping the cows clean; (2) giving them as much comfort as possible; (3) preventing cows from stepping on each 


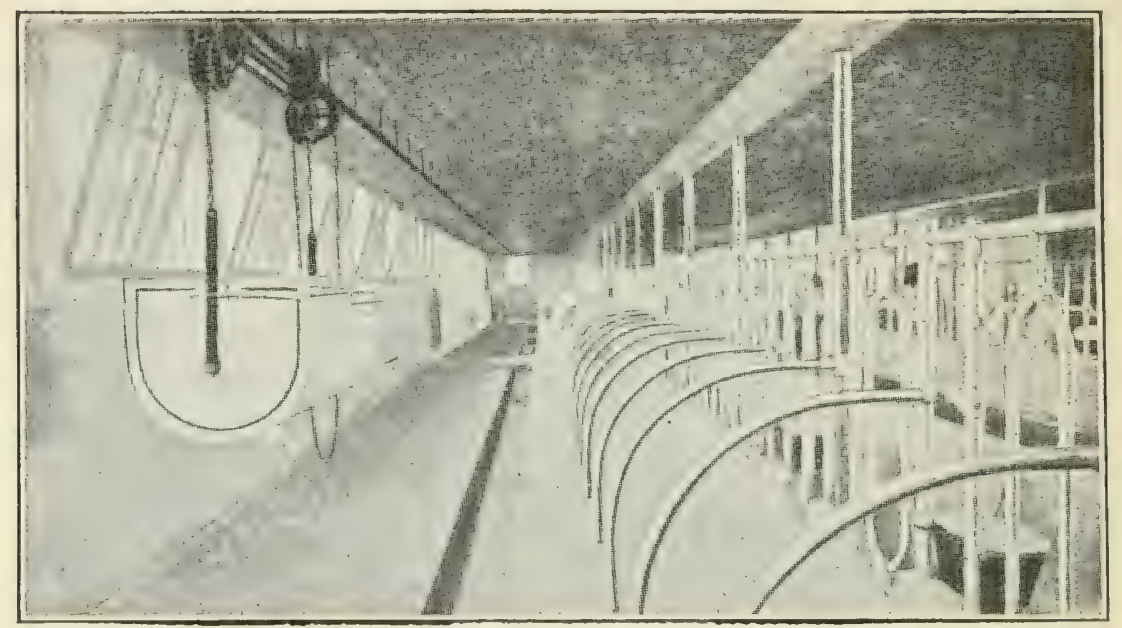

Fig. 19.-Iron Stall.

other's teats; (4) giving the milker comfort during milking; (5) having a minimum amount of surface for lodgment of dust; and (6) saving of time in tying.

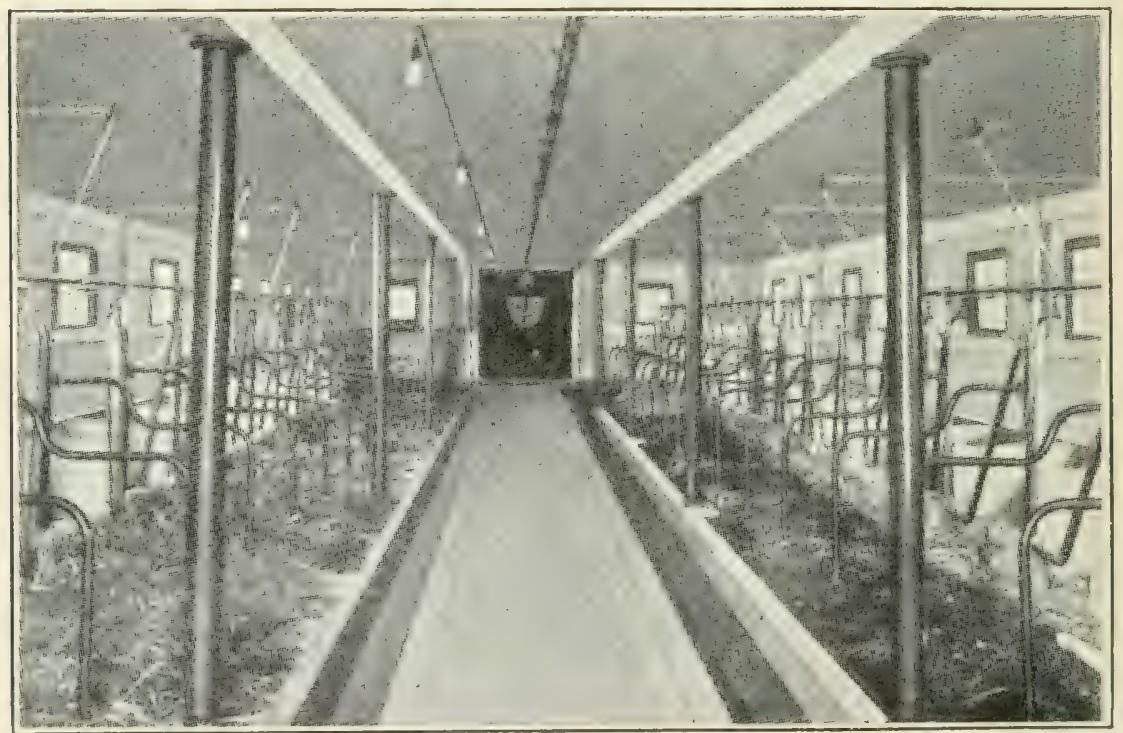

Fig. 20.-Iron Stall. 
The rope or chain is so fastened as to prevent forward or backward movements by the cows but permits free movement up and down.

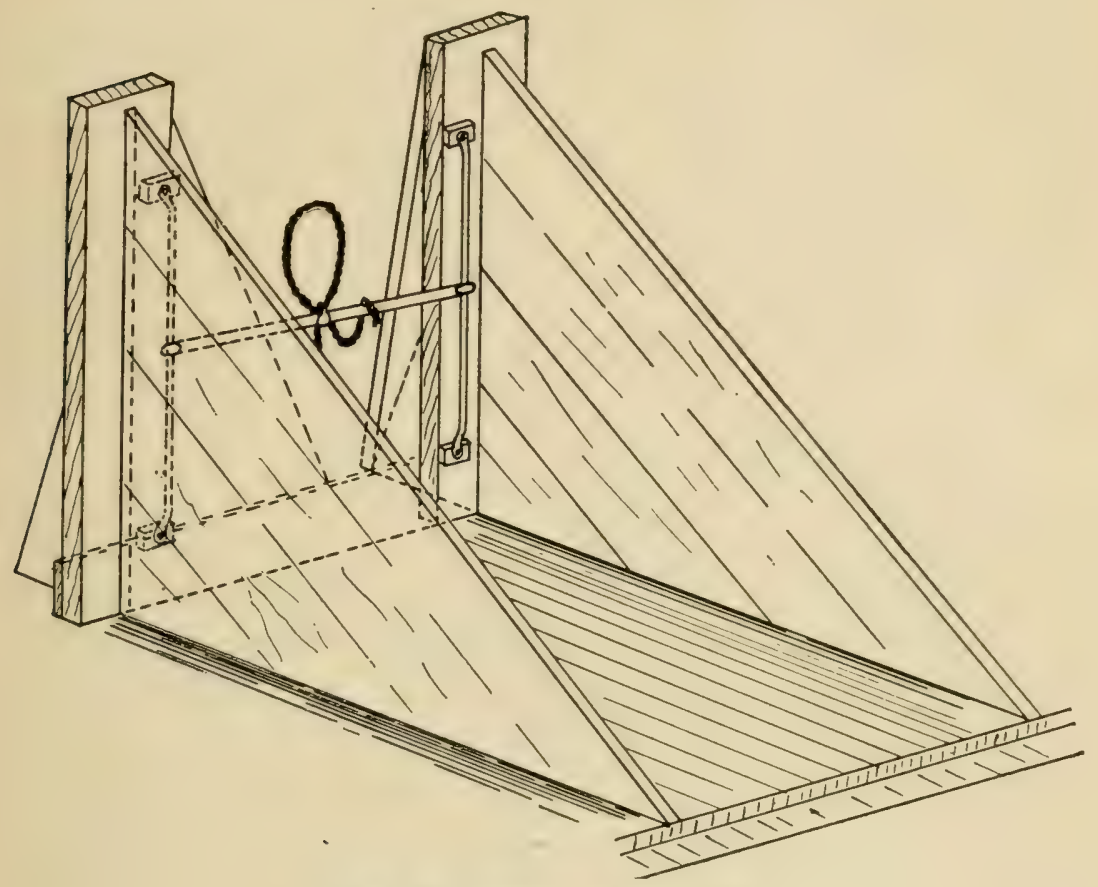

Fig. 23.-Movable Halter Tie.

Stalls like those shown in Figs. I9 and 20 have the advantage of being adjustable. The stanchion is movable, thus permitting the stall to be shortened or lengthened, according to the size of the cow. Furthermore, the swing stanchions, in dispensing with the front end, reduce the amount of stall surface, which is particularly noticeable in the stalls shown in Figs. 19, 20 and 22.

In a cold climate, it is desirable to cover the concrete floor on which the cows stand with a movable wood platform. This may be the means of preventing udder 
troubles and is certain to increase the comfort of cows during the cold season.

Size of Stalls. An average-sized cow requires a stall $3^{\mathrm{T}} / 2$ feet wide and $4 \frac{\mathrm{T}}{2}$ feet long. In nearly all herds, however, there are some cows larger and some smaller than the average. It is important, therefore, that one row of stalls be made to taper somewhat from one end to the other. For example, the stalls at one end may have dimensions $3^{\prime} \times 3^{\prime} \mathrm{IO}^{\prime \prime}$, which would nicely accommodate two-year-old Jersey heifers. From this end the dimensions may be gradually increased until they reach $4^{\prime} \times 4^{\prime} \mathrm{IO}^{\prime \prime}$ at the opposite end. The latter dimensions would accommodate large Holstein-Friesian cows.

Mangers. These should be constructed with four points in view: ( I) they should be easily cleanable; (2) they should be provided with movable partitions so as to prevent cows from stealing feed from each other; (3) they should be large enough to prevent cows from scattering their feed over the barn floor; and (4) the top should be below the cows' noses so as not to interfere too much with the circulation of the air in front of the cows.

All of the above features are embodied in the manger illustrated in Fig. 22. This manger the Author has had placed in the college dairy barn and has found it highly satisfactory in all respects. The aim was to secure a thoroughly efficient manger with as small an outlay of capital as possible. Its construction is as follows: The lower three inches are built into the concrete floor. The superstructure, which is 20 inches high, 18 inches wide at the floor and 36 inches wide at the top, is built of $3 / 4$-inch matched lumber, except the partitions which are built of $\mathrm{I} / 2$-inch lumber. Both sides of the lumber are 
planed. The partitions fit snugly into the 3 -inch concrete depression, and the entire manger is built in movable sections, each 2r feet long. The sections are held in place by means of a small hook at each end, which is fastened to the stanchion supports.

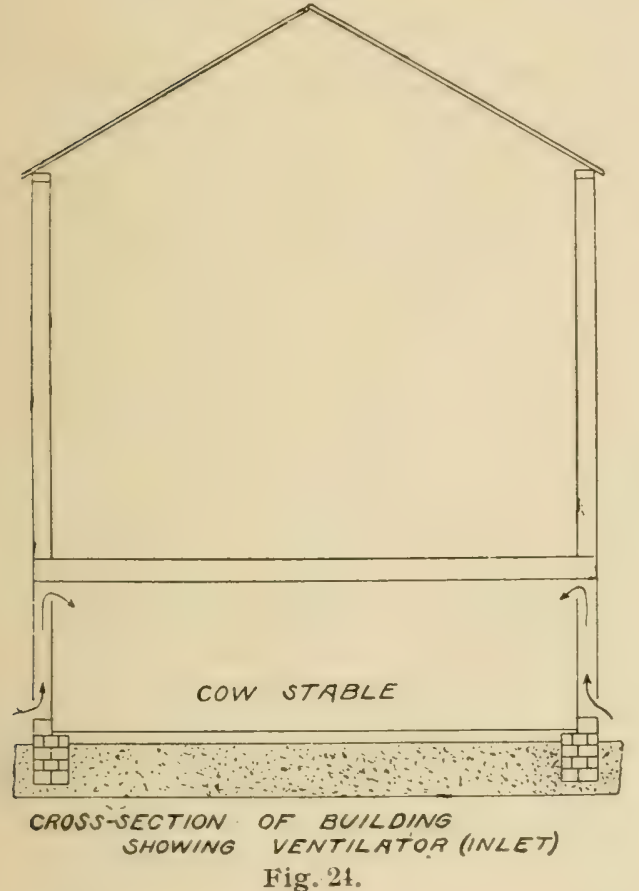

Fig. 21.

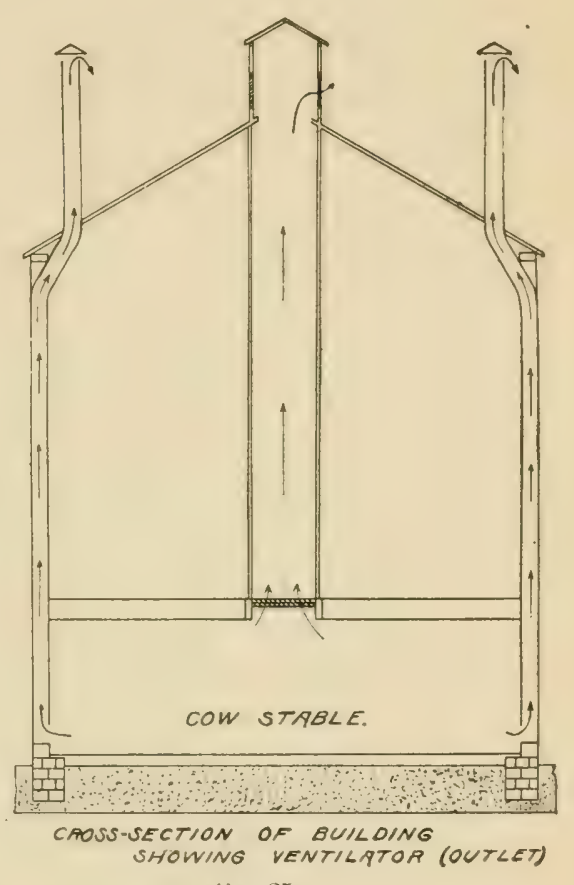

I'ig. 25.

The three-inch concrete depression makes it possible to water the cows in their stalls. When it is desired to clean the manger, the hooks are unfastened and the sections turned over, thus leaving the entire manger clear for cleaning.

Gutters. These should be about I5 inches wide and four inches deep. A greater depth is liable to injure the cows when they happen to slip into the gutter. Moreover any, extra depth means just so much more lifting 
in removing the manure. Gutters should be perfectly tight to prevent loss of liquid manure.

Ventilation. The best method of stable ventilation is that devised by F. H. King. The essential features of this method are the admission of the fresh air near the ceiling, and the withdrawal of the impure air from near the floor, as illustrated in Figs. 24 and 25. The object of admitting the cold, fresh air near the ceiling is to warm it before reaching the cows, by contact with the warm air at the ceiling. By. having the main air exits near the floor, less heat will be lost than would be the case if the exits were placed at the ceiling; besides it is argued that a considerable amount of the impurities of the air are found at the floor to which the cows' breath is constantly directed. Recent experiments seem to indicate, however, that at least so far as carbonic acid gas is concerned, most of this gas is found at the ceiling.

Whether most of the impurities are found at the ceiling or at the floor, it seems advisable to reinforce the exits at the floor, by placing a ventilator opening provided with a register at the middle of the ceiling so that some air may be withdrawn from this point. During very cold weather it may be desirable to reduce this exit to a minimum by closing the register, but during warm weather, or when it is desired to lower the barn temperature, it should be opened entirely. By having one large opening at the middle of the ceiling, there is less likelihood of removing any fresh, incoming air than would be the case if numerous smaller exits were placed near the wall and opening into the same shaft that takes up the floor air, an arrangement not infrequently recommended and used.

The number and location of inlets and outlets (except 
the outlet at the ceiling) are shown in Fig. I8. Numerous small inlets have the advantage of causing a better distribution of the cold, incoming air than could be secured by fewer, but larger openings.

On the other hand, the outlets should be few and comparatively large, which will aid in creating draft.

The fresh air intakes consist of air-tight shafts with cross-sectional areas of about 50 square inches. The shafts are built right in the wall, and open near the floor on the outside and near the ceiling on the inside. It is absolutely necessary to have the outside openings at least several feet below the inside openings, otherwise the warm inside air would rush out instead of the cold, outside air going in.

The main air outlets may be placed where they are least troublesome. In the barn plans herewith presented, they are placed in the box stalls and communicate with the main barn floor by means of registers in the wall.

The size of these registers is that of the cross-sectional area of the shafts.

To secure effective work with the King system of ventilation three things are essential: ( I) to have the ventilating shafts air-tight; (2) to have the outlet shafts extend to the highest point of the barn; and (3) to have the barn as nearly air-tight as possible.

Hay Loft. With a perfectly tight ceiling and with the hay chute in the feed room, there is no objection whatever to having a loft above the stable for the storage of roughage. Indeed such a loft has two distinct advantages: it helps to keep the stable warm and reduces the labor in feeding.

Doors. Two doors should be provided at either end of the barn, as shown in Fig. I8. The outside doors 
may be of the roller type, but on the inside it is desirable to have swing doors. The latter fit tighter and thus aid in making the barn warmer during the winter.

MISCELLANEOUS.

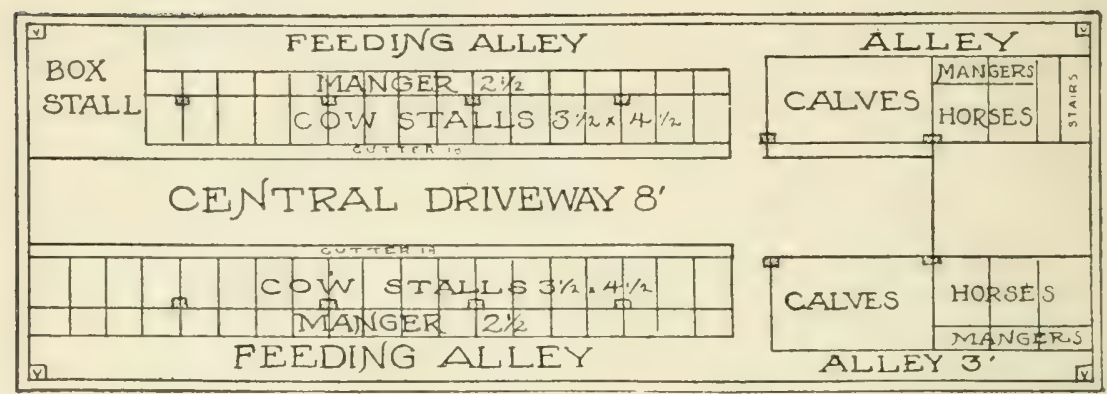

Combination Barn. (From Hoard's Dairyman.)

A "Switch" Board. 'This is an invention of Math. Nichels on whose farm it has proven an absolute protection to the milker against the cow's switch (tail) during fly season. It consists of an inch board, 8 inches wide and 4 feet long suspended from a wire. The latter runs close behind the cows and is fastened about $6 \frac{\mathrm{I}}{2}$ feet above the floor. The board slides on the wire and is pushed right opposite the milker.

Any famer can fix up a board of this kind at a trifling expense and positively protect himself from any annoyance from the cow's switch during milking.

A Cheap Home Made Stall. Stanchion supports are marle by running two 2x6-inch planks along both the bottom and top of the stanchion and supporting the whole structure by placing 2x6-inch planks upright, in front of each partition. The lower end of these upright planks is 
embedded in the concrete floor while the upper end is fastened to the ceiling.

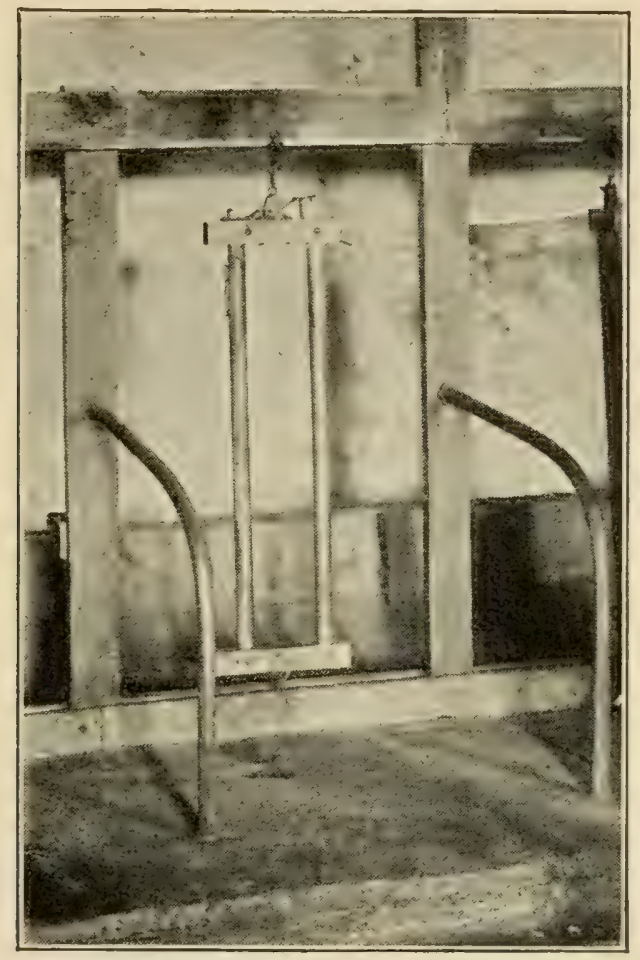

Fig. 26.-A Cheap Home-made Stall.

Partitions are made of $\mathrm{I} / 4$-inch gas pipes cut into proper lengths and then bent. One end of the pipe is double threaded and fastened to the upright planks by means of locknuts. The other end is embedded in the concrete floor. See Fig. 26. 


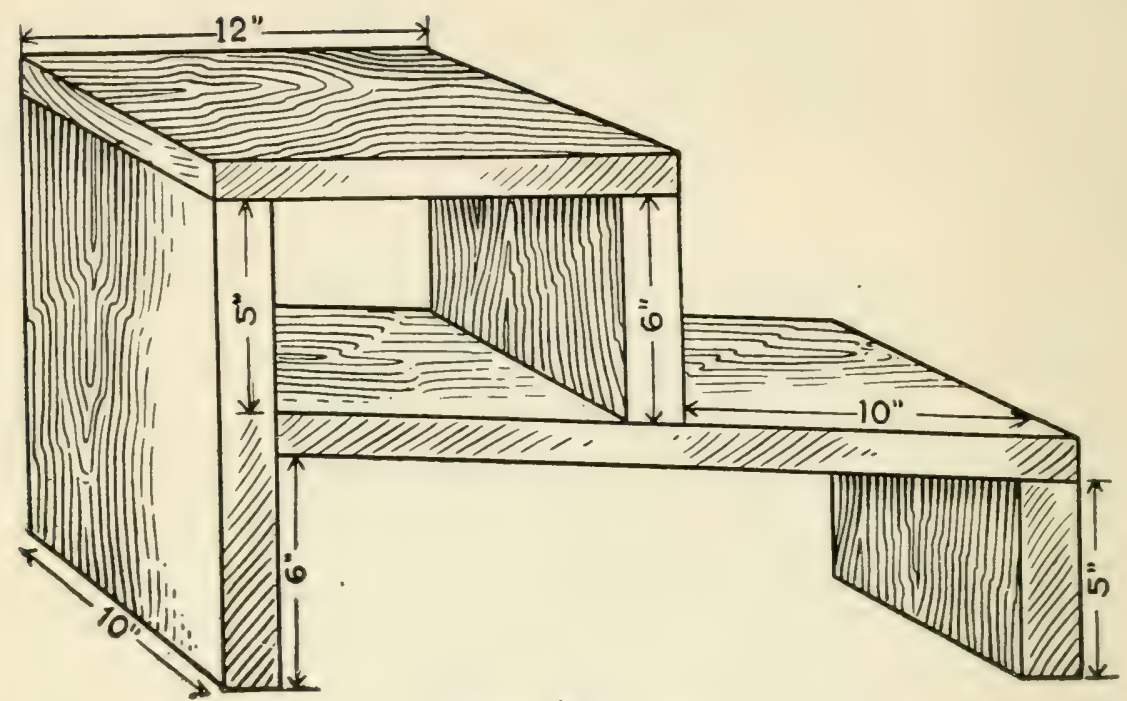

A Good Milk Stool.

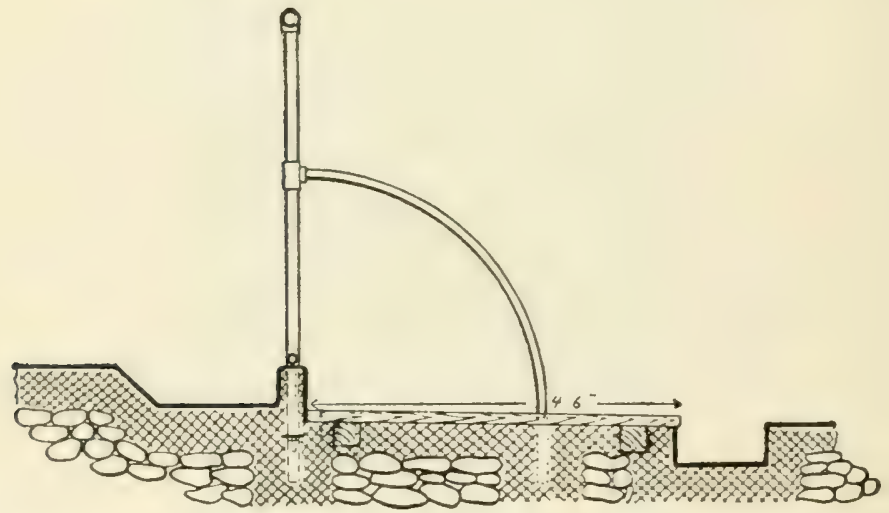

Showing Board Platform Fastened to $2 x_{4}$ 's Embedded in the Concrete.

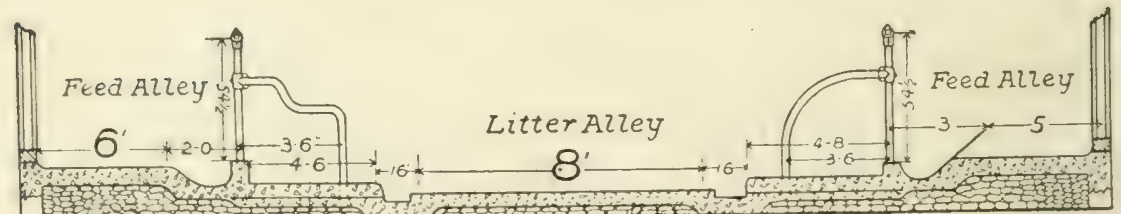
Cross-Section of Barn Floor. 


\section{CHAPTER XIV.}

HANDLING FARM MANURE.

Value of Manure Per Cow. The value of the manure from a cow depends primarily upon the character of the feed supplied her. Feeds rich in fertilizing constituents will produce manure correspondingly rich in them. On an average $75 \%$ of the fertilizing constituents in feeds are recovered in the manure. The Cornell station finds that the value of the manure from cows averaging IOOO pounds live weight, is \$29.27 per cow per year. This may be regarded as a very fair average.

Relative Value of Liquid and Solid Manure. The urine, as a rule, is much richer in fertilizing constituents than the dung. It contains more than half the nitrogen and nearly all of the potash voided by the animal. Practically all of the phosphoric acid, however, is found in the solid excreta. The fact that the larger portion of the fertilizing constituents is found in the urine, emphasizes the importance of carefully saving all this portion of the voidings.

How to Save the Urine. To save all of the liquid manure, it is necessary, in the first place, to have watertight gutters and floors. Nothing is better in this respect than concrete.

The next requirement is a sufficient amount of clean, porous bedding to absorb all of the liquid. Straw, especially if cut up somewhat, makes excellent bedding 
material. It is clean and holds a great deal of moisture. Planer sharings also answer the purpose satisfactorily.

In addition to this it is desirable to use some powdered absorbents like ground phosphate rock and gypsum. These materials not only absorb moisture but also absorb ammonia as it is liberated from the manure, thus saving valuable volatile manurial constituents and at the same time purifying the air of the barn.

Sources of Loss of Manuriál Constituents. Losses of manurial constituents may be considered under two heads: (I) those occasioned by leaching, and (2) those caused by bacterial action or fermentation processes. Where no precaution against leaching and furmentation are taken, more thian half the value of the manure is easily lost.

Loss Through Leaching. Experiments have shown that manure as ordinarily placed in a pile will lose about $50 \%$ of its value when left exposed to the weather for a period of six months. Every rain washes a certain percentage of the soluble manurial constituents away from the pile. That heavy losses occur in this way is evident from the dark liquor which runs away from a manure heap that has been exposed to the rain. Frequently for convenience of handling, the manure is piled close to the barn and directly under the eaves, where the amount of water that pours over it becomes very considerable

Losses from leaching can be entirely avoided by placing the manure in a shallow concrete pit provided with a roof. Even the concrete floor may be done away with if the ground is clayey, closely packed and so sloped that no water from without can drain into the pit. No farmer can afford to be without a covered storage for manure. 
Losses Through Fermentation. Manure is a medium exceedingly rich in bacterial* life. Many species of bacteria are at work decomposing the organic matter, breaking up higher compounds into lower compounds and accomplishing what is ordinarily designated the rotting of the manure. In the fermentation or rotting process the nitrogen compounds are broken up into ammonia, which readily escapes from the manure pile. Evidence of such escape is found in the ammoniacal odors that emanate from loosely packed manure, such, for example, as that procured from horses.

This ammoniacal fermentation can be largely reduced by packing the manure tight so as to exclude the air as much as possible. Most of the bacteria concerned in the liberation of ammonia must have air for their development, and hence their action is reduced in proportion as the air is excluded from the manure heap.

On the other hand, some species of Dacteria concerned in the liberation of nitrogen, namely, the denitrifying bacteria, require no air for their growth and development. Yet the loss from this class of bacteria is relatively so small that, while the exclusion of air favors their development, every effort should be made to keep the manure heap as air-tight as possible, so as to minimize the loss from the air-loving bacteria.

Ammonia or Nitrogen "Fixers." While the loss of ammonia from the manure heap can be materially reduced by tight packing, more or less of it is bound to be formed under the best packing possible. To prevent the escape of this ammonia it is necessary to add to the manure something which will "fix" or hold the ammonia. Materials used for this purpose are known as nitrogen or am-

* For definition of bacteria, see page 146. 
monia fixers. Ground phosphate rock and gypsum are excellent materials to use for this purpose. These materials should be added to the gutter in the barn, since they not only act as ammonia fixers, but are also excellent absorbents. On the whole the ground phosphate rock is preferable to the gypsum. The latter is sulphate of lime, and is commonly known as land plaster. Dry earth containing a great deal of humus is also valuable as an absorbent and ammonia fixer.

Hauling Manure Directly Upon the Land. If the manure can be hauled upon ground where there is no danger of its being washed away, the most economical plan is to spread it upon the land as quickly as it is formed. Under such conditions there will be practically no loss from leaching and fermentation, and, moreover, what is of no little importance, the manure is handled with the least amount of labor. As a rule it is safest to spread the manure upon some growing crop.

Manure Carriers. A convenient and labor-saving piece of apparatus upon a dairy farm is an elevated manure carrier like that shown in Fig. 27. This carrier

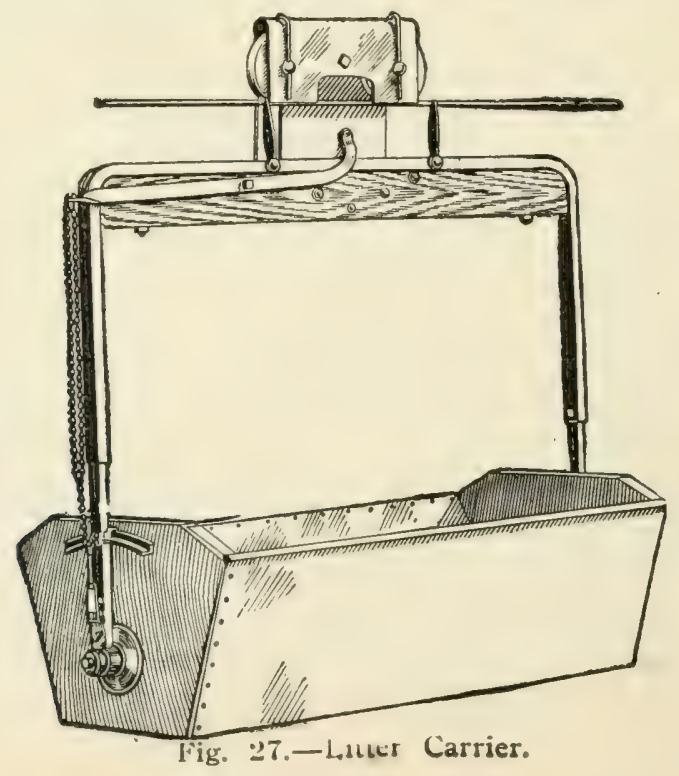


is suspended from a steel rope, and by a push of the hand it can be sent a distance of several hundred feet to unload itself and to return unaided to the barn. The unaided return is made possible by slanting the rope somewhat toward the barn. It dumps itself by means of an automatic attachment placed at the point where it is expected to unload. The convenience afforded by such a carrier is especially great during the winter, when the stable may be cleaned without leaving the barn. The carrier cable should be placed between the two rows of cows extending the full length of the stable.

Manure Spreaders: No dairy farmer can afford to be without a manure spreader. It quickly pays for itself in the saving of labor and has the additional advantage of insuring an even distribution of manure on the field. 


\section{CHAPTER XV.}

POWER ON THE FARM.

The use of some form of power upon farns has frequently been recommended in the past, but never before has its use been more urgent than at the present time. The increasing scarcity of labor, the rapid increase of hand separators and silos, and the general convenience it affords, have made power an actual necessity upon progressive dairy farms.

The kind of power needed upon a dairy farm depends upon certain conditions. If a tread power is used for exercising the bull, this will serve satisfactorily for separating milk, pumping water, and doing other light work. Where a milk house is used and butter is made upon the farm a small steam engine may be made to do any light work economically. But the use of either the tread power or the small steam engine fails to provide the necessary power for cutting corn for the silo, sawing wood, grinding feed, or doing other heavy work.

Every modern dairy farm must have a silo, and it is at silo filling time that we usually experience the greatest need for some form of power. With none of our own we are obliged to hire or borrow, a practice which often compels us to wait till the corn is past its prime. Moreover it is frequently impossible to hire power, no matter how much we may wish to do so. Where good silage is desired it should be made at the proper time, and this can be done with certainty only when we own the power.

Where power for the heavier work can not be con- 
veniently hired or borrowed, it is believed that the best solution for the farm power problem is the gasoline en. gine. Such an engine can be used for a great variety of purposes and practically every day of the year.

Besides running the ensilage cutter, cream separator and possibly a milking machine, the engine may be used to pump water, to run the washing machine, corn sheller, grindstone, saw, churn and grist mill. When placed as.

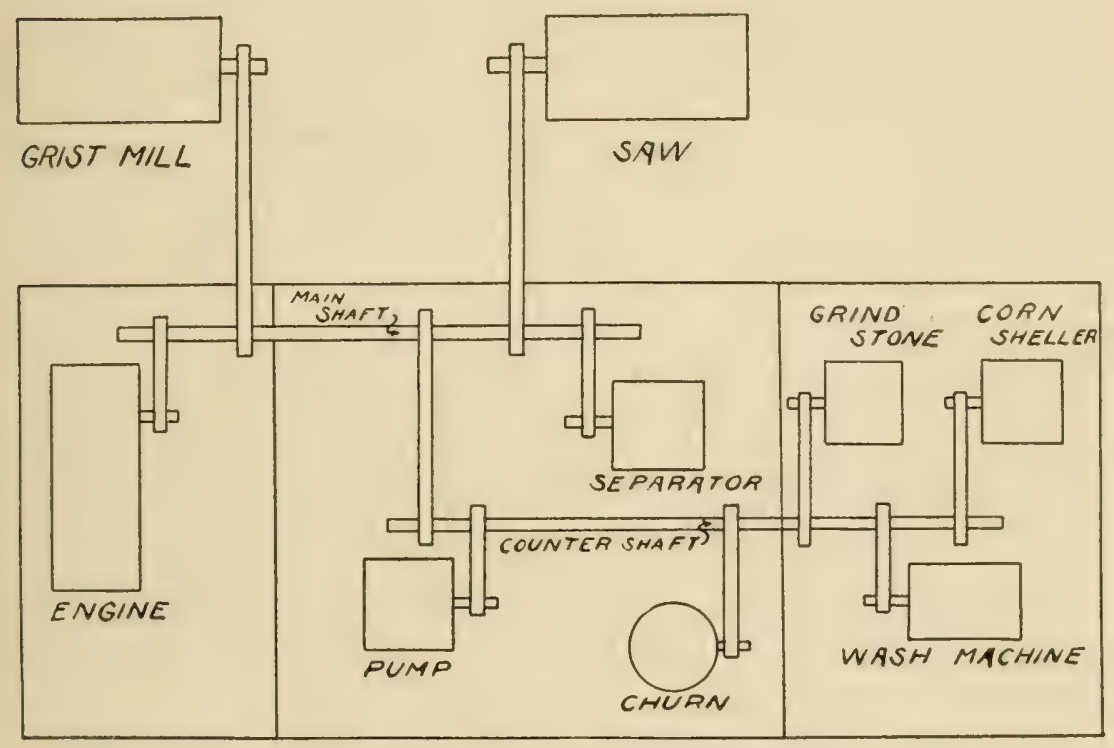

Fig. 28.-Possible Uses of Gasoline Engine.

shown in Fig. 28 several of these machines may be run at the same time.

Many dairy farmers have felt justified in going to the expense of purchasing gasoline power solely for running the cream separator. For this purpose a two-horse power engine suffices; but it would be greater economy to increase the original outlay somewhat and secure an eighthorse power engine, one that could be used for the heavier 
work of cutting ensilage and corn stover, as well as running a saw and grist mill.

This is an age of machinery, and we believe the time is not far distant when the farmer will make use of power whenever this can be made to take the place of hired labor. Power will not only afford greater convenience but will curtail the running expenses of the farm.

If, for example, we assume that one hour is required daily in running the separator, and another in pumping water for stock, the total time consumed in this work in one year would be 730 hours, or 73 days of ro hours each. At $\$ \mathrm{I}$ a day, the cost of separating and pumping would amount to $\$ 73$ a year. With a gasoline engine running the pump and separator at the same time, this work could be done in 365 hours. Allowing $6 \mathrm{c}$ per hour for gasoline and oil, which is a high estimate, the cost of doing the above work with an engine would be $\$ 2$ I.90, or less than one-third of what it can be done for with hired labor. This saving is equivalent to about 25 per cent on the investment of the engine, if used for no other purpose than separating milk and pumping water.

At ${ }^{-}$silo filling time the engine should be mounted on a suitable base near the silo, where it is expected to remain only during the filling of the silo. The remainder of the year it may be placed as indicated in the above illustration.

There are plenty of simple and smooth-running gasoline engines upon the market, and in purchasing care should be taken to get one in which these two qualities are most conspicuous.

A possible objection to the use of gasoline engines for 
dairy purposes is the trouble from gas odor where there is any tendency to laxness in the care of machinery. Where precautions are taken against leakage of gas or gasoline, and where the exhanst is properly conducted away, there should be no trouble from gas odors.

The fuel cost of running a gasoline engine may be stated as follows: When gasoline is worth Ioc per gallon, gasoline power will cost Ic per brake horse power per hour. 


\section{CHAPTER XVI}

\section{DISEASES AND AILMENTS OF DAIRY CATTLE.}

Prevention. The old adage, "An ounce of prevention is worth a pound of cure," is as true to-day as ever. The common ailments with which cattle are afflicted can be largely prevented by correct feeding, comfortable and sanitary housing, gentle treatment, and by using every precaution possible against infection from contagious diseases.

Digestive disorders are the result of injudicious feeding, and these may be the forerunner of a retinue of various other disorders. Exposure to severe cold and cold rains, and confinement in foul and unventilated stables are predisposing causes to various diseases. Many ailments are caused, either directly or indirectly, by allowing cows to lie on cold concrete floors, by chasing with dogs and by compelling them to walk and stand on slippery, highly inclined floors.

Great aid has been rendered in the prevention of diseases through the rapid development of medical science in pointing out the nature and causes of the various diseases with which cattle are afflicted. Every dairyman should have an intelligent understanding of the role which bacteria (for definition of bacteria see p. I46) play in the dissemination of diseases which could be largely avoided by proper quarantine and methods of disinfection.

Quarantine and Disinfection. By quarantining is meant the separation of the discased from the undiseased 
animals. If an animal is known to be affected with some transmissible disease, its prompt removal will usually spare the rest of the animals in the herd from the disease, especially if such removal is accompanied by proper methods of disinfection. The latter refers to the destruction of the causal agents of the disease by the use of germicides or disinfectants, substances which have the power of killing bacteria and allied organisms.

Disinfectants. The following is a list of well-known disinfectants:

I. Boiling water applied for 20 minutes.

2. A 5 per cent solution of carbolic acid.

3. A 2 per cent solution of zenolium.

4. A 2 per cent solution of chloro-naptholeum.

5. A 5 per cent solution of copper sulfate.

6. A solution of $\mathrm{I}-2000$ of mercuric chloride.

7. A 2 per cent solution of creolin.

8. A I-IOOO solution of chlorid of zinc

Purgatives. A purgative is a substance used to induce action of the bowels. Among the common purgatives the following may be mentioned: I to 2 pints of raw linseed oil; a mixture of I pound of Epsom salts and $I$ to 2 ounces of ginger dissolved in 2 pints of warm water; I pound of Glauber salts dissolved in water; or I pint of castor oil.

As a rule the best thing to do at the first signs of illness, such as loss of appetite, failure to chew the cud, dull eyes, dry muzzle, parched skin, rough coat, etc., is to administer a good purgative. This alone is frequently sufficient to relieve the trouble. 
MILK FEVER.

Causes. Overfeeding, lack of exercise, impure air, constipation, and drinking cold water are common causes of milk fever. Withdrawing all the milk from the udder during the first 24 hours after calving is claimed to be conducive to the disease. Furthermore, heavy milkers are far more subject to the disease than medium or small milkers.

Symptoms. Restlessness followed by a weakening of the muscles, causing the animal finally to stagger and fall. The cow usually lies on her breast bone with her head completely drawn around to one side. The udder becomes soft and empty, pulse weak and rapid, the temperature falls below normal, and the animal may become completely unconscious.

Treatment. Fortunately there is available now a very simple, sure, and inexpensive treatment for milk fever. The treatment consists in filling the udder with sterile air by means of a syringe which draws the air through a tube containing absorbent cotton. Such a syringe can be obtained at very small cost from the manufacturers who advertise extensively through the dairy press, and every dairyman should possess one so as to be prepared to meet emergencies promptly.

Before injecting the air, the hands, teats, udder, and the tube that is to be inserted into the teats, should be carefully disinfected. This done, each quarter of the udder is thoroughly inflated with air, kneading and rubbing the udder as much as possible during the process to secure a thorough and rapid diffusion of the air. As soon as each quarter is filled, a wide band is tied around the top of the teat to prevent leakage of air. These 
bands should not be drawn any tighter than necessary and may be removed soon after the cow gets on her feet. Repeat the treatment if necessary.

The treatment above described usually brings relief within a few hours. In a number of emergencies cows have been successfully treated by pumping unfiltered air into the udder with a bicycle pump; but this is liable to result in serious infection of the udder and should be practiced only in an emergency.

The injection of a gallon of warm, soapy water into the rectum is also desirable. Never administer drenches when the animal is partially unconscious.

\section{ABORTION.}

By abortion is meant the premature birth of the calf. Two forms of this ailment are common: (I) contagious abortion caused by bacteria; and (2) accidental abortion caused by a serious nervous shock. The latter may result from external or internal injuries, drinking cold or stagnant water, bad nutrition, exposure to inclement weather, impure atmosphere, and various constitutional diseases. Whenever abortions occur apparently without cause, they should be treated as contagious.

Contagious Abortion. This is a very menacing disease among dairy cattle. It is caused by bacteria which find their way into the reproductive organs. The disease can be successfully combatted only by rigid methods cf disinfection and prompt quarantining of the aborting animals. The dead offspring, afterbirth, and stable litter should at once be burned, or buried and covered with quick lime. The stalls and walls should be washed with a I-IOOO solution of corrosive sublimate, while the floor may be disinfected with a liberal amount of quick lime. 
The ragina and uterus should be thoroughly disinfected daily with chlorid of zinc, creolin, or corrosive sublimate solution of proper strength until the cow ceases discharging. The same antiseptic treatment should be applied frequently to the external genitals and adjacent region of uninfected cows. If the afterbirth is retained longer than 24 hours it should be removed by hand.

Cows that have aborted should not be bred until they have ceased discharging, and it is important to keep them from the rest of the herd until they have dropped a fullgrown calf.

A prolific means of spreading the infection of this disease is the bull. A bull that has served infected cows will infect other cows he serves unless his penis and sheath have been thoroughly disinfected. One to two quarts of 2 per cent coal tar disinfectant worked up into the sheath will answer the purpose satisfactorily.

\section{GARGE'T.}

Causes. Injuries of the udder, overfeeding, exposure to severe cold, overcrowding of the udder by skipping a milking, and germ infection.

Symptoms. Watery, stringy milk, frequently containing blood; swelling and hardening of one, two, or all quarters of the udder, which has a more or less reddish, inflamed appearance; and the formation of pus in the more advanced stages.

Treatment. Give $\mathrm{I} / 4$ pounds of Epsom salts and I ounce of ginger, dissolved in a quart of tepid water. Support the udder by means of a wide bandage tied at the top line of the animal, and pack a layer of bran between the bandlage and the diseased portion of the udder. Heat the bran by pouring hot water over it. The hot water 
treatment should be repeated at short intervals and should be followed by thorough rubbing of the udder with lard or raw linseed oil, a treatment which may be continued to advantage for 20 minutes. The rubbing materially relieves the swelling and stimulates the secretion of milk. It is important also to milk the diseased quarier or quarters clean at short intervals. The air treatment for milk fever has also been recommended for garget.

\section{NON-INFECTIOUS "CALF SCOURS."}

Causes. Feeding cold, dirty, old, or too much, milk; drinking cold or impure water; irregularities in feeding; feeding from unscalded buckets; and confinement in dark, cold, or filthy stalls.

Treatment. Reduce the amount of milk; feed the milk fresh and at body temperature; feed not less than three times a day, and use only clean, sterilized milk buckets. Give only pure water at body temperature, and add formalin to the milk in the proportion of one part formalin to 4,000 parts of milk until the diarrhea or "scours" is checked. 'The scouring is usually due to the action of fermentative or putrefactive bacteria which are killed or checked by the action of the formalin.

\section{INFECTIOUS "CALF SCOURS."}

This disease is commonly known as white scours and is caused by bacteria. It affects calves usually from a few hours to a few days old, and is very fatal. The discharges are usually of a rather light color and have an offensive odor. Medicine is of little avail. The disease must therefore be combatted by methods of prevention. Washing the vagina of the cow with disinfectant solution shortly before calving, disinfecting the navel of the 
new-born calf at short intervals for a few days, and placing the calf in a disinfected stall, are good measures of prevention.

\section{INDIGESTION .}

Causes. Overfeeding; feeding too much coarse, indigestible feed ; sudden changes of feed; stale, moldy, frosted or decomposing feeds; irregularities of feeding; and lack of exercise.

Symptoms. Loss of appetite, suspended rumination, dull, sickly appearance, and usually constipation.

Treatment. Feed light ration containing laxative and green feeds, such as linseed meal, pasture, roots, silage, etc. Supply plenty of water and give $\mathrm{I}$ to $\mathrm{I} / 2$ pounds of Epsom salts and I ounce ginger, or $I$ to 2 pints of raw linseed oil, according to the degree of constipation.

\section{RETENTION OF AFTERBIRTH.}

If the afterbirth does not come away within 48 hours it should be removed by hand. Carefully disinfect the hand and arm, grease the same and insert into the womb, where the afterbirth must be carefully loosened from the button-like projections to which it is attached. As soon as removed, flush out the vagina and womb with warm disinfectant solution.

When cows are provided with laxative feed and warm water shortly before and after calving, the afterbirth will almost always drop away in due time. If the bowels are not perfectly loose at calving time, administer a purgative.

The retention of the afterbirth for a longer period than 48 hours - vill cause it gradually to decompose and slough off, causing a foul discharge from the vagina and seri- 
ously impairing the health of the animal. Blood poisoning may also result from the prolonged retention of the afterbirth.

INVERSION OF THE WOMB.

Severe straining after calving may cause the further portion of the womb to protrude through the opening leading into it, thus causing an inversion of the organ. In this inverted condition a portion or all of it may pass out of the vagina. As soon as this is noticed, wash and disinfect the protruded portion and push it back into its normal position. This done, apply a truss or pessary to hold the womb in position until the straining or expulsive movements cease.

\section{TUBERCULOSIS.}

Cause. This disease is caused by a specific organism known as the tubercle bacillus. The germs are commonly inhaled, though they may also be taken into the body through the food. Unsanitary stabling, lack of nourishment, and inherent constitutional weakness, are greatly responsible for the prevalence of this disease.

Symptoms. A short cough, enlargement of the lymph glands at the throat, emaciation, and a general unthrifty appearance. In its early stages it is difficult, however, to detect the disease except by the tuberculin test.

The Tuberculin Test. The usefulness of this test as a diagnostic agent rests upon the fact that when a substance called "tuberculin" is injected under the skin of an animal, the injection is followed by a rise of temperature in infected animals, while in those unaffected the temperature remains the same. It must be added, however, that in the last stages of the disease, tuberculin fails 
as a diagnostic agent, but this is of little consequence since the disease is readily recognized in these stages by a physical examination.

Method of Making the Tuberculin Test. In making: this test the following particulars must be observed:

I. Secure the necessary tuberculin from the government.

2. Secure a clinical thermometer, a sharp, hollow needle, and a graduated, hypodermic syringe from dealers in veterinary instruments.

3. Make the test during the cooler season of the year.

4. Do not test cows shortly before or after calving.

5. Do not test cows that are in heat, or suffering from garget or other diseases.

6. Do not allow cows to drink very cold water.

7. Keep the animals in a normal condition as to feed, confinement, etc., during the test.

8. Do not test animals which show a temperature as high as $103^{\circ} \mathrm{F}$.

Proceed with the test as follows: First ascertain the normal temperature of the cows by holding a clinical thermometer in the rectum for about five minutes. Three observations are necessary: One at 6 a. m., another at noon, and the last at 6 p. m. At Io p. m., the same day, inject under the skin at the neck or shoulder, 2 cubic centimeters of tuberculin for animals of about I,OoO pounds live weight and proportionally more for heavier cows. At 6 o'clock the next morning take the temperature again as before, but at intervals of two hours until five or six readings have been taken. If the maximum temperature after the injection is two or more degrees higher than it was before the injection of the tuberculin, the animal is considered tuberculous. If the rise of tem- 
perature is one and a half degrees, the case may be considered suspicious.

The needle and place of injection should be disinfected, and care should be exercised not to excite the cows during any period of the test. Do not retest for tuberculosis within 60 days. As a rule every cow in the herd should be tested once a year for tuberculosis.

\section{BARRENNESS.}

Causes. Lack of exercise, improper feeding, in-andin breeding, closing of the mouth of the womb, and an acid condition of the vagina.

Treatment. If overfat reduce the amount of feed and give plenty of exercise. If the mouth of the womb is closed, open by inserting the forefinger or by applying solid extract of Belladonna to the part. An acid condition of the vagina may be overcome by thorough syringing with 2 per cent solution of bicarbonate of soda a few hours previous to service. A treatment much recommended lately is known as the yeast treatment and is used as follows : Dissolve an ordinary compressed yeast cake in a cup of warm water and allow to ferment. Add this to a quart of warm water and use to wash out the vagina some hours before service. The vagina should be washed out with soapy water just previous to the injection of the yeast solution.

\section{BLOAT OR HOVEN.}

Causes. Overeating, suddenly turning cows on rich, green feed, like clover pasture, and fermentation of the feed. There is as a rule a great deal of gas produced, causing a great distention of the left side.

Treatment. Immediately place a gag in the mouth, 
and in mild cases, give an ounce of spirits of turpentine and one-half pint of raw linseed oil. Keep the animal moving and pour cold water on the loins. When relief comes, administer a purgative.

In severe cases tap the left side (paunch) with a slender knife or a trocar. Tap at a point equidistant from the point of the hip, the last rib, and the spinal column.

\section{TEA'T TROUBLES.}

Hard Milkers. Hard milking is caused by too small an opening in the teat. Enlarge the opening by using a teat bistoury when the cow is in full flow of milk.

Sore or Chapped Teats. Due to exposure to cold, wet weather and rough handling. Treat with lard or vaseline.

Warts. May be removed by applying lunar caustic.

Closed or Obstructed Teats. Caused by injury or clotted milk. Keep open by inserting a milk tube.

Leaky Teats. Prevent unusual distention by milking three or four times daily. If this is not sufficient, a fairly tight fitting bandage, like the finger of a glove, may be placed around the teat.

\section{STRINGY OR ROPEY MILK.}

This is due to certain species of bacteria which find their way into the udder through the teats. These bacteria are associated with filth and the trouble must be overcome by keeping cows away from filthy places. This trouble should not be confused with garget.

\section{BLOODY MILK.}

This is usually due to an injury to the udder. Bathe the udder with hot water and apply lard. 
SELF-SUCKING COWS.

Prevent by putting a halter on the cow with a strong, stiff piece of leather running over the nose. Fill this strip of leather with sharp nails.

\section{LICE.}

Two per cent coal tar disinfectants are usually used for killing lice. The Oklahoma station recommends a "kerosene emulsion," which is made by using $1 / 2$ pound hard soap, 2 gallons of a cheap grade of kerosene and I gallon of water. Cut up the soap and dissolve in hot water; then add the kerosene and thoroughly mix. Before applying to the animals dilute this mixture with 7 gallons of water. Apply by means of a sponge, brush, or spray pump.

\section{WARBLES OR GRUBS.}

These are found just below the skin in the backs of cattle and constitute the larval form of the ox bot-fly or heel-fly. As they develop they cause swellings in the back and are thus easily recognized. Wherever there is a swelling there is also an opening in the skin through which the grubs may be easily squeezed and killed. They may also be destroyed by the application of kerosene. 



\title{
PART II.
}

\section{MILK AND ITS PRODUCTS.}

\author{
CHAPTER XVII.
}

MILK.

Milk, in a broad sense, may be defined as the normal secretion of the mammary glands of animals that suckle their young. It is the only food found in Nature containing all the elements necessary to sustain life. Moreover it contains these elements in the proper proportions and in easily digestible and assimilable form.

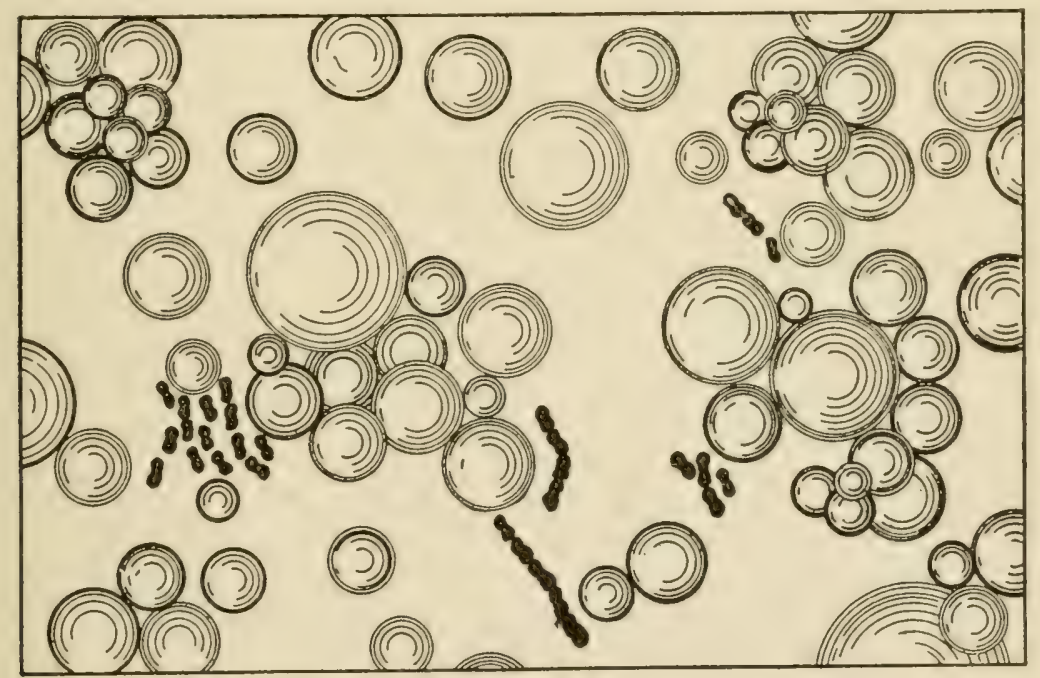

Microscopic appearance of milk showing relative size of fat globules and bacteria.-Russell's Dairy Bacteriology.

Physical Properties. Milk is a whitish opaque fluid possessing a sweetish taste and a faint odor suggestive of cows' breath. It has an amphioteric reaction, that is, 
it is both acid and alkaline. This double reaction is due largely to acid and alkaline salts and possibly to small quantities of organic acids.

Milk has an average normal specific gravity of I.032, with extremes rarely exceeding I.029 and I.033. After standing a few moments it loses its homogenous character. Evidence of this we have in the "rising of the cream." This is due to the fact that milk is not a perfect solution but an cmulsion. All of the fat, the larger portion of the casein, and part of the ash are in suspension.

In consistency milk is slightly more viscous than water, the viscosity increasing with the decrease in temperature. It is also exceedingly sensitive to odors, possessing great absorption properties. This teaches the necessity of placing milk in clean pure surroundings.

Chemical Composition. The composition of milk is very complex and variable, as will be seen from the following figures:

Average Composition of Normal Milk. A compilation of figures from various. American $\mathrm{E}_{\mathrm{x}}$ periment Stations.

Water ......................... 87.1\%

Eutter fat .................... 3.9\%

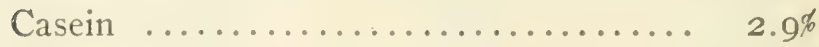

Albumen ......................... $\quad .5 \%^{\%}$

Sugar ...................... 4.9.

Ash ........................... .7\%

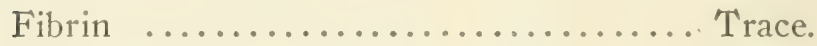

Galactase ...................... Trace.

I00.0\%

The great variations in the composition of milk are shown by the figures from Koenig, given below: 
Maximum. Minimum.

\begin{tabular}{|c|c|c|}
\hline Water & 90.69 & 80.32 \\
\hline Fat .. & 6.47 & 1.67 \\
\hline Casein & 4.23 & I. 79 \\
\hline Albumen ............ & I. 44 & .25 \\
\hline 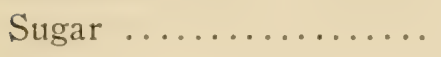 & 6.03 & 2. II \\
\hline Ash $\ldots \ldots \ldots \ldots \ldots \ldots$ & I. $2 \mathrm{I}$ & .35 \\
\hline
\end{tabular}

These figures represent quite accurately the maximum and minimum composition of milk except that the maximum for fat is too low. The author has known cows to yield milk testing $7.6 \%$ fat, and records show tests even higher than this.

\section{BUT'TER FAT.}

This is the most valuable as well as the most variable constituent of milk. It constitutes about $83 \%$ of butter and is an indispensable constituent of the many kinds of whole milk cheese now found upon the market. It also measures the commercial value of milk and cream, and is used as an index of the value of milk for butter and cheese production.

Physical Properties. Butter fat is suspended in milk in the form of extremely small globules numbering about IOO,000,000 per drop of milk. These globules vary considerably in size in any given sample, some being five times as large as others. The size of the globules is affected mostly by the period of lactation. As a rule the size decreases and the number increases with the advance of the period. In strippers' milk the globules are sometimes so small as to render an efficient separation of the cream and the churning of same impossible.

The size of the fat globules also varies with different breeds. In the Jersey breed the diameter of the globule 
is one eight-thousandth of an inch, in the Holstein one twelve-thousandth, while the average for all breeds is about one ten-thousandth.

Night's milk usually has smaller globules than morning's. The size of the globules also decreases with the age of the cow.

The density or specific gravity of butter fat at $100^{\circ} \mathrm{F}$. is .9I and is quite constant. Its melting point varies between wide limits, the average being $92^{\circ} \mathrm{F}$.

Composition of Butter Fat. According to Richmond, butter fat has the following composition:
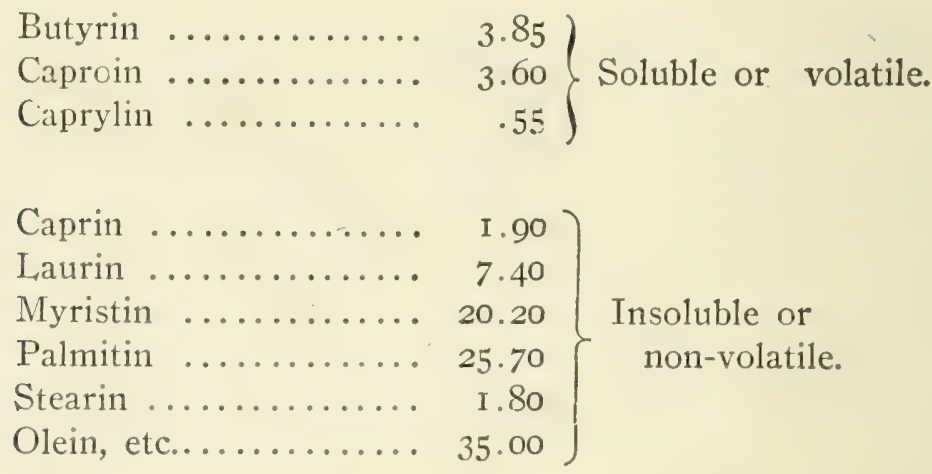

This shows butter fat to be composed of no less than nine distinct fats, which are formed by the union of glycerine with the corresponding fatty acids. Thus, butyrin is a compound of glycerine and butyric acid; palmitin, a compound of glycerine and palmitic acid, etc. The most important of these acids are palmitic, oleic, and butyric.

Palmitic acid is insoluble, melts at $144^{\circ} \mathrm{F}$., and forms (with stearic acid) the basis of hard fats.

Oleic acid is insoluble, melts at $57^{\circ} \mathrm{F}$., and forms the basis of soft fats. 
Butyric acid is soluble and is a liquid which solidifies at $-2^{\circ} \mathrm{F}$. and melts again at $28^{\circ} \mathrm{F}$.

Insoluble Fats. A study of these fats is essential in elucidating the variability of the churning temperature of cream. As a rule this is largely determined by the relative amounts of hard and soft fats present in butter fat. Other conditions the same, the harder the fat the higher the churning temperature. Scarcely any two milks contain exactly the same relative amounts of hard and soft fats, and it is for this reason that the churning temperature is such a variable one.

The relative amounts of hard and soft fats are influenced by:

I. Breeds.

2. Feeds.

3. Period of lactation.

4. Individuality of cows.

The butter fat of Jerseys is harder than that of Holsteins and, therefore, requires a relatively high churning temperature, the difference being about six degrees.

Feeds have an important influence upon the character of the butter fat. Cotton seed meal and bran, for example, materially increase the percentage of hard fats. Gluten feeds and linseed meal, on the other hand, produce a soft butter fat.

With the advance of the period of lactation the percentage of hard fat increases. This chemical change, together with the physical change which butter fat undergoes, makes churning difficult in the late period of lactation.

The individuality of the cow also to a great extent influences the character of the butter fat. It is inherent 
in some cows to produce a soft butter fat, in others to produce a hard butter fat, even in cows of the same breed.

Soluble Fats. 'The soluble or volatile fats, of which butyrin is the most important, give milk and sweet cream butter their characteristic flavors. Butyrin is found only in butter fat and distinguishes this from all vegetable and other animal fats.

The percentage of soluble fats decreases with the period of lactation, also with the feeding of dry feeds and those rich in protein. Succulent feeds and those rich in carbohydrates, according to experiments made in Holland and elsewhere, increase the percentage of soluble fats. This may partly account for the superiority of the flavor of June butter.

It may be proper, also, to discuss under volatile or soluble fats those abnormal flavors that are imparted to milk, cream, and butter by weeds like garlic and wild onions, and by various feeds such as beet tops, rape, partially spoiled silage, etc. These flavors are undoubtedly due to abnormal volatile fats.

Cows should never be fed strong flavored feeds shortly before milking. When this is done the odors are sure to be transmitted to the milk and the products therefrom. When, however, feeds of this kind are fed shortly after milking no bad effects will be noticed at the next milking.

Albumenoids. These are nitrogenous compounds which give milk its high dietetic value. Casein, albumen, globulin, and nuclein form the albumenoids of milk, the casein and albumen being by far the most important.

Casein. This is a white colloidal substance, possessing neither taste nor smell. It is the most important tissueforming constituent of milk and forms the basis of an almost endless variety of cheese. 
The larger portion of the casein is suspended in milk in an extremely finely divided amorphus condition. It is intimately associated with the insoluble calcium phosphate of milk and possibly held in chemical combination with this. Its study presents many difficulties, which leaves its exact composition still undetermined.

Casein is easily precipitated by means of rennet extract and dilute acids; but the resulting precipitates are not identically the same. It is not coagulated by heat.

Albumen. In composition albumen very closely resembles casein, differing from this only in not containing sulphur. It is soluble and unaffected by rennet, which causes most of it to pass into the whey in the manufacture of cheese. It is coagulated at a temperature of $170^{\circ} \mathrm{F}$. It is in their behavior toward heat and rennet that casein and albumen radically differ.

Milk Sugar. This sugar, commonly called lactose, has the same chemical composition as cane sugar, differing from it chiefly in possessing only a faint sweetish taste. It readily changes into lactic acid when acted upon by the lactic acid bacteria. This causes the ordinary phenomenon of milk souring. The maximum amount of acid in milk rarely exceeds .9\%, the germs usually being checked or killed before this amount is formed. There is therefore always a large portion of the sugar left in sour milk. All of the milk sugar is in solution.

Ash. Most of the ash of milk exists in solution. It is composed of lime, magnesia, potash, soda, phosphoric acid, chlorine, and iron, the soluble lime being the most important constituent. It is upon this that the action of rennet extract is dependent. For when milk is heated to high temperatures the soluble lime is rendered insoluble and rennet will no longer curdle milk. It seems also that 
the viscosity of milk and cream is largely due to soluble lime salts. Cream heated to high temperatures loses its viscosity to such an extent that it can not be made to "whip." Treatment with soluble lime restores its original viscosity. The ash is the least variable constituent of milk.

Colostrum Milk. This is the first milk drawn after parturition. It is characterized by its peculiar odor, yellow color, broken down cells, and high content of albumen which gives it its viscous, slimy appearance and causes it to coagulate on application of heat.

According to Eugling the average composition of colostrum milk is as follows:

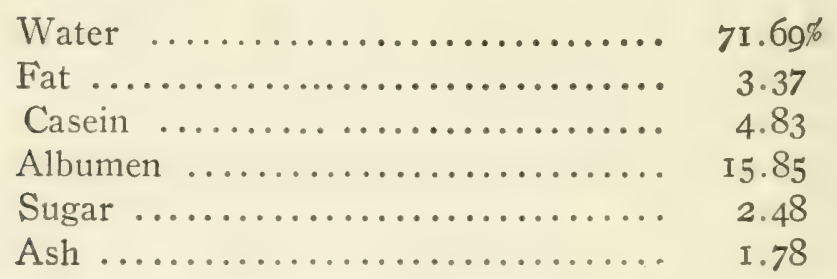

The secretion of colostrum milk is of very short duration. Usually within four or five days after calving it assumes all the properties of normal milk. In some cases, however, it does not become normal till the sixth or even the tenth day, depending largely upon the condition of the animal.

A good criterion in the detection of colostrum milk is its peculiar color, odor, and slimy appearance. The disappearance of these characteristics determines its fitness for butter production.

Milk Secretion. Just how all of the different constituents of milk are secreted is not yet definitely understood. But it is known that the secretion takes 
place in the udder of the cow, and principally during the process of milking. Further, the entire process of milk elaboration seems to be under the control of the nervous system of the cow. This accounts for the changes in flow and richness of milk whenever cows are subjected to abnormal treatment. It is well known that a change of milkers, the use of rough language, or the abuse of cows with dogs and milk stools, seriously affects the production of milk and butter fat. It is therefore of the greatest practical importance to milk producers to treat cows as gently as possible, especially during the process of milking.

How Secreted. The source from which the milk constituents are elaborated is the blood. It must not be supposed, however, that all the different constituents already exist in the blood in the form in which we find them in milk, for the blood is practically free from fat, casein, and milk sugar. These substances must then be formed in the cells of the udder from material supplied them by the blood. Thus there are in the udder cells that have the power of secreting fat in a manner similar to that by which the gastric juice is secreted in the stomach. Similarly, the formation of lactose is the result of the action of another set of cells whose function is to produce lactose. It is believed that the casein is formed from the albumen through the activity of certain other cells. The water, albumen, and soluble ash probably pass directly from the blood into the milk ducts by the process known as osmosis.

Variations in the Quality of Milk. Milk from different sources may vary considerably in composition, particularly in the percentage of butter fat. Even the 
milk from the same cow may vary a great deal in composition. The causes of these variations may be assigned to two sets of conditions: I.-Those natural to the cow. II.-Those of an artificial nature.

I. QUALITY OF MILIK AS AFFECTED BY NATURAL, CONDITIONS.

I. The composition of the milk of all cows undergoes a change with the advance of the period of lactation. During the first five months the composition remains practically the same. After this, however, the milk becomes gradually richer until the cow "dries up." The following figures from Van Slyke illustrate this change:

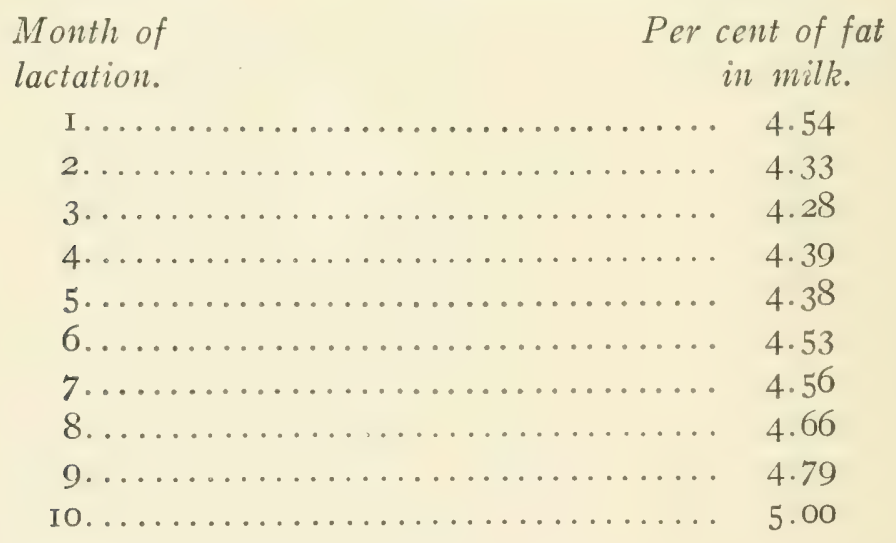

It will be noticed from these figures that the milk actually decreases somewhat in richness during the first three months of the period. But just before the cow dries up, it may test as high as $8 \%$.

2. The quality of milk also differs with different breeds. Yet breed differences are less marked than those of the individual cows of any particular breed.

Some breeds produce rich milk, others relatively poor 
milk. The following data obtained at the New Jersey Experiment Station illustrates these differences:

\begin{tabular}{|c|c|c|c|c|c|}
\hline Breed. & $\begin{array}{l}\text { Total } \\
\text { Solids. }\end{array}$ & Fat. & $\begin{array}{l}\text { Milk } \\
\text { Sugar. }\end{array}$ & Proteids. & Ash. \\
\hline & Per cent. & Per cent. & Per cent. & Per cent. & Per cent. \\
\hline Ayshire... & 12.70 & 3.68 & 4.84 & 3.48 & .69 \\
\hline Guernsey . & 14.48 & 5.02 & 4.80 & 3.92 & .75 \\
\hline Holstein. & 12.12 & 3.51 & 4.69 & 3.28 & .64 \\
\hline Jersey.... & 14.34 & 4.78 & 4.85 & 3.96 & .75 \\
\hline
\end{tabular}

3. Extremes in the composition of milk are usually to be ascribed to the individuality or "make up" of the cow. It is inherent in some cows to produce rich milk, in others to produce poor milk. In other words, Nature has made every cow to produce milk of a given richness, which can not be perceptibly changed except by careful selection and breeding for a number of generations.

II. QUALITY OF MILT AS AFFECTED BY ARTIFICIAL, CONDITIONS.

I. When cows are only partially milked they yield poorer milk than when milked clean. This is largely explained by the fact that the first drawn milk is always poorer in fat than that drawn last. Fore milk may test as low as $.8 \%$, while the strippings sometimes test as high as $14 \%$.

2. Fast milking increases both the quality and the quantity of the milk. It is for this reason that fast milkers are so much preferred to slow ones. 
3. The richness of milk is also influenced by the length of time that elapses between the milkings. In general, the shorter the time between the milkings the richer the milk. This, no doubt, in a large measure accounts for the differences we often find in the richness of morning's and night's milk. Sometimes the morning's milk is the richer, at other times the evening's, depending largely upon the time of day the cows are milked. Milk can not, however, be permanently enriched by milking three times in stead of twice a day.

4. Lnusual excitement of any hind reduces the qualify of milk. The person who abuses cows by dogs, milk stools, or boisterousness, pays dearly for it in a reduction 0 : both the quality and the quantity of milk produced.

5. Starvation also seriously affects both the quality and the quantity of milk. It has been repeatedly shown, in this country and in Europe, that under-feeding to any great extent results in the production of milk poor in fat.

6. Sudden changes of feed may slightly affect the richness of milk, but only temporarily.

So long as cows are fed a full ration, it is not possible to change the richness of milk permanently, no matter what the character of feed composing the ration.

7. Irregularities of feeding and milhing, exposure to heat, cold, rain, and flies, tend to reduce both the quantity and the quality of milk produced. 


\section{CHAPTER XVIII.}

\section{THE BABCOCK TEST.}

This is a cheap and simple device for determining the percentage of fat in milk, cream, skim-milk, buttermilk, whey, and cheese. It was invented in I89o by Dr. S. M. Babcock, of the Wisconsin Agricultural Experiment Station, and ranks among the leading agricultural inventions of modern times. The chief uses of the Babcock test may be mentioned as follows:

I. It has made possible the payment for milk according to its quality.

2. It has enabled butter and cheese makers to detect undue losses in the process of manufacture.

3. It has made possible the grading up of dairy herds by locating the poor cows.

4. It has, in a large measure, done away with the practice of watering and skimming milk.

Principle of the Babcock Test. The separation of the butter fat from milk with the Babcock test is made possible:

I. By the difference between the specific gravity of butter fat and milk serum.

2. By the centrifugal force generated in the tester.

3. By burning the solids not fat with a strong acid.

Sample for a Test. Whatever the sample to be tested, always eighteen grams are used for a test. In testing cream and cheese, the sample is weighed. For testing milk, skim-milk, buttermilk, and whey, weighing requires 
too much time. Indeed, with these substances weighing is not necessary as sufficiently accurate samples are ob-
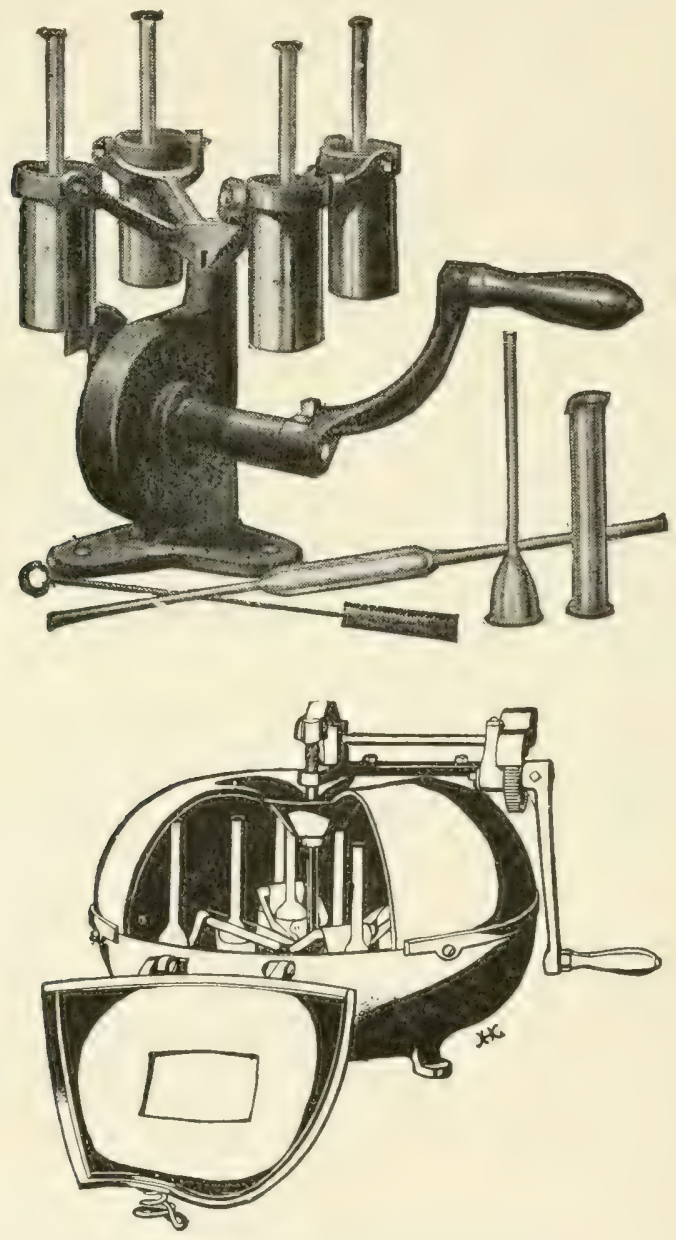

Fig. 29-Two styles of Babcock testers.

tained by measuring which is the method universally employed. In making a Babcock test it is of the greatest importance to secure a uniform sample of the substance to be tested. 
Apparatus. This consists essentially of the following parts: A, Babcock tester; B, milk bottle; C, cream bottle; $\mathrm{D}$, skim-milk bottle; $\mathrm{E}$, pipette or milk measure; $\mathrm{F}$, acic measures; $G$, cream scales; $H$, mixing cans; $I$, dividers.

A. Babcock Tester. This machine, shown in Fig. 29, consists of a revolving wheel placed in a horizontal position and provided with swinging pockets for the bottles. This wheel is rotated by means of a worm wheel (lower machine) at the top of the tester. When the tester stops the pockets hang down allowing the bottles to stand up. As the wheel begins rotating the pockets move out causing the bottles to assume a horizontal position. The wheel is enclosed in a cast iron frame provided with a cover.

B. Milk Bottle. This has a neck graduated to ten large divisions, each of which reads one per cent. Each large division is subdivided into five smaller ones, making each sublivision read .2\%. The contents of the neck from the zero mark to the 10\% mark is equivalent to two cubic centimeters. Since the Babcock test does not give the percentage of fat by volume but by weight, the I0\% scale on the neck of the bottle will, therefore, hold I.8 grams of fat. In other words, if the scale were filled with water it would hold two grams; but fat being only .9 as heavy, 2 cubic centimeters of it would weigh ninetenths of two grams or I.8 grams. This is exactly I0\% of I8 grams, the weight of the sample used for testing. A milk bottle is shown in Fig. 30.

C. Cream Bottles. These are graduated from $30 \%$ to $55 \%$. A $30 \%$ bottle is shown in Fig. 3I. Since cream usually tests more than $30 \%$, the sample must be divided wher. the $30 \%$ bottles are used. 


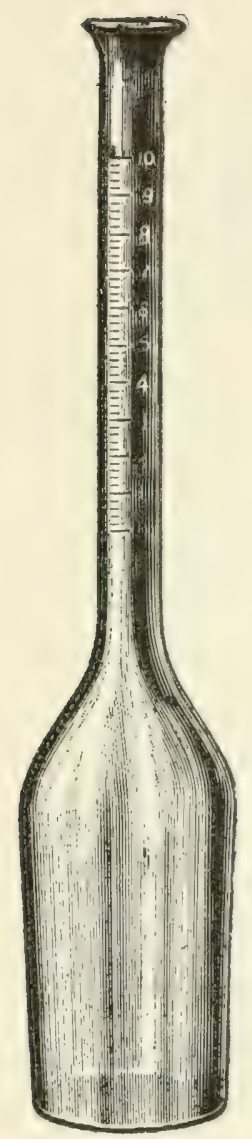

Fig.30.-Mills bottle.

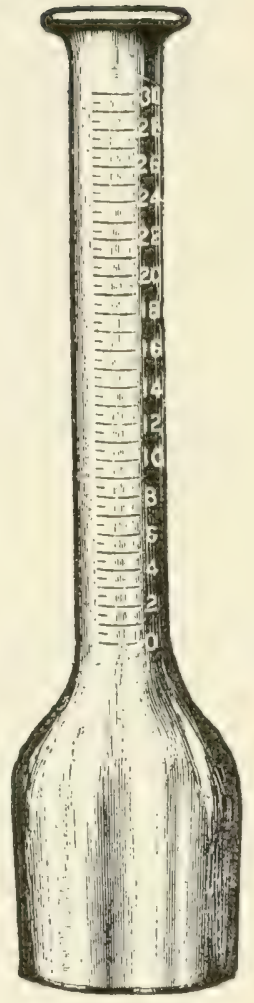

Fig. 31.-Cream bottle.

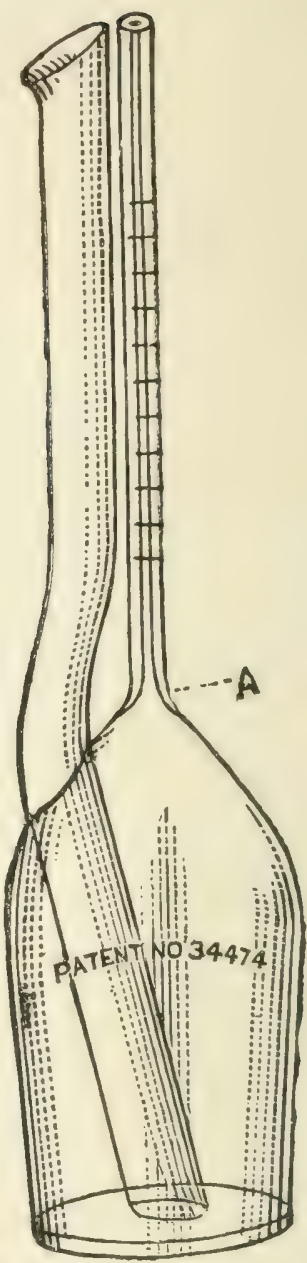

Fig. 32.-Skim-milk bottle.

D. Skim=milk Bottle. This bottle, shown in Fig. 32, is provided with a double neck, a large one to admit the milk, and a smaller graduated neck for fat reading. The entire scale reads one-half per cent. Being divided into ten subdivisions eacin subdivision reads .05\%. The same bottle is also used for testing buttermilk. 

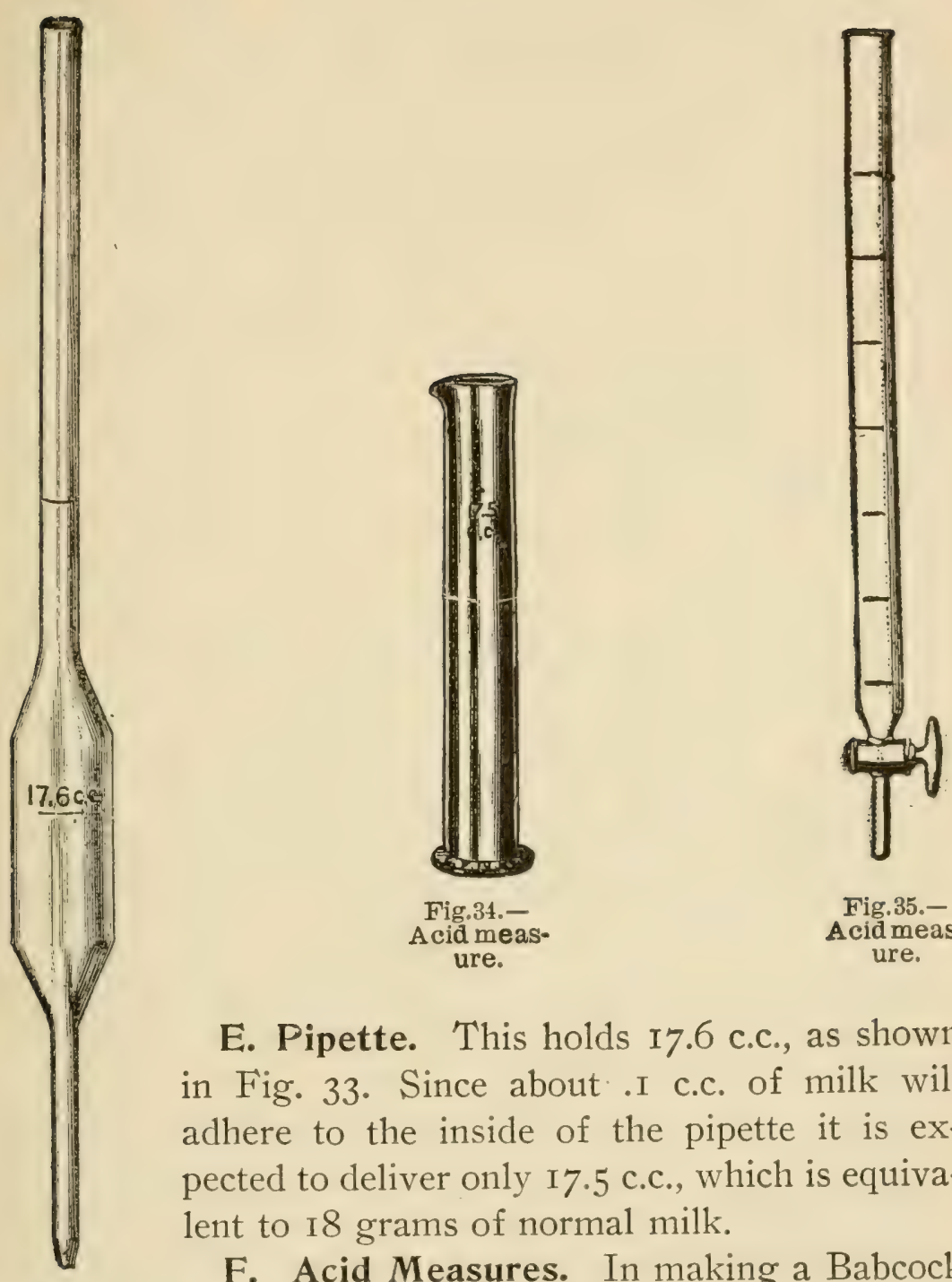

Fig. 35.Acidme
ure.

E. Pipette. This holds I7.6 c.c., as shown in Fig. 33. Since about. .I c.c. of milk will adhere to the inside of the pipette it is expected to deliver only I 7.5 c.c., which is equivalent to 18 grams of normal milk.

F. Acid Measures. In making a Babcock Fig.33.-Pi- test equal quantities, by volume, of acid and
pette. milk are used. The acid measure, shown in Fig. 34, holds I7.5 c.c. of acid, the amount needed for one test. The one shown in Fig. 35 is divided into six divisions, each of which holds 17.5 c.c. or one charge of acid. Where 
many tests are made a graduate of this kind saves time in filling, but should be marle to hold twenty-five charges.

H. A cream scales commonly used is illustrated in Fig. 36.

Acid. The acid used in the test is commercial sul-

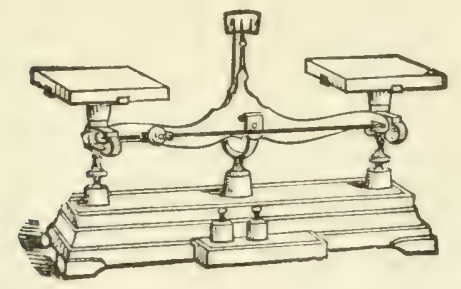

Fig.38.-Cream scales.

phuric acid having a specific gravity of $\mathrm{I} .82$ to 1.83 . When the specific gravity of the acid falls below $\mathrm{I} .82$ the milk solids are not properly burned and particles of curd may appear in the fat. On the other hand, an acid with a specific gravity above 1.83 has a tendency to blacken or char the fat.

The sulphuric acid, besides burning the solids not fat, facilitates the separation of the fat by raising the specific gravity of the medium in which it floats.

Sulphuric acid must be kept in glass bottles provided with glass stoppers. Exposure to the air materially weakens it.

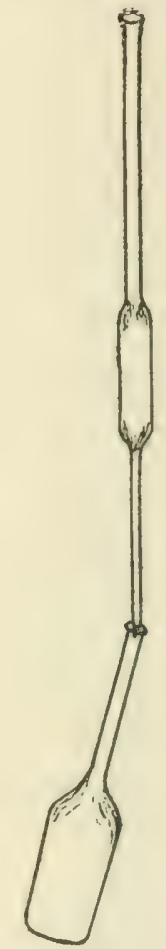

Fig.3\%.-Showing manner of emptying pipette.

Making a Babcock Test. The different steps are indicated as follows:

I. Thoroughly mix the sample.

2. Immediately after mixing insert the pipette into the milk and suck until the milk has gone above the mark on the pipette, then quickly place the fore finger over the 
top and allow the milk to run down to the mark by slowly relieving the pressure of the finger.

3. Empty the milk into the bottle in the manner shown in Fig. 37.

4. Add the acid in the same manner in which the milk was emptied into the bottle.

5. Mix the acid with the milk by giving the bottle a slow rotary motion.

6. Allow mixture to stand a few minutes.

7. Shake or mix again and then place the bottle in the tester.

8. Run tester four minutes at the proper speed.

9. Add moderately hot water until contents come to the neck of the bottle.

IO. Whirl one minute.

II. Add moderately hot water until contents of the bottle reach about the $8 \%$ mark.

I2. Whirl one minute.

I3. Read test.

How to Read the Test. At the top of the fat column is usually quite a pronounced meniscus as shown in Fig. 38. A less pronounced one is found at the bottom of the column. The fat should be read from the extremes of the fat column, I to 3 , not from 2 to 4 , when its temperature is about $140^{\circ} \mathrm{F}$. Too high a temperature gives too high

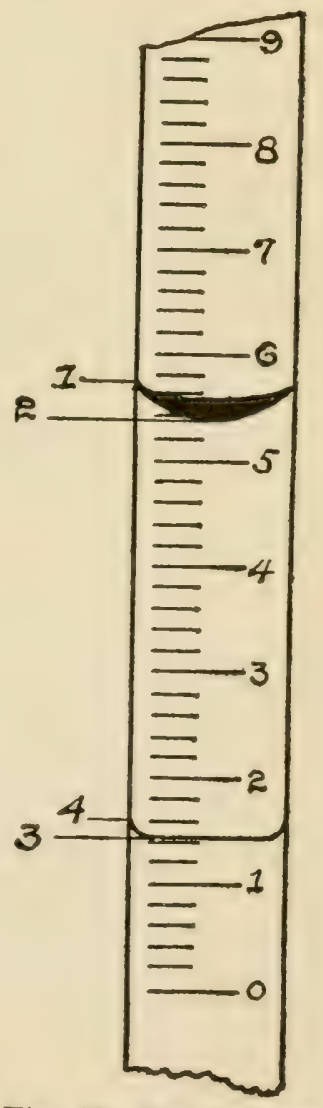

Fig. 38.-Fat column showing meniscuses. 
a reading, because of the expanded condition of the fat, while too low a temperature gives an uncertain reading.

Precautions in Making a Test. I. Be sure you have a fair sample.

2. The temperature of the milk should be about 60 or 70 degrees.

3. Always mix twice after acid has-been added.

4. Be sure your tester runs at the right speed.

5. Use nothing but clean, soft water in filling the bottles.

6. Be sure the tester does not jar.

7. Be sure the acid is of the right strength.

8. Mix as soon as acid is added to milk.

9. Do not allow the bottles to become cold before reading the test.

IO. Read the test twice to insure a correct reading.

The water added to the test bottles after they have been whirled should be clean and pure. Water containing much lime seriously affects the test. Such water may be used, however, when first treated with a few drops of sulphuric acid.

As stated before, skim-milk, buttermilk, and cream are tested in the same way as milk, with the exception that the cream sample is weighed, not measured.

Testing Cream. Accurate tests of cream cannot be secured by measuring the sample into the bottle as is done in the case of milk. The reason for this is that the weight of cream varies with its richness. The richer the cream the less it weighs per unit volume. This is illustrated in the following table by Farrington and Woll: 
Weight of fresh separator cream delivered by a I7.6 c. c. pipette.

Per cent. of fat
in cream.
I0
I5
20
25
30
35
40
45
50

\begin{tabular}{|c|}
\hline $\begin{array}{c}\text { Specific gravity } \\
\text { (weighed). }\end{array}$ \\
\hline 1.023 \\
\hline I.OI 2 \\
\hline I.008 \\
\hline 1.002 \\
\hline .996 \\
\hline .980 \\
\hline .966 \\
\hline .950 \\
\hline .947 \\
\hline
\end{tabular}

Weight of cream
in grams.
I7.9
I 7.7
I7.3
I7.2
I7.0
I6.4
I6.3
I6.2
I 5.8

With cream testing below 30\% the full i8 grams may be added to one bottle and tested in the usual way. Where the cream tests above $30 \%$ better results are obtained by using only half the full sample of cream (9 grams) and adding to this 9 grams of water. To this mixture the full amount of acid is added. Obviously in this case the test must be multiplied by 2 to get the correct reading.

General Pointers: Black fat is caused by

I. Too strong acid.

2. Too much acid.

3. Too high a temperature of the acid or the milk.

4. Not mixing soon enough.

5. Dropping the acid through the milk.

Foam on top of fat is caused by hard water, and can be prevented by adding a few drops of sulphuric acid to the water.

Unclean or cloudy fat is caused by

I. Insufficient mixing.

2. Too low speed of tester.

3. Too low temperature.

4. Too weak acid.

Curd particles in fat are caused by

I. Too weak acid. 
2. Not enough acid.

3. Too low temperature.

Cleaning Test Bottles. As soon as the test is read, the bottles are emptied by shaking them up and down so as to remove the white sediment. Next wash them in hot water containing some alkali, and finally rinse them with hot water. Occasionally the bottles should be rinsed with a special cleaning solution, which is made by dissolving about one ounce of potassium bichromate in one pint of sulphuric acid. A small brush should also occasionally be run up and down the neck of the bottle.

Making and Reading Cream Tests. The different steps in testing cream are essentially the same as in testing milk. However, as already stated, the cream must be weighed and tested in a special bottle. Furthermore, special precautions must be used in reading the test.

It is well known that reading the extremes of the fat column gives too high a reading. This error is due to the meniscus at the top of the fat column, the size of which varies with the width of the neck. Farrington and Woll recommend reading from the lowest extremity of the fat column to the bottom of the upper meniscus. This is the method commonly employed in reading tests. Eckles and Wayman recommend removing the meniscus by adding a small quantity of amyl alcohol (colored red) to the top of the fat column. Farrington suggests adding a few drops of fat-saturated alcohol to the top of the fat as a means of removing the meniscus. Ordinary alcohol has a solvent action on butter fat, hence the necessity of using fat-saturated alcohol.

Hunziker* after a thorough investigation of the sub-

*Bulletin 145, Indiana Experiment Station. 
ject, has found "glymol" best suited for the removal of the meniscus. Glymol is known commercially as white mineral oil and is used for typewriters, sewing machines, etc. It will give satisfactory results without the addlition of coloring matter. It may be colored, however, by placing a small cheese cloth bag containing "aikanet root" in a bottle of glymol for a day or two. One ounce of alkanet root will color one quart of glymol.

A few drops of the glymol are sufficient, and should be carefully added to the top of the fat column before reading the test.

To get accurate readings the bottles should be read while the temperature of the fat is between $135^{\circ}$ and $140^{\circ}$ F. The bottles should be taken from the tester and placed in a water bath having a temperature of $140^{\circ} \mathrm{F}$. and kept there several minutes, or long enough to cool the fat to $140^{\circ} \mathrm{F}$. The water in the vessel should extend to the extreme top of the fat in the bottles, or preferably a little above. Accurate readings cannot be obtained by reading the bottles directly from the tester; the first bottles removed have too high a temperature while those removed last have too low a temperature. Where hand testers are used, the bottles are usually too cold for satisfactory reading and, therefore, must be heated to the proper temperature. 


\section{CHAP'TER XIX.}

\section{BACTERIA AND MILK FERMENTATIONS.}

A thorough knowledge of bacteria and their action forms the basis of success in butter making. Indeed the man who is lacking such knowledge is making butter in the dark; his is chance work. Much attention will therefore be given to the study of these organisms in this work.

\section{BACTERIA.}

The term bacteria is applied to the smallest of living plants, which can be seen only under the highest powers of the miscroscope. Each bacterium is made up of a single cell. These plants are so small that it would require 30,000 of them laid side by side to measure an inch. Their presence is almost universal, being found in the air, water, and soil ; in cold, hot, and temperate climates; and in living and dead as well as inorganic matter.

Bacteria grow with marvelous rapidity. A single bacterium is capable of reproducing itself a million times in twenty-four hours. They reproduce either by a simple division of the mother cell, thus producing two new cells, or by spore formation in which case the contents of the mother cell are formed into a round mass called a spore. These spores have the power of withstanding unfavorable conditions to a remarkable extent, some being able to endure a temperature of $2 \mathrm{I} 2^{\circ} \mathrm{F}$. for several hours.

Most bacteria require for best growth a moist, warm, and nutritious medium such as is furnished by milk, in 
which an exceedingly varied and active life is possible.

In nature and in many of the arts and industries, bacteria are of the greatest utility, if not indispensable. They play a most important part in the disintegration of vegetable and animal matter, resolving compounds into their elemental constituents in which form they can again be built up and used as plant food. In the art of butter and cheese making bacteria are indispensable. The to. bacco, tanning, and a host of other industries cannot flourish without them.

\section{MILK FERMENTATIONS.}

Definition. In defining fermentation processes, Conn says that, "In general, they are progressive chemical changes taking place under the influence of certain organic substances which are present in very small quantity in the fermenting mass."

With few exceptions, milk fermentations are the result of the growth and multiplication of various classes of bacteria. The souring of milk illustrates a typical fermentation, which is caused by the action of lactic acid bacteria upon the milk sugar breaking it up into lactic acid. Here the chemical change is conversion of sugar into lactic acid.

The most common fermentations of milk are the following:

Milk Fermentations

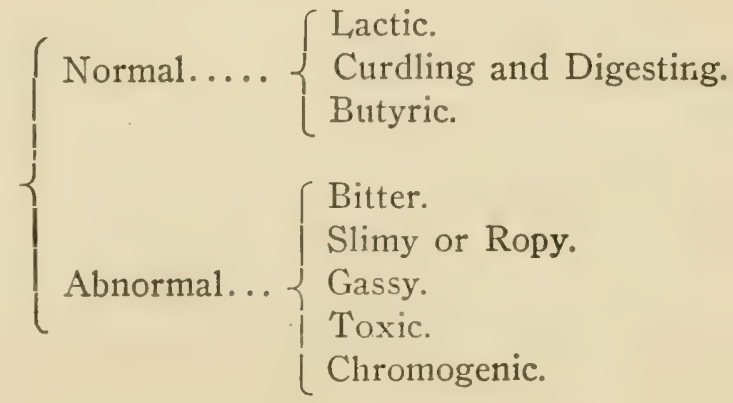


NORMAL FERMEN'TATIONS.

We speak of normal fermentations because milk always contains certain classes of bacteria even when drawn and kept under cleanly conditions. These fermentations will be discussed in the following pages.

\section{LACTIC FERMENTATION.}

This is the most common and by far the most important fermentation of milk. Indeed it is indispensable in the manufacture of butter of the highest quality. The germ causing this fermentation is called Lactici Acidi. It is non-spore bearing and has its optimum growth temperature between $90^{\circ}$ and $98^{\circ} \mathrm{F}$. At $40^{\circ}$ its growth ceases. Exposed to a temperature of $140^{\circ}$ for fifteen minutes it is killed.

The souring of milk and cream, as already mentioned, is due to the action of the lactic acid bacteria upon the milk sugar changing it into lactic acid. Acid is therefore always produced at the expense of milk sugar. But the sugar is never all converted into acid because the production of acid is limited. When the acidity reaches about .9\% the lactic acid bacteria are either checked or killed and the production of acid ceases. Owing to the universal presence of these bacteria it is almost impossible to secure milk free from them.

Under cleanly conditions the lactic acid type of bacteria always predominates in milk. When, however, miik is drawn under uncleanly conditions the lactic organisms may be outnumbered by other species of bacteria which give rise to the numerous taints often met with in milk.

Contradictory as it may seem, the lactic acid bacteria are alike friend and foe to the butter maker. Creamery 
patrons are expected to have milk as free as possible from these germs so that it may arrive at the creamery in a sweet condition. They are therefore expected to thoroughly cool and care for it, not alone to suppress the action of the lactic acid bacteria but also that of the abnormal species that might have gained access to the milk.

While the acid bacteria are objectionable in milk, in cream made into butter they are indispensable. The highly desirable aroma in butter is the result of the growth of these organisms in the process of cream ripening. There are a number of different species of bacteria that have the power of producing lactic acid.

\section{CURDLING AND DIGESTING FERMENTATION.}

In point of numbers this class of bacteria ranks perhaps next to the lactic acid type. Indeed it is very difficult to obtain milk that does not contain them. It is not often, however, that their presence is noticeable owing to their inability to thrive in an acid medium.

According to bacteriologists most of these bacteria secrete two enzymes, one of which has the power of curdling milk, the other of digesting it. The former has the power of rennet, the latter of trypsin. "As a rule," say's Russell, "any organism that possesses the digestive power, first causes a coagulation of the casein in a manner comparable to rennet."

It is only occasionally when the lactic acid organisms are in a great minority, or when for some reason their action has been suppressed, that this class of bacteria manfests itself by curdling milk while sweet. The curd thus formed differs from that produced by lactic acid in being soft and slimy. 
Most of the curdling and digesting bacteria are spore bearing and can thus withstand unfavorable conditions better than the lactic acid bacteria. For this reason milk that has been heated sufficiently to kill the lactic acid bacteria, will often undergo the undesirable changes attributable to the digesting and curdling organisms.

\section{BUTYRIC FERMENTATION.}

It was mentioned that many bacteria have the power of producing lactic acid but that the true lactic acid fermentation is probably caused by a single species. So it is with the butyric acid bacteria. While a number of different organisms are known to produce this acid, Conn is of the opinion that the common butyric fermentation of milk and cream is due to a single species belonging to the anaerobic type.

The butyric acid produced by these organisms is the chief cause of rancid flavors in cream and butter. These bacteria are widely distributed in nature, being particularly abundant in filth. They are almost universally present in milk, from which they are hard to eradicate on account of their resistant spores. It is on account of these spores and their ability to grow in the absence of oxygen that the butyric fermentation is often found in ordinary sterilized milk from which the air has been excluded.

The influence of the butyric acid bacteria is felt mainly in butter and in overripened cream. The latter frequently possesses a rancid odor which must be charged to these bacteria, especially since it is known that overripened cream possesses conditions favorable for their development. Overripening should, therefore, be carefully guarded against. 
The butyric fermentation is rarely noticeable during the early stage of cream ripening and its subsequent development in a highly acid cream is explained by Russell as being "probably due, not so much to the presence of lactic acid, as to the absence of dissolved oxygen, which at this stage has been used up by the lactic acid organisms."

Butter that is apparently good in quality when freshly made, will usually turn rancid when kept at ordinary temperatures a short time. The quickness with which this change comes is dependent largely upon the amount of acid present in cream at the time of churning. Butter made from cream in which the maximum amount of acid consistent with good flavor has been developed, usually possesses poor keeping quality. This seems to indicate that at least part of the rancidity that develops in butter after it is made is due to the butyric acid bacteria, while light and air, doubtless, also contribute much to this end.

\section{ABNORMAL, FERMENTATIONS.}

No trouble needs to be anticipated from these fermentations so long as cleanliness prevails in the dairy. The bacteria that belong to this class are usually associated with filth, and dairies that become infested with them show a lack of cleanliness in the care and handling of the milk. Since milk is frequently infected with one or another of these abnormal fermentations a brief discussion will be given of the most important.

\section{BITTER FERMENTATION.}

Bitter milk and cream are quite common and there are several ways in which this bitterness is imparted: it may 
be due to strippers' milk and to certain classes of feeds and weeds, but most frequently to bacteria. 'This class of bacteria has not yet been studied very thoroughly but we know a great deal about it in a practical way. In milk and cream in which the action of the lactic acid germs has been suppressed by low temperatures, bitterness due to the development of the bitter fermentation is almost certain to be noticeable. When the temperature is such as to cause a rapid development of the lactic fermentation, the bitter fermentation is rarely, if ever, present. It is quite evident from this that the bitter organisms are capable of growing at much lower temperatures than the lactic and that so long as the latter are rapidly growing the bitter fermentation is held in check.

This teaches us that it is not safe to ripen cream below $60^{\circ} \mathrm{F}$. The author has found that cream quickly ripened and then held at a temperature of $45^{\circ}$ for twenty-four hours would show no tendency toward bitterness, while the same cream held sweet at $45^{\circ}$ for twenty-four hours and then ripened would develop a bitter flavor. This indicates that the lactic acid is unfavorable to the development of the bitter fermentation.

The bitter germs produce spores capable of resisting the boiling temperature. This accounts for the bitter taste that often develops in boiled milk.

\section{SLIMY OR ROPY FERMENTATION.}

This is not a common fermentation and rarely causes trouble where cleanliness is practiced in the dairy. The bacteria that produce it are usually found in impure water, dust, and dung. These germs are antagonistic to 
the lactic organisms and for this reason milk infected with them sours with great difficulty.

The action of this class of bacteria is to increase the viscosity of milk, which in mild cases simply assumes a slimy appearance. In extreme cases, however, the milk develops into a ropy consistency, permitting it to be strung out in threads several feet long.

Slimy or ropy milk cannot be creamed and is therefore worthless in the manufacture of butter. Such milk siould not be confused with gargety milk which is stringy when drawn from the cow. The bacteria belonging to this class are easily destroyed as they do not form spores.

\section{GASSY FERMENTATION.}

This is an exceedingly troublesome fermentation in cheese making and is also the cause of much poor flavored butter. The gas germs are very abundant during the warm summer months but are scarcely noticeable in winter. Like the bitter germs, they are antagonistic to the lactic acid bacteria and do not grow during the rapid development of the latter. They are found most abundantly in the barn, particularly in dung.

\section{TOXIC FERMENTATIONS.}

Toxic or poisonous products are occasionally developed in milk as a result of bacterial activity. They are most commonly found in milk that has been kept for some time at low temperature.

\section{CHROMOGENIC FERMENTATTONS.}

Bacteria belonging to this class have the power of imparting to milk various colors. The most common of 
these is blue. It is, however, not often met with in dairy practice since the color usually does not appear until the milk is several days old. The specific organism that causes blue milk has been known for more than half a century and is called cyanogenous. Another color that rarely turns up in dairy practice is produced by a germ known as prodigiosis, causing milk to turn red. Other colors are produced such as yellow, green, and black, but these are of very rare occurrence.

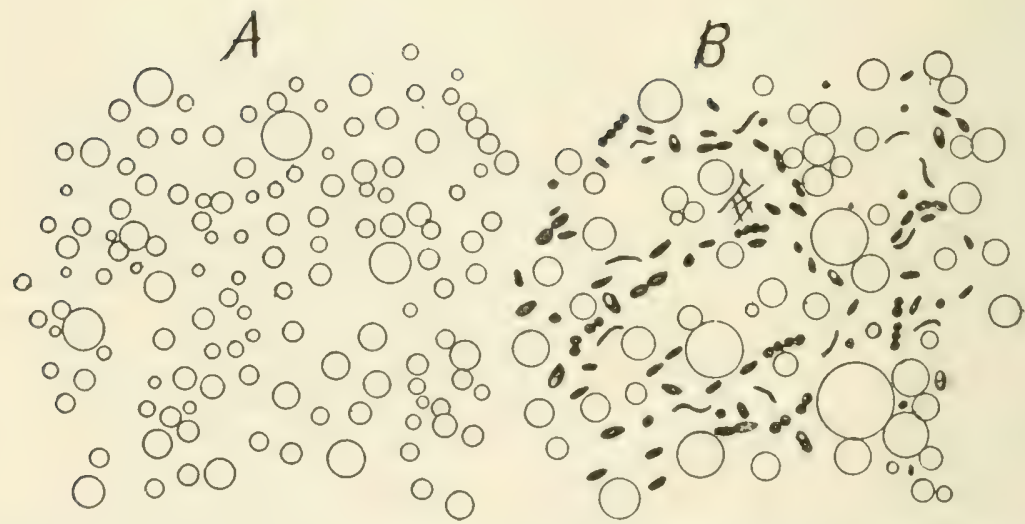

Microscopic appearance of pure and impure milk. A, Pure milk ; B, after standing in a wash room for a few hours in a dirty dish, showing, besides the fat globules, many forms of bacteria.--Moore. 


\section{CHAPTER XX.}

\section{SANITARY MILK PRODUCTION.}

Sanitary Milk Defined. Sanitary milk is milk from healthy cows, produced and handled under conditions in which contamination from filth, bad odors, and bacteria, is reduced to a minimum.

Importance of Sanitary Milk. The production of clean milk is one of the most important subjects that confronts the American dairyman at the present time. Further improvement in the quality of butter and cheese must largely be sought in the use of cleaner milk. With the better appreciation by the public of the great nutritive value of milk, there opens an unlimited market for it for consumption in the raw form. Already we find that milk produced under the best sanitary conditions sells for practically double that obtained under ordinary, more or less, slip-shod conditions. So great is the clamor for cleaner milk that any extra efforts expended in producing it are certain to be richly compensated.

The Necessary Conditions for the production of sanitary milk are as follows: (I) Healthy cows; (2) sanitary barn; (3) clean barn yard; (4) clean cows; (5) clean milkers; (6) clean milk vessels; (7) clean, wholesome feed; (8) pure water; (9) clean strainers; ( I0) dust-free stable air; (II) clean bedding; (I2) milking with dry hands; (I3) thorough cooling of milk after milking; (I4) sanitary milk room.

Healthy Cows. The health of the cow is of prime importance in the production of sanitary milk. All milk 
from cows affected with contagious diseases should be rigidly excluded from the dairy. Aside from the general unfitness of such milk there is danger of the disease producing organisms getting into the milk. It has been found, for example, that cows whose udders are affected with tuberculosis, yield milk containing these organisms. The prevalence of this disease among cows at present makes it imperative to determine definitely whether or not cows are affected with the disease, by the application of the tuberculin test.

Any feverish condition of the cow tends to impart a feverish odor to the milk, which should therefore not be used. Especially important is it that milk from diseased udders, no matter what the character of the disease, be discarded.

Sanitary Barn. Light, ventilation, and ease of cleaning are essential to a sanitary dairy barn. The disinfectant action of an abundance of sunlight, secured by providing a large number of windows, is of the highest importance.

Of equal importance is a clean, pure atmosphere, secured by a continuous ventilating system. The fact that odors of any description are absorbed by milk with great avidity, sufficiently emphasises the great need of pure air.

To permit of easy cleaning, the barn floors and gutters should be built of concrete. They should be scrubbed daily, and care should be taken to keep the walls and ceiling free from dust and cobwebs. The feed boxes must also be cleaned after each feed.

The stalls should be of the simplest construction, to afford as little chance for lodgement of clust as possible. Furthermore, they should so fit the cows as to cause the latter to stand with their hind feet on the edge of the gut- 
ter, a matter of the highest importance in keeping cows clean.

The walls and ceiling should be as smooth as possible. Moreover, they should be frequently disinfected by means of a coat of whitewash. The latter gives the barn a striking sanitary appearance.

Clean Barn Yard. A clean, well drained barn yard is an essential factor in the production of sanitary milk. Where cows are obliged to wade in mire and filth, it is easy to foretell what the quality of the milk will be. To secure a good barn yard it must be covered with gravel or cinders, and should slope away from the barn. If the manure is not taken directly from the stable to the fields, it should be placed where the cows cannot have access to it.

Clean Cows. Where the barn and barn-yard are sanitary, cows may be expected to be reasonably clean. Yet cows that are apparently clean, may still be the means of infecting milk to no small degree. When we consider that every dust particle and every hair that drops into the milk may add hundreds, thousands, or even millions of bacteria to it, we realize the importance of taking every precaution to guard against contamination from this source.

To keep cows as free as possible from loose hair and dust particles they should be carded and brushed regularly once a day. This should be done after milking to avoid dust. Five to ten minutes before the cow is milked her udder and flanks should be gently washed with clean, tepid water, by using a clean sponge or cloth. This will allow sufficient time for any adhering drops of water to drip off, at the same time it will keep the udder and flanks sufficiently moist to prevent dislodgment of dust particles 
and hairs at milking time. 'This practically means that the milker must always have one or two cows washed ahead. He should be careful to wash his hands in clean water after each washing.

Under ordinary conditions the cow is the greatest source of milk contamination. The rubbing of the milker against her and the shaking of the udder will dislodge numerous dust particles and hairs unless the foregoing instructions are rigidly followed.

Attention should also be given to the cow's switch, which should be kept scrupulously clean. The usual switching during milking is no small matter in the contamination of milk when the switch is not clean.

Clean Milkers. Clothes which have been worn in the fields are not suitable for milking purposes. Every milker should be provided with a clean, white milking suit, consisting of cap, jacket and trousers. Such clothes can be bought ready made for one dollar; and, if frequently laundered, will materially aid in securing clean milk.

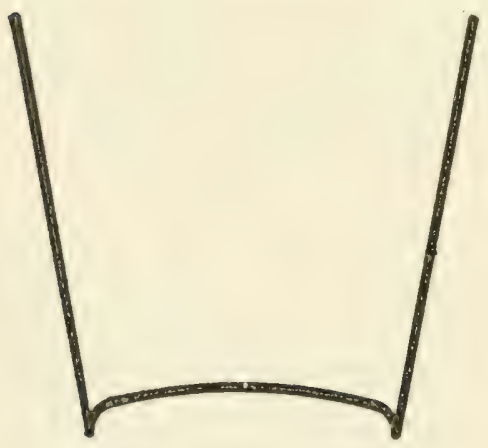

Fig. 42. Unflushed seam.

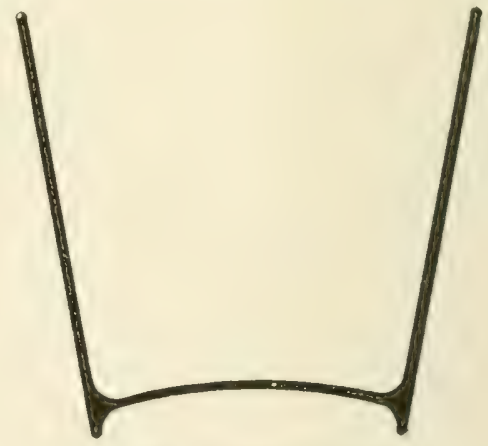

Fig. 43. Flushed seam.

Milkers should also wash and dry their hands before milking, and, above all, should keep them dry during milking.

Clean Vessels. All utensils used in the handling of 
milk should be made of good tin, with as few seams as possible. Wherever seams occur, they should be flushed with solder. Unflushed seams are difficult to clean, and, as a rule, afford good breeding places for bacteria. Fig. 42 illustrates the character of the unflushed seam ; Fig. 43 shows a flushed seam, which fully illustrates its value.

Fig. 44 illustrates a modern sanitary milk pail. The value of a partially closed pail is evident from the reduced opening, which serves to keep out many of the micro-organisms that otherwise drop into the pail during

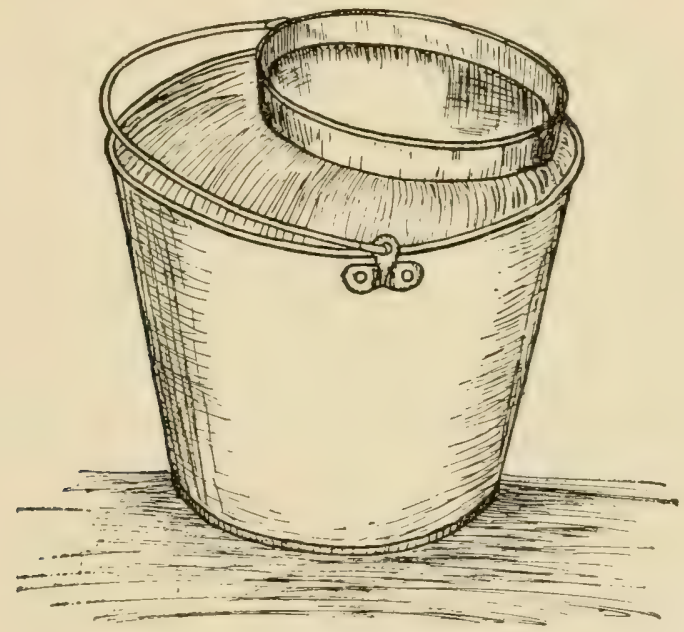

Fig. 44. Sanitary Milk Pail.

milking. While such a pail is somewhat more difficult to clean than the ordinary open pail, it is believed that the reduced contamination during milking far outweighs this disadvantage.

All utensils used in the handling of milk should be as nearly sterile as possible. A very desirable method of cleaning them is as follows:

First, rinse with warm or cold water. Second, scrub 
with moderately hot water containing some sal soda. The washing should be done with brushes rather than cloth because the bristles enter into any crevices present which the cloth cannot possibly reach. Furthermore, it is very difficult to keep the cloth clean. Third, scald thoroughly with steam or hot water, after rinsing out the water in which the sal soda was used. After scalding, the utensils should be inverted on the shelves without wiping and allowed to remain in this place until ready to use. This will leave the vessels in a practically sterile condition. Fourth, if it is possible to turn the inside of the vessels to the sun, in a place where there is no dust, then it is desirable to expose the utensils during the day to the strong germicidal action of the direct sun's rays.

Clean, Wholesome Feed. Highly fermented and aromated feeds, like sour brewers grains and leeks should be rigidly withheld from dairy cows when anything like good flavored milk is sought. So readily does milk absorb the odors of feeds through the system of the animal, that even good corn silage, when fed just previous to milking, will leave its odor in the milk. When fed after milking, however, no objection whatever can be raised against corn silage because not a trace of its odors is then found in the milk. Aromatic feeds of any kind should always be fed after milking.

Pure Water. Since feeds are known to transmit their odors to the milk through the cow, it is reasonable to expect water to do the same. Cows should, therefore, never be permitted to drink anything but pure, clean-flavored water. The need of pure water is further evident from the fact that it enters so largely into the composition of milk. 
The water of ponds and stagnant streams is especially dangerous. Not only is such water injurious to the health of cows, but in wading into it, they become contaminated with numerous undesirable bacteria, some of which may later find their way into the milk.

Strainers and Straining. Milk should be drawn so clean as to make it almost unnecessary to strain it. This operation is frequently done under the delusion that so long as it removes all visible dirt the milk has been entirely purified. The real harm, however, that comes from hairs and dust particles dropping into the milk is not so much in the hairs and dust particles themselves as in the millions of bacteria which they carry with them. These bacteria are so small that no method of straining will remove them. Straining can not even remove all of the dirt, because some of it will go in solution.

A good strainer consists of two thicknesses of cheese cloth with a layer of absorbent cotton between. The strainer is to be placed on the can or vat into which the milk is to be strained and not on the milk pail. While a strainer like the above placed upon the milk pail, reduces the bacterial content slightly in the hands of careful milkers, it is believed that the slight advantage gained would be more than off-set by greater carelessness in milking; especially might this be true with ignorant milkers who are apt to think that the strainer will make up for any carelessness on their part. A cheese cloth strainer on the milk pail is worse than useless with any kind of milker.

New sterilized cotton must be used at each milking and the cloths must be thoroughly washed and sterilized. Like the cotton, it is best to use the cloth but once.

Dust=Free Air. Great precaution should be taken not 
to create any dust in the stable about milking time, for this is certain to find its way into the milk. Cows should, therefore, never be bedded or receive any dusty feed just before or during milking.

Dry roughage, such as hay and corn fodder, always contains a considerable amount of dust, and when fed before or during milking may so charge the air with dust as to make clean milk an impossibility.

Moistening the floor and walls with clean water previous to milking materially minimizes the danger of getting dust into the milk. A mistake not infrequently made even in the better class of dairies is to card and brush the cows just before milking. While this results in cleaner cows, the advantage thus gained is far more than offset by the dirtier air, which, as will be shown later, materially increases the germ content of the milk. The carding and brushing should be done at least thirty minutes before the milking commences.

Clean Bedding. Clean shavings and clean cut straw should preferably be used for bedding. Cows stepping and lying on dirty bedding will soil themselves and create a dusty barn air.

Milking With Dry Hands. A prolific source of milk contamination is the milking with wet hands. Where the milker wets his hands with milk, some of it is bound to drip into the pail, carrying with it thousands or millions of bacteria, depending upon the degree of cleanliness of the milker's hands and the cow's udder. There is no excuse for the filthy practice of wet milking, since it is just as easy to milk with dry hands.

Fore=Milk. Where the purest milk is sought, it is desirable to reject the first stream or two from each teat, as this contains many thousands of hacteria. The reason 
for this rich development of germs is found in the favorable conditions provided by the milk in the milk-ducts of the teats, to which the bacteria find ready access.

Flies. Flies not only constitute a prolific but also a dangerous source of milk contamination. These pests visit places of the worst description and their presence in a dairy suggests a disregard for cleanliness. Of $4^{\mathrm{I}} 4$ flies examined by the Bacteriologist of the Connecticut Station, the average number of bacteria carried per fly was one and a quarter millions. Flies should be rigidly excluded from all places where they are apt to come in contact with the milk.

Experimental Data. To show to what extent the bacterial content of milk may be reduced by adopting the precautions suggested in the foregoing pages, a few experimental data are herewith presented.

In Bulletin No. 42 of the Storrs (Conn.) Experiment Station, Stocking reports the following:

I. When the cows were milked before feeding the number of bacteria per c. c. was I,233; when milked immediately after feeding, the number of bacteria was 3,656 , or three times as many.

2. When the udder and flanks of the cows were wiped with a damp cloth, the number of bacteria per c. c. was 716 ; when not wiped the number was 7,058 , or $t c n$ times as great.

3. When the cows were not brushed just before milking the number of bacteria per c. c. was $\mathrm{I}, 207$; when brushed just before milking, the number was 2,286 , or nearly twice as great.

4. When students who had studied the production of clean milk did the milking, the number of bacteria per c. c. was 914; when the milking was done by regular 
unskilled milkers the number of bacteria was 2.846 , or three times as great.

Wiping or washing udders before milking not only very materially recluces the bacterial content of the milk, but also lessens the amount of dirt to a very great extent. Frazer has shown that "the average weight of dirt which falls from muddy udders during milking is nincty times as great as that which falls from the same udder after washing, and when the udder is slightly soiled it is eighteen times as great."

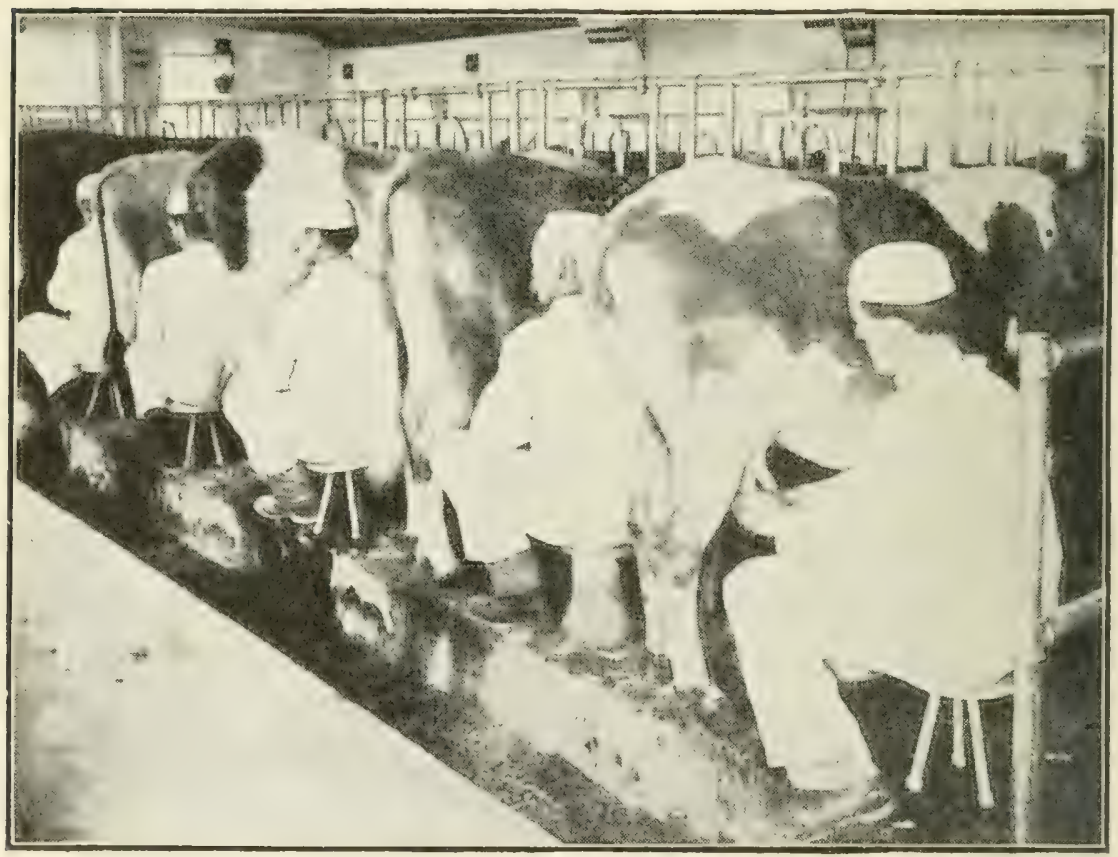

Fig. 45 - Clean Milking. (From Da. Div., U.S. Dept. of A.) 


\section{CHAPTER XXI.}

FARM BUT'TER-MAKING.

CREAMING.

Cause. Creaming is due to the difference in the specific gravity of the fat and the milk serum. The fat being light and insoluble rises, carrying with it some of the other constituents of the milk. The result is a layer of cream at the surface.

Processes of Creaming. The processes by which milk is creamed may be divided into two general classes: (I) That in which milk is placed in shallow pans or long narrow cans and allowed to set for about twenty-four hours, a process known as natural or gravity creaming; (2) that in which gravity is aided by subjecting the milk to centrifugal force, a process known as centrifugal creaming. The centrifugal force has the effect of increasing the force of gravity many thousands of times, thus causing an almost instantaneous creaming. This force is generated in the cream separator.

Shallow=Pan Method. The best results with this method are secured by straining the milk directly after milking into tin pans about twelve inches in diameter and two to four inches deep. It is then allowed to remain undisturbed at room temperature $\left(60^{\circ}\right.$ to $65^{\circ} \mathrm{F}$.) for twenty-four to thirty-six hours, after which the cream is removed either with a nearly flat, perforated skimmer, or by allowing it to glide over the edge of the pan after it has been carefully loosened along the sides. The average loss of fat in the skim milk by this method is $0.7 \%$. 
Deep=Cold=Setting Method. The best results with this method are secured by using a can like the Coolcy illustrated in Fig. 47. This can is provided with a cover

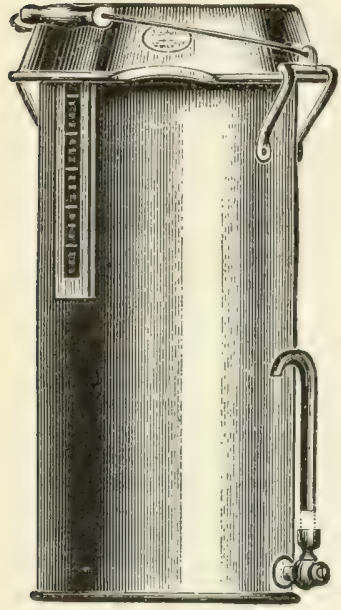

Fig. 47.- Cooley Can. which allows it to be submerged in water. It also has a spout at the bottom by which the skim milk is gently removed, thus preventing the partial mixing of cream and skim milk incident to skimming with a conical dipper.

The milk is put into the cans directly after milking and cooled to as low a temperature as possible. To secure the best results with this method the water should be iced. Where this is done the skim milk will show only about $0.2 \%$ fat. It it desirable to allow the milk to set twenty-four hours before skimming, though usually the creaming is quite complete at the end of twelve or fifteen hours.

Dilution or Aquatic Separators. One of the most unsatisfactory methods of creaming is the addition of water to the milk. The creaming by this method is done in variously constructed tin cans, which the manufacturers usually sell under the name of dilution or aquatic separators. Those uninformed about the genuine centrifugal separators are often lead to believe that they are buying real separators at a low cost when they are investing five, ten or fifteen dollars in one of these tin cans, which are no more entitled to the term separator than are the common shallow pans. The average loss of fat with this system of creaming is about $\mathrm{I} / 2 \%$. 
Centrifugal Method (Hand Separator). Dairies having four or more cows should cream their milk by the centrifugal method, the hand separator. The saving of butter fat with this method soon pays for the cost of a separator. Moreover it has the idditional advantages over the gravity methods of creaming in providing fresh, sweet skim milk for feeding purposes, and yielding cream of any desired richness.

Efficiency of Creaming With a Separator. Under favorable conditions a separator should not leave more than .05\% fat in the skim milk by the Babcock test There are a number of conditions that affect the efficiency of skimming and these must be duly considered in making a separator test. The following are some of these conditions :
A. Speed of bowl.
B. Steadiness of motion.
C. Temperature of milk.
D. Manner of heating milk.
E. Amount of milk skimmed per hour.
F. Acidity of milk.
G. Viscosity of milk.
H. Richness of cream.
I. Stage of lactation. (Stripper's milk.)

A. The greater the speed the more efficient the creaming, other conditions the same. It is important to see that the separator runs at full speed during the separating process.

B. A separator should run as smoothly as a top. The slightest trembling will increase the loss of fat in the skim milk. Trembling of bowl may be caused by any of the following conditions: ( I) loose bearings, (2) sepa- 
rator out of plumb, (3) dirty oil or dirty bearings, (4) unstable foundation, or (5) unbalanced bowl.

C. The best skimming is not possible with any separator when the temperature falls below $60^{\circ} \mathrm{F}$. A temperature of $85^{\circ}$ to $98^{\circ} \mathrm{F}$. is the most satisfactory for ordinary skimming. Under some conditions the cleanest skimming is obtained at temperatures above $100^{\circ} \mathrm{F}$. The reason milk separates better at the higher temperatures is that the viscosity is reduced.

D. Sudden heating tends to increase the loss of fat in skim-milk. The reason for this is that the fat heats more slowly than the milk serum, which diminishes the difference between their densities. When, for example, milk is suddenly heated from near the freezing temperature to $85^{\circ} \mathrm{F}$. by applying live steam, the loss of fat in the skim-milk may be four times as great as it is under favorable conditions.

E. Unduly crowding a separator increases the loss of fat in the skim-milk. On the other hand, a marked underfeeding is apt to lead to the same result.

F. The higher the acidity of milk the poorer the creaming. With sour milk the loss of fat in the skimmilk becomes very great.

G. Sometimes large numbers of undesirable (slimy) bacteria find entrance into milk and materially increase its viscosity. This results in very unsatisfactory creaming. Low temperatures also increase the viscosity of milk which accounts for the poor skimming at these temperatures.

H. Most of the standard makes of separators will do satisfactory work when delivering cream of a richness of $50 \%$. A richer cream is liable to result in a richer skim- 
milk. The reason for this is that in rich cream the skimmilk is taken close to the cream line where the skim-milk is richest.

I. Owing to the very small size of the fat globules in stripper's milk, such milk is more difficult to cream than that produced in the early period of lactation.

Regulating Richness of Cream. The richness of cream is regulated by means of a cream screw in the separator bowl. When a rich cream is desired the screw is turned toward the center of the bowl, and for a thin cream it is turned away from the center.

Advantages of Rich Cream. To separate a rich cream at the farm results in mutual benefit to producer and manufacturer. The main advantages are as follows: (I) Less bulk to handle; (2) less cream to cool; (3) less transportation charges; (4) more skim-milk for the farmer; (5) better keeping quality; (6) allows more starter to be added; (7) gives better results in churning, and (8) makes pasteurization easier, especially with sour cream.

Best Time to Separate Milk. The best results with a separator are obtained by running the milk through the machine immediately after milking.

Saving of Butter Fat with a Separator. That the owner of four good cows can afford to invest $\$ 50.00$ in a small cream separator is shown by the following: Four good cows will yield not less than 24,000 pounds of milk a year. By the common shallow pan method of creaming, the loss of butter fat will average 0.7 pound for every Ioo pounds of milk. With the centrifugal separator the loss of fat will not average over 0.05 pound, hence there will be effected a saving of 0.65 pound of 
butter fat in each Ioo pounds of milk by the use of the separator. At this rate, the total saving of butter fat annually on the 24,000 pounds of milk will be 156 pounds. Since each pound of butter fat will yield approximately I I-6 pounds of butter, I8 3 pounds of butter will be saved by the process, which, at 25 cents per pound, amounts to $\$ 45.75$. This saving in butter fat alone will almost pay for the separator in one year.

Fastening a Separator. To secure steady motion, the separator must be fastened to a solid foundation. There is nothing better in this respect than a concrete floor, with which every dairy should be provided.

One of the best methods of fastening separators to concrete floors is the use of expansion bolts.

These consist of lag screws with tapering points provided with malleable shields, having threads on their inner sides to fit the threads of the lag screws and projections on their outer sides to catch and hold in holes made in the concrete. The shields expand as the lag screw is screwed in.

CREAM RIPENING.

Cream ripening is a process of fermentation in which the lactic acid organisms play the chief role. In every-day language, cream ripening means the souring of the cream. So important is this process that the success or failure of the butter maker is largely determined by his ability to exercise the proper control over it. In common practice the time consumed in the ripening of cream varies from twelve to twenty-four hours.

Object. The ripening of cream has for its prime object the development of flavor and aroma in butter, two qualities usually expressed by the word flavor. In addi- 
tion to this, cream ripening has several minor purposes, namely: (I) renders cream more easily churnable; (2) obviates difficulties from frothing or foaming in churning; (3) permits a higher churning temperature; (4) increases the keeping quality of butter.

Flavor. This, so far as known at the present time, is the result of the development of the lactic fermentation. If other fermentations aid in the production of this important quality of butter, they must be looked upon as secondary. In practice the degree or intensity of flavor is easily controlled by governing the formation of lactic acid. That is, the flavor develops gradually with the increase in the acidity of the cream. Sweet cream butter, for example, is almost entirely devoid of flavor, while cream with an average richness possesses the maximum amount of good flavor possible when the acidity has reached $.6 \%$.

Churnability. Practical experience shows that sour cream is more easily churnable than sweet cream. This is explained by the fact that the development of acid in cream tends to diminish its viscosity. The concussion produced in churning causes the little microscopic fat globules to flow together and coalesce, ultimately forming the small granules of butter visible in the churn. A high viscosity impedes the movement of these globules. It is cvident, therefore, that anything that reduces the viscosity of cream, will facilitate the churning.

As a rule, too, the greater the churnability of cream the smaller the loss of fat in the buttermilk.

Frothing. Experience shows that ripened cream is less subject to frothing or foaming than unripened. This is probably due to the reduced viscosity of ripened cream and the consequent greater churnability of same. 
Temperature. Sour cream can be churned at higher temperatures than sweet cream with less loss of fat in the buttermilk. This is of great practical importance since it is difficult to get low enough temperatures for the successful churning of sweet cream.

Keeping Quality. It has been found that butter with the bast keeping quality is obtained from well ripened cream. It is true, however, that butter made from cream that has been ripened a little too far will possess very poor keeping quality. An acidity of .5\% should be placed as the limit when good keeping quality is desired.

CONTROL OF THE RIPENING PROCESS.

We have learned that the highly desirable flavor and aroma of butter are produced by the development of the lactic fermentation. In the following discussion we shall take up the means of controlling this fermentation and treat of the more mechanical side of cream ripening. This will include: (I) the ripening temperature; (2) time in ripening; (3) agitation of cream during ripening.

Ripening Temperature. Since the lactic acid bacteria develop best at a temperature of $90^{\circ}$ to $98^{\circ} \mathrm{F}$. it would seem desirable to ripen cream at these temperatures. But this is not practicable because of the unfavorable effect of high temperatures on the body of the cream and the butter. Good butter can be produced, however, under a wide range of ripening temperatures. The limits may be placed at $60^{\circ}$ and $80^{\circ}$. Temperatures below $60^{\circ}$ are too unfavorable for the development of the lactic acid bacteria. Any check upon the growth of these germs increases the chances for the development of other kinds of bacteria. But it may be added that when cream has reached an 
acidity of $.4 \%$ or more, the ripening may be finished at a temperature between $55^{\circ}$ and $60^{\circ}$ with good results. In general practice a temperature between $60^{\circ}$ and $70^{\circ}$ gives the best results. This means that the main portion of the ripening is done at this temperature. The ripening is always finished at temperatures lower than this.

Time in Ripening. As a rule quick ripening gives better results than slow. The reason for this is evident. Quick ripening means a rapid development of the lactic fermentation and, therefore, a relatively slow development of other fermentations. Practical experience shows us that the growth of the undesirable germs is slow in proportion as that of the lactic is rapid. For instance, when we attempt to ripen cream at $55^{\circ} \mathrm{F}$., a temperature unfavorable for the growth of the lactic acid bacteria, a more or less bitter flavor is always the result. This is so because the bitter germs develop better at low temperatures than the lactic acid bacteria.

Stirring Cream. It is very essential in cream ripening to agitate the cream frequently to insure uniform ripening. When cream remains undisturbed for some time the fat rises in the same way that it does in milk, though in a less marked degree. The result is that the upper layers are richer than the lower and will sour less rapidly, since the action of the lactic acid germs is greater in thin than in rich cream.

This uneven ripening leads to a poor bodied cream. Instead of being smooth and glossy, it will appear coarse and curdy when poured from a dipper. The importance of stirring frequently during ripening should therefore not be underestimated.

The Use of Sour Milk (Starter). Cream produced under cleanly conditions ordinarily contains many kinds 
of bacteria-good, bad, and indifferent-and to insure a large predominance of the lactic acid type in the ripening process, it is necessary to reinforce the bacteria of this type already existing in the cream by adding large quantities of them in a pure form, that is, unmixed with undesirable species. Clean flavored sour milk or skim milk at the point of curdling is practically a pure culture of lactic acid organisms, and the addition of about io pounds of such milk to every IOO pounds of cream will result in a better and more uniform quality of butter.

Amount of Acid to Develop. Crean of average ricnness should have an acidity of from 0.5 to 0.6 per cent. when churned. A rich cream requires less acid than a thin cream.

Sweet and Sour Cream. In small dairies, where only a few churnings are made weekly, care should be taken never to mix sweet and sour cream just before churning. This always results in a heavy loss of fat in the buttermilk on account of the difference in the churnability of sweet and sour cream.

\section{$\triangle C I D$ TEST FOR CREAM.}

Butter makers do not find it safe to rely upon their noses in determining the ripeness of cream for churning. They use in daily practice tests by which it is possible to determine the actual amount of acid present. The method of using these tests is based upon the simplest form of titration, which consists in neutralizing an acid with an alkali in the presence of an indicator which determines when the point of neutrality has been reached.

In the tests for acidity of cream the alkali used is sodium lyctroxide. This is made ap) of a definite strength 
so that the amount of acid can be calculated from the amount of alkali used.

Farrington's Alkaline Tablet Test. In this test the alkali is used in a dry tablet form in which it is easily handled. Each tablet contains enough alkali to neutralize .034 gram of lactic acid.

Apparatus Used for the Test. This is shown in Fig. 48 , and consists of a porcelain cup, one I7.6 c.c. pipette, and a Ioo c.c. rubber-stoppered, graduated glass cylinder.

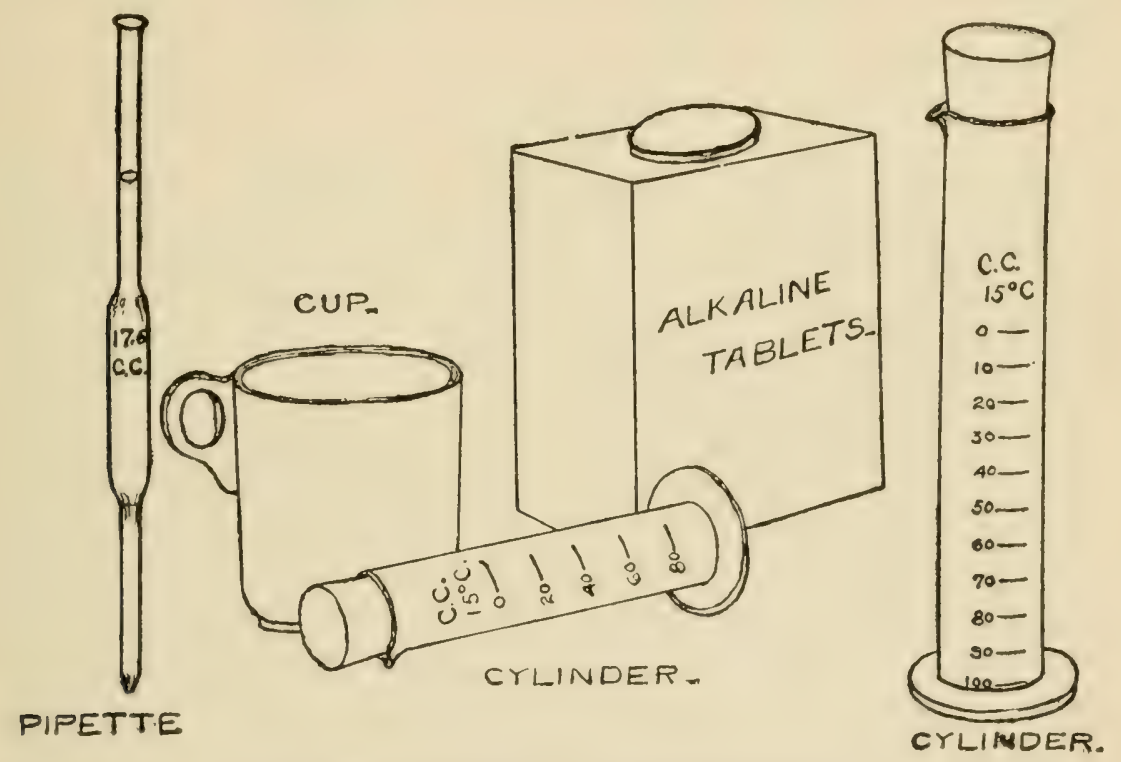

Fig. 48. Farrington Acid Test Apparatus.

Making the Solution. The solution is made in the graduated cylinder by dissolving 5 tablets in enough water to make 97 c.c. solution. When the tablets are dissolved, which takes from six to twelve hours, the solution should be well shaken and is then ready for use. The solution of the tablets may be hastened by placing the graduate in a reclining position, as shown in the cut. 
Making the Test. With the pipette add I7.6 c.c. of cream to the cup, then with the same pipette add an equal amount of water. Now slowly add of the tablet solution, rotating the cup after each addition. As soon as a permanent pink color appears, the graduate is read and the number of c.c. solution used will indicate the number of hundredths of one per cent of acid in the cream. Thus, if it required 50 c.c. of the tablet solution to neutralize the cream then the amount of acid would be $.50 \%$. From this it will be seen that with the Farrington test no calculation of any kind is necessary.

\section{CHURNING.}

Theory. Under the physical properties of butter fat it was mentioned that this fat existed in milk in the form of extrencly minute globules, numbering about I0O,ooo,ooo per drop of milk. In rich cream this number is increased at least a dozen times owing to the concentration of the fat globules during the separation of the milk.

So long as milk and cream remain undisturbed, the fat remains in this fincly divided state without any tendency whatever to flow together. This tendency of the globules to remain separate was formerly ascribed to the supposed presence of a membrane around each globule. Later researches, however, have proven the falsity of this theory and we know now that this condition of the fat is due to the surface tension of the globules and to the dense layer of casein that surrounds them.

Any disturbance great enough to cause the globules to break through this caseous layer and overcome their surface tension will cause them to unite or coalesce, a process which we call chuming. In the churning of cream this 
process of coalescing continues until the fat globules have united into masses visible in the churn as butter granules.

CONDITIONS THAT INFLUENCE CHURNING.

There are a number of conditions that have an important bearing upon the process of churning. These may be enumerated as follows:

I. Temperature.

2. Character of butter fat.

3. Acidity of cream.

4. Richness of cream.

5. Amount of cream in churn.

6. Speed of churn.

7. Abnormal fermentations.

I. Temperature. To have the miscroscopic globules unite in churning they must have a certain degree of softness or fluidity, which is greater the higher the temperature. Hence the higher the temperature, within certain limits, the quicker the churning. To secure the best results the temperature must be such as to churn the cream in from thirty to forty-five minutes. This is brought about in different creams at quite different temperatures.

The temperature at which cream must be churned is determined primarily by the character of the butter fat and partly also by the acidity and richness of the cream. Most cream is churned between 55 and 60 degrees Fahr.

Rule for Churning Temperature. A good rule to follow with regard to temperature is this: When the cream enters the churn with a richness of 30 per cent and an acidity of .5 to .6 per cent, the temperature should be such that the cream will churn in from thirty to fortyfive minutes. This will insure an exhaustive churning and leave the butter in a condition in which it can be 
handled without injuring its texture. Moreover, the buttermilk can then be easily removed, so that when a plug is taken with a trier the day after it is churned the brine on it will be perfectly clear.

2. Character of Butter Fat. The fat globules in cream from different sources and at different times have the proper fluidity to unite at quite different teniperatures. This is so because of the differences in the relative amount of "soft" and "hard" fats of which butter fat is composed. When the hard fats largely predominate the butter fat will, of course, have a high melting point. Such fat may be quite hard at a temperature of $60^{\circ}$, while a butter fat of a low melting point would be comparatively soft at this temperature. For a study of the conditions that influence the hardness of butter fat the reader is referred to the discussion of the "insoluble fats" treated in the chapter on milk.

3. Acidity of Cream. 'This has a marked influence on the churning process. Sour or ripened cream churns with much greater ease than sweet cream because the acid renders it less viscous. The ease with which the fat globules travel in cream becomes greater the less the viscosity. Ripe cream will therefore always churn more quickly than sweet cream. Ripe cream also permits of a higher churning temperature than sweet, which is of great practical importance where it is difficult to secure low churning temperatures.

4. Richness of Cream. It may naturally be inferred that the closer the fat globules are together the more quickly they will unite with the same amount of concussion. In rich cream the globules are very close together, which renders it more easily churnable than thin cream. 
The former can therefore be churned in the same length of time at a lower temperature than the latter.

The ideal richness is about $30 \%$. A cream much richer than this will stick to the sides of the churn, which reduces the amount of concussion. The addition of water to the churn will overcome this stickiness and cause the butter to come in a reasonable length of time. It is better, however, to avoid an excessive richness when a exhaustive churning is to be expected.

5. Amount of Cream in Churn. The bes: and quickest churning is secured when the churn is

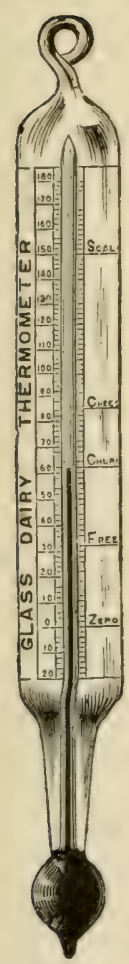

Fig. 49 .

Dairy Thermometer. one-third full. With more or less cream than this, the amount of concussion is reduced and the length of time in churning correspondingly increased.

6. Speed of Churn. The speed of the churn should be such as to produce the greatest possible agitation or concussion of the cream. Too high or too low a speed reduces the amount of concussion. The proper speed for each particular churn must be determined by experiment.

7. Abnormal Fermentations. The slimy or ropy fermentation sometimes causes trouble in churning by rendering the cream excessively viscous. Cream from single herds may become so viscous as to render churning impossible.

Dairy Thermometer. One of the essentials in making good butter is a thermometer like that shown in Fig. 49. It is necessary to ing ripening, and to secure uniform and exhaustive 
churnings the temperature of the cream must always be definitely known before it enters the churn.

\section{CHURNING OPERATIONS.}

Churns. Of the numerous styles of churns upon the market there is none better than the barrel churn. For large dairymen, however, who have 50 or more cows, a combined churn and butter worker is recommended. Such churns, or course, require some form of power to run them, and no large dairy is expected to be without power.

Preparing the Churn.

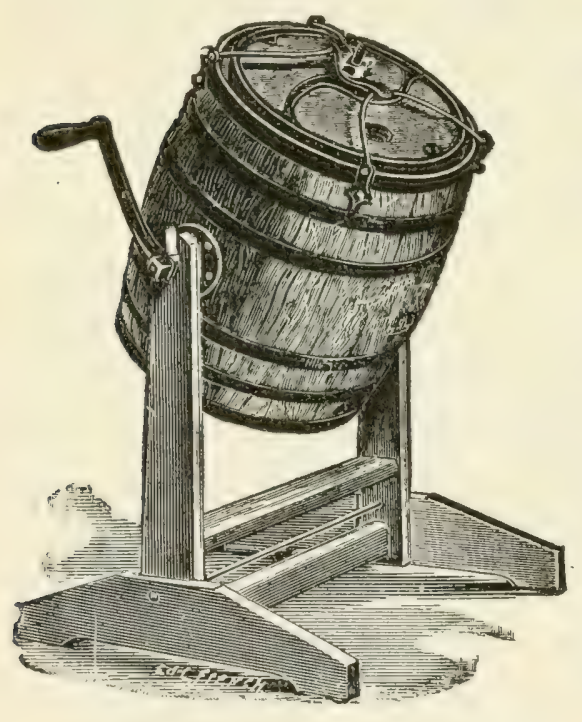

Fig. 50.-Barrel Churn.

Before adding the cream, the churn should be scalded with hot water and then thoroughly rinsed with cold water. This will "freshen" the churn and fill the pores of the wood with water so that the cream and butter will not stick.

Straining Cream. All cream should be carefully strained into the churn. This removes the possibility of white specks in butter which usually consist of curd or dried particles of cream.

Adding the Color. The amount of color to be added depends upon the kind of cream, the season of the year and the market demands.

Jersey or Guernsey cream requires much less color than Holstein because it contains more natural color. 
During the summer when the cows are feeding on pastures the amount of color needed may be less than half that required in the winter when the cows are feeding on dry feed.

Different markets demand different shades of color. The butter must therefore be colored to suit the market to which it is shipped.

In the winter time about one ounce of color is required per one hundred pounds of butter. During the summer less than one-half ounce is usually sufficient.

In case the color is not added to the crean (through an oversight) it may be added to the butter at the time of working by thoroughly mixing it with the salt. IVhen the colored salt has been evenly distributed through the butter the color will also be uniform throughout.

Gas in Churn. During the frrst five minutes of churning the vent of the churn should be opened occasionally to relieve the pressure developed inside. This pressure according to Babcock, "is chiefly due to the air within becoming saturated with moisture and not to gas set free from the cream."

Size of Granules. Butter should be churned until the granules are about half the size of a pea. When larger than this it is more difficult to remove the buttermilk and distribute the salt. When smaller, some of the fine grains are liable to pass out with the buttermilk, and the percentage of water in the butter is reduced. When the granules have reached the right size, cold water may be added to the churn to cause the butter to float better. Salt will answer the same purpose. The churn is now given two or three revolutions and the buttermilk drawn off.

Washing Butter. One washing in which as much water is used as there was cream is usually sufficient. 
When butter churns very soft two washings may be advantageous. Too much washing is dangerous, however, as it removes the delicate flavor of the butter.

Too much emphasis cannot be laid upon the importance of using clean, pure water for washing. Experiments have shown that impure water seriously affects the flavor of butter. When the water is not perfectly pure it should be filtered or pasteurized.

Salting. It is needless to say that nothing but the best grades of salt should be used in butter. This means sall readily soluble in water and free from impurities. If ther 2 is much foreign matter in salt, it will leave a turbid appearance and a slight sediment when dissolved in a tumbler of clear water.

Object of Salting. Salt adds flavor to butter and materially increases its keeping quality. Very high salting, however, has a tendency to detract from the fine, delicate aroma of butter while at the same time it tends to cover up slight defects in the flavor. As a rule a butter maker will find it to his advantage to be able to salt his butter rather high.

Rate of Salt. The rate at which butter should be salted, other conditions the same, is dependent upon market demands. The butter maker must cater to the markets with regard to the amount of salt to use as he does with regard to color.

The rate of salt used does not necessarily determine the amount contained in butter. For instance it is perfectly possible under certain conditions to get a higher percentage of salt in butter by salting at the rate of one ounce per pound than is possible under other conditions by salting at the rate of one and a half ounces. This means that under some conditions of salting more salt is lost than under others. 
The amount of salt retained in butter is dependent upon :

I. Amount of drainage before salting.

2. Fineness of butter granules.

3. Amount of butter in churn.

I. When the butter is salted before the wash water has had time to drain away, any extra amount of water remaining will wash out an extra amount of salt. It is good practice, however, to use a little extra salt and drain less before adding it as the salt will dissolve better under these conditions.

2. Small butter granules require more salt than large ones. The reason for this may be stated as follows: The surface of every butter granule is covered with a thin film of water, and since the total surface of a pound of small granules is greater than that of a pound of larger ones, the amount of water retained on them is greater. Small granules have therefore the same effect as insufficient drainage, namely, washing out more salt.

3. Relatively less salt will stick to the churn in large churnings than in small, consequently less will be lost.

Standard Rate. The average amount of salt used in butter is one ounce per pound.

\section{WORKING BU'T'TER.}

Object. The chief object in working butter is to evenly incorporate the salt. It also assists in expelling any surplus moisture.

How to Work Butter. Where only a small amount of butter is made, the butter may be worked with a ladle in the churn. For larger amounts it is desirable, however. to have a separate worker like that shown in Fig. ${ }^{6}$. 


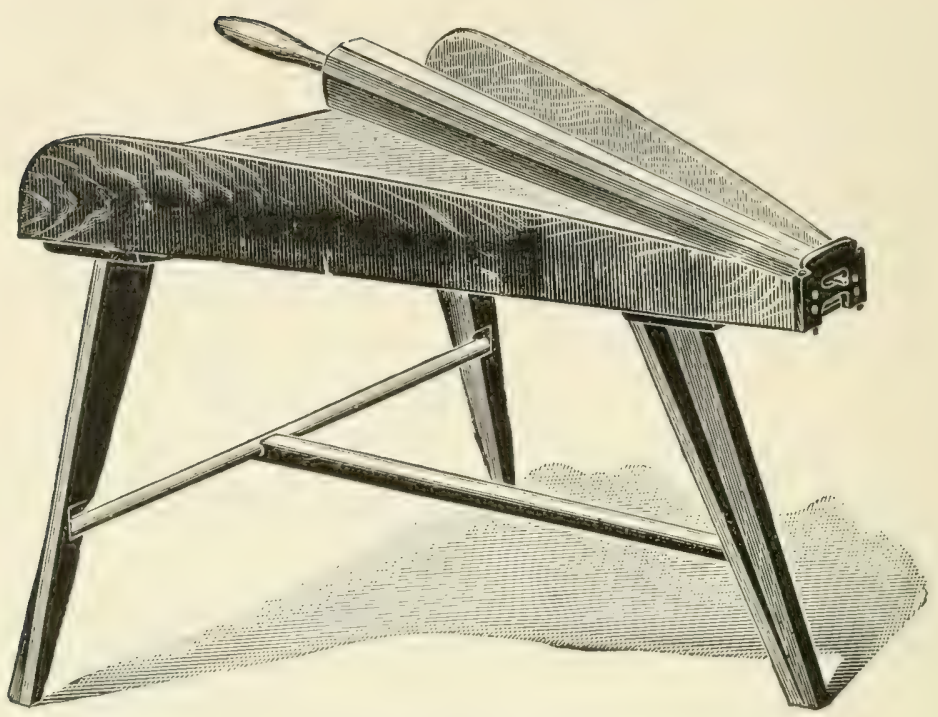

Fig. 51. Butter worker.

Butter is worked enough when the salt has been evenly distributed. Just when this point has been reached can not always be told from the appearance of the butter immediately after working. But after four or six hours' standing the appear-

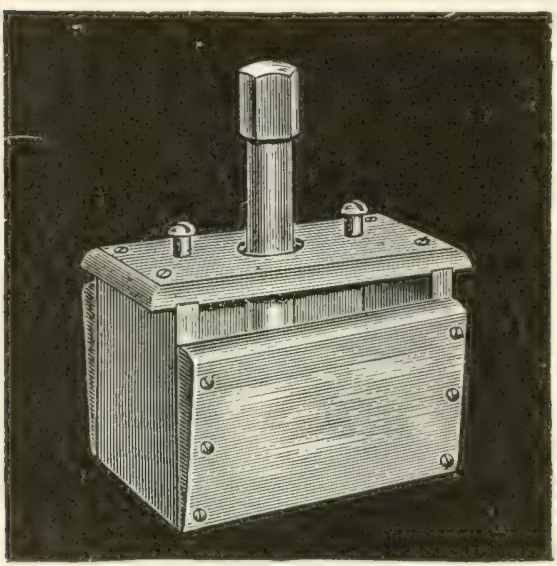

Fig. 52, - Butter Priuter. ance of white streaks or mottles indicates that the butter has not been sufficiently worked. The rule to follow is to work the butter just enough to prevent the appearance of mottles. To avoid mottles it is best to work butter twice. The first time, it is worked 
just enough to fairly incorporate the salt. It is then allowed to stand six or eight hours, after which white streaks are usually noticeable on cutting the butter with a string. The second working should cease as soon as these streaks or mottles have been removed.

Difficult Churning. The causes of trouble in churning may be enumerated as follows: ( I) thin cream, (2) low temperature, (3) sweet cream, (4) high viscosity of cream, (5) churn too full, (6) too high or too low speed of churn, (7) colostrum milk, (8) advanced period of lactation, and (9) abnormally rich cream.

Foaming. This is usually due to churning a thin cream at too low a temperature, or to a high viscosity of the cream. When caused by these conditions foaming can usually be overcome by adding warm water to the churn. Foaming may also be caused by having the churn too full, in which case the cream should be divided and two churnings made instead of one.

Cleaning Churns. After the butter has been removed, the churn sliould be washed, first with moderately hot water, next with boiling hot water containing a little alkali, and finally with hot water. If the final rinsing is done with cold water the churn dries too slowly, which is apt to give it a musty smell. This daily washing should be supplemented occasionally with a washing with lime water.

Nothing is equal to the cleansing action of well prepared lime water and its frequent use will prevent the peculiar churn odor that is bound to develop in churns not so treated.

The outside of the churn should be thoroughly cleaned with morlerately hot water containing a small amount of alkali. 
MARKETING BUTTER.

For fancy trade, one-pound prints wrapped in parchment paper are the most popular. These prints are made with a small hand printer (Fig. 54) which should have the dairyman's monogram cut into it. The imprint of the monogram in the butter will serve as a guarantee of its gentineness. It is also desirable to

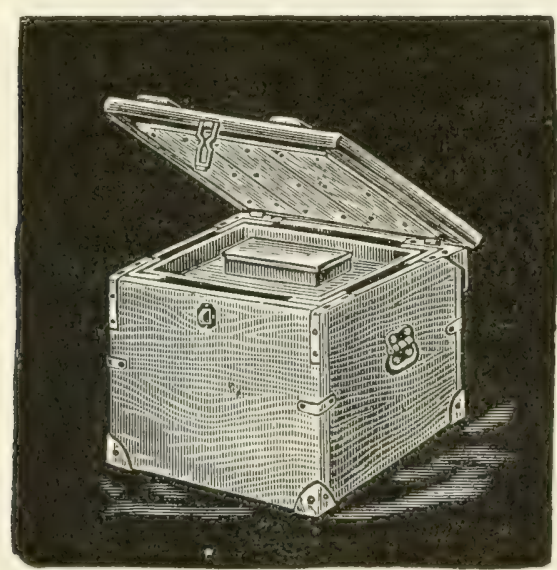

Fig. 53.-Print Butter Box.

have some neat lettering on the parchment wrapper, such, for example, as Fancy Dairy Butter, Cold Spring Dairy Butter, Golden Jersey Butter, etc. Prints must be kept cold to preserve their attractive rectangular appearance. The best prices for butter are realized by selling it direct to the consumer. With dairymen wio retail mills 
and cream, this method of marketing not only yields the best prices, but is also the most convenient, because the butter can be disposed of at the same time as the milk and cream.

A covered box like that shown in Fig. 55 is best adapted for carrying print butter to market. Ice may be packed in the box with the butter during warm weather.

With the small butter producer the greatest trouble is finding a suitable market for his product. It is customary with most of these producers to sell their butter to the country grocer, who, as a rule, makes little discrimination in the quality of the butter, the good and the poor selling for practically the same price. No producer of good butter can afford to market his butter in the country stores. Those who have made farm butter-making a success have invariably catered to private trade, or have sold their butter to well-known butter dealers. A great deal of butter could be sold in villages, towns, and cities at 25 and 30 cents a pound which would bring only I2 or 15 cents in the country stores. Seek, therefore, private customers who are willing to pay for a good product, and if these are not within easy reach by road, try to reach them by rail.

Composition of Butter. According to analysis reported by various experiment stations, American butter has the following average composition:

Per cent.

Water .................. I3

Fat $\ldots \ldots \ldots \ldots \ldots \ldots \ldots \ldots \ldots \ldots \ldots$

Proteids $\ldots \ldots \ldots \ldots \ldots \ldots \ldots$ I

Salt $\ldots \ldots \ldots \ldots \ldots \ldots \ldots \ldots \ldots \ldots, 3$ 


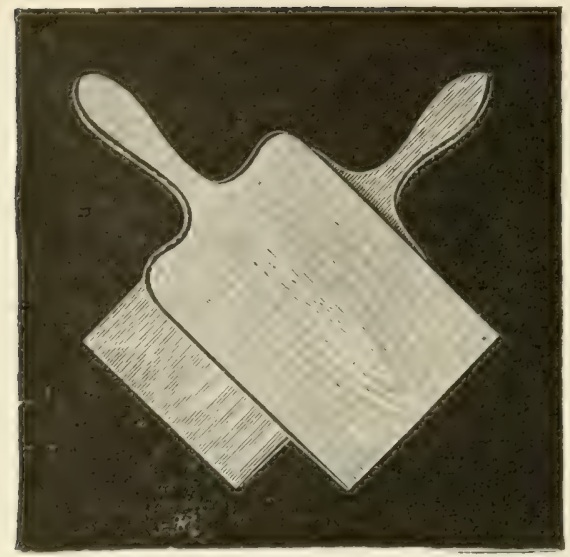

Fig. 54.-Butter Ladles.

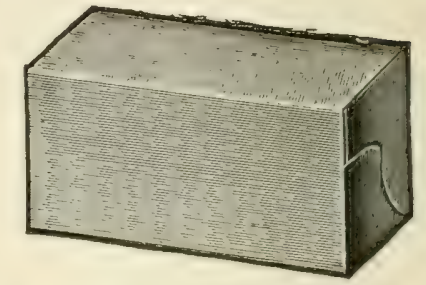

Fig. 55.-Butter Carton for Wrapping One-pound Butter Prints. 


\section{CHAPTER XXII.}

FARM CHEESEMAKING.

Apparatus and Materials Needed. For dairies from Io to 75 cows, the following list is recommended: Steam heating cheese vat; boiler; $13 / 4$ inch press screws; cheese hoops; horizontal and perpendicular cheese knives; one gallon dipper; curd scoop; whisk broom; Ioo cubic centimeter graduate; acid test; dairy thermometer ; rennet extract; cheese color; cheese salt; bandages; press cloths; cheese cloth circles, and a small scales.

Ripening the Milk. Place the night's and morning's milk in the cheese vat and heat to a temperature of $86^{\circ} \mathrm{F}$. Next determine the acidity of the milk with the Farrington test described on page I75. (Other tests may be used.) If less than $0.18 \%$ acid is found, the milk should be held to develop more acid. If very sweet it is desirable to add one or two pounds of good flavored, sour milk (starter, see p. I73) per Ioo pounds. A good starter will not only hasten the ripening but will improve the flavor of the cheese.

Adding Color and Rennet Extract. As soon as the milk shows an acidity of $0.18 \%$ to $0.2 \%$ add color at the rate of one ounce ( 30 c. c.) per I,000 pounds of milk and thoroughly mix. The amount of color to be used depends upon the season of the year, the market demands and the kind of milk. After the color is thoroughly incorporated, add rennet extract (curdling agent) at the rate of about four ounces (I2O c. c.) per I,O0O pounds of milk. The rennet extract should be diluted with water to the extent 
of four or five times its own volume before adding it to the milk. After the rennet extract has been thoroughly stirred in, the milk should be allowed to stand undis-

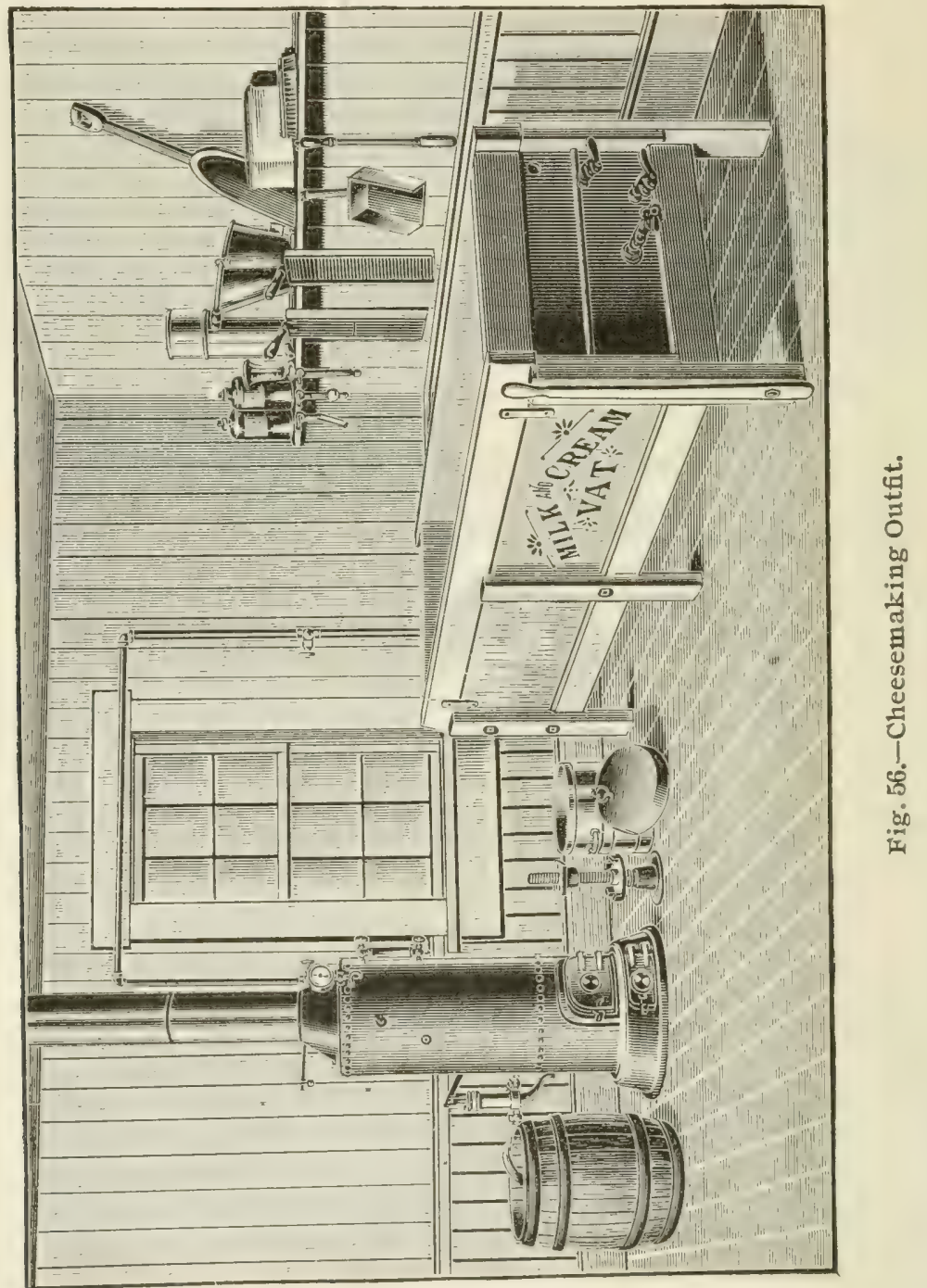

turbed until sufficiently curdled to cut. The temperature at the time of adding the rennet should be $86^{\circ}$ to go $\mathrm{F}$. 
The amount of rennet extract to be used is determined by the quickness with which the cheese is to ripen. If a quick ripening cheese is wanted, add 6 ounces per I,000 pounds of milk. If a slow ripening cheese is desired, add 3 ounces for $\mathrm{I}, \mathrm{OOO}$ pounds.

Cheese color and rennet extract are usually placed upon the market in liquid form. They are, however, also procurable in dry, tablet form in which they are preferred for making cheese on a small scale.

Cutting the curd. To determine when the curd is ready to cut, insert the forefinger, slightly break the curd with the thumb, and move the finger in the direction of the break and parallel to, and half an inch below, the surface. If the whey in the break is clear, the curd is ready to cut; if milky, the curdling has not progressed far enough. The cutting is done as follows: First cut the curd in horizontal layers with the horizontal knife; next cut lengthwise and crosswise, alternately, with the perpendicular knife until the curd cubes are about threeeighths of an inch on a side.

Warming and Stirring the Curd. Immediately after cutting, stir the curd very gently, yet enough to prevent the particles from matting together. Run the palm of the hand along the sides and bottom of the vat to remove any adhering curd. After 10 minutes stirring, gradually apply heat and bring the temperature to $100^{\circ} \mathrm{F}$. in about 30 minutes. After this temperature has been reached, the curd may be stirred at intervals of Io minutes until ready to remove the whey. It is important to keep the temperature as close to $100^{\circ} \mathrm{F}$. as possible.

Drawing off the Whey. When a bunch of curd is pressed between the two hands and on relieving the pressure the particles fall apart readily, the curd is ready for 
the removal of the whey. When this firmness is reached, the whey should show about $0.17 \%$ acid. When the milk is set at the proper ripeness, the degree of firmness and amount of acid indicated above are reached in about two and one-half hours after adding the rennet extract.

Remove the whey through a faucet or by means of a siphon. Place a perforated wooden rack about two inches high at one end of the vat and cover it with a piece of muslin or cheese cloth. Scoop the curd upon the rack and stir. The rack has the advantage of draining the curd quickly and also permits the use of hot water under the curd to assist in keeping the temperature at $98^{\circ} \mathrm{F}$., a temperature which should be maintained up to within Io or 15 minutes of salting.

If a rather moist, open textured cheese is desired, stir 30 minutes after the removal of the whey and salt. In case a firm, close-textured cheese is wanted, the curd must be stirred at frequent intervals for a period of about two hours before salting, so as to allow more acid to develop. A firm cheese is especially desirable during warm weather because of its superior keeping quality.

When the milk is not of uniformly good quality, and when an especially close-textured and uniform cheese is desired, the curd should be allowed to mat upon the racks. This is accomplished as follows: As soon as removed from the whey the curd is stirred a few minutes, sprearl about six inches deep upon the rack, and then allowed to mat I 5 minutes, after which it is cut into strips about 8 by 12 inches and then turned. After another 15 minutes, turn again and pile the strips two layers deep; i5 minutes later turn again and pile three layers deep. Usually after one and a half to two hours matting the curd tears like chicken breast, which indicates that it is 
ready to cut into little strips the size of a finger. This done, the curd is stirred about 30 minutes and then salted.

Salting. If a fast-curing cheese is desired, salt at the rate of $2 \frac{1}{4}$ pounds of salt per 100 pounds of curd. When a slow-ripening cheese is desired salt at the rate of $23 / 4$ pounds. Use only the best grade of salt, and have the curd at a temperature of about $90^{\circ} \mathrm{F}$. at the time of salting.

Molding and Pressing. Twenty to thirty minutes after salting, the curd is ready for the hoops (molds) which are prepared as follows: Place a piece of muslin in the bottom of the hoop and on top of this a cheese cloth circle somewhat less in diameter than the hoop. Now place the bandage on the bandager so that when the latter is in position the bandage will lap slightly over the cheese cloth circle in the bottom of the hoop. Next put in the curd. This done, cover with a piece of muslin and put on the cover (follower). Apply pressure very gradually at the start and do not apply full pressure (about $20 \mathrm{lbs}$. to the square inch) until after 20 to 30 minutes' pressing. Shortly after full pressure has been applied, remove the follower, the muslin cloth, and bandager. Turn the projecting bandage over onto the cheese. Next place a cloth circle over the top, replace the muslin and bandager, and then apply full pressure for about I2 hours, when the cheese is taken out of the hoop, any folds or irregularities in the bandage are straightened out, the cheese is washed off with hot water, and put back into the hoop inverted. Press about ten hours longer and remove the cheese from the hoop and put it into a suitable place for curing. Leave the cheese cloth circles on the cheese. 
Ripening or Curing. After leaving the press the cheese should be placed in a cool, damp room with ample ventilation. Keep the temperature as near $60^{\circ} \mathrm{F}$. as possible. The curing or ripening process, which consists of the transformation of insoluble into soluble casein, requires from two to eight months, according to the amount of rennet extract and salt used, amount of moisture in the cheese, and the temperature at which it is ripened. The higher the temperature and moisture, the quicker the cheese will ripen. During the first three weeks the cheese should be turned and rubbed daily, and if any portion of it is not covered with cheese cloth, grease should be applied to prevent cracking. If the curing room is dry, the cheese "should be covered with a thin layer of paraffine about a week after it is made, to prevent excessive loss of moisture.

Composition. Cured cheddar cheese has the following average composition: Water, $34 \%$; fat, $36.5 \%$; proteids, $26 \%$; and ash, $3.5 \%$. 


\section{CHAP'TER XXIII.}

STARTERS.

Definition. Starter is the general term applied to cultures of lactic acid organisms, whether they have been selected artificially in a laboratory, or at dairies by picking out milk that seems to contain these organisms to the exclusion of others. A good starter may be defined as a clean flavored batch of sour milk or sour skim-milk.

The word starter derives its name from the fact that a starter is used to "start" or assist the development of the lactic fermentation in cream ripening.

Object of Starters. Cream and milk ordinarily contain many kinds of bacteria-good, bad, and indifferent -and to insure the predominance of the lactic acid type in the ripening process it is necessary to reinforce the bacteria of this type already existing in the cream or milk by adding large quantities of them in a pure form, that is, unmixed with undesirable species.

The bacterial or plant life of cream may be aptly compared with the plant life of a garden. In both we find plants of a desirable and undesirable character. The weeds of the garden correspond to the bad fermentations of cream. If the weeds get the start of the cultivated vegetables, the growth of the latter will be checked or suppressed. So with the bacterial fermentations of cream. When the lactic acid bacteria predominate, other fermentations will be checked or crowded out. The 
use of a liberal amount of starter nearly always insures a majority of good bacteria and the larger this majority the better the product.

\section{NATURAL, STARTERS.}

Natural starters are those obtained by allowing milk or skim-milk to sour in the ordinary way. If the milk or skim-milk is produced and handled under cleanly conditions, it will have a fairly good flavor when soured to the point of thickening. But it is difficult, even under cleanly condition, to get uniformly good flavored sour milk or skim-milk by allowing it to sour in the usual way and for this reason the following method of preparing natural starters should be given preference.

Selected Natural Starters. The most satisfactory natural starters are selected and prepared in the following manner: Secure, say, one quart of milk from each of half a dozen healthy cows not far advanced in lactation, and fed on good feed. Before drawing the milk, brush the flanks and udders of the cows and then moisten them with water, or preferably, coat thinly with vaseline to prevent dislodgment of dust. Then, after rejecting the first few streams, draw the milk into sterilized quart jars provided with narrow necks. Now allow the milk to sour, uncovered, in a clean, pure atmosphere at a temperature between $65^{\circ}$ and $90^{\circ} \mathrm{F}$. When loppered pour off the top and introduce the sample with the best flavor into about forty pounds of sterilized skim-milk and sour at a temperature of about $70^{\circ} \mathrm{F}$.

A starter thus selected can be propagated for a month or more by daily inoculating newly sterilized or pasteurized milk with a small amount of the old or mother 
starter. Usually three or four pounds of the mother starter added to one hundred pounds of pasteurized skimmilk will sour it in twenty-four hours at a temperature of $65^{\circ} \mathrm{F}$. Under certain conditions of weather this amount may possibly have to be modified a little, for it is well known that on hot sultry days milk will sour more quickly at a given temperature than on cooler days. The best rule to follow is to use enough of the mother starter to sour the milk in twenty-four hours at a temperature of $65^{\circ} \mathrm{F}$.

In the heating process all of the active bacteria in the skim-milk have been destroyed, thus leaving a clean field for the development of the lactic acid bacteria added to it from the bottle.

From what has been said it will be seen that the method of using the lactic acid bacteria is similar to the use of yeast germs in bread making. The original germs obtained in the way above described, or from the manufacturer, may be propagated for weeks by daily transferring a small amount of the thickened skim-milk to newly pasteurized skim-milk.

\section{COMMERCIAL STARTERS.}

Commercial starters usually consist of a single species of lactic acid organisms. These starters are prepared in laboratories where the utmost precautions are taken to keep them free from undesirable germs. The methods by which the good bacteria are separated from the bad are quite complicated and of too little practical value to permit a discussion of them here. Suffice it to say that such separation is possible only with the skilled bacteriologist. 
Preparation. Most of the commercial cultures are sent out in one-ounce bottles which are hermetically sealed. The method of making starters from them is the same for all whether they are obtained in the liquid or in the dry form.

In making the first batch of commercial starter, the entire contents of the bottle is put into a quart of skimmilk, sterilized by keeping it at a temperature of $200^{\circ}$ F. for two hours, and then cooling to $80^{\circ}$ which temperature should be maintained until the starter has thickened. A new starter is now prepared by introducing the quart of starter into about forty pounds of skim-milk, pasteurized by keeping it at a temperature of $170^{\circ}$ to $185^{\circ}$ for thirty minutes and then cooling to $65^{\circ} \mathrm{F}$. All subsequent starters are prepared in the same way except that the amount of mother starter for inoculation must be reduced a little for a few days because the germs become more vigorous after they have propagated several days.

The first and second starters prepared from a new culture seldom have the good flavor produced in subsequent starters. The cause of this in all probability is the inactive condition of the germs and the peculiar flavor of the medium in which they are sent out.

RENEWAL, OF STARTERS.

Under average farm conditions it is policy to renew the starter at least once a month by purchasing a new bottle of culture. It will be found that after the starter has been propagated for two or three weeks bad germs will begin to manifest themselves as a result of imperfect pasteurization, contamination from the air, or 
from overripening, so that its original good flavor may be seriously impaired at the end of one month's use. It is only where the utmost precautions are taken in pasteurizing the milk and ripening the starter, that it is possible to propagate a starter for many weeks and still maintain a good flavor.

\section{POINTERS ON STARTERS.}

I. Starters give best results when added to cream or milk immediately after they have thickened.

2. An overripe starter produces somewhat the same effect in butter as overripened cream. Curdy flavors are usually the result of such starters.

3. To prevent overripening, starter cans or starter vats must be used in which the temperature can be kept under perfect control.

4. Skim-milk furnishes the best medium for starters, since this has undergone the cleansing action of the separator and is free from fat, which hampers the growth of lactic acid bacteria.

5. Agitate and uncover the milk while heating to insure a uniform temperature and to permit undesirable odors to escape.

6. Always dip the thermometer in hot water before inserting it into pasteurized milk. The pasteurizing process becomes a delusion when dirty thermometers are used for observing temperatures.

7. Always use a sterilized can for making a new starter.

8. Keep the starter can loosely covered after the milk has been heated to prevent germs from thie air getting into it. 
9. Stir the starter occasionally the first five hours after inoculation to insure uniform ripening.

Io. Never disturb the starter after it has begun thickening until ready to use.

I I. When a new bottle of commercial culture is used, the first two starters from it should not be used in cream as the flavor is usually inferior on account of the slow growth of the bacteria and the undesirable flavor imparted by the medium in which the cultures are sent out. A commercial starter is usually at its best after it has been propagated a week.

I2. Always sterilize the neck of a new bottle of culture before emptying the contents into sterilized skim-milk. 


\section{CHAPTER XXIV.}

\section{SOF'T AND FANCY CHEESE MAKING.}

There is a rapidly growing demand everywhere for the soft varieties of cheese such as cottage, Neufchatel and cream, and the manufacture of this class of cheese is becoming a very remunerative branch of dairying. The soft varieties of cheese are deservedly becoming popular because of their wholesomeness and palatability.

\section{COT'TAGE CHEESE MAKING.}

Cottage cheese, which is made from skim-milk, may be manufactured in either of two ways, namely, with or without rennet extract. The cheese resulting from the use of rennet extract is finer grained though somewhat more acid than that obtained without rennet.

Rennet Method: When rennet extract is used, the night's separator skim-milk is held at a temperature of about 65 degrees $F$. until the following morning when it should show about 0.2 per cent acid. The temperature is then raised to 75 degrees $F$., and rennet extract added to the skim-milk at the rate of one-twentieth of an ounce (about one-half teaspoonful) per hundred pounds of milk. To insure an even distribution of the rennet, it should be diluted with a cup of water before mixing it with the milk. As soon as the rennet has been thoroughly mixed with the milk, the latter should be allowed 
to stand quietly at a temperature of about 70 to 75 degrees $\mathrm{F}$. for $2+$ hours, when a firm curd will have formed. The curd is now carefully dumped into a cotton bag or strainer and allowed to drain until all free moisture has escaped. Salt is next added at the rate of one and one-half ounces per ten pounds of cheese. The palatability of the cheese is much improved by adding a small amount of rich cream to it.

Fairly good results may be obtained by omitting the rennet.

Starter Method. This method yields the highest quality of cheese when fine flavored starter is used. Put the skim-milk into a vat and sour it with a good starter at a temperature of between 90 and 95 degrees $F$. The more starter used, up to 25 per cent, the better the quality of the cheese. Thoroughly mix the starter with the skim-milk and allow to remain undisturbed until firmly curdled. When this stage is reached, cut the curd, the same as in cheddar cheese making, and at once begin stirring by hand. Raise the temperature to IO4 degrees F., keeping the curd constantly stirred during the heating process. After this the curd should be stirred occasionally for about 40 minutes, when the whey may be drained off.

The draining is best accomplished in a tin strainer covered with a piece of cheesecloth. The curd must be hand-stirred as soon as it has been dumped into the strainer, but the stirring should be done very gently at the start to prevent loss by mashing the curd particles. Continue the stirring until the curd is firm enough to prevent the particles sticking together, which usually requires about five minutes. As soon as the curd has been 
stirred dry enough it is wrapped in the cloth strainer and squeezed with the hands until most of the free whey has been removed, that is, until it is dry enough to permit granulating it to fine particles by rubbing with the hands.

When the curd has been squeezed dry enough and thoroughly granulated by rubbing and stirring with the hands, it should be salted at the rate of about one and one-half ounces of salt per ten pounds of curd. After salting the curd is soaked with skim-milk or milk; or where a high quality of cheese is desired a thin cream should be used.

Packing Cottage Cheese. The same packages will answer for cheese made by either of the two methods. For simplicity and cheapness there is no better method of packing than the following: With an ordinary butter printer, print the cheese in one-pound blocks and then cut the blocks in two. This will make packages weighing onehalf pound each. The half-pound blocks are wrapped in thin parchment or oiled paper in a manner similar to wrapping one-pound butter prints. The sheets of parchment or oiled paper for this purpose should be six inches wide by ten and one-half inches long. Any dealer in dairy supplies can furnish this paper at a very small cost. If the cheese is to be sold in one pound packages the wrapping paper should be eight and one-half inches wide by ten and one-half inches long. Cottage cheese may also be packed in water-proof packages such as are used for carrying ice cream, oysters, etc. The fiber butter boxes, made of pasteboard and lined with parchment paper, will also be found satisfactory for this purpose. Both of the above styles of package should be lined with 
parchment paper before putting the cheese into them.

Some use wide-mouthed, single service milk bottles for packing cottage cheese.

Marketing. When much cheese is made, it should be marketed at fancy grocery stores and meat markets. If made on farms that operate daily milk routes in the city, much cheese can be sold on these routes to constmmers direct, thus saving the middleman's profits. The average retail price of the cheese is ten cents per pound.

The yield of cottage cheese, when made according to the methods herein described will approximate 15 pounds of cheese per Ioo pounds of skim-milk.

MAKING NEUFCHATEL, CHEESE.

There are two methods by which American Neufchatel cheese may be made, namely, with and without the use of starter. The method of making the cheese without starter is as follows: Place the night's milk preferably in shotgun cans and cool to a temperature as near 70 degrees F. as possible. Next add at the rate of about one teaspoonful of rennet extract for each hundred pounds of whole milk. The rennet should first be diluted in a cup of water and then thoroughly mixed with the milk. If the temperature of the milk is kept at 70 degrees $\mathrm{F}$. it will be thoroughly curdled in from $\mathrm{I} 5$ to 20 hours, when it should be perceptibly sour to the taste. The actual amount of acidity at this stage should be about 0.3 per cent. The curd is now poured onto a strainer rack covered with a cotton strainer cloth, or it may be poured or dipped into cotton bags, to drain. After the curd has drained an hour, light pressure should be applied to it which may be gradually increased to hasten the draining. 
As a rule, it is desirable to have the draining completed in about three hours, the temperature during this process being maintained at about 70 degrees F. Applying moderate pressure will hasten the draining and is recommended for best results. As soon as the curd has sufficiently drained, salt is added at the rate of one ounce to every five or six pounds of cheese. The cheese should be thoroughly kneaded with the hands to distribute the salt evenly and to give it a smooth consistency. It is now molded into cylindrical packages, $13 / 4 \times 23 / 4$ inches, weighing one-fourth of a pound. These cylindrical masses of cheese are first wrapped in thin parchment or oiled paper and then wrapped in tin foil. These packages usually retail at five cents each.

Starter Method. When starter is used a better flavored and more uniform cheese is possible. The starter may consist of well thickened whole milk allowed to sour in a natural way, but whole milk soured with pure culture of lactic acid bacteria is preferable. Where pure cultures are used the whole milk intended for starter should be pasteurized before inoculating it with the culture.

When starter is used the cheese is made as follows: Add at the rate of one pound of starter to four pounds of fresh whole milk. The mixture should have a temperature of about 80 degrees $F$. Next add at the rate of one-half tablespoonful of rennet extract per hundred pounds of milk, mixing the rennet with the milk as previously explained. When thoroughly curdled, which usually requires about one hour, the curd is ready to drain. The rest of the process is carried out the same as when no starter is used. 
Neufchatel cheese yields from 18 to 20 pounds per IOO pounds of milk.

CREAM CHEESE.

Cream cheese is made from milk containing about ten per cent butter fat; that is, milk reinforced with cream. Like Neufchatel cheese, this cheese may be made with and without starter, and the processes are the same as with Neufchatel cheese, except that it will be found advantageous to have the temperature from three to five degrees higher. Nuch butter fat is saved when making cream cheese by the starter method. Cream cheese is molded in rectangular forms, $11 / 4 \times 21 / 4 \times 23 / 4$ inches, holding about one-quarter of a pound. These packages usually retail at ten cents each.

\section{CLUB CHEESE.}

Another kind of cheese that is very much relished and that can be made by anyone, is known as "club" or "potted" cheese. The method of making this cheese is as follows: Grind up with an ordinary meat grinder five pounds of old, well-ripened checklar cheese of good flavor, and mix this with one pound of good butter. The mixing is casily accomplished with a bread mixer. The mixing should be continued until the cheese has a uniform consistency, free from lumps. Running the mixture through the grinder a second time and working it with the hands will assist in reducing the lumps. This cheese can be packed in small tin-top jelly tumblers, covering the top of the cheese with parchment paper. This makes an exceedingly palatable cheese which retails, as a rule, at forty cents a pound. The cheese may also be packed in the same manner as Neufchatel. 


\section{CHAPTER XXV.}

\section{COOLING AND AERATION OF MILK AND CREAM.}

Importance of Low 'Temperature. Milk always contains bacteria no matter how cleanly the conditions under which it is drawn. At ordinary temperatures these bacteria increase witi marvelous rapidity; at low temperatures their growth practically ceases. The effect of temperature on bacterial development is graphically shown in Fig. 57.
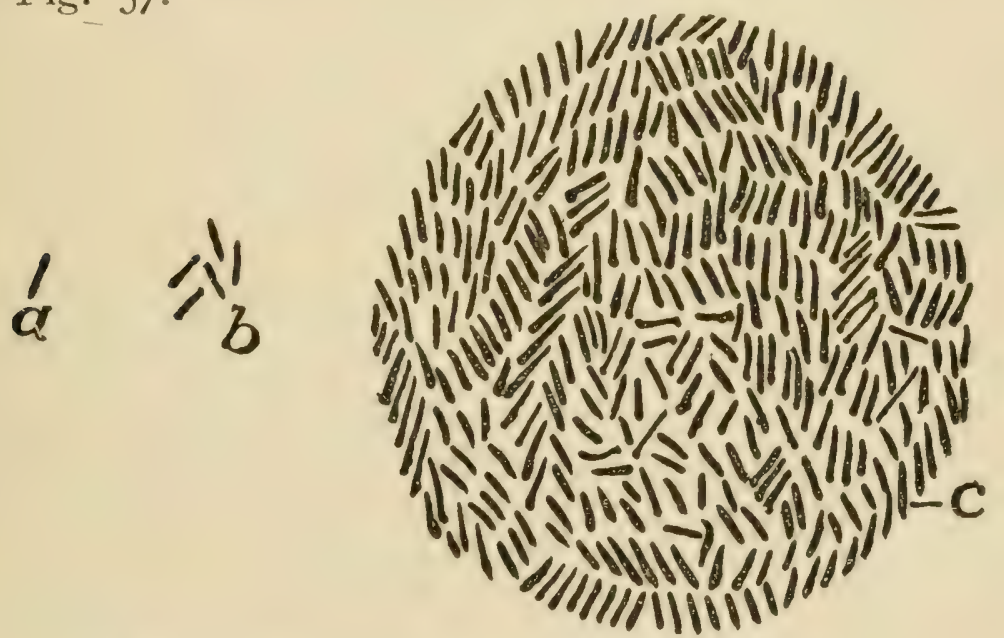

Fig. 57.-Relation of temperature to bacterial growth.

$a$ represents a single bacterium; $b$, its progeny in twenty-four hours in milk kept at $50^{\circ} \mathbf{F}$.; C , its progeny in twenty-four hours in milk kept at $70^{\circ} \mathbf{F}$. (Bul. 26, Storrs, Con11.)

At a temperature of $50^{\circ} \mathrm{F}$. the bacteria multiplied five times; at $70^{\circ} \mathrm{F}$. they nultiplied seven hundred and fifty times.

Roughly speaking, at $98^{\circ} \mathrm{F}$. bacteria multiply one hun- 
dred times faster than at $70^{\circ} \mathrm{F}$. At $32^{\circ} \mathrm{F}$. bacterial development practically ceases.

Milk or cream may be kept sweet a long time at $40^{\circ}$ to $45^{\circ} \mathrm{F}$. because the lactic acid bacteria practically stop growing at these temperatures. But there are other classes of bacteria that can grow at these temperatures, as evidenced by the production of undesirable flavors. Such flavors usually become noticeable after thirty-six hours. Where milk and cream are to be kept in the best possible condition, it is necessary to reduce the temperature to within a few degrees of freezing.

Lack of thorough cooling necessitates two deliveries of milk per day, and, what is still worse, requires many dairymen to milk their cows shortly after midnight and shortly after middlay, a drudgery which casts a damper upon the whole milk business. Lack of cooling also means financial loss through souring of milk and leads to many dissatisfied customers.

Prompt Cooling. Milk should be cooled as quickly as possible after it is drawn. Indeed, the milk should be taken directly from the cow to the cooling room and promptly cooled. To do this conveniently it is necessary to have the cooling room located as near the barn as is consistent with freedom from barn odors.

Too often the milk is allowed to remain in the barn until all the cows have been milked, and this may require from two to three hours, depending upon the number of cows milked by each milker. A few hours delay in cooling reduces the keeping quality of milk to a far greater extent than is commonly supposed.

Importance of Aeration. Milk not only contains bacteria immediately after it is drawn, but it also contains gases, chief among which, perhaps, is car- 
bonic acid gas. These gases should be removed as quickly as possible after milking by exposing the milk in thin sheets to the atmosphere. Fortunately the construction of modern coolers is such as to make it possible to do the cooling and aerating in one operation.

Formerly it was customary for dairymen to aerate their milk before cooling. Such practice is known to give somewhat better aeration than is possible where the cooling and aerating are performed in the same operation; yet the difference is so slight that consumers cannot detect it. The practice of aerating first and cooling afterward is therefore being abandoned.

Coolers. All modern coolers permit cooling with ice water. Without this a sufficiently low temperature cannot be obtained to stop practically all bacterial growth. To meet the requirements of dairies of different sizes, several styles of coolers are herewith described and illustrated.

Corrugated Cooler. This style of cooler is shown in Fig. 58, which also shows a desirable method of fastening it. It is especially adapted to dairies having from fifteen to thirty cows. The cooler consists of two parts: An upper section which is used to cool milk and cream with uniced water, and a lower section through which ice water is circulated.

A storage tank for well water may be placed above the ceiling. From this the water is admitted to the upper section through the valve which is used to regulate the flow. As shown by the arrows the water enters the section at the bottom and discharges at the top. The waste water may be conducted to the feed water tank of the boiler, to a watering trough, or other places where it may be useful. 


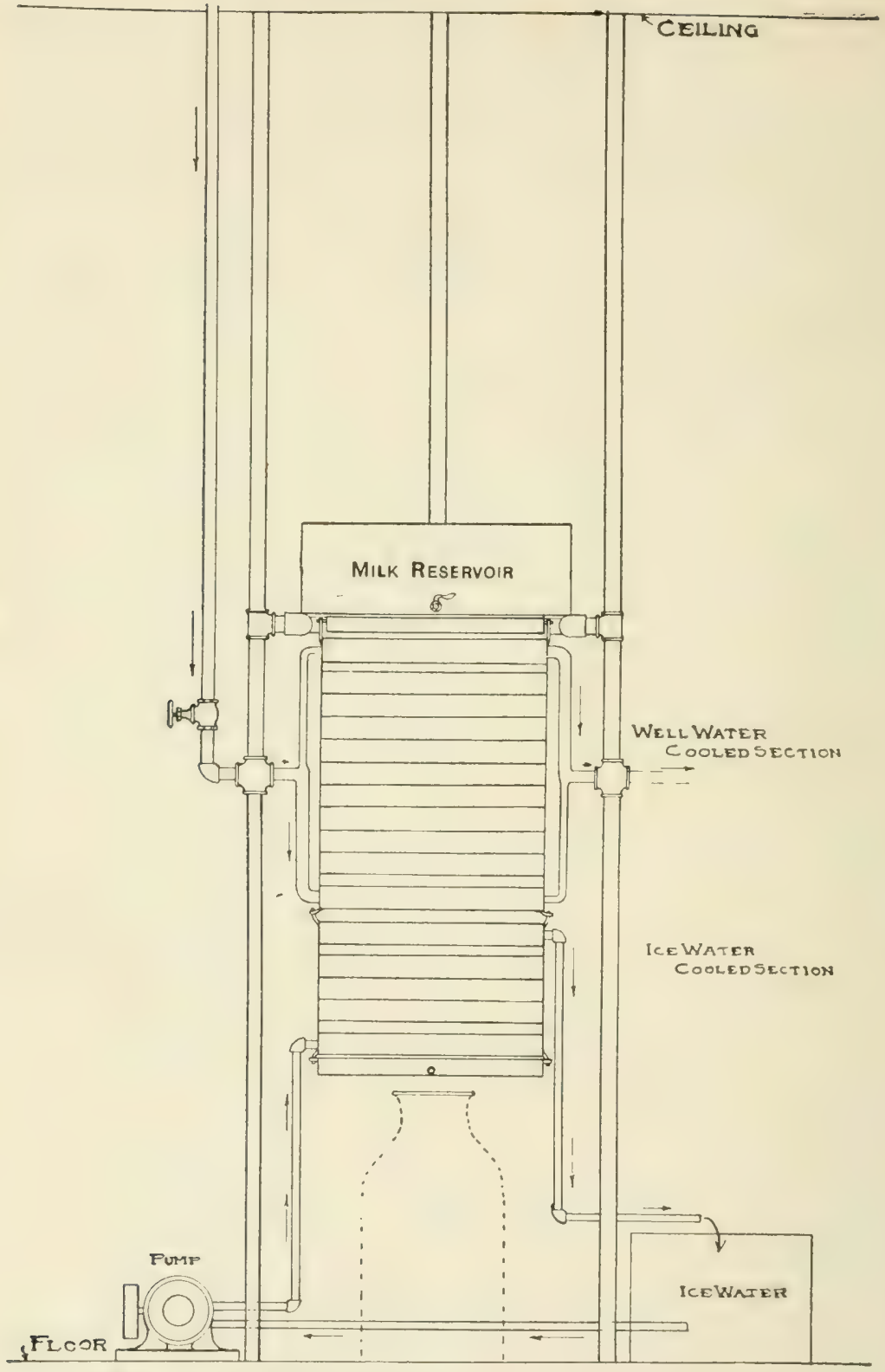

Fig. 58. - Showing Corrugated Cooler and Method of Support.

By means of the pump at the left, the ice water is forced back into the small tank at the right, which contains finely crushed ice. 
Cone=Shaped Cooler. For dairies having fewer than fifteen cows a cheap cooler like that shown in Fig. 59 may be used to advantage. The water enters the bottom of the cooler and discharges at the top, while the milk flows in a thin sheet over the outside. Ice may be placed

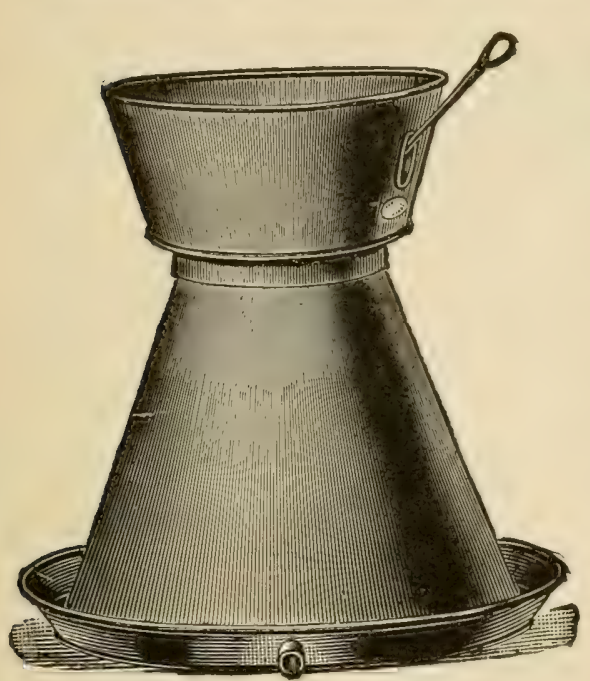

Fi g. 59.-Cone Shaped Cooler. inside the cooler, if desired. The can at the top is the milk receiver, which has small openings at the bottom near the outside, through which the milk discharges in fine streams, directly upon the cone below.

\section{Cooling Without Spe=} cial Coolers. When no special coolers are at hand milk and cream should be cooled in small cans by placing them in a tank or an oil barrel cut in two. Cold water is pumped into the tank or barrel in such a way that the cold water drops into the bottom of the tank, thus forcing out the warm surface water.

Water should be pumped into the tank at frequent intervals until the milk or cream has nearly reached the temperature of the water. The time of cooling is materially shortened by frequent stirring, which is a very essential part in cooling milk and cream in cans.

Where milk is placed in large cans and stirred little, farmers lose in having the test lowered by hard particles of cream forming at the top. Where milk is properly cooled, hard flakes of cream or churned cream will not be found on top of the milk. 
Precautions in Cooling. While cooling milk or cream, the room should be kept damp, especially the floor. This will keep down any dust that may be in the room and thus keep it from getting into the milk. Draughts should be avoided during cooling for the same reason. In this connection it is well to remember that the real harm is not so much in the dust particles themselves as in the many bacteria which usually adhere to them.

Where coolers are left exposed to the air of the room after they have been cleaned and sterilized, they should be rinsed off with boiling water just before using.

It is important also to use a reliable thermometer. Ordinary cheap thermometers often read two to six degrees too high or too low. A standard thermometer should be on hand, by which the cheaper ones may be standardized.

Never Use Ice in Milk or Cream. Adding ice directly to milk and cream is a pernicious, though not uncommon, practice. The best of natural ice contains dirt and bacteria. Even ice made by mechanical means from distilled water often contains considerable quantities of impurities. Ice also is an adulterant just as much as water. In case of cream cooled with ice the body is unsatisfactory, even if the cream contains the required amount of fat.

COLD STORAGE.

Cold storage of some kind is indispensable to a well equipped dairy. Many, however, lack this essential, either bcause they do not appreciate its importance, or 
because of the rather high price of commercial refrigerators.

The construction of this box, shown in Fig. 6o, con-

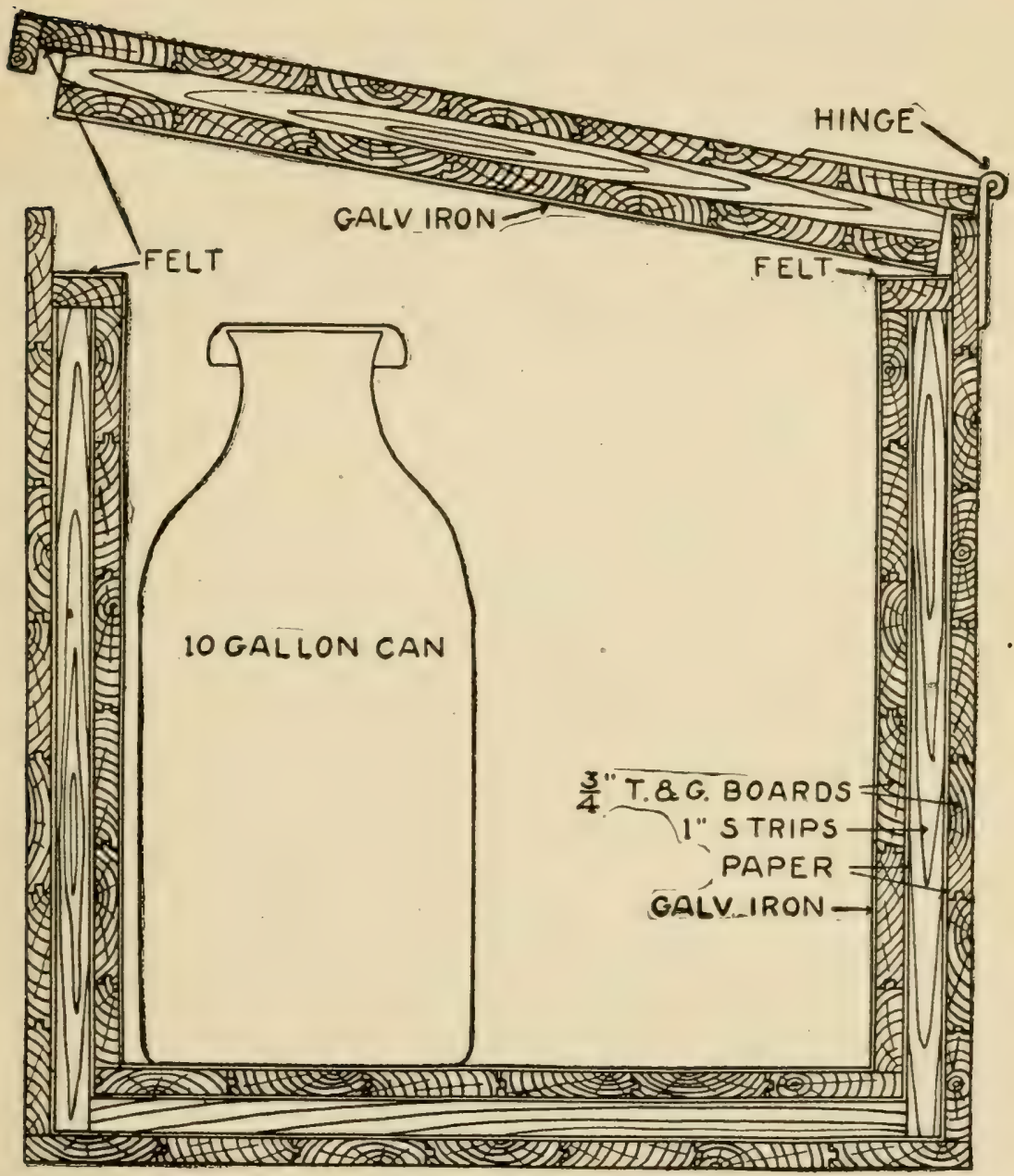

Fig. 60.-Cross-Section of Cheap Ice Box.

sists essentially of two boxes separated by one-inch strips placed at intervals of about one foot. Double thickness of building paper is placed on both sides of the strips 
and tacked to the boxes. A one-inch strip, two inches wide, covers the upper space between the one-inch strips, thus making a dead-air space between the two boxes. The construction of the cover is the same as that of the bottom, with the exception that there is a flange at the front and sides of the cover. The sides, bottom and cover of the refrigerator are built of three-quarter-inch tongued and grooved lumber, five and a half inches wide. The ends are constructed of one and one-eighth inch tongued and grooved flooring three and a half inches wide. The inside of the ice box is lined with galvanized iron. 


\section{CHAPTER XXVI.}

\section{HOW TO SECURE A GOOD MARKE'T.}

Quality. As a rule it is easy enough to secure some kind of a market, but to secure the best frequently requires considerable effort. To get fancy prices requires first of all that the product be of superior quality. This is particularly true of milk. The extensive agitation in recent years for clean, pure milk has had the effect of putting a high premium upon such milk. The public is becoming aware of the dangers which lurk in dirty, unsanitary milk and is willing to pay a good price for milk whose wholesomeness is unquestioned.

Value of Advertising : To obtain big prices it is not enough to have products of superior quality, but whatever particular merits they have must be forcibly brought to the attention of consumers. In other words, a certain amount of advertising is necessary.

It is good policy to furnish prospective customers a . few free samples and to distribute leaflets describing the conditions under which the products are produced and handled. If the milk is produced in clean, ventilated, whitewashed stables, and from cows which are regularly tested for tuberculosis; if the milk is handled by clean, healthy attendants and is thoroughly cooled and aerated immediately after milking; and if, in addition, all this is certified to by a competent inspector, an increase in prices and patronage is certain to follow when such facts are placed before the public. 
The majority of city consumers have little conception of the conditions under which average milk is produced. For this reason the man who is producing clean milk will find it highly profitable to place in contrast vivid pictures of the conditions that yield average milk and those that yield sanitary milk.

Investigate Outside Markets. Often outside markets offer better prices for milk and cream than does the home market. This is especially true of cream. This product permits of long distance shipping and many outside markets may be glad to get it at fancy prices when the home market may be entirely overstocked.

Dairymen must not expect the market to come to them, however; they must seek the market. A visit or correspondence with managers of cafés, hotels, restaurants, drug stores and ice cream manufactories in different cities, is frequently the means of securing more business and better prices.

Where one is just starting in the dairy business or trying new markets, it is good policy, as a rule, not to ask very high prices at the start. First demonstrate the merits of your products. If these are of a high order consumers will gradually respond to demands for increased prices rather than lose the products. Too high prices at the start are likely to discourage prospective buyers, and thus deprive you of an opportunity to prove the value of your goods.

Uniformity: One of the essentials in building up a good market is uniformity of product. Where this is lacking, improvements in other directions will be of little avail. On the other hand, products which are uniformly the same, week after week, and month after month, are 
likely to command good prices even when of only medium quality.

Punctuality. Another essential in building up a good market is punctuality. If your customer expects his milk at $7: 30$, do not deliver it at $7: 40$; deliver early rather than late. If you are shipping cream or milk you cannot afford to miss your train-even a single time. It generally means greater disappointment at the other end of the line than one would anticipate.

Try to Please. Always put yourself in an attitude to please. If criticisms come concerning your products, you cannot afford to resent them. Usually there is reason for the criticism. Try to discover the trouble and remedy it.

Delivery Outfit. Cleanliness and neatness must characterize the dairy business throughout. Milk wagons, cans, bottles, drivers, etc., must present a clean appearance. Where they do not, it is usually an easy matter to surmise the condition of milk.

Use a Trade Mark: The name or monogram of the dairy, placed upon the products and delivery wagons, guarantees genuineness and will materially assist in securing a better and more extended market. It is one of the best ways of advertising a superior product.

Secure Your Market Early. If it is intended to sell cream for manufacture into ice cream, it is important to get a market early in the spring. It is difficult to find one in the flush of the ice cream season, because ice cream dealers, as a rule, contract considerably in advance of the time they need the cream. If it is intended to supply winter resorts, apply for the market early in the fall. What has been said here with reference to cream applies also to milk. 
Secure Reliable Customers. Where milli and cream are shipped some distance, it is important to determine beforehand the reliability of the buyer. As a rule it is good policy not to make more than three shipments before the first has been paid for. It is well, even where milk and cream are sold locally, to investigate the standings of customers before their accounts have run up very high.

Selling Direct to Consumers. No argument is needed to show the advantage of selling dairy products direct to consumers wherever this is possible. It means the elimination of the middleman whose profits are saved to the dairyman.

Letterhead Stationery. It is not only businesslike to use stationery with a suitable letterhead, but it also serves to advertise the business. The following is submitted as a suitable form of letterhead:

Springdale Sanitary Dairy.

J. C. Boone, I'rop.

Dealer in

Pure, Bottled, Jersey Milk and Cream

from Tuberculin Tested Cows.

Reidsville, N. H............ I90.. 


\section{CHAPTER XXVII. \\ MARKE'IING MILK AND CREAM \\ RE'I'AILING.}

Dip Method. The old method of hauling milk to the city in five, eight or ten gallon cans and removing each patron's allowance by means of a dipper or faucet, has been found so oljectionable that the practice has been largely abandoned. The principal objections to this method are: (I) The admission of dust and bacteria to the milk while measuring it; (2) the use of unsterilized milk vessels by consumers; (3) exposure of the vessels to dust while on the steps of the consumer; (4) the use of unclean vessels by milkmen in measuring each customer's share; (5) lack of uniformity in the milk, especially if removed from the cans by means of a faucet, in which case the first drawn milk is likely to be lowest in fat content; and (6) the possibility of drivers tampering with the milk.

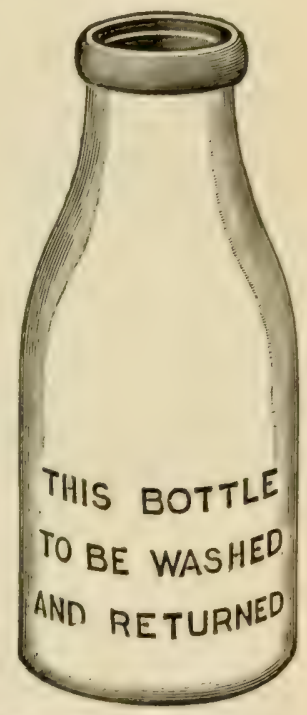

Fig. 61.-Milk Bottle.

The Use of Bottles. Milk and cream intended for retail trade should be put into pint or quart bottles, like that shown in Fig. (II. The advantages of this method are apparent from the fact that the milk is bottled immediately after cooling and that it may be 
kept in the same bottle until it is to be consumed. Whenever milk is changed from one vessel to another there is always more or less contamination from dust and bacteria.

Bottling: For dairies having from ten to twenty cows, a can or vat provided with a sanitary faucet will do satisfactory work in filling bottles. A pouring can with a slightly curved spout may also be used for this purpose.

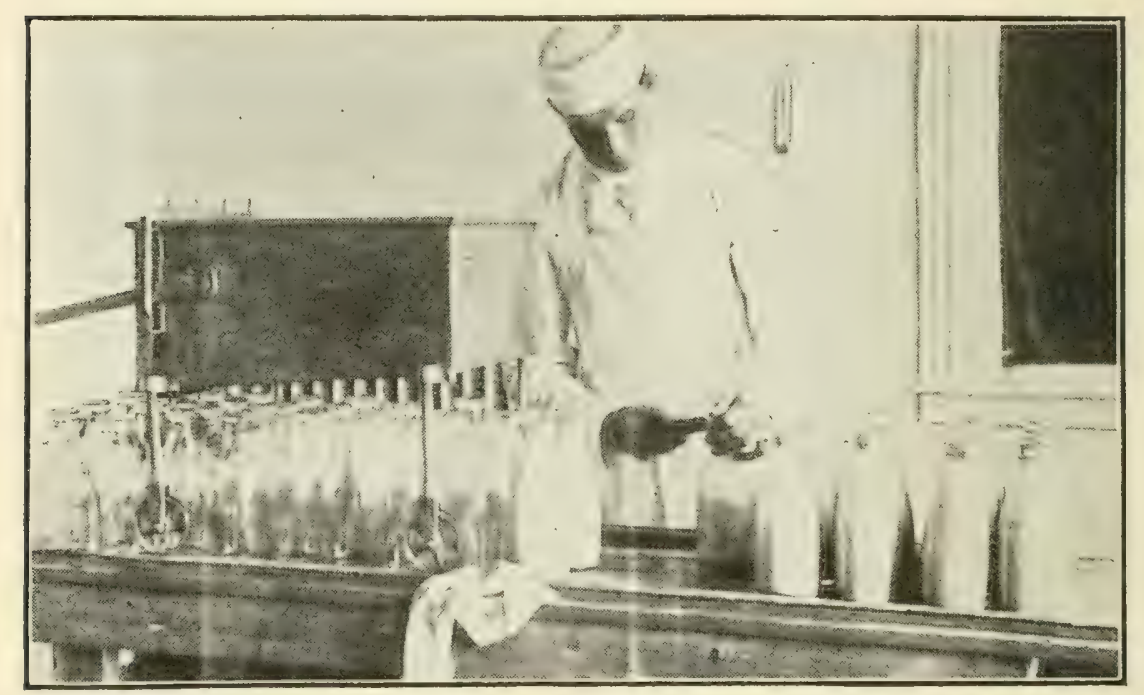

Fig. 62. -Filling Bottles with Machine. (From Da. Div., U. S. Dept. of A.)

For large dairies a bottle filler like that shown in Fig. 62 will be found advantageous. This machine fills six bottles at the same time. Larger or smaller fillers may be had if desired. In selecting a bottle filler secure one of simplest construction and preferably without rubber attachments. This is important for sanitary reasons.

Whatever method of filling is used, it is important to keep the milk well stirred while filling, so as to insure uniform quality in all the bottles. 
Immediately after filling, the bottles should be capped with paraffined caps made for this purpose. Fig. 63 illustrates a cap provided with a little handle which facilitates its removal and leaves it intact.

During bottling the room should be kept damp to keep the air free from dust and bacteria. No air current should be allowed to sweep in from the outside. Only clean laundered white suits should be worn by those in charge of the cooling and bottling.

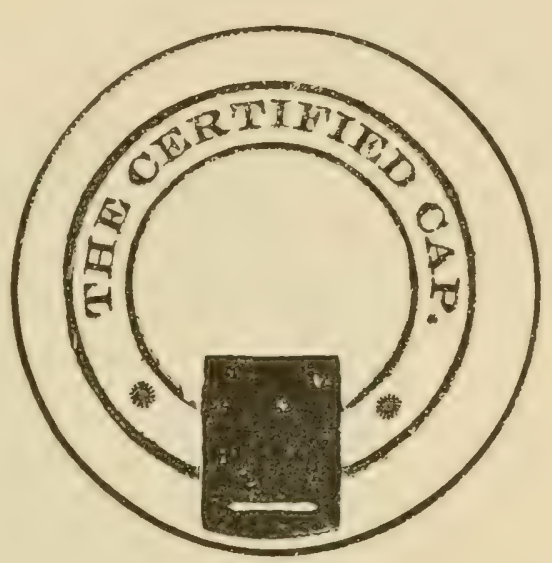

Fig. 63. Bottle Cap with Handle.

Milk Bottle Delivery Cases. On delivery wagons the bottles are carried in cases holding twelve or more

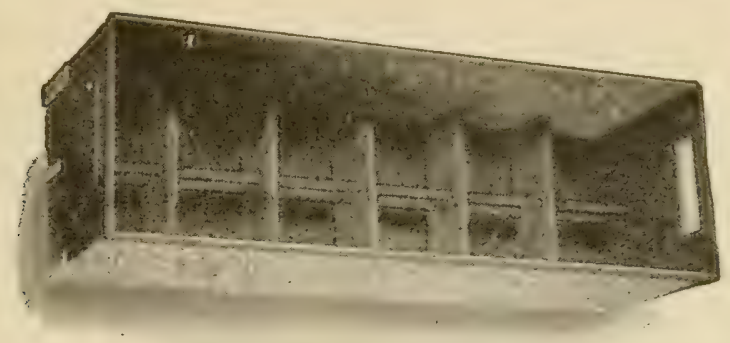

Fig. 61.-Galvanized Iron Milk Bottle Case.

bottles each. These cases are made of galvanized iron or wood, or of both, and have light removalsle partitions inside, separating the bottles to keep them from breaking. Galvanized iron cases, like that shown in Fig. 64, are 
the most sanitary and also permit putting crushed ice around the bottles.

Fig. 65 shows a galvanized iron milk bottle case, enclosed by a box made of one-inch boards and provided with a tight fitting cover. Cases of this kind should be used in warm weather to keep the milk cool during

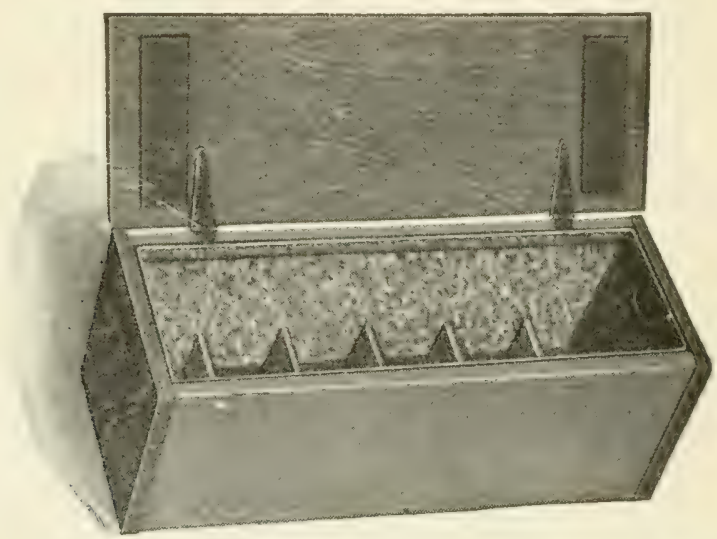

Fig. 65.-Insulated Galvanized Iron Milk Bottle Case.

delivery. On especially warm days, crushed ice should be used around the bottles. This style of case is also recommended where bottles are shipped.

A great deal of milk is spoiled while in transit to the consumer. The last milk delivered on the route may be on the road five or six hours before it finally reaches its destination. If carried in open, uniced cases, on warm days, an exposure of such duration may easily shorten the keeping quality of the milk by eight or more hours.

A matter of prime importance in delivering milk in bottles is to have them thoroughly sterilized before using. Unless this is done milk will not keep long and, what is worse, is likely to disseminate disease along the route. 
This danger is due to the bottles' passing from one home to another and eventually reaching a home in which there is some cantagious disease. Ir. such cases there is always a probability that the bottles may become infected with the disease germs.

Frequency of Delivering Milk. When milk is cooled to $45^{\circ} \mathrm{F}$ : or below immediately after milking and is held at this temperature until it reaches the consumer, one delivery a day is sufficient. If it is desirable, however, to make two deliveries a day, these should be made independent of the milking; that is, the night's milk should be delivered in the morning and the morning's milk in the afternoon.

In some sections, especially in the south, milk is sold with little or no cooling whatever. Hence, the practice of delivering the morning's milk before breakfast, and the night's milk before supper. 'This practice requires the first milking to be done shortly after midnight and the second milking shortly after midday, a drudgery wholly unnecessary and easily obviated by thoroughly cooling the milk.

Delivery Wagons. These should be clean, covered, well painted, and provided with good springs. The name of the dairy should be printed on each side. A neat and attractive delivery wagon is essential in building up a good trade.

\section{STANDARDIZING MILK AND CREAM.}

This is a process by which milk and cream are brought to a definite percentage of fat. Cream producers are called upon to furnish cream of a definite richness, and different grades may be demanded by different buyers. The simplest way to meet such demands is to have the separator deliver cream somewhat richer than the richest grade called for and to reduce this to the required richness by adding skim-milk. 
Reducing Cream with Skim=milk. Then a definite quantity of standardized cream is called for, determine first the amount of original cream (cream as it leaves the separator) required according to the following rule:

Rule: Niultiply the number of pounds of standardized cream called for by its test and divide the product by the test of the original cream.

The difference between the amounts of original and standlardized cream represents the amount of skim-milk required.

Problem: How many pounds each of $45 \%$ cream and skim-milk (zero test) are required to make 60 pounds of $18 \%$ cream?

Applying the above rule we get,

$(60 \times 18) \div 45=24=$ No. 1bs. of original cream.

$60-24=36=$ No. 1bs. of skim-milk.

Milk may be standardized in the same way.

Mixing Two Milks or Two Creams, or Milk and Cream, of Different Richness. In the preceding two formulas the test of the skim-milk was considered zero. When milks or creams of different tests are mixed the calculation becomes more difficult. Pearson, however, has devised a method by which calculations of this kind are very much simplified. This method is as follows:

Draw a rectangle with two diagonals, as shown below. At the left hand corners place the tests of the milks or creams to be mixed. In the center place the richness 
desired. At the right hand corners place the differences between the two numbers in line with these corners. The number at the upper right hand corner represents the number of pounds of milk or cream to use with the richness indicated in the upper left hand corner. Likewise the number at the lower right hand corner represents the number of pounds of milk or cream to use, with the richness indicated in the lower left hand corner.

Example: How many pounds each of $30 \%$ cream and $3.5 \%$ milk required to make $25 \%$ cream?

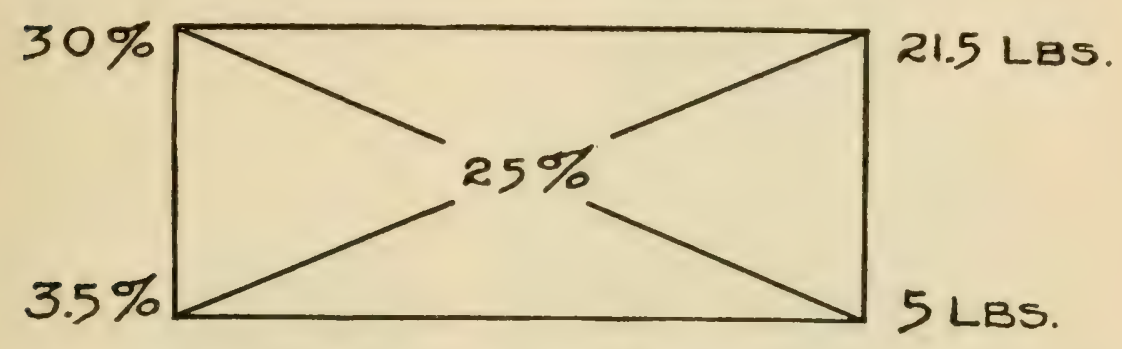

21.5 , the difference between 3.5 and 25 , is the number of pounds of $30 \%$ cream needed; and 5 , the difference between 25 and 30 , is the number of pounds of $3.5 \%$ milk needed.

From the ratio of milk and cream thus found, any definite quantity is easily made up. If, for example, 300 pounds of $25 \%$ cream is desired, the number of pounds each of $30 \%$ cream and $3.5 \%$ milk is determined as follows:

$$
\begin{aligned}
& \begin{array}{l}
2 \mathrm{I} .5+5=26.5 \\
\frac{2 \mathrm{I} .5}{26.5} \times 300=243.4, \text { the number of pounds } \\
\text { of } 30 \% \text { cream. }
\end{array} \\
& \begin{array}{r}
\frac{5}{26.5} \times 300=56.6, \text { the number of pounds } \\
\text { of } 3.5 \% \text { milk. }
\end{array}
\end{aligned}
$$


The essential things in shipping milk and cream are cleanliness and low temperature. It is possible to keep milk and cream in good condition for two or three days, if produced and handled under cleanly conditions and

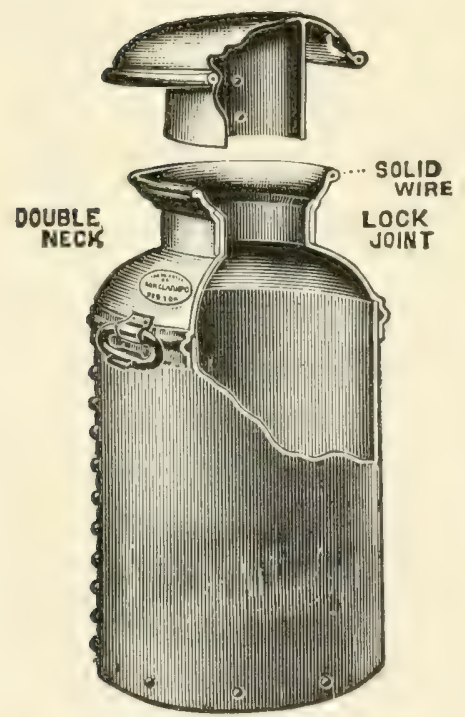

Fig. 66.-Milk Can.

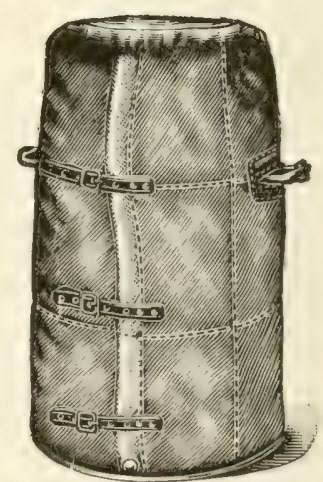

Fig. 67.-Felt Jacket on Can.

cooled directly after milking to $40^{\circ} \mathrm{F}$. or below. This low temperature must be maintained when long keeping quality is desired. Every dairy should be provided with a good ice box or refrigerator, into which milk and cream 
may be placed immediately after cooling and in which they may be kept until ready for shipment.

Shipping in Cans. Tarious insulated cans are now upon the market and a number of these have been tested by the author. 'The tests showed that these cans possess about the same insulating effect as the felt jackets that are commonly wrapped around ordinary milk cans. Since the latter, as a rule, are more durable and more easily handled, they will be found more satisfactory when wrapped with a felt jacket than the socalled insulated shipping cans.

When milk and cream are cooled close to freezing and placed in ordinary milk cans wrapped in felt jackets, they may be safely shipped to any point that may be reached within 24 hours even in warm weather.

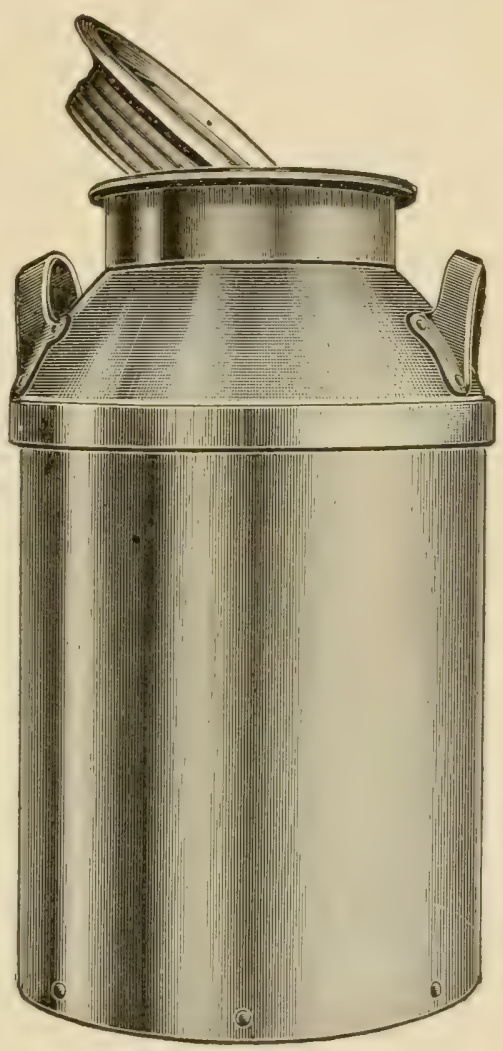

Fig. 68.-Screw Top Can.

If the temperature of the milk and cream at the time of shipment is $50^{\circ} \mathrm{F}$. or higher, then long distance shipment is best accomplished by the use of an ordinary can placed inside of a covered ice cream shipping tub containing ice. Such a tub has practically the same in- 
sulating effect as a felt jacket, but is rather heavy and cumbersome and should not be used except in cases where it is necessary to pack ice around the cream or milk. The best results from the ice are secured by packing it in large lumps around the neck of the can.

Shipping in Bottles. Where milk and cream are shipped in bottles, the latter should be placed in insulated delivery cases (Fig. 65) and surrounded with crushed ice. The cases should have the owner's address on them and must be kept locked while in transit.

Mode of Shipping: The usual way of shipping milk and cream is by express. In the main dairy sections baggage rates are available. These rates are lower than express rates and can be obtained nearly everywhere by special arrangement with the railroad companies.

Shipping rates should always be obtained in advance of shipment and the charges should be prepaid. A considerable saving is certain to be effected by rigidly adhering to this practice. Insist upon getting the lowest rates possible.

Pointers on Shipping. Have the name and address of your dairy permanently marked in brass upon every can and cover; also have it sewed or stitched on the felt jackets. This is necessary to insure the return of your own goods. The name and address will be put upon the cans and covers by the dealer from whom they are purchased, if so requested; or, in case unmarked cans are already on the premises, the brass plates with the name and address may be purchased from dairy supply firms and placed upon the cans and covers by a local tinner.

Even when labeled as indicated above, cans will occasionally get lost. Empty cans are usually returned free of charge and, for this reason, express receipts are com- 
monly not taken for them. This is a mistake. If the purchaser of your products will take a receipt for the cmpty cans, th_ express company becomes responsible for them in the event they are lost. Without the receipt it is next to impossible to claim damages for lost goods.

The empty cans should be washed before they are returned. This should be done for sanitary reasons as well as for the protection of the cans, which are short-lived unless washed and dried immediately after use.

Another matter of importance in shipping is to have the cans full to prevent churning.

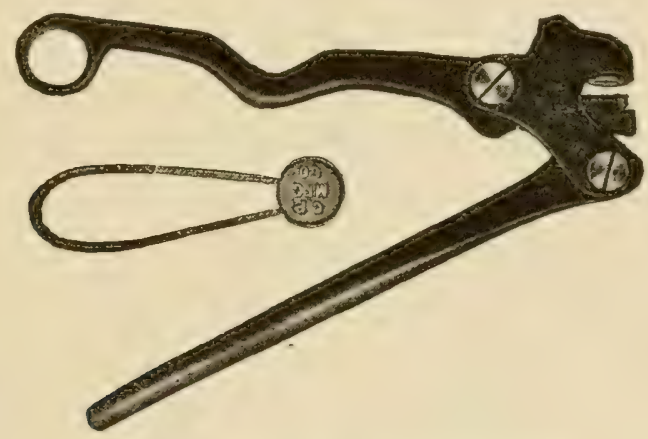

Fig. 69.-Lead Seal and Seal Press.

It is necessary also to have the cans sealed to prevent tampering with the contents. The sealing is easily accomplished by means of lead seals and a seal press (Fig. 69).

In delivering the cream or milk at the station the delivery man should see to it that the cans are put in as cool a place as possible. 


\section{CHAPTER XXVIII.}

ICE CREAM MAKING.

Kind of Cream. Select the best flavored sweet cream containing about $20 \%$ butter fat. To secure the best bodied ice cream and the proper swell, cream should be kept as near the freezing point as possible for twentyfour hours previous to freezing.

Freezing Process. With an initial temperature of about $35^{\circ} \mathrm{F}$., the time required to freeze ice cream should average about twelve minutes, and to get the best consistency the temperature at the close of the freezing process should be approximately $28^{\circ} \mathrm{F}$.

Too quick freezing causes the water to separate from the cream, which results in a granular ice cream. Freezing too slowly reduces the overrun and tends to make the ice cream smeary.

To reduce the temperature of a mass of cream below the freezing point, requires a freezing mixture of a low temperature. Such a mixture is secured by mixing salt and crushed ice in the proportion of one of salt to about six to twelve of ice. The purpose of the salt is to lower the freezing point of the melting ice and to hasten the melting.

To melt one pound of ice at $32^{\circ} \mathrm{F}$. into water at the same temperature requires 142 heat units. Rapidly melting ice, therefore, absorbs a large quantity of heat which 
in the freezing of cream is largely extracted from the cream.

The temperature of the ice cream mixture when starting the freezer should be as near freezing as possible to prevent churning the cream. The tendency to churn is also lessened by revolving the freezer slowly the first few minutes in freezing.

In packing the freezing mixture around the cream container, fill the freezer about half full of finely crushed ice and finish the filling by using salt and ice in the proportion of about one to three. As the ice mixture works down during the freezing process, continue adding more salt and ice as needed.

If the freezer is started while the cream is still warm (about $60^{\circ} \mathrm{F}$.), the speed of the freezer must be kept down until a temperature of about $35^{\circ} \mathrm{F}$. is reached. After this the speed is increased to 150 to 200 revolutions per minute until the cream is frozen. This speed insures the proper incorporation of air and the desirable smoothness of the finished product.

The freezer should be stopped before the cream becomes too thick, else it will lose some of the air that has been incorporated as well as show a tendency to coarseness in texture. Yield and quality therefore demand that the freezer be stopped while the cream is still a trifle soft.

Vanilla Ice Cream. To make three gallons of finished ice cream, requires about two gallons of cream to which should be added about three pounds of sugar, or one and one-half pounds to the gallon. The sugar should be well mixed with the cream and allowed to dissolve before starting the freezer. Next add at the rate of about twothirds ounce of vanilla extract and freeze. 
Chocolate Ice Cream. This can be made by adding chocolate flavor to finished vanilla ice cream.

Where a regular batch of chocolate ice cream is made, the chocolate is added before starting to freeze.

Lemon Ice Cream. In making lemon flavored ice cream, use the best paper-wrapped lemons, free from any signs of decay. Wash the lemons lightly in cold water and grate off the outer, yellowish portion of the rind, being careful not to grate off any of the white portion which is very bitter. Mix the grated rind with sugar, using one ounce of sugar for each lemon rind. Next cut the lemons in two and squeeze out the juice, removing any seeds that may have dropped in from the squeezer. Mix the juice with the sugared rind and add orange juice to the mixture, using one orange to every three or four lemons. Allow the mixture to stand for about one hour, stirring it occasionally, and then strain. Use at the rate of one-half pint per gallon of cream. The flavor is adcled to the cream when nearly frozen to prevent curdling it. Use two pounds of sugar per gallon of cream.

Walnut Ice Cream. L'se two gallons of cream, three pounds of sugar, one and one-third ounces vanilla extract and one and one-third pounds of ground walnut meats. Freeze the same as vanilla ice cream.

Other Nut Ice Creams. Chestnut, filbert, hazelnut, pecan, peanut and almond ice creams may be prepared essentially as walnut ice cream.

Strawberry Ice Cream. Use two gallons of cream, three pounds of sugar and two-thirds quart of crushed strawberries. The fruit should be added to the cream after it is partially frozen so as not to curdle the cream or to have the fruit settle to the bottom. 
Other Fruit Ice Creams. Cherry, raspberry, pineapple, peach, apricot, currant, grape and cranberry ice creams are made the same as strawberry, except that the amount of sugar is varied according to the acidity of the fruit.

Packing Ice Cream. Remove the ice cream from the freezer while still in rather soft condition and put the same in packing cans which have been thoroughly chilled by having the ice and salt packed around them about ten minutes before receiving the ice cream. Most of the salt should be put near the top, the same as in freezing. The ice cream should be held in the packing cans at a temperature below $20^{\circ} \mathrm{F}$.

Remove the brine and repack often enough to prevent melting. In the melting process the water separates and forms undesirable crystals when the cream is refrozen. Always repack with a new freezing mixture just before the ice cream leaves the dairy:

The Overrun or Swell. This refers to the excess of ice cream over cream. Anything that tends to incorporate and hold air in cream conduces to a large overrun. Thus excessive beating of the cream during freezing mixes a great deal of air with it, and hence, increases the overrun. A high viscosity of the cream holds the air incorporated during freezing. Fresh separator cream has a low viscosity, that is, does not whip well, hence will not swell up so much in freezing as cream that has been kept cold for twenty-four hours. Pasteurized cream also has a low viscosity, but this will improve by keeping the cream at a low temperature a number of hours before freezing.

An overrun of from 50 to 60 per cent is large enough. 
Overruns approximating 80 to 90 per cent are obtained at the expense of quality.

Marketing Ice Cream. Hardly any attempt has yet been made by cream producers living within driving distance of cities to convert their cream into ice cream and sell this product direct to consumers. This is somewhat surprising, since the largest profits in the cream business have hitherto been made by what may be called the middleman, the city ice cream manufacturer.

It is a vital matter with producers to reach consumers direct wherever this is possible, and thus save the middleman's profits. With those who retail milk and cream, the marketing of ice cream would entail no extra expense.

The essential thing in building up a good ice cream trade is to make the best product possible. The market is glutted with cheap, inferior ice cream, and the call now is for a high grade product. Fortunately the public is beginning to realize that there is positive danger in eating ice cream made from old, stale milk or cream. and the public also seems to begin to understand that the bulk of ice cream is made with so-called thickeners, like gelatine, corn starch, tapioca, arrow root, and others. Many so-called ice creams contain no cream whatever. The highest quality of ice cream contains nothing but good, pure cream, sugar and flavoring. 


\section{CHAPTER XXIX.}

MAKING AND MARKETING SKIMMILK-BUTTERMILK.

Souring the Skim=milk. As soon as the skim-milk leaves the separator, whole milk is added at the rate of one gallon to twenty gallons of skim-milk. This gives the mixture a fat content, which approximates that of ordinary buttermilk. A large quantity of pure culture of lactic acid bacteria (starter, see p. I9.3) is next added and the temperature brought to $70^{\circ} \mathrm{F}$. Enough starter is added to curdle the skim-milk in about six hours at the temperature mentioned. This requires about one pound of culture for every three pounds of skim-milk. When a temperature above $70^{\circ} \mathrm{F}$. is employed, there is a tendency for whey to separate after the skim-milk has curdled.

Churning. When thoroughly curdled, the skim-milk is placed in a churn and churned for about thirty minutes in the same way that cream is churned in making butter. The churning process thoroughly breaks up the curd clots, resulting in a smooth, thick liquid which cannot be distinguished from ordinary good buttermilk.

Cooling. Immediately after the buttermilk leaves the churn, the temperature should be reduced below $50^{\circ} \mathrm{F}$. to prevent further development of acid and the separation of the whey. Ordinary milk and cream coolers with enlarged holes in the distributing receptacle will answer very satisfactorily.

Straining. As soon as cooled, the buttermilk should 
be run through a strainer consisting of one thickness of cheese cloth to remove any untroken curd clots.

Bottling. After it is strained the buttermilk is bottled or put in tin cans holding from one to five gallons, after which it is placed in the refrigerator where it is held until ready for delivery.

Marketing Skim=milk Buttermilk. In trying to sell skimmilk-buttermilk it is necessary in the first place, to explain that this product, when made as herein described, is almost identical with the highest grade of natural buttermilk, both in composition and physical properties, and, therefore, in palatability and wholesomeness. Indeed, it is not thought possible under average conditions to secure natural buttermilk of as uniform a quality or as fine a flavor as can be obtained from skim-milk. When these facts are explained to dealers and consumers, any prejudices which might exist against this so-called artificial product are certain to vanish.

The dealers in buttermilk should be furnished with attractive signs, calling attention to the fact that the product is for sale by them. Buttermilk is not found at all soda fountains, and unless conspicuous signs are posted at these places, the public may not call for it.

Buttermilk may readily be sold to drug stores, restaurants, hotels and boarding houses at from ten to thirty cents per gallon, averaging about twelve cents per gallon.

As with cottage cheese, the most satisfactory way of disposing of buttermilk is to sell it direct to the milk and cream customers along the dairy route.

Where buttermilk is intended to be used as a beverage, it is important to keep its temperature below $50^{\circ} \mathrm{F}$. until it is consumed.

Food Value of Buttermilk. When used as a bever- 
age, buttermilk is usually appreciated only for its palatability. Aside from this, however, it has a high dietetic, as well as high medicinal, value. In certain diseases, especially those affecting the alimentary tract, buttermilk is considered indispensable. Its nutritive value is high, two quarts being approximately equal to one pound of good beefsteak.

Buttermilk From Pasteurized Skim=milk. The best buttermilk is obtained by adding the starter to pasteurized skim-milk. Under such conditions the entire skim-millbecomes virtually a starter or pure culture of lactic acid bacteria. This not only means a better flavor but also insures freedom from pathogenic organisms. Pasteurization also lessens the tendency for the whey to separate. 


\section{CHAPTER XXX.}

CER'TIFIED MILK.

Definition. Certified milk is milk produced under conditions imposed by medical milk commissions, which ustrally employ a veterinarian, a bacteriologist and a chemist to look after the production of the milk. It must

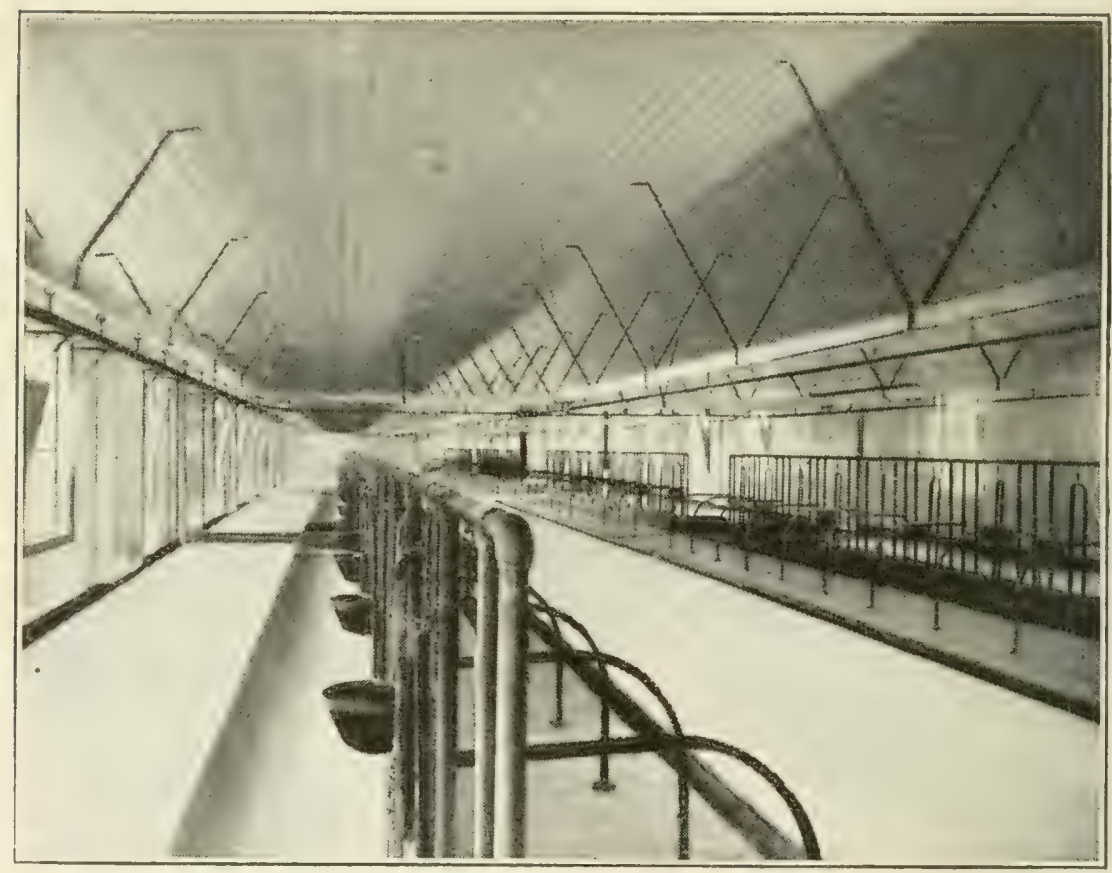

Fig. 70. -Sanitary Dairy Barn. (Da. Div., U. S. Dept. of A.)

be free from disease germs and preservatives, must have a known chemical composition, and must be so produced and handled as to insure a minimum number of bacteria. 
If the producer has complied with all the requirements he is furnished a certificate by the commission, which permits him to use the "certified" label on his products.

The term "certified milk" is registered in the United States patent office and its use is legally permitted only on milk approved by medical milk commissions.

Uses. Certified milk is now largely used for infants and invalids. There is, however, also a rapidly increasing

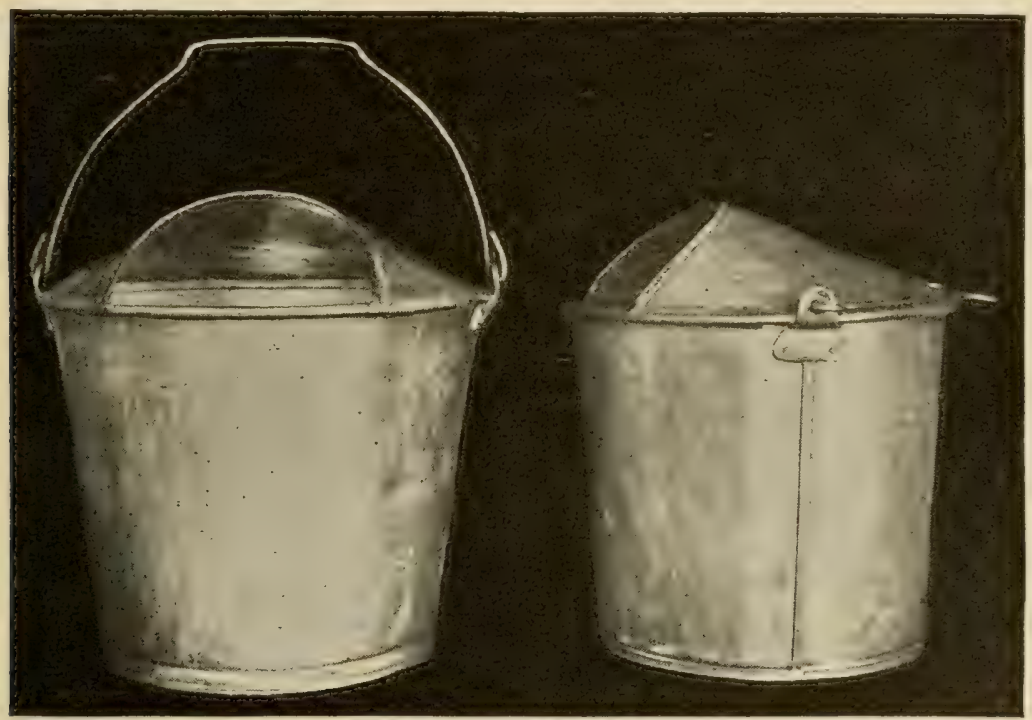

Fig. 71. - Truman Sanitary Milk Pail. (Stors, Conn. Station.)

use made of this milk by the better informed people who realize the unsanitary condition of average market milk. Certified milk is the means of saving the lives of thousands of infants and its increasing use offers splendid opportunities for dairymen who are in a position to meet the requirements laid cown by medical commissions.

Production and Handling. The general conditions called for in the production of "certified" milk are essentially the same as those stated in the chapter on "sanitary milk production." 
The cows, milkers and premises are regularly inspected, and the milk is regularly subjected to chemical and bacteriological tests. The number of bacteria permitted by different commissions varies from 10,000 to 30,000 per cubic centimeter of milk; and the fat content ranges from about 3.5 to 4.5 per cent.

The milk bottles are sealed preferably with metallic caps bearing the date of bottling and the name of the commission. Delivery should be made within twentyfour hours after the milk is drawn and its temperature during this time should not exceed $45^{\circ} \mathrm{F}$.

In the dairy house arrangements must be such as to reduce contamination to a minimum. A receiving can placed in an ante-room is used by the milkers to empty their pails, and from this the milk is conducted into the milk room. A sterilizer with doors at both ends is preferably placed between the milk room and the wash room, so as to enable the milkers to get their pails without entering the milk room and, at the same time, to allow the sterilized bottles to be removed without entering the wash room.

Profits. Obviously it costs more to produce certified than average market milk, but the additional cost is less, as a rule, than the increased price realized. Certified dairies that have failed to make money have almost invariably invested more money in buildings and equipment than was actually necessary. It has been shown that this class of milk may be successfully produced in quite ordinary buildings and with moderately cheap equipment. What is of greatest importance is extreme cleanliness, which is achieved mainly through intelligent care and management of every detail of the work from start to finish. 


\section{CHAPTER XXXI.}

RELATIVE MARKE,T VALUE OF MILK AND ITS PRODUCTS.

Many milk producers are so situated as to make it possible for them to sell either milk, cream, butter, cheese or ice cream. To those so situated the question naturally arises, what method of disposal will yield the largest returns? This, of course, will depend to a great extent upon the relative market prices of these products.

To show how dairymen may determine for themselves in what form they can realize most for their milk, a simple method of calculation is here presented, in which, for purposes of illustration, the following prices have been adopted: Milk, seven cents per quart; $30 \%$ cream, one dollar per gallon; butter, twenty-five cents per pound; cheese, thirteen cents per pound; and ice cream, made from $15 \%$ cream, one dollar per gallon. Using these as average prices for a given locality, determine the relative returns from one hundred pounds of milk containing $4 \%$ ( 4 lbs.) butterfat, (I) when retailed as milk, (2) when sold as cream, (3) when sold as butter, (4) when sold as cheese, and (5) when sold as ice cream.

I. Value of Milk. Since milk weighs 2.I5 pounds per quart, IOO pounds of $4 \%$ milk are equal to 46.5 quarts, which, at 7 cents per quart, are worth $\$ 3.25$.

2. Value of Cream. One hundred pounds of $4 \%$ milk will make $\mathrm{I} 3.33$ pounds of $30 \%$ cream, as determined by the following rule: 
Rule: To find the number of pounds of cream that can be obtained from a given amount of milk, multiply the milk by its test and divide the product by the test of the cream. Thus the amount of $30 \%$ cream from IOo pounds of milk testing $4 \%$ equals

$$
\frac{100 \times 4}{30}=\mathrm{I} 3.33 \text { pounds. }
$$

Since a gallon of $30 \%$ cream weighs practically the same as a gallon of water $(8.35 \mathrm{lbs}$.), the $\mathrm{I} 3.33$ pounds of cream are equal to I.6 gallons which, at $\$ \mathrm{I}$.OI per gallon, are worth \$I.6o. Allowing one-half cent per pound for skim-milk, we have 43 cents as the value of the 86 pounds of skim-milk, which gives a total value of $\$ 2.03$ for the Ioo pounds of $4 \%$ milk.

2. Value of Butter. One hundred pounds of $4 \%$ milk will yield 4 2-3 pounds of butter, because where up-todate methods of creaming and churning are followed every pound of butterfat will make I I-6 pounds of butter. Four and two-thirds pounds of butter at 25 cents per pound are worth $\$$ I.I7. Valuing buttermilk at the same price as skim-milk (one-half cent per pound) 48 cents should be added to the \$I.I7 as the value of the skim-milk and buttermilk, making a total value of $\$$ I.65 for the Ioo pounds of $4 \%$ milk.

4. Value of Cheese. Since one pound of butterfat yields approximately 2.6 pounds of cured cheddar cheese, IOO pounds of $4 \%$ milk will make $4 \times 2.6$, or I0.4 pounds of cheese, which, at I3 cents per pound, are worth $\$ 1.35$. Allowing ro cents as the value of the whey from the roo pounds of $4 \%$ milk, we get a total value of $\$ 1.45$. 
5. Value of Ice Cream. Since a gallon of I5\% cream weighs 8.45 pounds, IOO pounds of $4 \%$ milk will make 3.I 5 gallons of $15 \%$ cream (see formula for calculating. cream, p. 240) or, allowing an overrun of 33 I-3\%, 4.2 gallons of ice cream. At $\$ 1.00$ per gallon this is worth $\$ 4.20$. To this must be added the value of 73 pounds of skim-milk which, at one-half cent per pound, are worth 37 cents, making a total value of $\$ 4.57$ for the Ioo pounds of milk made into ice cream.

Summary. The preceding calculations show that Ioo pounds of $4 \%$ milk are worth

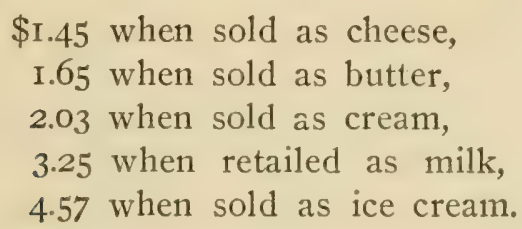

It is to be remembered that the above figures show the relative gross returns at the prices given. The net returns will vary greatly, depending largely upon the nearness to market and the quantity of milk handled; also to some extent upon the use to which the skim-milk is put. If fed to pigs and calves the value of skim-milk is less than one-half cent per pound; if made into buttermilk or cottage cheese its value may range from one to two cents per pound.

Table of Values. The following table of values has been prepared for handy reference. The price of milk is used as a basis, and the table shows at what prices cream and butter must be sold to give the same returns as milk: 


\begin{tabular}{|c|c|c|c|c|}
\hline $\begin{array}{l}\text { Per Cent. of } \\
\text { Fat in Milk }\end{array}$ & $\begin{array}{c}\text { When Milk } \\
\text { sells at }\end{array}$ & $\begin{array}{l}20 \% \text { Cream } \\
\text { must sell at }\end{array}$ & $\begin{array}{l}30 \% \text { Cream } \\
\text { must sell at }\end{array}$ & $\begin{array}{c}\text { Butter } \\
\text { must sell at }\end{array}$ \\
\hline 3.5 & 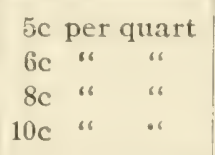 & 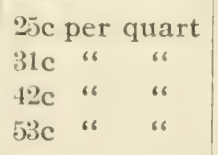 & $\begin{array}{l}36 \mathrm{c} \text { per quart } \\
43 \mathrm{c} \text { “ } \\
59 \mathrm{c} \text { " } \\
75 \mathrm{c}\end{array}$ & 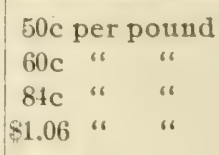 \\
\hline 4.0 & $\begin{array}{l}\text { 5c per quart } \\
6 c \text { " " } \\
8 c \text { " " } \\
10 c \text { " }\end{array}$ & 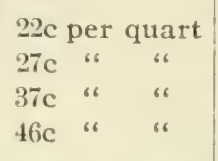 & $\begin{array}{l}31 \mathrm{c} \text { per quart } \\
38 \mathrm{c} \text { " " } \\
50 \mathrm{c} \text { " " } \\
66 \mathrm{c} \text { " }\end{array}$ & 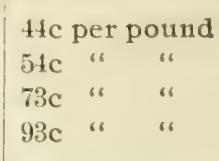 \\
\hline 4.5 & $\begin{array}{l}\text { 5c per quart } \\
6 c \text { " " " } \\
8 c \text { " " } \\
10 c \text { " }\end{array}$ & $\begin{array}{l}20 \text { c per quart } \\
24 c \text { " " " } \\
32 c \text { " " } \\
41 c \text { " }\end{array}$ & 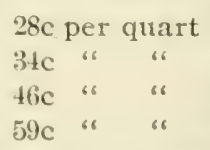 & $\begin{array}{l}39 \mathrm{c} \text { per pound } \\
47 \mathrm{c} " \text { " } \\
65 \mathrm{c} \text { " } \\
82 \mathrm{c} "\end{array}$ \\
\hline 5.0 & 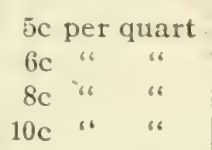 & 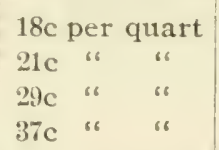 & $\begin{array}{l}25 \text { c per quart } \\
30 \mathrm{c} \text { " " } \\
42 \mathrm{c} " \\
53 \mathrm{c} "\end{array}$ & $\begin{array}{l}35 \mathrm{c} \text { per pound } \\
43 \mathrm{c} " \text { " } \\
59 \mathrm{c} " \\
75 \mathrm{c}\end{array}$ \\
\hline
\end{tabular}

In calculating the above values, skim-milk and buttermilk have been rated at 30 cents per Ioo pounds. The weight allowed per quart is as follows: Milk, 2.15 pounds ; $20 \%$ cream, 2.I pounds; and 30\% cream, 2.0 pounds. The cost of handling and retailing these products, as well as the cost of making the butter, has not been considered.

From the table it will be seen that when $3.5 \%$ milk sells at 5 cents per quart, $20 \%$ cream must sell at 25 cents per quart, $30 \%$ cream at $3^{6}$ cents per quart, and butter at 50 cents per pound, to vield equivalent returns. Similarly, when $5 \%$ milk sells at 5 cents per quart, $20 \%$ cream must sell at I8 cents per quart, $30 \%$ cream at 25 cents per quart, and butter at 35 cents per pound.

'The table emphasizes the importance of selling milk on the basis of its fat content. 


\section{PART III. \\ S U P P LEM EN T}




\section{CHAPTER XXXII.}

ESTIMATING THE VALUE OF DAIRY STOCK.

\section{Valuing Corws.}

To put dairying on a business basis requires that a record be kept of each cow individually. This is important not only to determine which cows are paying for their keep, but also to demonstrate to owners that high producers, as a rule, are valued too low in comparison with poor producers. Every cow must be valued according to the net returns obtained from her; that is, every item of expense must be deducted from the total receipts in order to know whether a cow has been kept at a profit or a loss. In the following paragraphs data are presented to show the method of determining the net profits as well as to give some idea of the relative value of cows of different productive capacities. The figures presented are based upon pure bred herds containing thirty cows and one bull each. Furthermore, it is assumed that all concentrated feeds are purchased at market prices and that all roughage is raised on the farm and charged at actual cost of production. To furnish the necessary ronghage and pasture, one and one-half acres of land are allotted to each cow, one-half of which is devoted to pasture and the other half to hay and forage production. Eight years has been allowed as the period of usefulness of a cow. 
Three cows have been selected whose annual butter fat production is 200,300 and 400 pounds respectively. The receipts, expenditures and net profits from the three different producers, Cow I, Cow II and Cow III, are shown as follows:

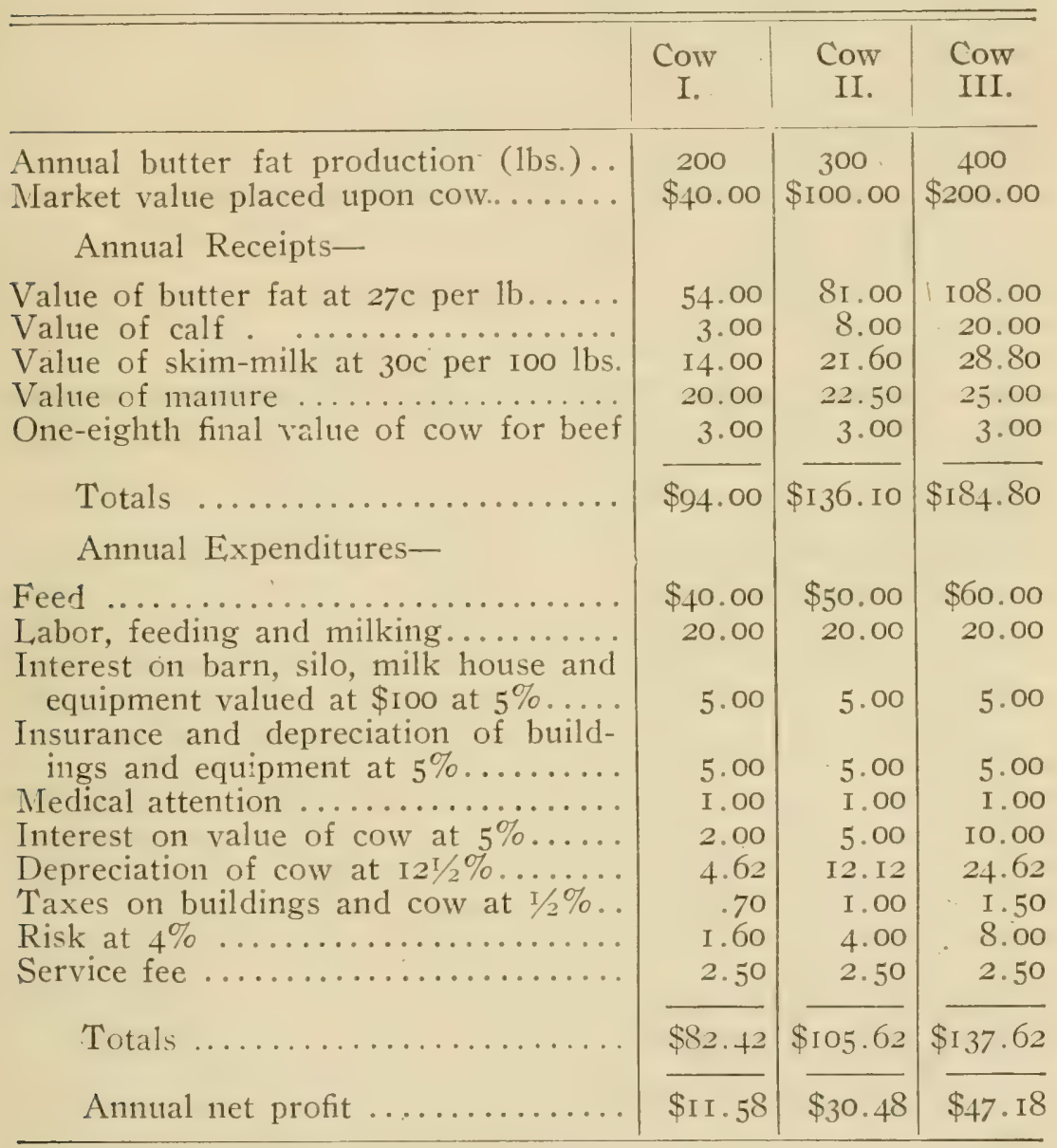

EXPLANATION OF ABOVE FIGURES.

Price of Butter Fat. Prevailing prices of butter and cheese have been such as to yield farmers having their 
milk made into these products, an average price for the year of 27 cents per pound of butter fat.

Value of Calf. A calf from a cow producing only 200 pounds of butter fat a year must be valued at beef prices, which amounts to about $\$ 3.00$ at birth. When the production reaches 300 pounds of butter fat and up, the value of the calf rapidly increases, as indicated in the tables. The price placed upon the calves from the larger producers it is believed, is a fair average market value. Their actual value is considerably greater than this.

Value of Skim=Milk. For the purpose of this calculation, the amount of skim-milk credited to each cow is based upon a $4 \%$ fat content of the milk and represents the total milk minus the butter fat it contains. While rating the value of skim-milk at 30 cents per IoO pounds may be considered too high by some, it must be remembered that skim-milk has a fertilizing value which alone amounts to at least Io cents per IoO pounds, and fully three-fourths of this is recovered in the manure. For poultry, young calves, and young pigs, the combined feeding and fertilizing value of skim-milk is higher than 30 cents, especially when fed in a small quantity.

Value of Manure. The manure from cows considered in the preceding table is valued according to its content of nitrogen, phosphoric acid and potash, which according to their present commercial ratings are worth 19,5 , and 5 cents per pound respectively. The fertilizing ingredients vary with the kind and amount of feed supplied, and this again varies according to the productive capacity of cows and, to some extent, the section of the country in which the cows are fed. Largely because of these condi- 
tions, the values here obtained are intended to be used as general averages only.

In fixing the value of the manure from cows of different productive capacities, $\$ 15$ is allowed as the value of the manure from the feed required for maintenance and for the development of the foetus. In this connection it should be remembered that the one and one-half acres of land allotted per cow are intended to supply all of the roughage needed, and this should contain nutrients sufficient for maintenance requirements. On one-half of this land there is grown, say, one ton of red clover hay and three tons of corn silage, which contain fertilizing ingredients to the value of $\$ \mathrm{I}_{3} .62$. If one-half of this amount is allowed as the value of the fertilizing ingredients contained in the pasture from the other half of the land, the total value of the fertilizing constituents contained in the feed required for maintenance is $\$ 20.00$. Some of the fertilizing constituents enter into the foetus, but it is safe to say that three-fourths of them, or $\$ 15$ worth, pass into the manure. This maintenance feed, and its value as a fertilizer, is quite constant for cows of different productive capacities. Additional manurial value is, therefore, obtained from the amount of concentrated feeds supplied for milk production. According to European and American figures, this amount is approximately 800 pounds for each 2,500 pounds of $4 \%$ milk, or for each Ioo pounds of butter fat, produced.

The manurial value of each pound of the common concentrates varies from three-eighths cent for corn to about one and one-fourth cents for cottonseed meal and linseed meal, with intervening values of three-fourths cent for wheat bran, dried brewers grains and gluten feed, and 
about one cent for gluten meal. From these values it is safe to assume an average of five-eighths cent per pound which gives the 800 pounds of concentrates a manurial value of $\$ 5.00$. Since milk has a manurial value of about Io cents per 100 pounds, the manurial value of the 2,500 pounds of milk is $\$ 2.50$, which leaves $\$ 2.50$ as the value of manurial constituents that actually enter into the manure for each 2,500 pounds of milk, or each IoO pounds of butter fat, produced. For each Ioo pounds of butter fat produced, therefore, $\$ 2.50$ is added to $\$ I 5$ which is the estimated value of the manure from feed required for maintenance.

The value of the manure from cows of different productive capacities, as obtained in the above calculation, is based upon the assumption that all of the manure is saved. Unfortunately, however, many dairymen allow one-half or more of it to go to waste, but such carelessness on the part of dairymen should not be charged against the cow.

While the value of the manure has been based solely upon its content of nitrogen, phosphoric acid and potash, manure has values outside of these ingredients. Its mechanical effect upon the soil through the humus it supplies, as well as the beneficial effects of the hosts of bacteria it contains, should not be underrated.

Value of Cow for Beef. The final value of a cow to the butcher may be placed at $\$ 24$. Since the cow may be milked on an average eight years, one-eighth of the $\$ 24$, or $\$ 3$, should be credited to her annual receipts.

Cost of Feed. On arriving at the cost of feed, it is to be remembered that one and one-half acres of land is allotted to each cow. This land, valued at $\$ 80$ per acre, will undoubtedly furnish enough pasture and other rough 
feeds to meet the usual maintenance requirements. In determining the cost of the forage grown on this land, $\$ 6.60$ is charged as the interest and taxes on the value of the land, $\$ 3.40$ as the cost of fencing, and $\$$ IO as the cost of the labor and seed required to raise the roughage on three-fourths acre of land. This makes a total of $\$ 20$, the cost of maintenance.

As stated above, approximately 800 pounds of grain or its equivalent, is required to produce 2,500 pounds of milk testing 4 per cent butter fat. This grain has an average market value of about $\$ 10$. To the $\$ 20$, the cost of maintenance, must therefore be added \$Io for each 2,500 pounds of milk, or for each 100 pounds of butter fat, produced.

Net Profits: The market value placed upon the cows is assumed to be the average price that one is obliged to pay when purchasing them. Where the cows are valued according to the actual cost of raising them, the net profits would be considerably higher than those shown in the preceding table, especially from the higher producers, as witness the following table in which the "net profits when the cow is raised," are based upon the cost of the cow as determined under "valuing calves," page 250 .

\begin{tabular}{|c|c|c|c|}
\hline Annual Butter Fat Production ...... Pounds & 200 & 300 & 400 \\
\hline $\begin{array}{l}\text { Net Profit when Cow is Bought........... } \\
\text { (From Table, Page 245) }\end{array}$ & $\$$ I I. $5^{8}$ & $\$ 30.48$ & $\$ 47.18$ \\
\hline Net Profit when Cow is Raised ...... & I I. $5^{8}$ & $42 \cdot 3^{8}$ & $77 \cdot 98$ \\
\hline
\end{tabular}

The higher net profits from cows raised upon the farm are due to their lower cost to the dairymen, reducing the following expenses based upon the cost of the cow; risk, taxes, interest and depreciation. 


\section{VALUING CALVES.}

As a rule, calves from high-class cows are sold at prices considerably below their actual value. This is so because few dairymen appreciate the full value of calves firom high producers. Not until such calves have grown into young cows is it possible to realize anywhere near their full market value, and hence the wisdom of selling young milch cows instead of calves.

In the receipts from cows of different productive capacities shown on page 245 , the values assigned to the calves from the higher producers are low as compared with the market price of cows of similar productive capacities. This is best shown by first calculating the approximate cost of raising calves from cows of different productive capacities, up to the time of dropping their first calf, namely, two years old, as follows:

\begin{tabular}{|c|c|c|c|}
\hline Value of calf at birth ........... & $\begin{array}{c}\text { From 200- } \\
\text { pound Cow. } \\
\$ 3.00\end{array}$ & $\begin{array}{l}\text { From 300- } \\
\text { pound Cow. } \\
\$ 8.00\end{array}$ & $\begin{array}{l}\text { From } 400- \\
\text { pound Cow. } \\
\$ 20.00\end{array}$ \\
\hline 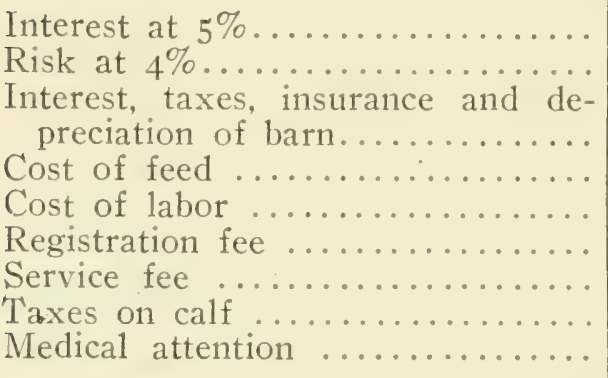 & $\begin{array}{r}\$ 0.30 \\
.24 \\
1.50 \\
40.00 \\
10.00 \\
2.00 \\
2.50 \\
.20 \\
.20\end{array}$ & $\begin{array}{r}\$ 0.80 \\
.64 \\
1.50 \\
40.00 \\
10.00 \\
2.00 \\
2.50 \\
.20 \\
.20\end{array}$ & $\begin{array}{r}\$ 2.00 \\
1.60 \\
\\
1.50 \\
40.00 \\
10.00 \\
2.00 \\
2.50 \\
.20 \\
.20\end{array}$ \\
\hline $\begin{array}{l}\text { Total cost } \ldots \ldots \ldots \ldots \ldots \ldots \ldots \\
\text { Value of manure............ }\end{array}$ & $\begin{array}{l}\$ 56.94 \\
20.00\end{array}$ & $\begin{array}{r}\$ 57.84 \\
20.00\end{array}$ & $\begin{array}{r}\$ 60.00 \\
20.00\end{array}$ \\
\hline Net cost at two years old ...... & $\$ 36.94$ & $\$ 37.84$ & $\$ 40.00$ \\
\hline
\end{tabular}


This table shows that the cost of raising an ordinary two-year-old heifer may be taken on an average to be $\$ 37$ and that this cost is not materially increased for highclass heifers.

The following table shows that the market value assigned to calves from the higher producing cows is low in comparison with the market value of the cows themselves:

\begin{tabular}{|c|c|c|c|}
\hline & \multicolumn{3}{|c|}{ Offspring from } \\
\hline & $\begin{array}{l}200-1 b . \\
\text { cow. }\end{array}$ & $\begin{array}{l}300-1 b \\
\text { cow. }\end{array}$ & $\begin{array}{l}400-1 b \\
\text { cow. }\end{array}$ \\
\hline Market value of calf at birth ...... & $\$ 3.00$ & $\$ 8.00$ & $\$ 20.00$ \\
\hline $\begin{array}{l}\text { Cost of raising calf up to two years } \\
\text { old } \ldots \ldots \ldots \ldots \ldots \ldots \ldots \ldots \ldots \ldots \ldots \\
\end{array}$ & 36.94 & 37.84 & $\$ 40.00$ \\
\hline Total cost of two-year-old heifer.... & $\$ 39.94$ & $\$ 45.84$ & $\$ 60.00$ \\
\hline Market value two-year-old heifer... & 40.00 & 100.00 & 200.00 \\
\hline $\begin{array}{l}\text { Increased net profit from selling } \\
\text { heifer instead of calf............. }\end{array}$ & $\$ 0.06$ & $\$ 54.16$ & $\$ I 40.00$ \\
\hline
\end{tabular}

The table shows that it is unquestionably more profitable to keep heifer calves until two years old than to sell them as calves.

\section{VALUING BULIS.}

In estimating the relative value of bulls capable of producing cows yielding annually 200, 300 and 400 pounds of butter fat respectively, it is assumed that each bull will produce fifteen heifer calves and fifteen bull calves annually. The relative value of the heifers from the different bulls, is based upon the relative net profits obtained from the cows as determined under "Valuing Cows," page 244 . The bull calves from the different bulls are 
given values corresponding to those given the calves in the calculation just referred to.

Since cows producing only 200 pounds of butter fat a year are maintained at only a small profit, bulls capable of producing such cows will not be considered here. By referring to the figures showing the net profits from cows of different productive capacities it will be found that cows yielding 400 pounds of butter fat a year will produce annually $\$ 16.70$ more net profit than those yielding 300 pounds of butter fat. The immediate increased value of the fifteen heifer calves from the 400-pound bull will, therefore, amount to $\$ 16.70 \times{ }_{15}$, or $\$ 250.50$.

Since these heifers will produce for a period of eight years, the real annual increased value represented by the fifteen heifer calves fiom the better bull will amount to $\$ 250.50 \times 8$ or $\$ 2,000.00$. Adding to this $\$ 180$ as the increased value of the fifteen bull calves, we have a total of $\$ 2,184$ which represents the total annual increased value of the offspring from the 40o-pound bull over that of the 3oo-pound one. Allowing six years as the period of usefulness of bulls, we get a grand total of \$13,IO4 in favor of the 4oo-pound bull during his six-year period of usefulness.

If we value the 300-pound bull at forty dollars and the $400-$ pound bull at $\$_{15} \mathrm{O}$, it will be necessary to deduct from the above the difference in the interest, taxes, risk and depreciation of the two bulls. These items, if figured the same as for cows, will amount to $\$$ I 72.68 for six years, leaving a net profit of $\$ 13,03 \mathrm{I} .32$ in favor of the $400-$ pound bull during his period of usefulness.

If we value heifer calves according to the net profits obtained from cows when the latter are raised upon the farm, the differences found above will be considerably greater. 


\section{CHAPTER XXXIII.}

\section{LEGUMES (ALFALFA AND CLOVERS).}

One of the greatest factors in successful dairying at the present time is the growing of an ample supply of leguminous crops, such as alfalfa and clovers. There are several reasons for this: ( I) legumes improve the soil by adding to its store of nitrogen; (2) legumes are rich in protein and can, therefore, take the place, to a great extent, of high priced commercial feeds rich in protein.

The bacteria that live upon the roots of alfalfa and clovers have the power of taking the nitrogen from the air and putting it into the soil in a form in which it becomes available for plant growth. Nitrogen when purchased in the form of commercial fertilizers, has a value of about twenty cents per pound. The dairyman who grows a sufficient quantity of clover and alfalfa gets the nitrogen absolutely free and in sufficient quantity not only to maintain the supply of nitrogen already in the soil, but by feeding the clover and alfalfa to stock the nitrogen content of the soil can be materially increased.

With the increasing cost of commercial feeds rich in protein, it manifestly is a matter of economy for the dairy farmer to raise crops upon his farm which can take the place of expensive commercial feeds. There is no home grown feed which can take the place of grain or concentrated commercial feeds to so great an extent as alfalfa. This will be readily understood when it is known that 
practical feeding trials have shown that good alfalfa hay has, pound for pound, the same value for milk production as wheat bran. It is generally known that red clover and other kinds of clover are rich in protein, but alfalfa is still richer in protein.

Where conditions are favorable for growing alfalfa, there is perhaps no general farm crop that yields so great returns from an acre of land as alfalfa, especially when considering its favorable effect upon the soil. In favored localities alfalfa can be cut four times during each season, yielding from four to five tons per acre.

The roots of alfalfa penetrate the soil to great depths and for this reason, when once establisher, alfalfa will flourish during dry seasons when ordinary crops fail. Noreover, the deep root system of alfalfa enables it to obtain plant food from such soil depths as are entirely beyond the reach of ordinary farm plants.

Alfalfa is a plant highly relished by all classes of live stock, though it cannot be as successfully grazed, perhaps, as red clover, at least not until it has passed through the second season; but, unlike red clover, alfalfa will continue to yield good crops of hay many years without replanting. It is well to remember that alfalfa does not thrive everywhere. It requires a well drained soil rich in lime and containing the right kind of bacteria. In limestone regions where sweet clover flourishes, alfalfa probably grows at its best. This plant is so valuable to dairymen that none can afford not to try to grow it.

\section{LEGUME HAY AND CORN SILAGE.}

Where a liberal allowance of rich legume hay is fed in conjunction with corn silage, little grain or concen- 
trates is required, except for heavy producers. Silage helps to balance the legume ration and supplies the succulence which the legume hay lacks. 'The two feeds, therefore, nicely supplement each other, not only so far as succulence is concerned, but also with respect to protein and carbohydrates.

For economical milk production it may be stated without fear of contradiction that there is no combination of winter feeds equal to legume hay and corn silage, supplemented with grain or concentrates according the yield of milk. It is economy also to feed silage and legume hay during periods when pastures are short. Especially important is it to have silage for summer feeding, a matter which is recognized now-a-days by leading dairymen everywhere. 


\section{CHAPTER XXXIV.}

THE DAIRY HOUSE.

Location. In selecting a site for a dairy house, convenience and sanitation should be given first consideration. A well drained spot, free from rubbish and bad odors, and within reasonable distance from the barn should be selected. An abundance of good, pure water must be available.

Floor Plans Designed by the Author. Dairyment who sell milk and cream occasionally have a surplus of these products on their hands, which is usually made into butter. Floor plans for dairy houses must therefore provide for small buttermaking outfits in addition to all the necessary apparatus for the handling of milk and cream.

The floor plan shown in Fig. 72 is designed to meet the needs of small dairymen. Figs. 73 and 76 illustrate plans which will answer the needs of dairymen having from twenty to fifty cows. The first two plans provide for retail milk; the last provides for farm buttermaking. There is no question that refrigerating machinery can be employed very advantageously in a great percentage of the larger dairies.

Details of Construction. The foundation for the walls may be constructed of stone, brick or concrete. It should rest upon firm, solid ground below the frost line, and the top must be at least one foot above ground.

In building the walls, place the studs two feet apart 


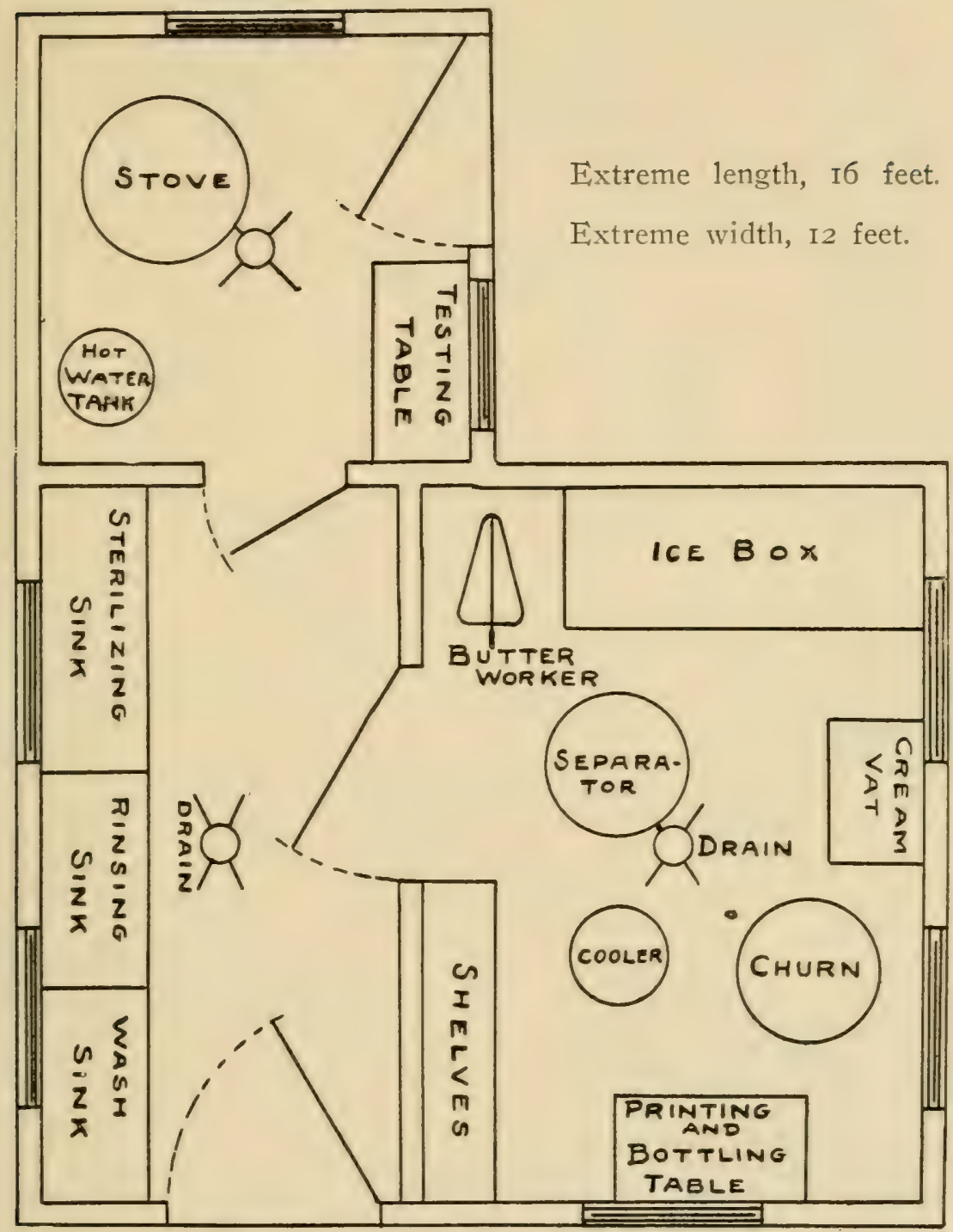

Fig. 72-Filoor Plan of Dairy House for Retail Milk.

and tack building paper on both sides. Weather board the outside and finish the inside as follows: Board up preferably with tongued and grooved lumber, and cover the boards with two thicknesses of 


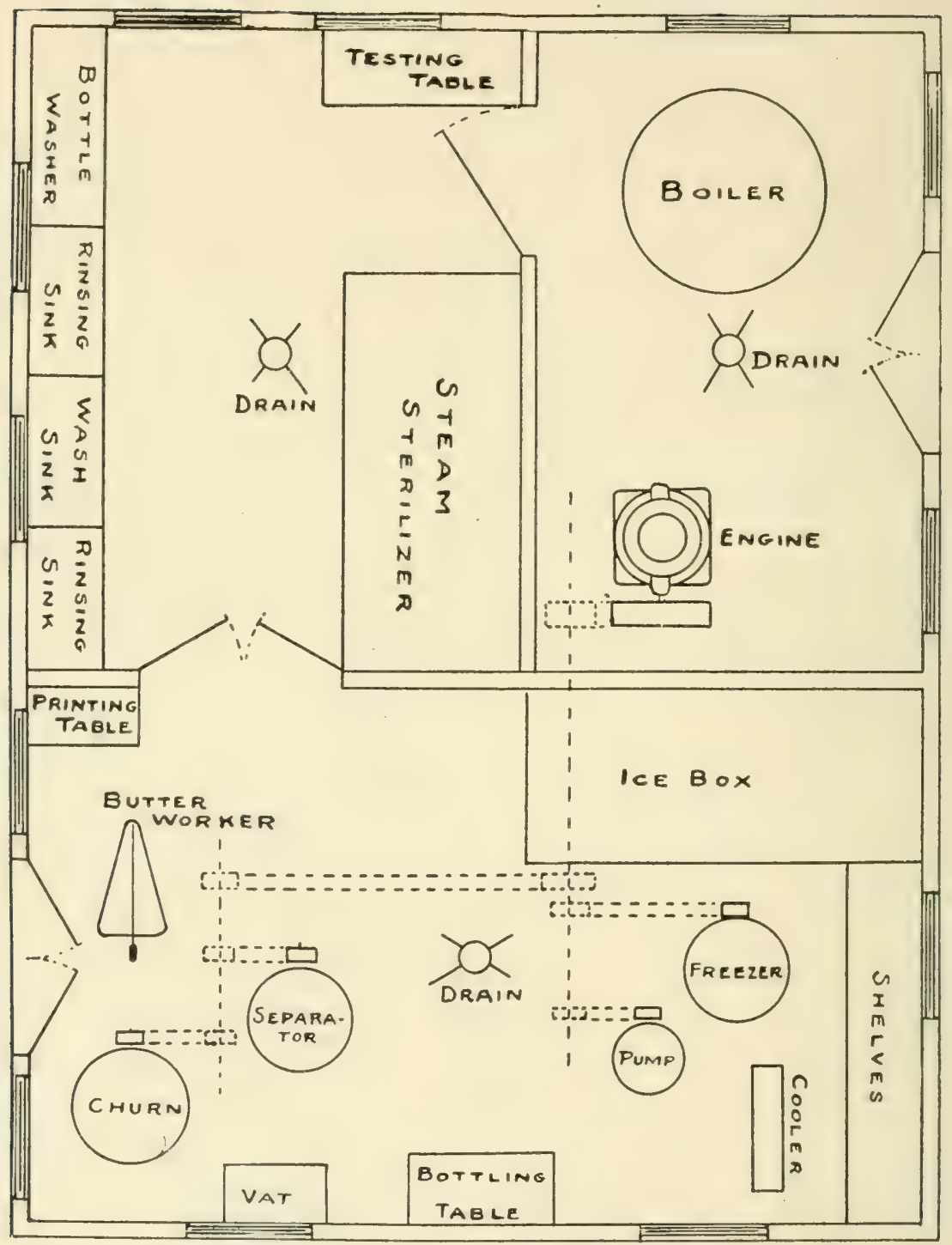

Fig. 73.-Floor Plan of Dairy House for Retail Milk Trade, Suitable for Fifty Cows. 18'x24'.

roofing paper. Next put on furring strips, one foot apart, and to these fasten wire lathing. If the lathing is provided with one-inch steel ribs the furring strips are not 
needed. Next apply one and one-half inches of cement plaster consisting of one part cement, three parts clean, coarse sand, and one part slacked lime paste. Press the

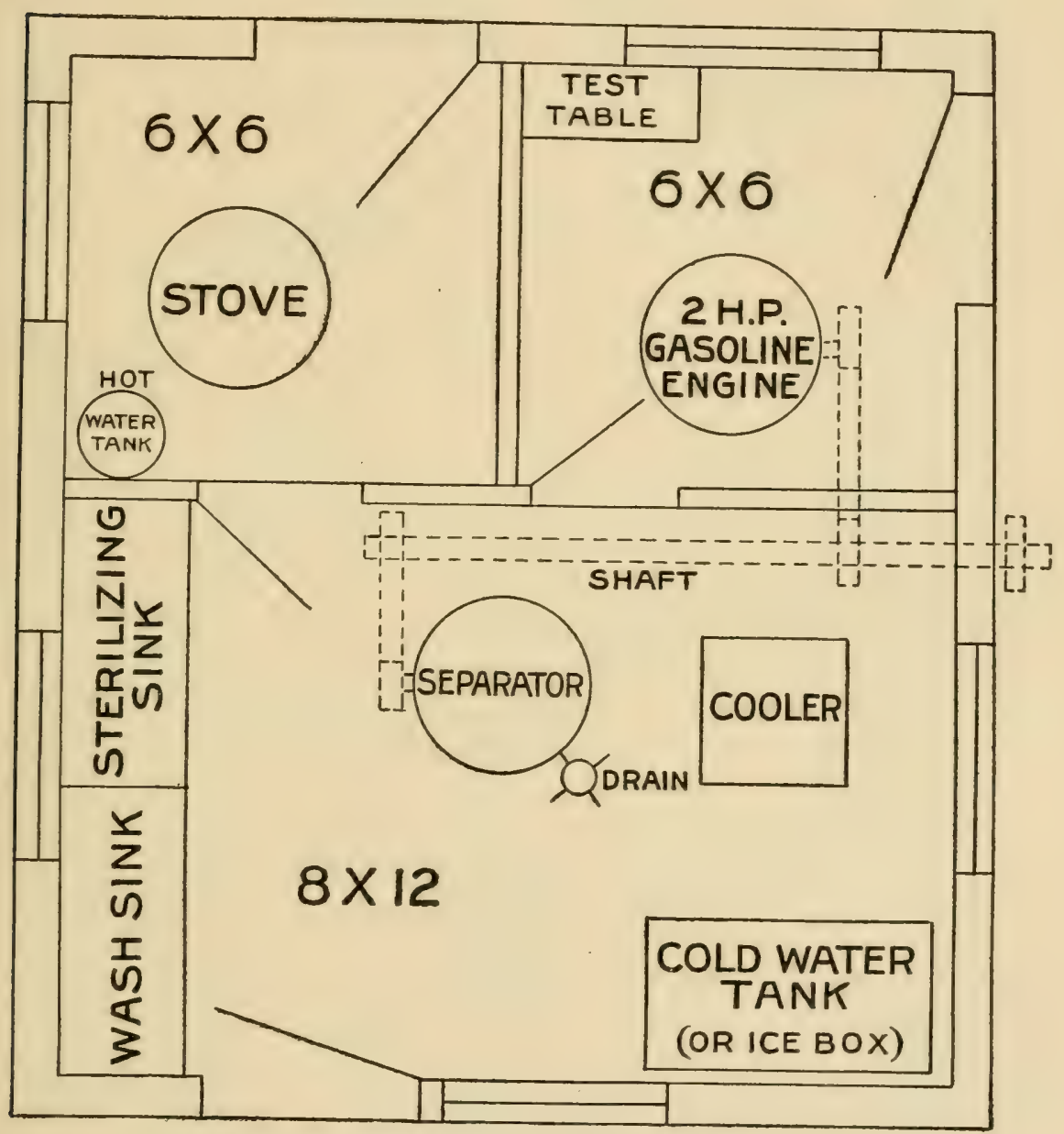

Fig. 74,-Milk House for Cream Patrons.

concrete partly through the wire lathing. Finish with one part cement and one part sand and trowel off as smoothly as possible. This construction provides one three-fourths inch and one four-inch dead air spaces. 


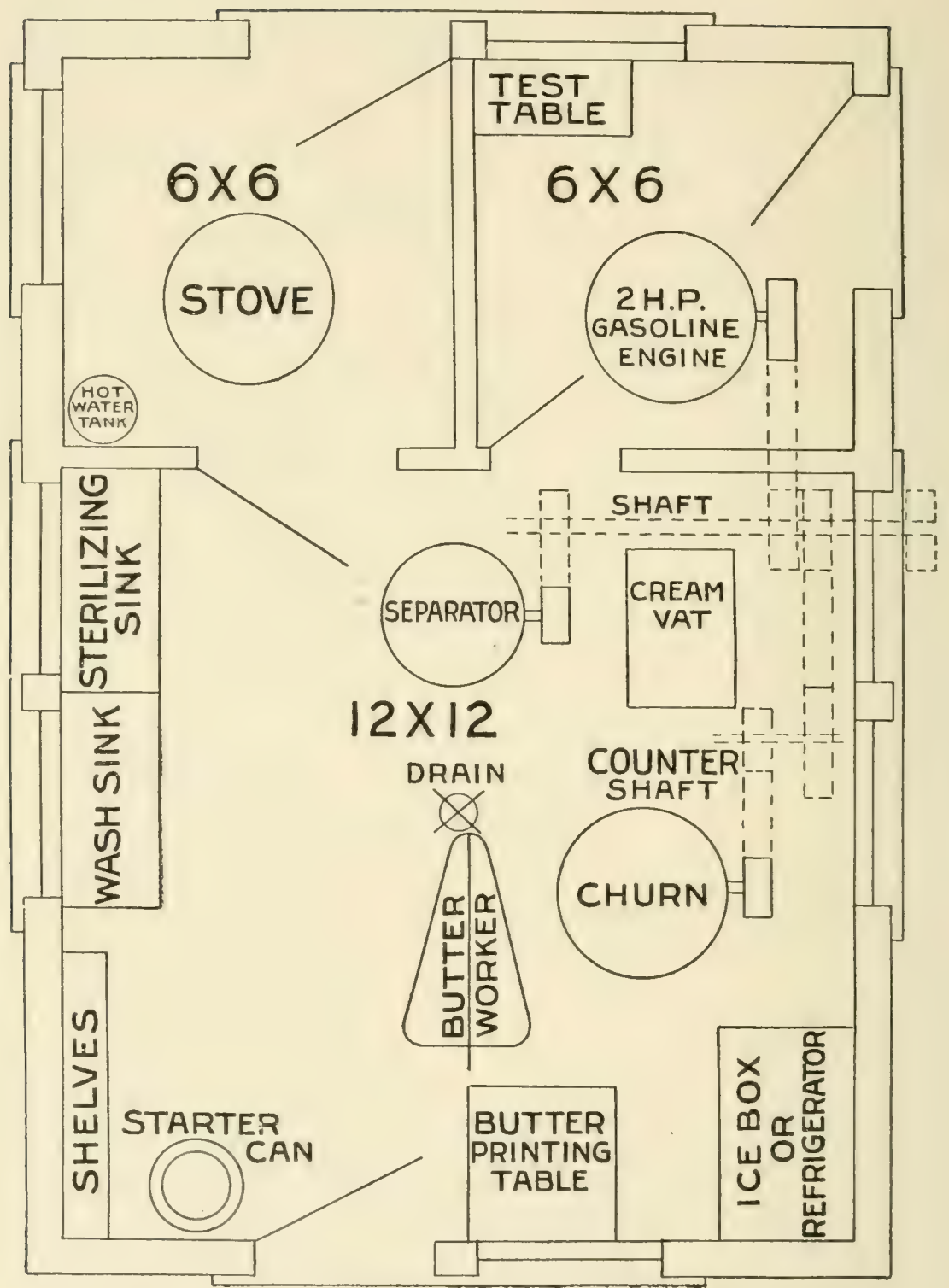

Fig. 76.-Floor Plan of Dairy House for Farm Buttcimaking. 
Construct a four-inch concrete floor upon a well tamped foundation consisting of gravel, cobble stones and cinders.

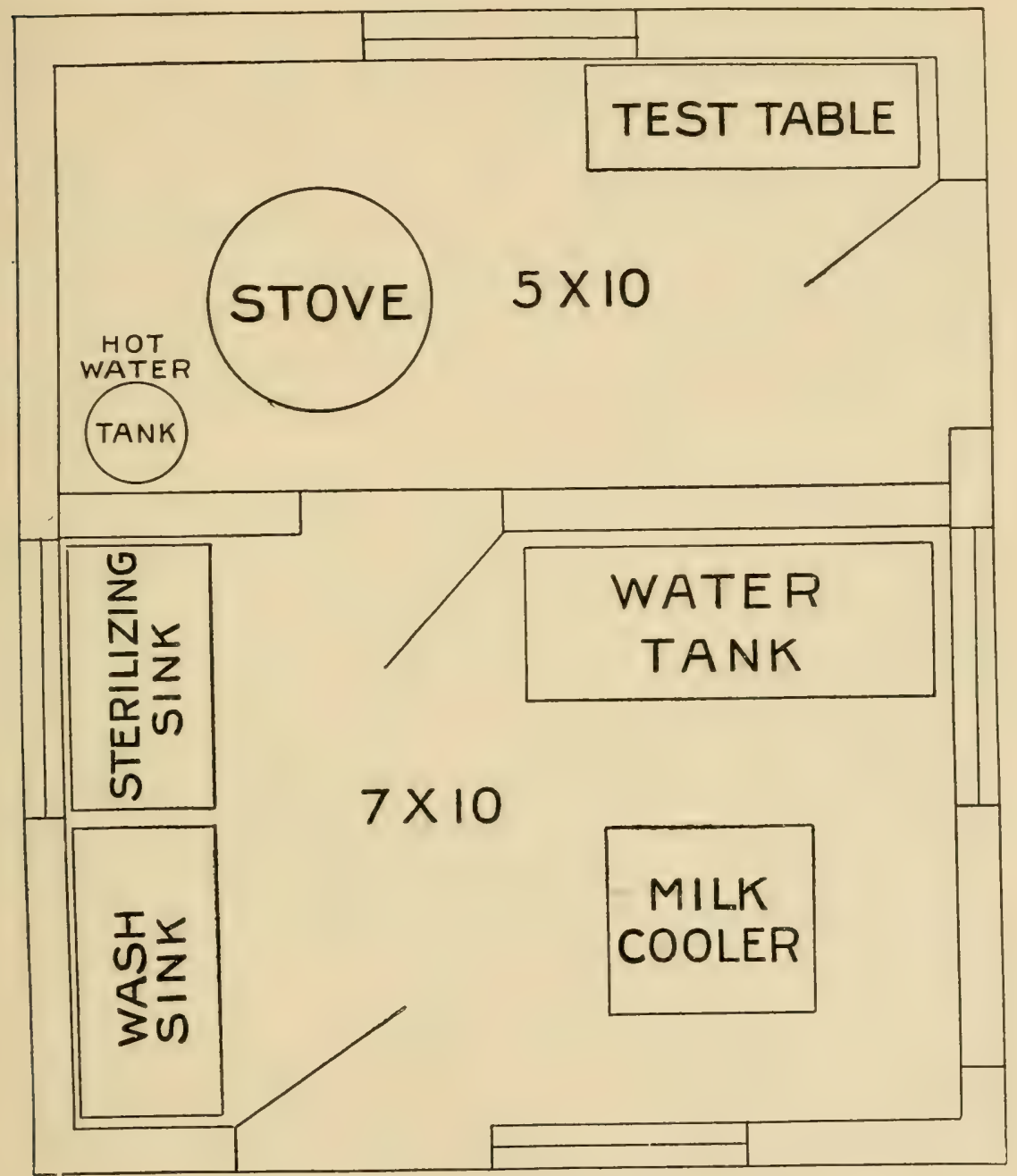

Fig. 75.-Milk House Whole Milk Patrous.

These materials afford good drainage and thus prevent the cold and dampness usually associated with concrete floors. In preparing the concrete for the floor iise one part 
cement, two parts clean, coarse sand and four parts gravel or crushed stone. Finish with one part cement and two parts sand.

All parts of the floor should slope toward the drain in the center. Round out the corners and edges of the floor with concrete to make them more easily cleanable.

The ceiling should be about twelve feet high and built of the best ceiling lumber. Keep the ceiling well painterl.

Enough windows must be provided to afford ample light and to admit sunshine to all parts of the building.

Provide ventilation in the milk and wash rooms by running tight ventilating shafts from the ceiling through the top of the roof.

Sewerage: Effective sewerage must be provided at the time the floor is laid. A bell trap should be placed in the center of each room and carefully connected with the sewer. Conduct the sewage far enough away to keep its odors a safe distance from the dairy house.

Screening. Where proper sanitation is expected it is absolutely necessary to guard against flies, and this can easily be done by screening all doors and windows. Flies are a prolific source of milk contamination and must therefore be rigidly excluded from the dairy. 


\section{CHAPTER XXXV.}

WASHING AND STERILIZING MILK VESSELS.

Wash Sinks. A matter of importance in washing milk vessels is to have the right kind of sinks, three of which are needed for the most satisfactory work: One

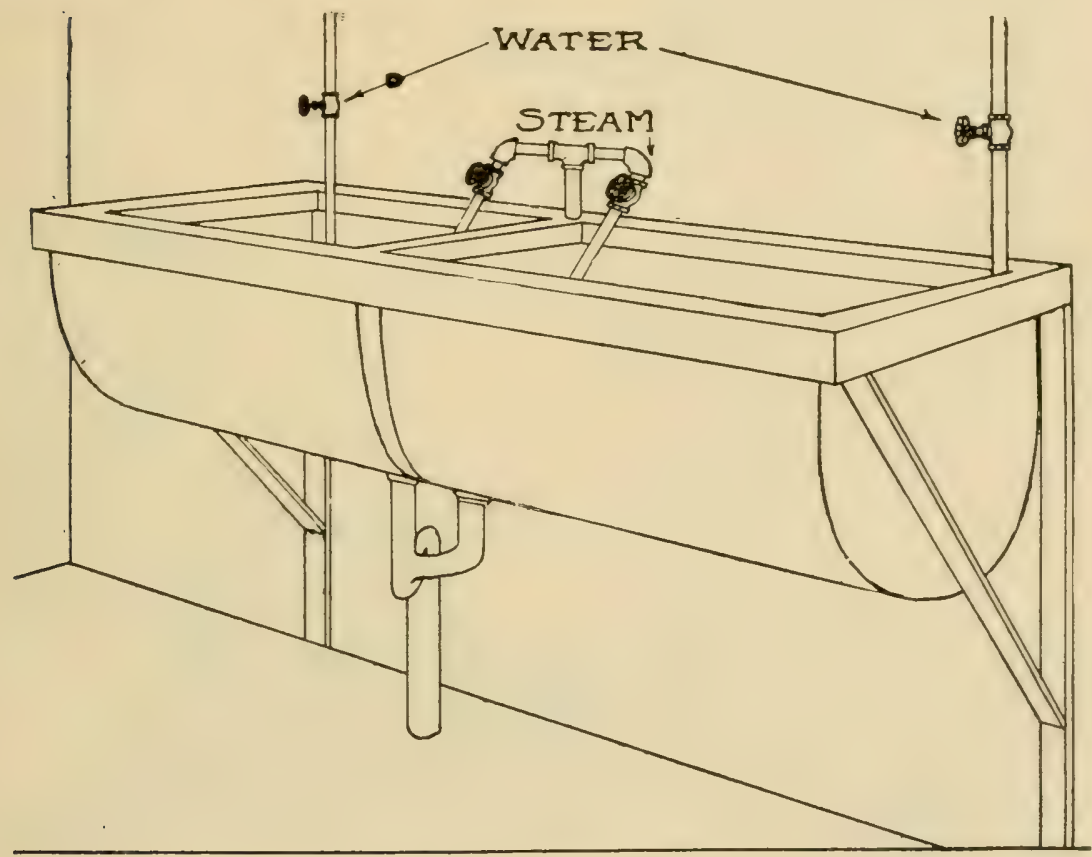

Fig. 77.--Wash Sinks.

for rinsing before washing, one for washing and one for final rinsing.

For convenience the wash sink should be thirty-six 
inches long, twelve inches deep, and sixteen inches wide. The bottom should be round and two feet from the floor. When closer to the floor than this too much stooping is required.

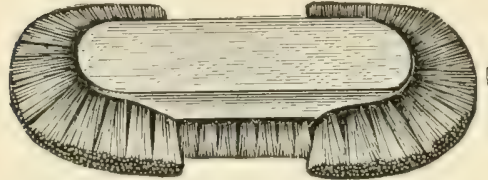

Fig. 78. - A Good Cleaning Brush.

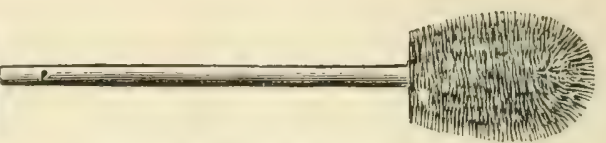

Fig. 79.-Milk Bottle Brush.

Galvanized iron furnishes one of the most suitable materials for the construction of wash sinks. They should be provided with steam (or hot water) and cold water pipes as shown in Fig. 77.

Method of Washing. All vessels should be thoroughly $r$ insed in warm water to remove small residues of milk and cream. The rinsing is followed by washing with moderately hot water to which a ha nd ful of some cleaning powder has bee $\mathrm{n}$ added. $\mathrm{Th}$ e washing should be done with brushes rather than cloths because the bristles enter into crevices which

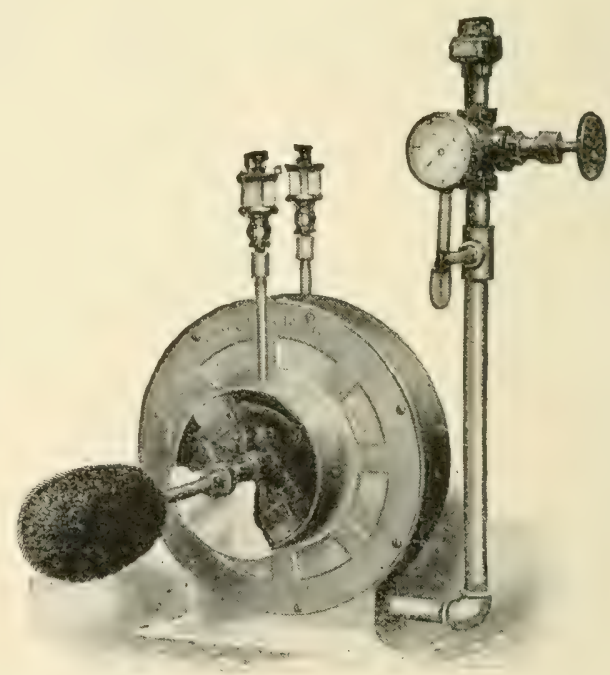

Fig. 80.-Bottle Washer. a cloth could not possibly reach. Finally rinse the vessels in clean water.

A bottle washer, like that shown in Fig. 8o, saves much 
labor and does very efficient work. The motive powe:may be either steam or water.

Sterilizing. Vessels that have been washed in the manner described above may look perfectly clean, but may still be far from being free from bacteria. These can be destroyed only by exposing the vessels to the boiling temperature for some time.

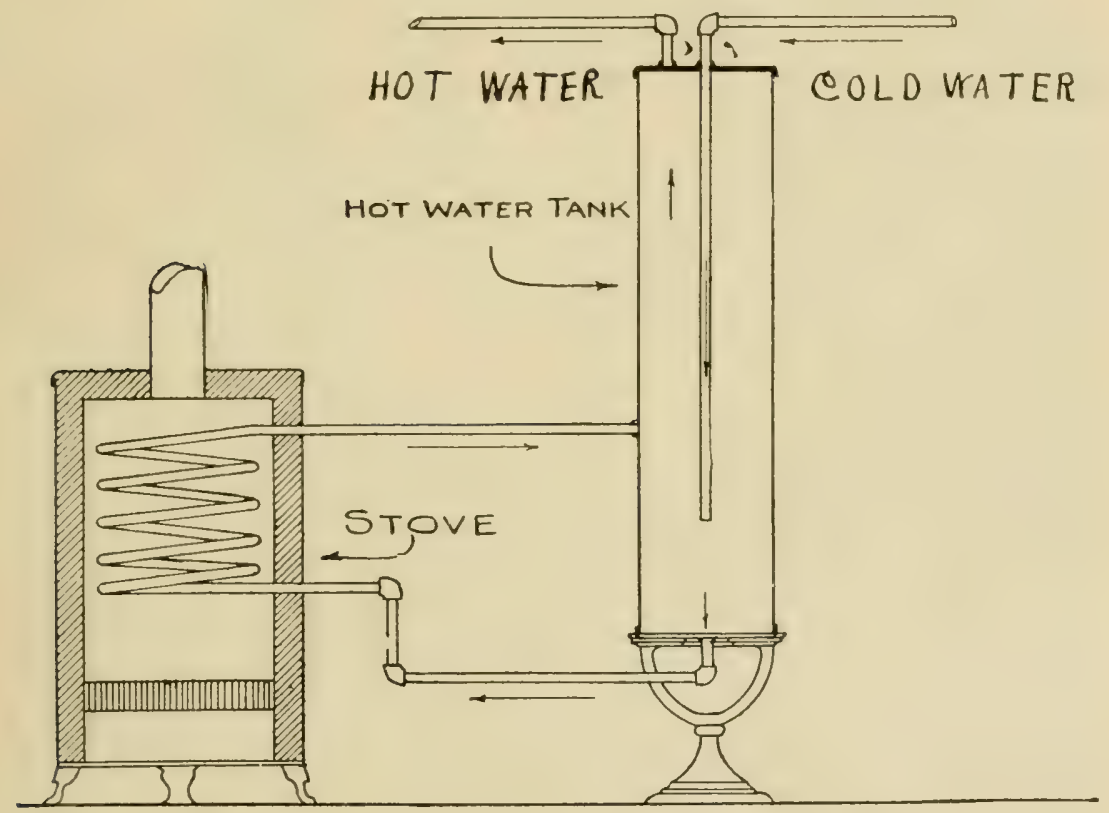

Fig. 81.-Cheap Arrangement for Securing Hot Water.

The simplest method of sterilizing is to place the vessels in boiling water for five minutes. This method commends itself especially to small dairymen who have no steam.

Where no steam is available, the best means of procuring hot water is the apparatus shown in Fig. 81.

The hot water tank is that commonly used in residences for heating water for the bath tub and can be obtained 


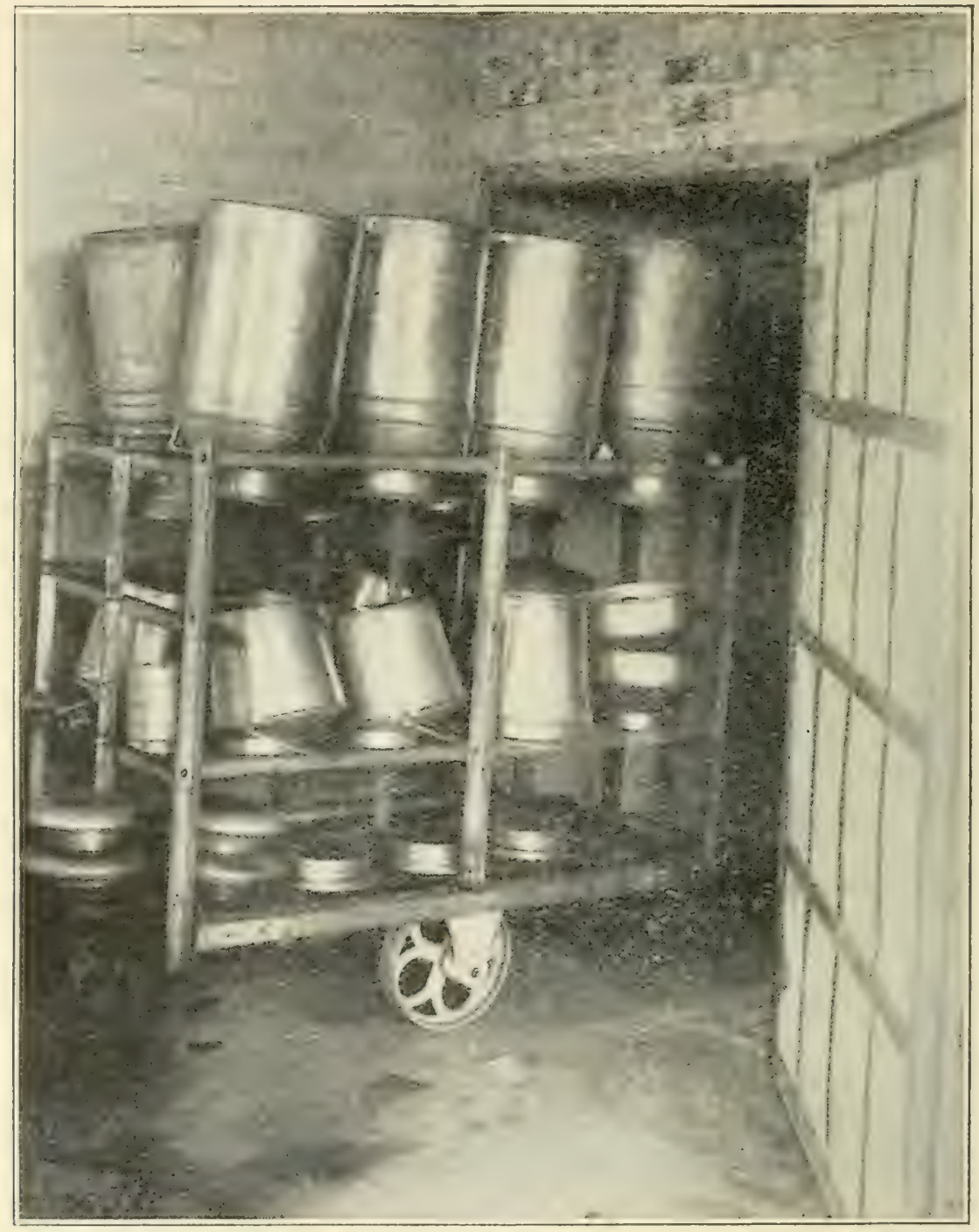

Fig. 82. -Sterilizing Truck and Front of Brick Sterilizer.

from plumbers for about $\$ 7.00$. Any stove in which iron coils can be heated will answer as a heater.

The best method of sterilizing is to place the vessels 
in a steam chamber of sufficient strength to withstand a pressure of ten or more pounds to the square inch. These sterilizers are usually constructed of concrete or brick and

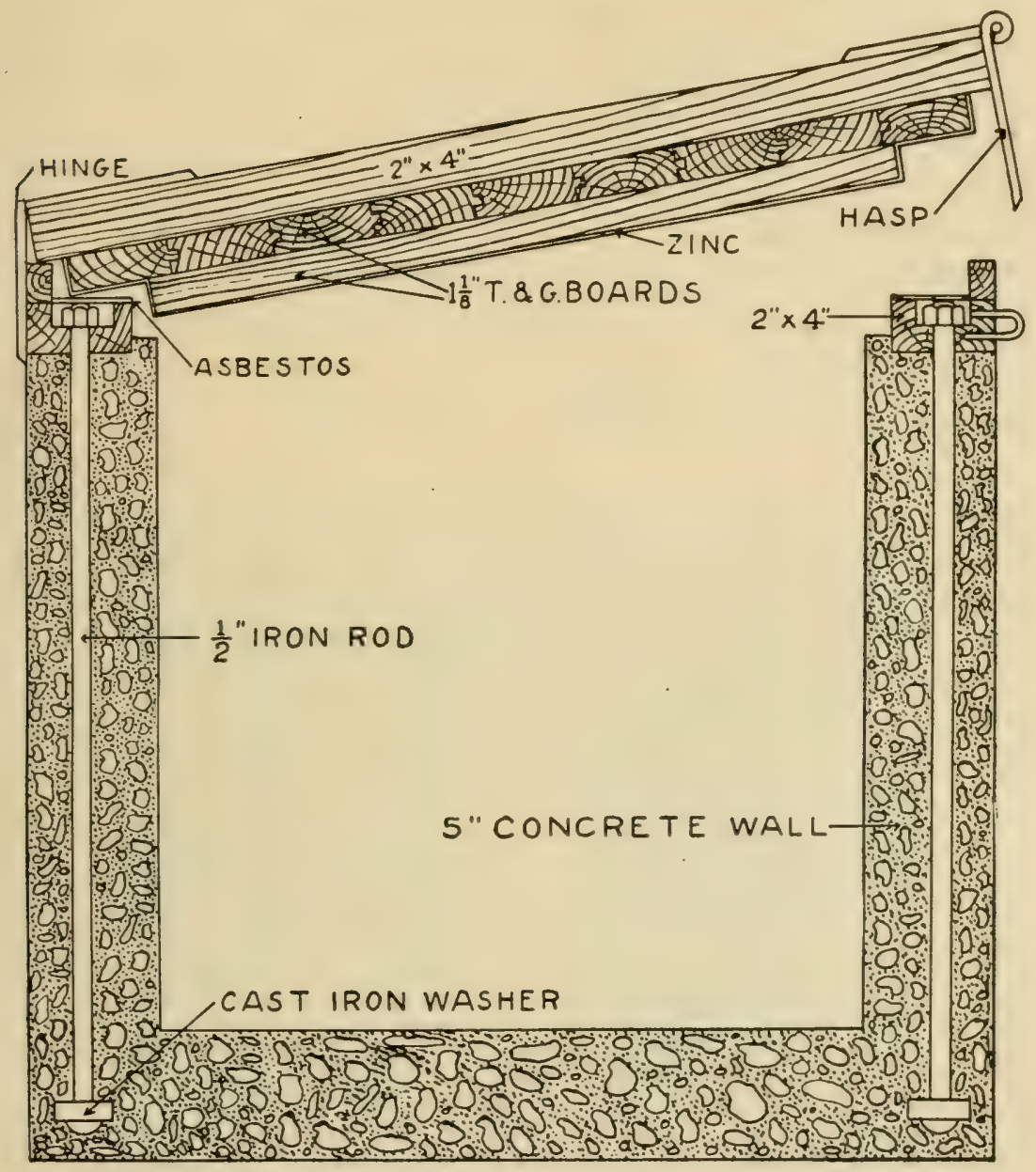

- Fig. 83.-Cross-Section of Concrete Sterilizer.

are provided with a heavy iron door which is large enough to admit a truck bearing the pails, cans, bottles, etc. Other sterilizers of this type are constructed of galvanized iron. The principal drawback to some of these sterilizers is 
their high cost, which renders their use by small dairymen almost prohibitive.

Cheap Sterilizers. A cross section through a cheap concrete sterilizer is shown in Fig. 83. It is essentially a rectangular concrete tank with a wooden cover which is lined with zinc. The sides and bottom are five inches thick and are brilt of concrete, which is made up of one part cement, two parts sand, and two parts coarse gravel. A thin coat, consisting of one part cement and two parts sand, is used as an inside finish.

Fig. 84 shows a common galvanized iron sterilizer which answers the purpose for small dairymen.

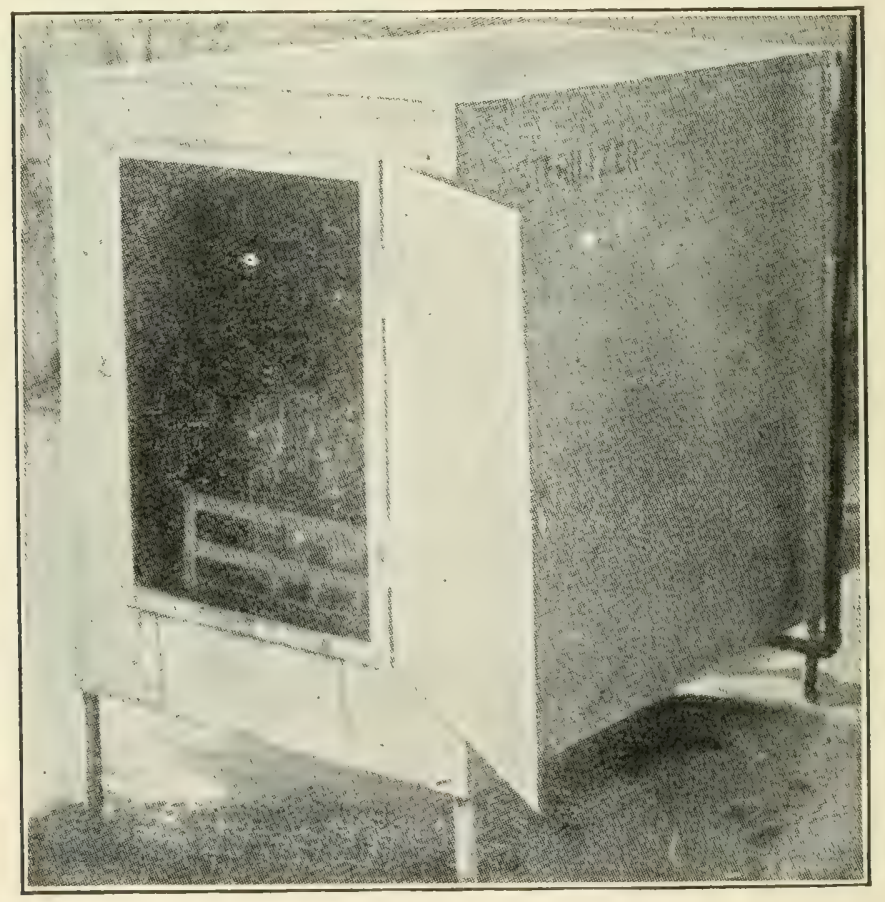

Fig. 84.-A Cheap Sterilizer. 


\section{CHAPTER XXXVI.}

KEEPING ACCOUNTS.

Various methods are followed in keeping accounts with patrons, but nearly all of them involve the use of tickets, route book, and some form of ledger. The method here described is recommended because of its simplicity.

Tickets. Most customers prefer to settle their milk and cream accounts daily. This they do by purchasing a quantity of tickets from the milkman and handing them out every time milk or cream is purchased.

The tickets should be used but once. Where they are repeatedly used they become dirty and a real source of danger. Passing from one household to another they are likely to become contaminated with disease germs and thus become the means of disseminating disease.

The coupon ticket presented on the next page is one of the most satisfactory in use at the present time. The portion of the ticket above the perforations is retained by the milkman. If the ticket is paid for at the time of purchase, this must be indicated on the stub retained by the dairyman as well as on the customer's ticket.

Coupon tickets are also used for cream and buttermilk. Tickets for different products should have different colors.

Tickets are not absolutely necessary ; indeed, many customers prefer to do without them. Where no tickets are 
270

DAIRY FARMING

No. $4 \mathrm{~s}^{-}$

Dato Lee. 2 10.8

Q. Eaton

$102 \ln 8 t$

TO TICKETS $\$ 1.00$.

MI L K.

Cr. 1.00

MI LI.

No.. $\angle S 5$

Dato Lee. 2 .1908

M. eaton

TO SPRING VALLEY DAIRY, Dr.

J. L. JONES, Prop., Middleton, N. Y.

TO TICKETS $\$ 1.00$.

Received Payment .

Date.

Lee. 2

L. fond 1908

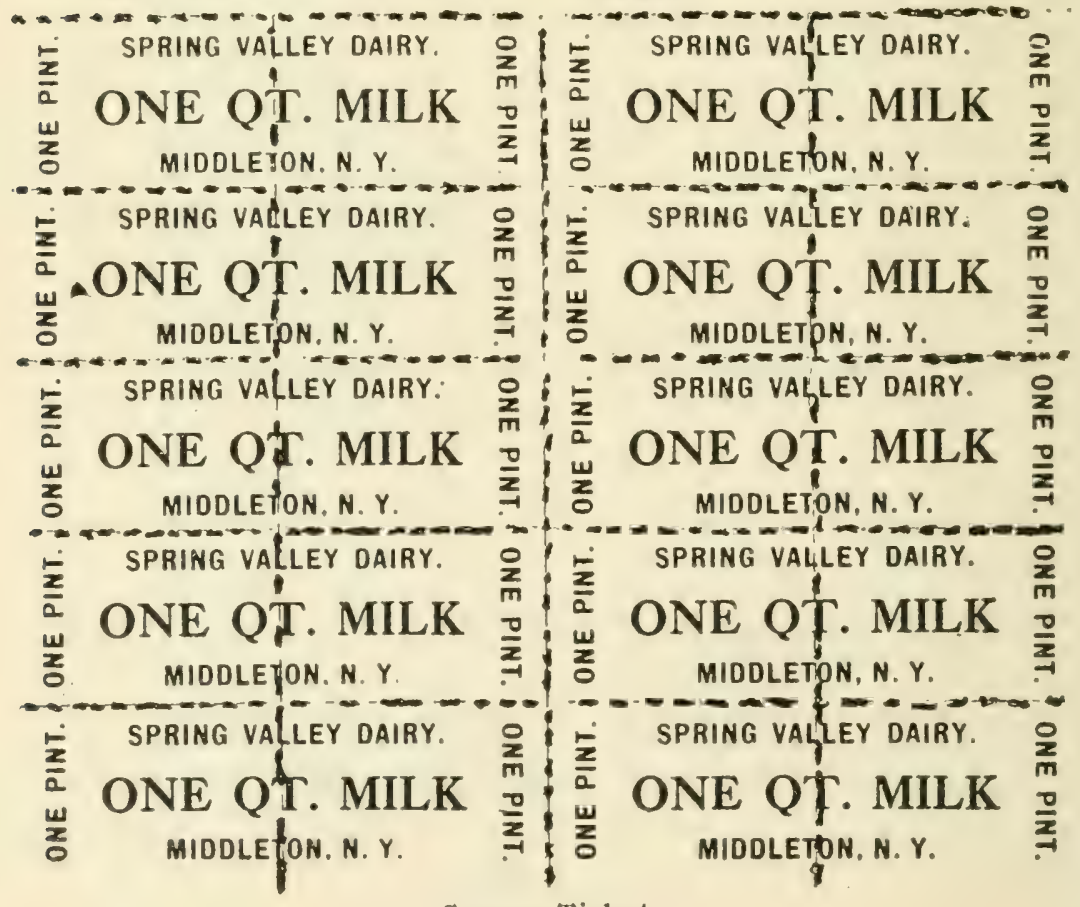

Coupon Ticket. 
used, an account is rendered at the end of the month similar to that rendered by the grocer.

Route Book. It is evident that if customers were always supplied with tickets and regularly paid for each delivery of milk or cream, no further record would be necessary. But customers will run out of tickets occasionally as well as forget to regularly hand them out, hence it is necessary for drivers to carry with them a record or route book in which each transaction is recorded at the time it is made. A form suitable for this purpose is shown below.

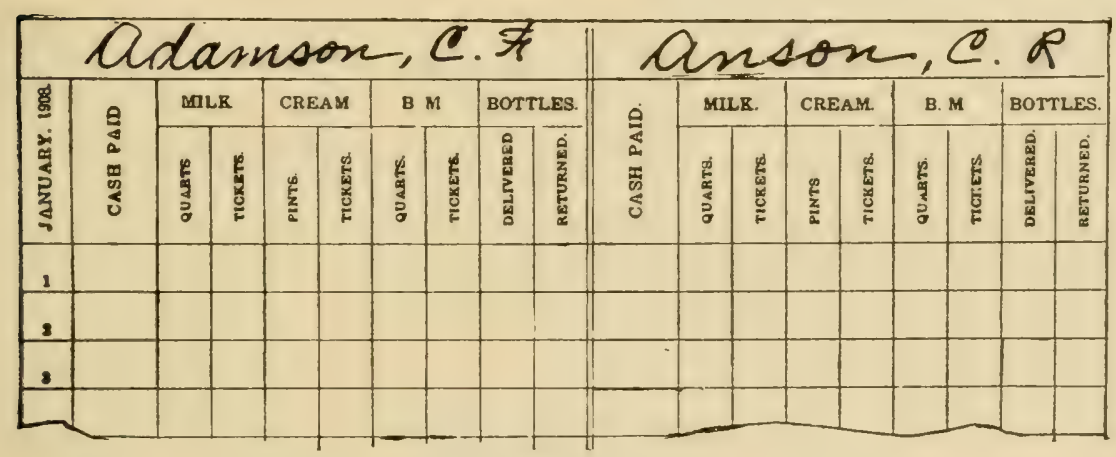

Form of Route Book.

The route book consists of loose leaves, upon which the names of customers are arranged alphabetically. The leaves are renewed each month, the old one being placed on file for future reference. The letters B. M. stand for buttermilk.

Ledger. As a rule all accounts are settled monthly. The ledger form shown below serves satisfactorily as a permanent monthly record.

On the debit side are recorded the sales and the total value of the tickets purchased. On the credit side are 
recorded all the receipts for the same period. The balance represents the difference between the debits and credits.

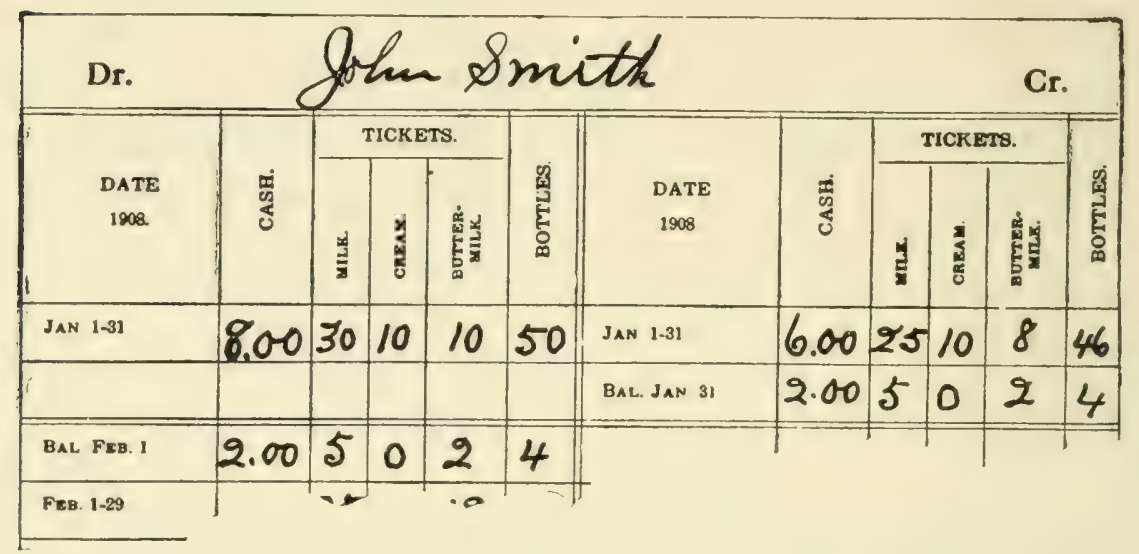

Forin of Ledger.

Monthly Statement. At the end of each month a statement should be rendered to customers showing their indebtedness. A form like that herewith shown answers the purpose satisfactorily.

SPRINGDALE SANITARY DAIRY,

J. S. HOONE. Proprlets

ve fohm Smid

REIDAVILLE, N. R.. Hech/_100.8

To SPRINGDALE SANITARY DAIRY, DR.

J C. BOONE。 Proprletor

\begin{tabular}{|c|c|c|c|c|c|}
\hline & Balance Fit.I & 2 & 50 & & \\
\hline Fef:1- 28 & 40 guarts milt \& 8 & 3 & 20 & & \\
\hline$n$ & 11 pinter cream 20 & 2 & 20 & & \\
\hline " & 5 quarts Luttermils of & & 25 & 8 & 15 \\
\hline$"$ & By cash & & & 6 & $\infty$ \\
\hline & ho. of unreturnes battles 8 & & & 2 & 15 \\
\hline
\end{tabular}

Monthly Statement. 
Order Book for Supplies. For convenience as well as for permanent record, all orders should be made in duplicate in a book specially made for the purpose. The leaves in the order book are alternately marked "original" and "duplicate," the duplicate being made at the same time as the original by using carbon paper between the two. A suitable form of order blank is shown below.

Original Springdale Sanitary Dairy.

J. C. Boone, Prop.

Order No. ....... Reidville, N. H. ......... I9o.. To

Dear Sir: Please deliver by........... the following:

Invoice and ship to

Springdale Sanitary Dairy,

J. C. Boone, Prop., Reidville, N. H. 


\section{CHAPTER XXXVII.}

WATER AND ICE SUPPLY.

WATER SUPPLY

Importance of Pure Water. A great deal of disease in farm homes is directly traceable to infected water. Typhoid fever especially is so frequently caused by polluted well water that physicians at once look to this as the probable cause wherever this disease is found to exist.

Where wells infected with disease germs happen to exist on dairy farms that supply milk to neighboring cities, disease is not limited to the dairyman's own family, but may be spread along the entire milk route. Many typhoid fever epidemics have been positively traced to milk which has become infected through water containing the disease germs. Nowhere is pure water so important, therefore, as upon dairy farms.

The disease germs usually find their way into the milk through milk vessels which have been washed with infected water. The use of such water for washing cows' udders previous to milking may also be the means of infecting the milk supply.

Location of Well. The most satisfactory location for the well is at the dairy house where the coldest water is required and where it will be most convenient. Here the water for both the dairy, the home, and the stock can be pumped with the dairy engine. Further, the well, like 
the dairy house, should stand on slightly elevated ground so as to insure drainage away from it.

Construction of Well. In a properly constructed well, no water should enter it except near the bottom. This compels the water to pass through a thickness of earth sufficient to purify it where the wells are of a reasonable depth.

Where there is no rock or hard clay and where the

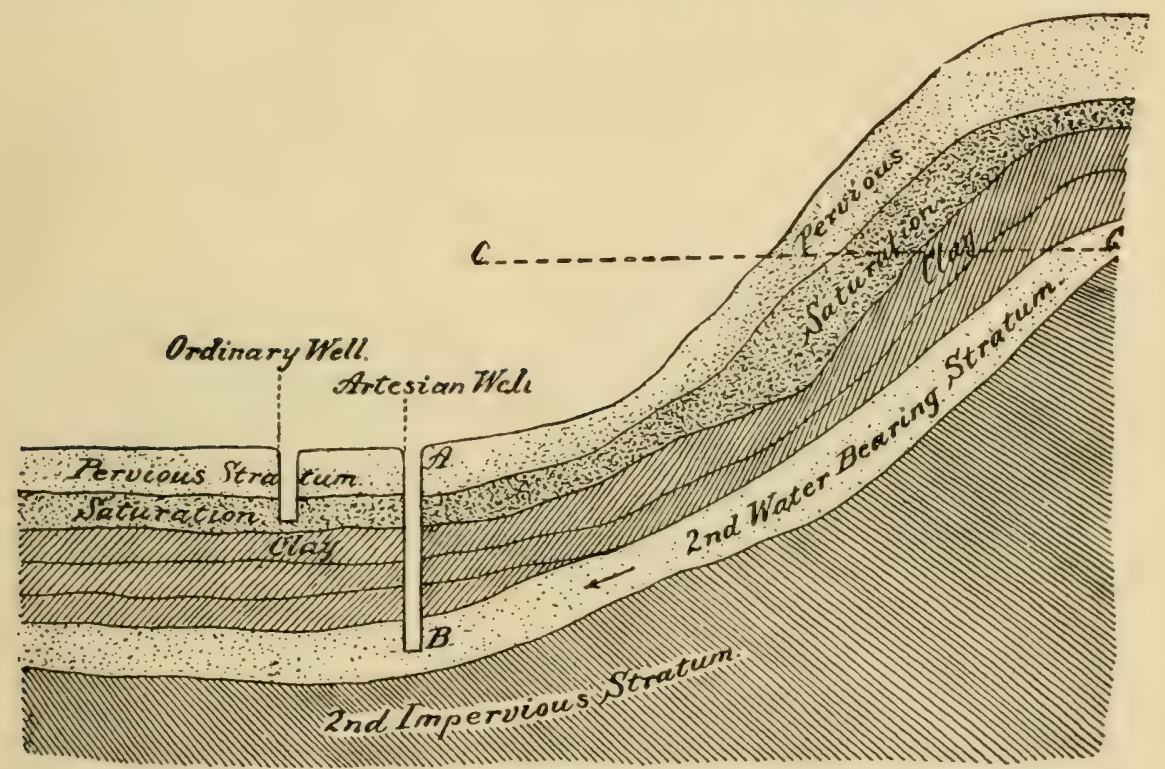

Fig. 85.-Soil Strata. (From Harrington's "Practical Hygiene.")

water can be had at a reasonable depth, the driven well, commonly known as the Abyssinian tube well, is the cheapest and one of the safest. This well is made by driving into the ground a water-tight iron tube, the lower end of which is pointed and perforated.

In case rocks and hard clay must be penetrated, or great depth must be reached to secure water, the bored or drilled well, piped from top to bottom with water-tight iron pipes, will be found most satisfactory. 
Water from the upper pervious stratum should be avoided wherever possible, even with wells of the kind just described. Especially is this necessary where the wells are shallow. The purest water is obtained by sinking the well through an impervious stratum, like that shown in Fig.85.

The most dangerous well is the common dug well with pervious walls and so located as to permit seepage into it from outhouses, barnyards and cesspools. Wells of this type are altogether too common on dairy farms.

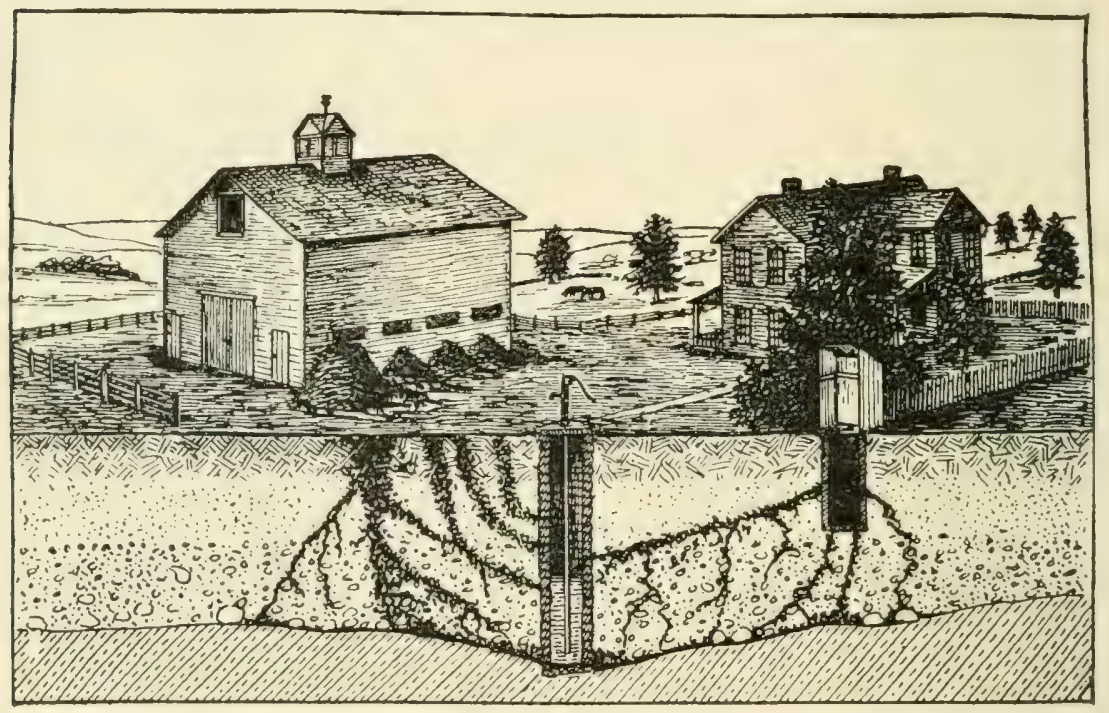

Fig. 86.-Sources of Well Water Contamination. (From Bul. 143 Kan. Exp. Sta.)

All wells, whatever their construction, must be provided with water-tight metallic or concrete covers to prevent the entrance of impurities into the shaft.

ICE SUPPI,Y.

Necessity of Ice. Where there is no equipment for 
mechanical refrigeration, ice is indispensible in furnishing the best quality of milk and cream. A low enough temperature cannot be secured with water alone, neither can the cooling be accomplished as quickly as is desirable for best results. Furthermore, a satisfactory cold storage cannot be had without the use of ice.

Cooling Power of Ice. A great deal of cooling can be done with a comparatively small amount of ice. This is due to the latent or "hidden" cold in ice. Thus to convert one pound of ice at $32^{\circ} \mathrm{F}$. into water at the same temperature requires 142 units of heat, or, in other words, enough cold is given out to reduce the temperature of I4 2 pounds of water one degree Fahr.

Construction of Ice House. To keep ice satisfactorily three things are necessary, (I) good drainage at the bottom, (2) good insulation, and (3) abundant ventilation at the top.

Good drainage and insulation at the bottom can be sesured by laying an eight-inch foundation of stones and gravel and on top of this six inches of cinders, the whole being underlaid with drain tile. One foot of sawdust should be packed upon the cinders and the ice laid directly upon the sawdust.

Satisfactory walls are secured by using matched boards on the outside of the studs and common rough boards on the inside, leaving the space between the studs empty. The ice should be separated from the walls by one foot of sawdust.

Where no solid foundation walls are provided, earth must be banked around the ice house to prevent the entrance of air along the base.

The space between the sawdust covering on top of the ice and the roof should be left clear. Openings in the 
gable ends as well as one or two ventilating shafts projecting through the roof should be provided to insure a free circulation of air under the roof. This will not only remove the hot air which naturally gathers beneath the roof, but will aid in drying the sawdust.

The ice must be packed solidly, using no sawdust except at the sides and bottom of the ice house and on top of the ice when the filling is completed. At least one foot of sawdust must be packed on top of the ice.

Size of Ice House. The size of the ice house will depend, of course, upon the amount of ice to be used. For a herd of 25 cows, in the North, an ice house IO feet square by I4 feet high will usually answer. These dimensions provide storage for 22 tons of ice, allowing one-foot space all around the ice for sawdust. In the South about 50\% more ice is required than in the North.

In calculating the amount of storage space needed for ice, it is necessary to know that one cubic foot of ice at $32^{\circ}$ F. weighs 57.5 pounds.

As a matter of convenience in filling and emptying the ice house, doors should be provided in sections from the sill to the gable at one end of the building.

General Uses of Ice. Aside from the use of ice in cooling milk and cream, it can be employed to good advantage in several other ways. Its value in the household, in preserving meats, vegetables, and fruits cannot be overestimated. And what is so refreshing as cold drinks and frozen desserts during the sumnier months! Ice is also frequently necessary in case of sickness.

Cost of Making Ice. Where ice can be obtained within a reasonable distance, the cost of cutting, hauling, and packing should not exceed \$I.5O per ton.

Source of Ice. Always select the cleanest ice available. 
Where the source of ice is at too great a distance from the dairy, an artificial pond should be made upon ground with a reasonably impervious subsoil and with a natural concave formation. If such a piece of ground is flooded with water during the colfest weather, an ample supply of ice will be available in a very short time. 


\section{CHAPTER XXXVIII.}

DAIRY BY-PRODUC'TS.

COMPOSITION OF BY-PRODUC'TS.

\begin{tabular}{|c|c|c|c|c|c|}
\hline & $\begin{array}{l}\text { Water. } \\
\text { Per Cent. }\end{array}$ & $\begin{array}{c}\text { Fat. } \\
\text { Pe: Cent. }\end{array}$ & $\begin{array}{c}\text { Milk Sugar, } \\
\text { Per Cent. }\end{array}$ & $\begin{array}{c}\text { Casein and } \\
\text { Albumen, } \\
\text { Per Cent. }\end{array}$ & $\begin{array}{c}\text { Ash. } \\
\text { Per Cent. }\end{array}$ \\
\hline Skim-milk........... & 90.50 & 0.10 & 4.95 & $3 \cdot 57$ & 0.78 \\
\hline Buttermilk . . . . . . . . . & 90.39 & 0.50 & 4.06 & 3.60 & 0.75 \\
\hline Whey .............. & 93.10 & 0.30 & $5 \cdot 15$ & 0.80 & 0.65 \\
\hline
\end{tabular}

Skim=Milk as a Feed. This is a question in which dairymen should take greater interest because, as a rule, the feeding value of skim-milk is underestimated. Feeding trials show that five pounds of skim-milk are equal to about one pound of grain (corn, barley, oats). They also show that on an average four pounds of grain will produce one pound of gain with young pigs, while five pounds will produce the same gain with pigs from six to twelve months old. On this basis twenty pounds of skim-milk are required to produce one pound of gain with young pigs and twenty-five pounds with older pigs. With pork at eight cents a pound, one hundred pounds of skim-milk will produce 40 cents worth of pork with young pigs and 32 cents worth with older ones.

The amount of skim-milk required to produce a pound of veal is shown by feeding trials to range on an average from fifteen to twenty pounds. 'Taking the latter figure 
and valuing veal at 7 cents a pound, skim-milk is worth 35 cents per Ioo pounds for veal production.

The highest returns from the feeding of skim-milk are secured when fed to poultry. Careful experimental tests show that as high as 75 cents per Ioo pounds may be realized for skim-milk when fed to poultry

Skim=milk as a Fertilizer. Many who are selling the skim-milk off the farm do not sufficiently appreciate the fertilizing value of this material. At the lowest estimate skim-milk has a fertilizing value of ten cents per hundred pounds.

Buttermilk as a Feed. Buttermilk has essentially the same composition as skim-milk. It contains a little more fat, but less sugar, part of which has been changed into lactic acid. For pig feeding, except in the case of very young pigs, it has practically the same feeding value as skim-milk, as shown by numerous feeding experiments. It is also a good poultry feed. It can not be recommended, however, for calf feeding, though it has been used with fair success in some instances.

Whey as a Feed. Whey when properly cared for has practically one-half the feeding value of skim-milk. 


\section{CHAPTER XXXIX.}

\section{MACHINE MILKING.}

Recent results secured by experiment stations and nunerous large dairymen indlicate that the milking machine may become an important factor in future dairying. The testimonials from these sources show that machines milk quite as satisfactorily as average hand milkers; and since one attendant can milk four to six cows at the same time, there is a material saving in labor, besides making labor more agreeable. Nany, however, have pronounced machine milking unsatisfactory.

Principle of Operation. Milking by machine is accomplished by suction similar to that produced by a sucking calf. The suction is intermittent and is created by producing a partial vacuum in a system of pipes to which the milking machines are attached during milking.

Apparatus. The necessary apparatus for machine milking consists of a milker,

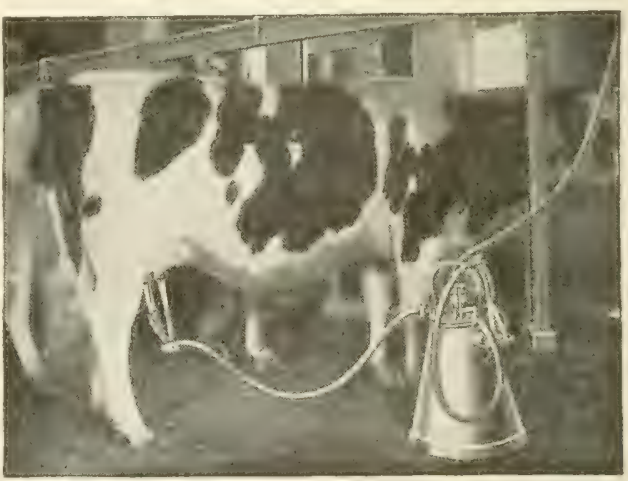

Fig. 87.-Milking Machine in operation. which includes a tin pail, teat cups, etc.; a vacuum pump; some form of power; a vacuum reservoir; two vacuum gauges; a safety 
valve; and about 50 feet of gas pipes. Each machine milks two cows.

Cost of Apparatus. The following may be considered an approximate estimate of the cost of a milking outfit for about 30 cows: Two milliers, $\$ 180$; vacuum pump, $\$ 50$; vacuum reservoir, including two vacuum gauges and a safety valve, \$35; a two horse power gasoline engine, $\$ 85$; and pipes and piping, $\$ 50$; The cost of pipes depends largely upon the distance of the power from the barn. It is not necessary to have the power in the barn or even near it. (See Chapter on Farm Power.)

operating Machine. When ready to begin milking start the vacuum pump and place a milker between two cows and open valve on main vacuum pipe. Bend over teat cups and attach one by one to one cow and then proceed to do the same with the other. Similarly attach one or two more milkers, so as to keep four to six cows milking at the same time. A short glass tube at the machine shows when the milking is completed.

The mouthpieces on the teat cups must be of a size to correspond with the size of the teats. They must be neither too small nor too large. It is important, also, that the piping system be kept air tight and free from moisture.

Details concerning the installation and operation of the machines may be had for the asking by writing to the manufacturers. 


\section{CHAPTER XL.}

PASTEURIZATION OF MILK AND CREAM.

The process known as pasteurization derives its name from the eminent French scientist Pasteur. It consists in heating and cooling milk and cream in a manner which will destroy the bulk of bacteria in them, but which will leave their chemical and physical properties unchanged as far as possible.

Advantages of Pasteurization: The advantages to be derived from pasteurization vary with the conditions under which the milk is produced and the efficiency with which the work is conducted. If the milk comes from dairies where disease and uncleanliness prevail, pasteurization will prolong the keeping quality of the milk and also materially lessen the danger from disease germs. If, on the other hand, healthfulness and cleanliness receive the exacting attention which prevails on certified dairy farms, nothing can be gained by subjecting milk to the pasteurizating process.

Disadvantages of Pasteurization. The principal disadvantages are as follows: (I) the cost of pasteurizing apparatus; (2) the cost of pasteurizing; (3) the tendency to promote uncleanliness on the part of the producer; (4) the tendency to reduce the cream line on the milk; (5) lessening of the whipping property of the cream; and (6) the tendency to impart a "cooked" flavor to the milk and cream.

Methods of Pasteurization. Two general methods 
are now in vogue: (I) the discontinuous method by which every particle of milk and cream is heated from ten to thirty minutes according as the temperature is high or low; (2) the continuous method by which milk and cream are permitted to pass in a constant stream through the pasteurizer and are subjected on an average less than one minute to the pasteurizing temperature.

In general the most efficient pasteurization is obtained with the discontinuous method.

Pasteurizing Temperatures. Obviously where milk is heated only a minute or less, a higher temperature must be employed than where it is heated for a much longer period of time. With the continuous method the temperature varies from $160^{\circ}$ to $180^{\circ} \mathrm{F}$. With the discontinuous method the temperature varies from $140^{\circ}$ to $I 55^{\circ} \mathrm{F}$. Exposing milk or cream to a temperature of $145^{\circ} \mathrm{F}$. for twenty minutes results in very satisfactory pasteurization. The temperature and time of exposure should always be such as to insure the destruction of the tubercle bacillus, which is one of the most resistant of the disease bacteria most commonly found in milk.

Quick Cooling. In pasteurizing the heating must be quickly followed by thorough cooling. This is an extremely important part of the pasteurizing process. It is desirable that the temperature be reduced at once to $45^{\circ}$ F. or below.

Viscogin. Thorough pasteurization reduces the viscosity or whipping property of cream. To restore the original viscosity a solution of sucrate of lime is added, which is known as viscogin. This solution is made by adding an excess of slaked lime to three parts of sugar dissolved in five parts of water. The mixture is al- 
lowed to stand twenty-four hours, after which the clear licuid at the top is poured from the sediment and preserved in a stoppered bottle.

Add one part viscogin to about I5O parts of cream. Never add so much as to render the cream alkaline.

While viscogin is entirely harmless, it is nevertheless an adulterant and cream treated with it must be so labeled.

Inefficient Pasteurization. Milk that has been underheated is more dangerous than that which has not been heated at all. The reason for this is that inadequate heat in pasteurizing may destroy the lactic acid bacteria (which are easily killed) and by so doing actually better the conditions for the growth of the more resistant and obnoxious kinds. Lactic acid organ'sms are antagonistic to other classes of bacteria and are therefore a real safeguard to milk. This makes it plain that unless milk is pasteurized at a temperature which will destroy the pathogenic and non-acid bacteria as well as the acid bacteria, it is far better not to heat it at all.

Pasteurization should be condemned where its only object is to keep milk sweet. Its real object should be to destroy all actively growing bacteria and especially all disease-producing organisms such as the tubercle bacillus which is among the most resistant.

Pasteurizing in the Home. If milk must be pasteurized to render it safe, there is no better place to do this than in the home where it is to be consumed. The pasteurizing is very easily and satisfactorily accomplished by the use of a small double milk or rice boiler which can be procured for about one dollar from hardware dealers everywhere. It is essential to stir the milk while heating and to use a reliable thermometer. 


\section{APPENDIX.}

Period of Gestation. This refers to the time which elapses between conception and calving. The average period of gestation of a cow is 283 days.

Frequency of Heat. As a rule non-pregnant cows will come in heat every 2I days. The period of heat lasts from 2 to 3 days.

Metric System of Weights and Measures. This system was devised by the French people and has very. extensive application wherever accuracy in weights and measures is desired. Some of its equivalents in ordinary weights and measures are given in the following table:

\begin{tabular}{|c|c|}
\hline Ordinary weights and measures. & Equivalents in metric system. \\
\hline $\begin{array}{l}1 \text { ounce }(a v) \\
1 \\
1 \\
1 \\
1\end{array}$ & $\begin{array}{l}2835 \text { grams. } \\
09464 \text { liter. } \\
3.7854 \text { liters. } \\
29.57 \text { cubic centimeters (c.c.) } \\
0.4536 \text { kilogram. } \\
64.8 \text { milligrams. } \\
254 \text { centimeters. } \\
0.3048 \text { meter. }\end{array}$ \\
\hline
\end{tabular}

ADDRESSES OF DAIRY CATTLE BREEDERS' ASSOCIATIONS.

\begin{tabular}{|c|c|c|}
\hline Breed. & Secretary. & Postoffice. \\
\hline $\begin{array}{l}\text { Jersey } . . . . . . . . . . . . \\
\text { Guernsey............... } \\
\text { Hulstein-Eriesian...... } \\
\text { A yrshire ................ }\end{array}$ & $\begin{array}{l}\text { J. J. Hemingway....... } \\
\text { Wm. H. Caldwell ...... } \\
\text { F. L. Houghton......... } \\
\text { C. M. Winslow......... }\end{array}$ & $\begin{array}{l}8 \mathrm{WV} .17 \text { th st., New York, } \\
\text { N. Y. } \\
\text { Peterboro, N. H. } \\
\text { Brattleboro, Vt. } \\
\text { Branden, Vt. }\end{array}$ \\
\hline
\end{tabular}


Rations According to Yield of Milk. The Connecticut (Storrs) standard rations for varying yields of milk are shown in the following table:

TABLE-FEEDING STANDARDS.

\begin{tabular}{|c|c|c|c|c|c|c|}
\hline \multirow{3}{*}{$\begin{array}{l}\text { When giving } \\
\text { daily. }\end{array}$} & \multirow{3}{*}{$\begin{array}{l}\text { Live } \\
\text { weight, } \\
\text { pounds. }\end{array}$} & \multicolumn{5}{|c|}{ Daily, per 1,000 pounds of live weight. } \\
\hline & & \multirow{2}{*}{$\begin{array}{l}\text { Total } \\
\text { dry mat- } \\
\text { ter, } \\
\text { pounds. }\end{array}$} & \multicolumn{3}{|c|}{ Digestible nutrients, pounds. } & \multirow[b]{2}{*}{$\begin{array}{l}\text { Nutritive } \\
\text { ratio. }\end{array}$} \\
\hline & & & Protein. & $\begin{array}{l}\text { Carbohy. } \\
\text { drates. }\end{array}$ & Fat. & \\
\hline 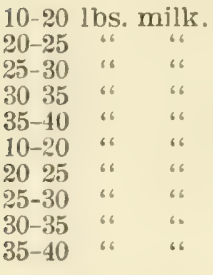 & $\begin{array}{l}700-950 \\
700-950 \\
700950 \\
700-950 \\
700950 \\
950-1100 \\
950-1100 \\
950-1100 \\
950-1100 \\
950-1100\end{array}$ & $\begin{array}{l}2022 \\
21-23 \\
21-23 \\
22-24 \\
22-24 \\
22-24 \\
22 \quad 25 \\
2325 \\
2426 \\
2426\end{array}$ & $\begin{array}{ll}2 & 0 \\
2 & 3 \\
2.6 \\
2.9 \\
3.9 \\
2.3 \\
2.6 \\
2.9 \\
3.2 \\
3.5\end{array}$ & $\begin{array}{l}1012 \\
10-12 \\
1012 \\
11-13 \\
11-13 \\
12-14 \\
12-14 \\
12-14 \\
1315 \\
13-15\end{array}$ & $\begin{array}{l}0.3-0.5 \\
0.40 .6 \\
0.4-0.6 \\
0.5-0.7 \\
0.5-0.7 \\
0.4-0.6 \\
0.5-0.7 \\
0.5-0.7 \\
0.6-0.8 \\
0.6-0.8\end{array}$ & $\begin{array}{l}1: 6.0 \\
1: 5.3 \\
1: 4.7 \\
1: 4.6 \\
1: 4.2 \\
1: 6.1 \\
1: 5.5 \\
1: 5.0 \\
1: 49 \\
1: 4.4\end{array}$ \\
\hline
\end{tabular}

Scale of Points for Judging Butter. Butter is judged commercially on the basis of 45 points for flavor, 25 for texture, I 5 for color, Io for salt, and 5 for package, total Ioo.

Scale of Points for Judging Cheese. Cheese, as a rule, is judged commercially on the basis of 45 points for flavor, 30 for texture, Io for salt, Io for color, and 5 for appearance, total Ioo.

Milk Solids. The solids of milk include everything but the water. If a sample of milk be kept at the boiling temperature until all the water is evaporated, the dry, solid residue that remains constitutes the solids of milk. It is convenient to divide the solids into two classes, one including all the fat, the other all the solicls which are not fat. In referring, therefore, to the different solids of milk, we speak of the "fat" and the "solids-not-fat" which, together, constitute the "total solids." 
Relationship of Fat and Solids=not=Fat. In normal milk a fairly definite relationship exists between the fat and the solids-not-fat. For example, milk rich in fat is likewise rich in solids-not-fat. On the other hand, milk poor in fat is also poor in solids-not-fat. Hence the justice of paying for milk, delivered to cheese factories, on the butterfat basis. See table on page I33.

Composition of Cream. Crean contains all the constituents found in milk, though not in the same proportion. The fat may vary from $8 \%$ to $68 \%$. As the cream grows richer in fat it becomes poorer in solids-not-fat. Richmond reports the following analysis of a thick cream:

Per cent.

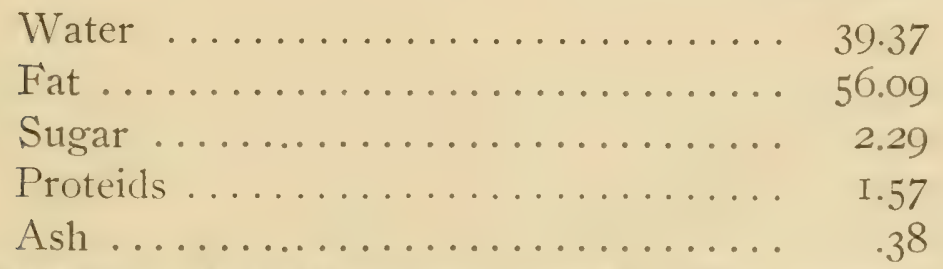

Capacity of Cylindrical Siloes. The approximate capacity of cylindrical siloes for well-matured corn silage is shown in the following table:

'TABLE-CAPACITY OF CYLINDRICAL SILOES, TONS。*

\begin{tabular}{|c|c|c|c|c|c|c|c|c|c|c|c|c|c|}
\hline \multirow[b]{2}{*}{ Depth of silo, feet. } & \multicolumn{13}{|c|}{ Inside diameter of silo, feet. } \\
\hline & 10 & 12 & 14 & 15 & 16 & 18 & 20 & 21 & 22 & 23 & $2 t$ & 25 & 26 \\
\hline & 26 & 38 & 51 & 59 & 67 & 85 & 105 & 115 & 127 & 138 & 151 & 163 & $17 \%$ \\
\hline & 28 & 40 & 5.5 & 63 & 72 & 91 & 112 & 123 & 13. & 148 & 161 & 175 & 189 \\
\hline & 30 & 43 & 59 & 67 & 77 & 97 & 120 & 132 & 145 & 158 & $1 \% 2$ & 187 & 202 \\
\hline & 32 & 46 & 62 & 72 & 82 & 103 & 128 & 141 & 154 & 169 & 184 & 199 & 216 \\
\hline & 34 & 49 & 66 & 76 & 87 & 110 & 135 & 149 & 161 & 179 & 195 & 212 & 229 \\
\hline & 36 & 52 & 70 & 81 & 90 & 116 & 143 & 158 & 173 & 190 & 206 & 224 & 242 \\
\hline & 38 & 55 & 74 & 85 & 97 & 123 & 152 & 16 & 184 & 201 & 219 & 237 & 257 \\
\hline & 40 & 5 & 78 & 90 & 103 & 130 & 160 & 177 & 194 & 212 & 231 & 251 & 271 \\
\hline & 42 & 61 & 83 & 95 & 108 & $13 \pi$ & 169 & 186 & 204 & 223 & 243 & 264 & 285 \\
\hline & 45 & 64 & 88 & 100 & 114 & 144 & 178 & 196 & 215 & 235 & 265 & 278 & 300 \\
\hline & 47 & 68 & 93 & 105 & 119 & 151 & 187 & $206^{\circ}$ & 226 & 247 & 269 & 292 & 315 \\
\hline & 49 & 70 & 96 & 110 & 125 & 158 & 195 & 215 & 236 & 258 & 282 & 305 & 330 \\
\hline & 51 & 73 & 101 & 115 & 131 & 166 & 205 & 226 & 248 & 271 & 295 & 320 & 346 \\
\hline
\end{tabular}

*From Modern Silage Methods. 
Pasteurization of Milk. Where no ice is available, the keeping quality of milk may be materially prolonged by a process of heating and cooling known as pasteurization. This process consists in exposing milk to a temperature of about I 50 degrees $\mathrm{F}$. for thirty minutes, after which it is immediately cooled to the lowest temperature possible with water. 'This treatment destroys practically all of the bacteria in milk and thus not only materially increases its keeping quality, but also renders it free from harmful or disease-producing bacteria.

Definition of Technical Terms. A list of technical terms not specially defined in the text is presented below:

Albumenoids.-Substances rich in albumen, like the white of an egg, which is nearly pure albumen.

ANAEROBIC.-Living without free oxygen.

CENTRIFUGAL ForCE.-That force by which a body moving in a curve tends to fly off from the axis of motion. Chemical, Composition.-This refers to the elements or substances of which a body is composed.

Colmoidal.-Resembling glue or jelly.

Concussion.- The act of shaking or agitating.

Cubic Centitineter (c. c.).- See metric system p. 203.

EMULSION.-A mixture of oil (fat) and water containing sugar or some mucilaginous substance.

ENZYMES.-Unorganized ferments, or ferments that do not possess life.

FIBRIN.-A substance which at ordinary temperatures forms a fine network through milk which impedes the rising of the fat globules.

FOREMILK.-The first few streans of milk drawn from each teat. 
G.ILACTASE.-An unorganized ferment in milk which digests casein.

Mammary GLAND.-The organ which secrets milk.

MENiscus.-A body curved like a first quarter moon.

MiI,K SERUM.-Milk free from fat. Thus, skim-milk is nearly pure milk serum.

NEUT'RAL.-Possessing neither acid nor alkaline properties.

Non-CONDUCTOR.-A material which does not conduct heat or cold, or only so with great difficulty.

Osmosis.--The tendency in fluids to diffuse or pass through membranes.

RENNET EXTRACT.--The curdling and digesting principle of calf stomach.

SECRETION. - The act of separating or producing from the blood by the vital economy.

SPECIFIC Gr.lrity.-The weight of one body as compared with an equal volume of some other body taken as a standard.

SPORE.-The resting or non-vegetative stage of certain kinds of bacteria.

STERILIZATION.-The process of destroying all germ life by the application of heat near $212^{\circ} \mathrm{F}$.

STRIPPERS' MiLK.-The milk from cows far advanced in the period of lactation.

STrippings.-The last few streams of milk drawn from each teat.

Suspexsion.-The state of being held mechanically in a liquid, like butter fat in milk.

Tuberculin.- A sterile glycerine extract of the growth products of the tubercule bacillus.

VACUUM.-Space devoid of air.

VEGETATIVE, BACTERIA.-Those bacteria that are in an actively growing condition. 


\section{8\% of the World's}

DE
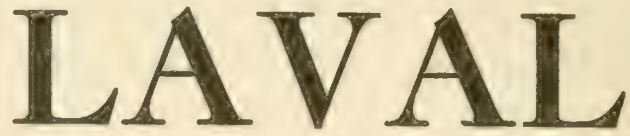

CREAM

SEPARATORS

Ten years ago there were a dozen different makes of creamery or factory separators in use. Today over 98 per cent of the world's creameries use DE LAVAL separators exclusively.

It means a difference of several thousand dollars a year whether a DE LAVAL

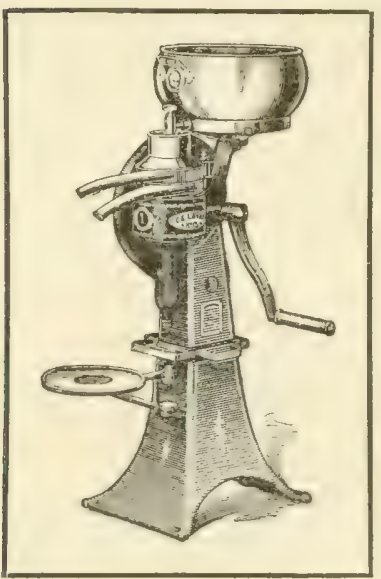
or some other make of separator is used in a creamery.

Exactly the same differences exist, on a smaller scale, in the use of farm separators. Owing to the fact, however, that most farm users do not keep as accurate records as the creameryman, they do not appreciate just what the difference between a good and a poor separator means to them in dollars and cents. Nine times out of ten the farmer can't tell whether or not he is wasting $\$ 50$ or $\$ 100$ a year in quantity and quality of product through the use of an inferior cream separator.

If you were in need of legal advice, you would go to a lawyer. If you were sick you would consult a doctor. If you had the toothache you would see a dentist. Why? Because these men are all specialists in their line, and you rely upon their judgment and skill. When it comes to buying a separator why not profit by the experience of the creameryman? His experience qualifies him to advise you correctly. He knows which separator will give you the best service and be the most economical for you to buy. That's why 98 per cent of the world's creameries use the DE LAVAL exclusively.

There can be no better recommendation for the DE LAVAL cream separator than the fact that the men who make the separation of milk a business use the DE LAVAL to the practical exclusion of all other makes.

\section{THE DE LAVAL SEPARATOR CO.}

165 Broadway

NEW YORK

173-177 William Street

MONTREAL
29 E. Madison Street CHICAGO

14 \& 16 Princess Street WINNIPEG
Drumm \& Sacramento Sts. SAN FRANCISCO

1016 Western Avenue SEATTLE 


\section{INDEX.}

\begin{tabular}{|c|c|}
\hline \\
\hline & \\
\hline 1, measures. & 39 \\
\hline , test $\ldots$. & \\
\hline birth, retention of.......11 & \\
\hline nts of cattle............ & \\
\hline$\ldots 16$ & \\
\hline lbumen of milk......... & \\
\hline Ifalfa $\ldots \ldots \ldots \ldots \ldots$ & \\
\hline mmonia fixers $\ldots \ldots \ldots$ & \\
\hline ppendix $\quad \ldots \ldots \ldots \ldots \ldots$ & \\
\hline & \\
\hline teristics 0 & \\
\hline
\end{tabular}

Babcock test $\ldots \ldots \ldots \ldots \ldots \ldots$. 135.5 apparatus for .........137 method of making.......140 method of reading.......141 pointers on making......142 principle of $\ldots \ldots \ldots \ldots \ldots \ldots$ sample for ...........135

Babcock testers ............136 Bacteria, discussion of.......146 Barn, dairy ............ 86 Barn yard, clean...........157 Barrenness .................119 Bedding for cors...........162 Bitter fermentation ..........151

Bloat ............................

Bloody milk ................120

Breeding, purity of ........ 14

Breeding rack ............ 77

Building up herd .......... 20

Bull, selection of $\ldots . \ldots \ldots 17$ feeding of $\ldots \ldots \ldots \ldots \ldots 74$ management of ........74 pedigree of $\ldots \ldots \ldots \ldots \ldots 17$ pen $\ldots \ldots \ldots \ldots \ldots \ldots \ldots .75$
Bu11, prepotency of ....... 18

type of $\ldots \ldots \ldots \ldots \ldots \ldots \ldots \ldots \ldots \ldots$ 1s

valuing of $\ldots \ldots \ldots \ldots \ldots 251$

Butter boxes .............. 199

cartons ..............186

composition of ........186

marketing of .........186

salting of .............

working of ...........1s3

Buttermilk, feeding value ....281

Buttermilk, skimmilk ........233

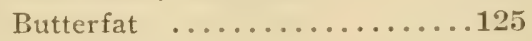

composition of .........126

method of estimating ....6 60

physical properties of ....125

production .......... 11

testing for ........... 135

Buttermaking ........... 16.5

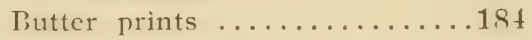

Butter, working of .........183

Butyric fermentation ........150

Calf, care of ............ 85

prenatal development of... 82

rearing ............ 82

scours ..............115

stanchions $\ldots \ldots \ldots \ldots \ldots 8$.

Calves, feeding of ........ 83

selection of ...........23

valuing of $\ldots \ldots \ldots \ldots 250$

weaning of $\ldots \ldots \ldots \ldots \ldots 82$

Carbohydrates ............. 34

Cattle, breeds of dairy....... 25

Certified milk .............236

Checse, amount of color in....187 amount of rennet in......1S7 composition of ..........192 curing .............192 


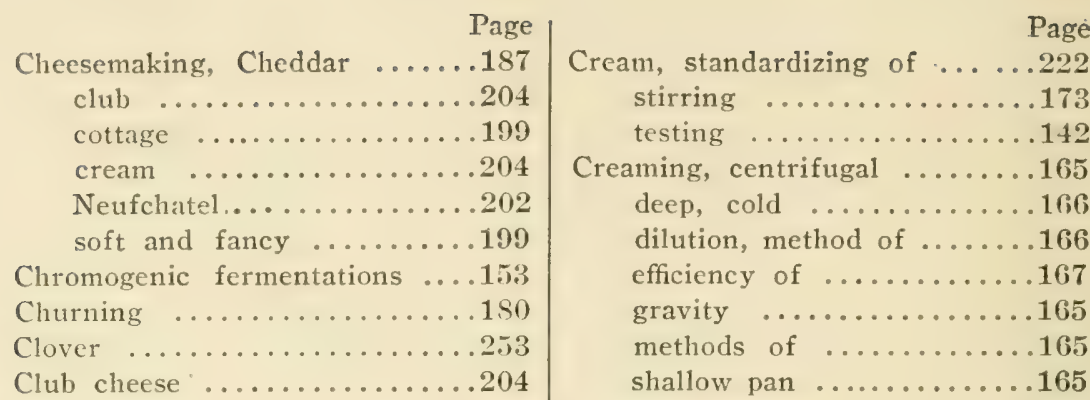

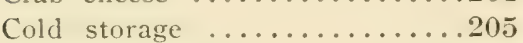

Colostrum milk ...........130

Composite sample jar ......663

Conformation of cows........11 of bulls ............. 18

Cooley can .......................

Corn for silage ........... 52

when to cut .......... 56

Cottage cheese ............199

Cow, dairy, points of ...... 12

Cows stalls and ties ........ 89

Cows, buying .............24

clean .................157

drying off $\ldots \ldots \ldots \ldots \ldots 79$

evolution of...$\ldots \ldots \ldots .9$

feeding of ............ 33

gestation period of.......287

health of $\ldots \ldots \ldots \ldots \ldots 16$

management of ....... 73

milk organs of $\ldots \ldots \ldots \ldots 13$

points of .......... 12

selection of $\ldots \ldots \ldots \ldots \ldots 12$

type of $\ldots \ldots \ldots \ldots \ldots \ldots 11$

valuing $\ldots \ldots \ldots \ldots \ldots 244$

Cream bottle ..............195

Cream, churnability of.......171

churning, temp. of .....172

composition of .......289

cooling ..............205

frothing of $\ldots \ldots \ldots \ldots \ldots 171$

marketing of $\ldots \ldots \ldots \ldots 217$

pasteurizing of $\ldots \ldots \ldots 284$

reading test of .........144

ripening $\ldots \ldots \ldots \ldots \ldots \ldots \ldots$

scales ...............140

separators .............. 167

shipping ............224

Curdling fermentation ........149

Dairy barn .............. 86

cross-section of ........100

ground plan for ....... 87

method of constructing ....88

ventilation of $\ldots \ldots \ldots \ldots 96$

Dairy by-products ..........280

Dairy calf, rearing of....... 82

Dairy cattle associations......287

Dairy herd, building up of.... 20

starting of ........... 22

Dairy houses ............256

Dairy rations .........37, 288

Dairy temperament ......... 12

Dairy type ............. 11

Dairying, direct profits in.... 7 indirect profits in ...... 8 winter ............. 73

Dehorning ............... 80

Diseases of cattle ...........110

Disinfectants ..............111

Dry matter, definition of ..... 34

Essutcheon ...............14

Ether extract ...............34

Farm buttermaking ..........165

Farrington acid test .........175

apparatus for ..........175

method of making .......176

Fats insoluble .............127 soluble ..............128

Feed, estimating cost of .....66 66

Feeding calves ........... 83

Feeding cows ............ 33

according to flow .......45 


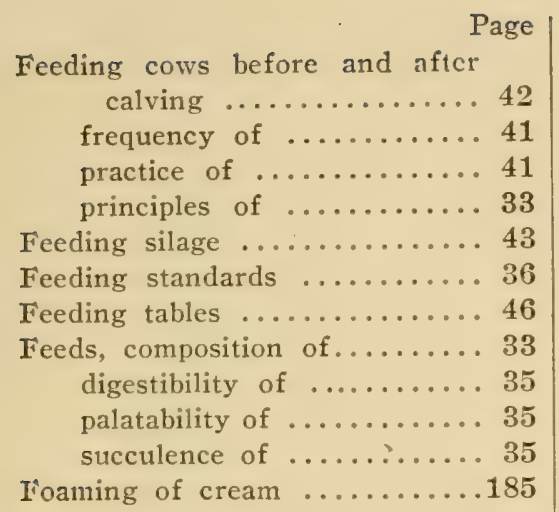

Garget .................114

Gasoline engine ............107

Gassy fermentation ..........152

Gestation, period of .......287

Glassware for Babcock test....136

Grubs ..................121

Guernsey cattle ............ 27 cliaracteristics of .......28

Gutters for barn .......... 95

Hand separators ...........167

Hay loft .............. 97

Health of cows .......... 16

Heat, frequency of . . . . . . 287

Heifers, age to breed ...... 78

Herd management .......... 73

Herd records ............6 60

Holstein-Friesian cattle ....... 29 characteristics of ........ 30

Hoven ...................119

Ice cream making ..........228

Ice house ..............277

Ice supply $\ldots \ldots \ldots \ldots \ldots \ldots 276$

Indigestion $\ldots \ldots \ldots \ldots \ldots \ldots \ldots$

Inversion of womb .......117

Jersey cattle ............ 25

characteristics of $\ldots \ldots \ldots 26$

Judging butter ...........288

Judging cheese ..........288

King ventilator
Lactic fermentation .........148

Legumes ...............253

Lice, treatment for..........121

Mangers ............... 94

Nanure ..................101

carrier ...............104

fermentation of $\ldots \ldots \ldots 103$

leaching of ...........102

losses in .............102

Marketing milk and cream.....217

Markets ................213

Metric system ...........287

Milk and its products .......239

relative value of $\ldots \ldots \ldots 239$

Milk, colostrum ...........130

bottle ...............195

certified ...........236

cooling .............205

creaming of ..........165

fever ...............112

fermentations .........146

houses .............256

keeping account of ......269

marketing of ..........217

organs ............. 13

pail, sanitary ..........159

pasteurization of ......284

physical properties of .....123

quality of ............132

record sheet ..........6 62

records ............6 60

room, sanitary ..........164

sanitary ..............155

scales ..............6. 61

secretion .............130

shipping .............224

standardizing .........222

straining of $\ldots \ldots \ldots \ldots 160$

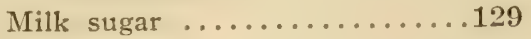

testing .............135

vessels ..............158

wells ............. 12

Milkers, value of good....... 71

effect of change of......69 69

clean ...............158 


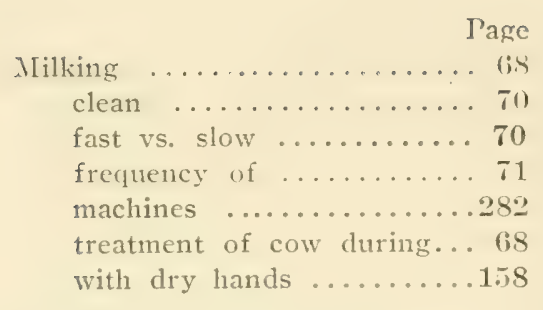

Neufchatel cheese making . . . :202 Nutritive ratio ............

Palatability of feeds ....... 35

Pasteurization ............284

Pedigree ................ 15

Pelvic region ........... 13

Power on farm ............106 possibilities for ........107

Prepotency defined .......... 18

Principle of Babcock test .....135

Principles of feeding ........ 33

Protein, definition of .......34

Purgatives ................111

Purity of breeding ......... 14

Quality of milk, variations in..132 Quarantining .............110

Ratio, nutritive ........... 39

Ration, definition of ........ 38

Rations, method of calculating.. 38 standard ................37

Ropy fermentation .........152

Salt for stock ............ 44

Salting butter .............182

Samplers, milk ..........64

Sampling milk ........... 64

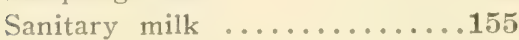

Scales, milk .............61 61

Secretion of milk .........130

Selection of cows .......... 11

Selection of sires ......... 17

Self-sucking cows ..........121
Page

Shallow pan creaming .......165

Skimmilk-buttermilk .........233

Skimmilk, feeding value of....2SO

Silos .................. 52

advantages of twin......57

capacity of ..........289

concrete ............. 55

concrete lined .........58 58

construction of ........54

cutting corn for .......59a

filling of $\ldots \ldots \ldots \ldots \ldots 59 \mathrm{~b}$

location of .......... 54

Michels' twin .......... 57

size of $\ldots \ldots \ldots \ldots \ldots \ldots 53$

Slimy fermentation .........152

Stalls ................. 89

Stalls, size of ........... 94

Standardizing milk and cream..222

formulas for ..........222

Starters ............................

Sterilizing vessels ........263

Sterilizers ......266, 267, 268

Stringy milk .............120

Teat troubles ..............120

Technical terms, definition of...290

Thermometer, dairy .........179

Test bottles ..............138

Testing .................... 135

Toxic fermentation ..........153

Tuberculin test .............117

Tuberculosis ..............117

Urine, saving of .........101

Ventilation of barn ........96

Ventilation, King system ..... 95

Warbles .................. 121

Washing vessels ...........263

Water for stock .......... 44

Water heater ..............265

Water supply ............274 


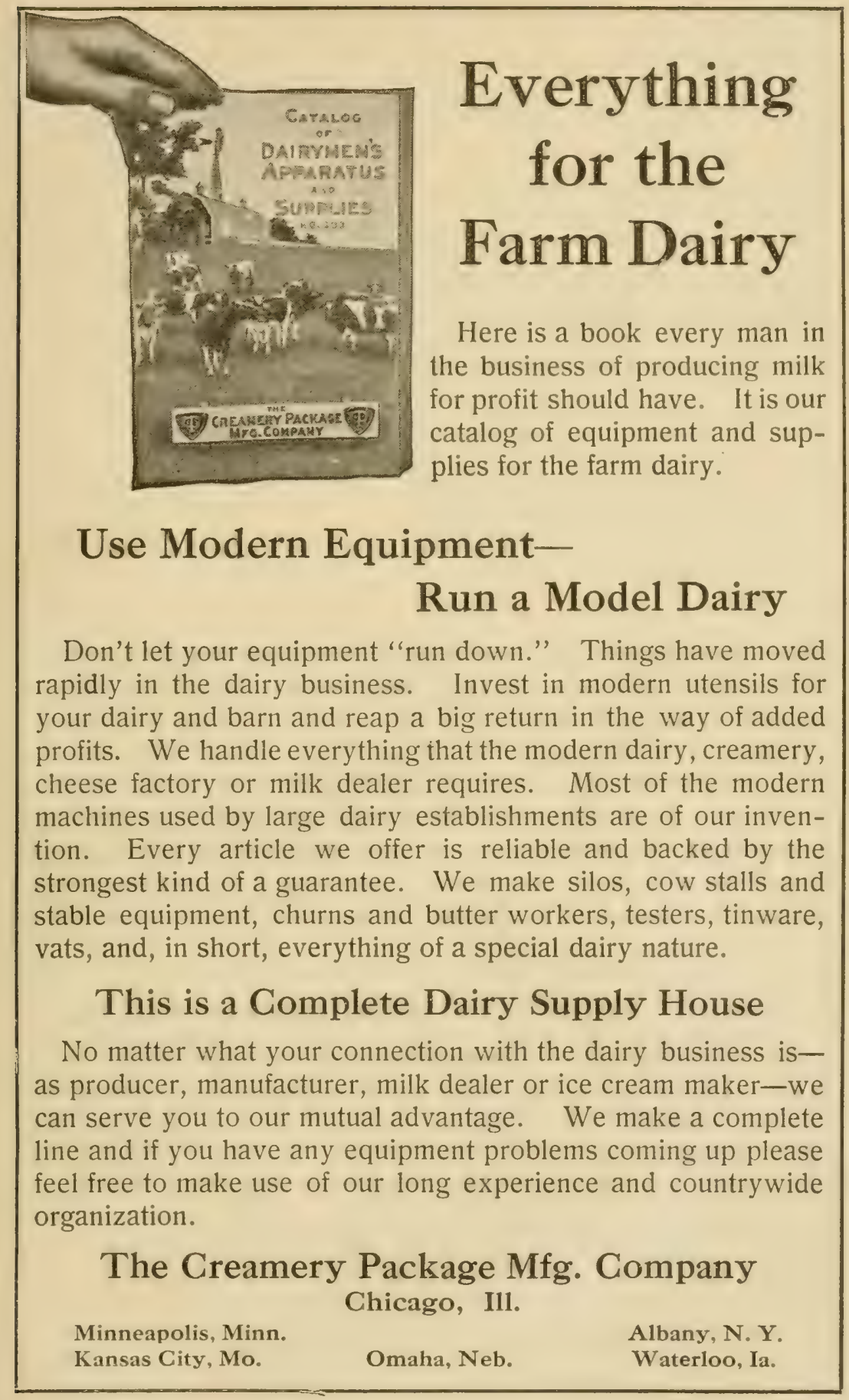




\section{Dairy Cleanliness Made Easy}

Dairy Cleanliness is no longer a theory, but a necessity. And the only question is how best may it be accomplished. Dairy and Agricultural Colleges, Creameries, Cheese Factories and Large Dairymen almost without exception are using

\section{Wyandotte \\ Dairyman's Cleaner \& Cleanser}

Its use does not end here, but the list includes thousands of small dairies, milk men and farmers. With such endorsement it is easy to determine that Wyandotte Dairyman's Cleaner \& Cleanser is the right article for the dairy trade.

Do you use it, and know because you have tried it how much real cleaning, how much sweetening of sour places and how freshening of staleness it does for you? Or is it to

Indian in Circle

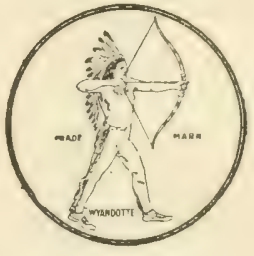

In every Package you a new article? If the latter, can you afford to leave it to others to have these advantages while you work harder trying to use some other cleaning material? Ask your dealer for a small sack of this cleaner, or for larger quantities, kegs or barrels, order from your dairy supply house.

\section{The J. B. Ford Company sole Mfrs. Wyandotte, Mich., U. S. A.}

This Cleaner has been Awarded the Highest Prize Wherever Exhibited 


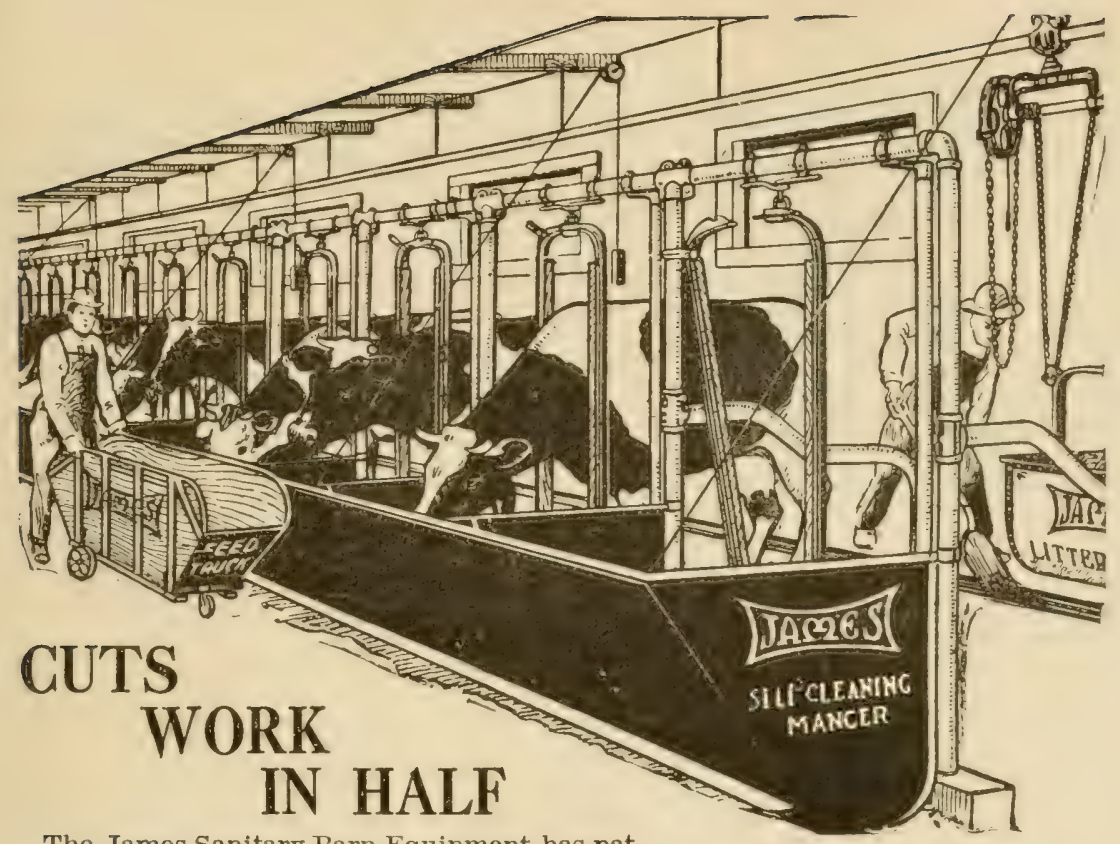

The James Sanitary Barn Equipment has patented features that reduce barn expenses by eut-

ting squarely in two the labor and time required in cleaning stalls and caring for the cows. And in addition to cutting the work in half, the cleaner stalls and barn possi. ble with Jimes Sanitary Barn Equipment increase the yield and improve the quality of the milk. 'This equipment is designed expressly to meet the needs of businesslike dairy farmers.

\section{JAMES SANITARY BARN EQUIPMENT}

The five patented features of the James Sanitary Barn Equipment save enough on feed and labor to pay for the whole equipment in a year.

\section{Is A Money Maker}

After this equipment has paid for itself the first year, it makes money by saving for you every year thereafter.

\section{Five Patented Features}

The Alignment Device lines up short, long and medium cows evenly on the gutter; the stall and cow are kept clean. Greatest improvement ever made on stanchions.

\section{Guarantee}

We guarantee everything we make to the fullest extent. Money refunded if the test in your barn does not prove the truth of all our claims.

Two Valuable Books Free

If you are interested in Stalls, Stan-
The Sure Stop Swinging Post prevents the cow putting her head into the wrong place.

The Lock Open Derice, together with the Sure Stop, when in position, forces the cow to put her head into stanchion; saves time and trouble.

The Double Chain Hanger makes possible a high level curb, thus preventing waste of feed; saves labor and material in building.

The Self Cleaning Manger enables you to feed cows according to their individ. ual need; prevents waste of feed and lessens labor. It is made without a bottom, and when raised trough can be swept and used for watering.

chions, Bull Pens, and Calf Pens or Box Stalls, ask for Book No. 8 . If you want information about Litter, Feed or Milk Can Carriers or Feed Trucks, ask for book entitled "Barn Work Made Easy." Ask for either one or both of these free books and state number of cows owned.

\section{KENT MFG. CO. 3420 Cane St., Fort Atkinson, Wis.}




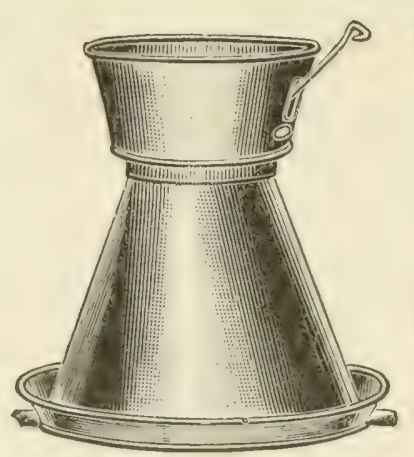

\section{The Champion} Milk Cooler

Used and Recommended by Leading Dairy Authorities

A high quality cooler at a very low pricewithin reach of all. Can be used with and without running water; also with ice. It is as easy to clean as a milk pail, and will do the work as well as the most expensive coolers. Save money by insisting on the GENUINE CHAMPION

\section{The Champion Sanitary} Milk Pail

This pail is the TRUMAN or LOY type. The simplest and best. Price . . . $\$ 1.50$

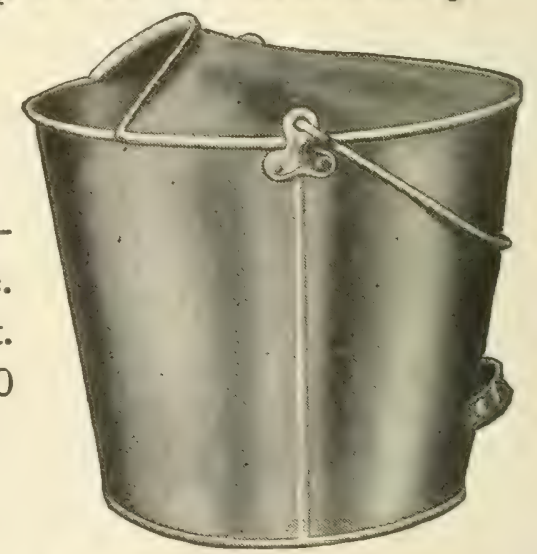

The Champion Milk Cooler Co. Box M, Cortland, New York 

DEC 26 1979) 
One copy del. to Cat. Div.

DEC $29 \quad 1917$ 


\section{LIBRARY OF CONGRESS \\ |||||||||||||||||||||||||||||||||||||||||||||||||||||||

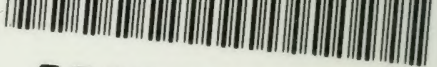 00008951421}

